VAGNER GODÓI

FUNCIONAMENTO DA OBRA DE PESQUISA 

VAGNER GODÓI

\section{Funcionamento da obra de pesquisa}

Tese apresentada ao Programa de PósGraduação Interunidades em Estética e História da Arte da Universidade de São Paulo para obtenção do título de Doutor em História da Arte.

Linha de Pesquisa: Teoria e Crítica de Arte

Orientadora: Prof. ${ }^{\text {a }}$ Dra. Lisbeth Ruth Rebollo Gonçalves

São Paulo 2018 
Autorizo a reprodução e divulgação total ou parcial deste trabalho, por qualquer meio convencional ou eletrônico, para fins de estudo e pesquisa, desde que citada a fonte.

Catalogação na Publicação

Serviço de Biblioteca e Documentação

Faculdade de Filosofia, Letras e Ciências Humanas da Universidade de São Paulo

G577f

Godói, Vagner

Funcionamento da obra de pesquisa / Vagner Godói ;

orientador Lisbeth Ruth Rebollo Gonçalves. - São

Paulo, 2018.

$326 \mathrm{f}$.

Tese (Doutorado) - Programa de Pós-Graduação Interunidades em Estética e História da Arte da Universidade de São Paulo. Área de concentração: Estética e História da Arte.

1. Arte contemporânea. 2. pesquisa artística. 3 . escritos de artistas. 4. transdisciplinaridade. 5. arte brasileira. I. Rebollo Gonçalves, Lisbeth Ruth, orient. II. Título. 


AGRADECIMENTOS: À minha orientadora, Lisbeth Rebollo, que vem acompanhando meu desenvolvimento como pesquisador de modo preciso e gentil. Aos artistas Jorge Menna Barreto e Ricardo Basbaum, pelas conversas e o aprendizado na pesquisa. À Regina Silveira, por mostrar exatamente o que é pesquisa artística. Aos participantes da banca de qualificação, Ana Maria Tavares e Cayo Honorato, por propiciar desvio e sentido. Aos artistas Bia Medeiros, Gilbertto Prado, Hélio Fervenza, José Spaniol, Livia Flores, Mabe Bethônico, Milton Machado, Milton Sogabe, Raquel Stolf e Sylvia Furegatti, pela gentileza e as importantes contribuições. Aos professores e funcionários do PGEHA e do MAC USP. À Cristina Freire, Lauci Bortoluci, Anderson Tobita e Sara Valbon, pelo apoio. À Profa. Daisy Peccinini e Claudia Fazzolari pela confiança. À Marina Macambyra, pela ajuda com as teses de artistas. Ao Daniel Escobar e Fred Paulino, pela ajuda com re-projetando. À Tereza Gouveia, pela leitura atenta. Aos professores do IED pelo incentivo e a amizade: Eliane Weizmann, Paula Perissinoto, Mari Pini, Débora Caramaschi, Lucila Meirelles,

Rodrigo Silveira, Lívia Gabbai, Andrei Thomaz, Sérgio Gregório e Bruno Pompeu. Aos amigos Lúcio, Susana, Rodrigo, Rudi, Carlos, Florence, Luci, Bettina, Enio, Nikolaus, Guido, Lívia e Laila que acompanham essa história. Aos meus pais Ana Lúcia e Vicente, minhas irmãs Paula, Adriana e Vânia e meus sobrinhos Nina, Guiga, Lili, Leo, AL e JF.

À Lia ... S2 



\section{Resumo/ Funcionamento da obra de pesquisa}

Entre os anos 2000 e 2010, são intensificadas e renovadas mundialmente as discussões sobre produções artísticas que se relacionam com o conhecimento, a universidade, a pesquisa, a teoria, a reflexão, a educação e os outros campos do conhecimento. Um dos ângulos desse fenômeno multifacetado, e que é motivo de interesse crescente dos artistas e demais profissionais da Arte, pode ser resumido com a expressão pesquisa artística. Uma das contribuições desta tese é relacionar o pioneirismo da criação dos programas de pós-graduação em Artes Visuais no Brasil, com trajetória consistente de estabelecimento e definição desde a década de 1970, a esse fenômeno recente, que aconteceu sobretudo na Europa, disparado pela transformação das academias de arte em universidades por lá, seguida de um debate intenso sobre os significados da pesquisa do artista. Além disso, este estudo percorre as produções artísticas, discursivas, pedagógicas e teóricas dos artistas brasileiros Jorge Menna Barreto e Ricardo Basbaum em busca da linha poética da pesquisa, contextualizando-os tanto como herdeiros da pesquisa em arte no Brasil quanto associados a essa movimentação internacional sobre a pesquisa artística. Parte-se da incerteza sobre a multiplicidade dos significados e das nomenclaturas que a pesquisa do artista provoca, não como uma indagação ontológica, mas com o propósito de entendimento sobre o seu lugar, uma questão institucional da arte inserida no ambiente universitário e, sobretudo, um problema que se encontra na própria obra de arte, agora considerada de pesquisa.

PALAVRAS-CHAVE: Arte contemporânea; pesquisa artística; escritos de artistas; transdisciplinaridade; arte brasileira. 



\section{Abstract/ Functioning of the work of research}

From the years 2000 to 2010 , discussions on artistic productions that are related to knowledge, university, research, theory, reflection, education and other fields of knowledge are intensified and renovated. One of the angles of this multifaceted phenomenon, and a reason for the rising interest in it by artists and other art professionals, can be summarized by the expression artistic research. One of the contributions of this thesis is correlating the pioneering creation of postgraduate programs in Visual Arts in Brazil, consistently established and defined since the 1970s, to this recent phenomenon, that took place specially in Europe, initiated by the transformation of art academies into universities, followed by an intense debate on the meanings of artist research. Moreover, this study examines artistic, discursive, pedagogical and theoretical productions by Brazilian artists Jorge Menna Barreto and Ricardo Basbaum in order to find the poetic line of research, contextualizing both as heirs of research in art in Brazil and affiliates of these international shifts on artistic research. The starting point is the uncertainty regarding the multiplicity of meanings and nomenclatures that artist research provokes, not as an ontological enquiry, but with the purpose of understanding their place, an institutional matter of art inserted in the university environment, and, particularly, a problem found in the work of art itself, now considered research.

KEYWORDS: contemporary art; artistic research; artists' writings; transdisciplinarity; Brazilian art 



\section{Índice}

Introdução: a obra de arte e a pesquisa................................................................15

$\rightarrow$ Capítulo 1 - Pesquisa do artista na universidade brasileira.............................39

$\rightarrow$ Capítulo 2 - Projeto Matéria (de ensino e pesquisa).........................................61

$\rightarrow$ Capítulo 3 - Os estados da pesquisa artística...................................................103

$\rightarrow$ Capítulo 4 - Você gostaria de participar de uma

experiência (pesquisa) artística?............................................................................173

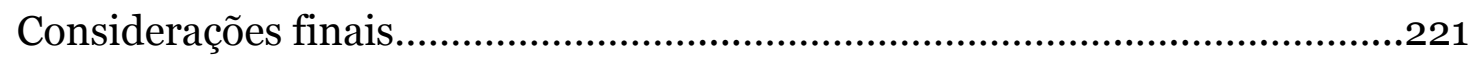

* Anexo 1 - Artistas-pesquisadores sobre

a pesquisa do artista na universidade................................................................23

* Anexo 2 - RB sobre a pesquisa artística:

na universidade, em vários circuitos, associada a outros campos.

* Anexo 3 - JMB sobre restauro agroecológico, amizade e pesquisa artística. 

INTRODUÇĀO:

A OBRA DE

ARTE E A

PESQUISA 



\section{JMB, RB e a pesquisa do artista no Brasil}

JMB e RB ${ }^{1}$ ilustram a conexão entre universidade e os mais variados circuitos da arte através da pesquisa, também em conexão com vários outros artistas que escrevem, fazem pesquisas, dão aulas, trabalham em várias frentes discursivas. Nesta tese, a matéria de JMB é uma matéria de pesquisa artística e a experiência de RB é uma experiência de pesquisa artística. Esses artistas foram escolhidos para se aproximar desta tese porque são artistaspesquisadores, têm um corpo teórico consistente de textos, incluindo dissertação e tese, são professores da universidade pública, se engajam em publicações, congressos, orientações, aulas, atividades administrativas etc. Além disso, trabalham de forma independente, fora do circuito acadêmico. Eles também são importantes para esta tese porque, no Brasil, são os artistas que mais se aproximam daquilo que se mostrou necessário desenvolver aqui, a ideia de pesquisa artística que circula em vários circuitos, que se encontra na obra de arte orientada à pesquisa, que se associa a outros campos do conhecimento.

Foram escolhidas duas obras exemplares desses dois artistas brasileiros que orientarão as discussões colocadas aqui e ajudarão a esclarecer algumas questões em torno das pesquisas feitas por eles. Enquanto Projeto Matéria, de $\mathrm{JMB}$, ajuda a fazer a passagem do artista-professor para o artista-pesquisador, Você gostaria de participar de uma experiência artística?, de $\mathrm{RB}$, ajuda a realizar a passagem da pesquisa artística na universidade para os mais variados

\footnotetext{
${ }^{1}$ São utilizadas as siglas JMB para Jorge Menna Barreto e RB para Ricardo Basbaum, utilizando a grafia da sigla sem pontos. Além de dar fluidez ao texto e facilitar o uso frequente dos nomes, essa estratégia tem conexão com o apreço pelas siglas mantido sobretudo por RB, mas também por JMB, pelo modo como os artistas nomeiam algumas de suas obras e conceitos: NBP (Novas Bases para a Personalidade) e MTST (Minha Terra Sua Terra) são alguns exemplos. Pode-se pensar na abreviação CsO para o conceito de "Corpo sem Órgãos", utilizado por Deleuze e Guattari no livro Mil platôs: capitalismo e esquizofrenia. Também no modo como Hélio Oiticica abrevia o nome de suas obras de arte ou séries, como em NC (Núcleo), P (Parangolé), CC (Cosmococa), B (Bólide) etc. Ou ainda ao modo como o poeta francês Charles Baudelaire utiliza durante todo o texto "O pintor da vida moderna" a sigla C. G. ao se referir ao pintor Constantin Guys, para preservar-lhe a identidade ou, antes, fazer uma diluição da autoria através das ideias de multidão e obra de um anônimo. "Enamorado pela multidão e pelo incógnito, C. G. leva a originalidade às raias da modéstia. (...) Ainda recentemente, quando soube que eu me propunha fazer uma apreciação de seu espírito e talento, suplicou-me, de uma maneira muito imperiosa, que seu nome fosse suprimido e que só falasse das obras como obras de um anônimo". Charles Baudelaire, Sobre a modernidade/ O pintor da vida moderna, 1996, p. 14.
} 
circuitos artísticos, temas principais do Capítulo 2 e do Capítulo 4, respectivamente. Outras obras recentes desses artistas também vão compor a imagem da pesquisa artística que se pretende traçada aqui, pois além de se moverem por vários circuitos, essas obras apropriam-se de outros campos do conhecimento ou se associam a eles. Restauro, de JMB, por exemplo, faz uma pesquisa específica sobre a agrofloresta e a alimentação, de forma aberta e não logocêntrica. Re-projetando e conversas-coletivas, de RB, são obras que podem disparar diversas pesquisas artísticas transdisciplinares. Os projetos poéticos de JMB e RB apresentam uma dimensão de pesquisa discursiva, desenvolvem um tipo específico de pesquisa que se dá através da conversa e do discurso, do texto e da teoria. Além disso, são exemplos emblemáticos de pesquisa que acontece a partir da universidade, porque tanto Projeto Matéria quanto Você gostaria...? são trabalhos em processos colaborativos e participativos com comunidades acadêmicas e artísticas, que são chamadas a participar de suas obras.

JMB, atualmente professor do Instituto de Artes da Universidade do Estado do Rio de Janeiro (Uerj), possui uma trajetória artística atrelada aos questionamentos atuais sobre processos pedagógicos e processos de pesquisa no limite com a criação artística. Sua dissertação Lugares moles, de 2008, em torno da ideia de site-specificity, e a tese Exercícios de leitoria, de 2012, sobre leitura e transformação de projetos poéticos de outros artistas, desenvolvem ideias e teorias importantes para a discussão que vai ser desenvolvida nesta tese, como: a pesquisa artística e o papel do artista que se relaciona com o meio acadêmico; o escrito de artista considerado obra de arte; a criação de metodologias específicas para a pesquisa do artista, dentro e fora da universidade; a ampliação do conceito de site-specificity da condição de lugar para lugar discursivo; a aproximação de questões sociais e políticas; a fragmentação e o espalhamento do que é uma obra de arte, que passa a ter tempos e espaços dilatados, que se conectam entre si; os novos modos de a arte situar-se no mundo e com o público.

Em RB, os conceitos e a teoria são inseparáveis da produção artística, e esse é um dos seus posicionamentos mais fortes, que pode ser compreendido através da ideia de artista-etc., uma nova imagem para o artista, que agora se 
desdobra em vários circuitos da arte, como curador, pesquisador, editor, crítico, teórico, agenciador, professor etc. O projeto Você gostaria de participar de uma experiência artística? foi muito importante para as discussões da documenta 12, principalmente sobre os processos educacionais e de pesquisa. Sua tese de doutorado, parte desse projeto, defendida na área de concentração "Poéticas Visuais" da ECA-USP em 2008, explica a participação do público, a relação do artista com vários circuitos e instituições de arte, a relação entre imagem e palavra, e também uma ideia muito importante para a presente tese, que é a de teoria do artista, um procedimento de trabalho que coloca a teoria e a pesquisa como materiais, ferramentas, estratégias e métodos principais do artista contemporâneo. A pesquisa artística é um processo de longa duração, têm um funcionamento que se desdobra no tempo, e resulta na criação de muitos conceitos de artista, que se espalham por um sistema complexo composto de várias partes, como objetos, diagramas, ideias, conversas etc.

Em muitos momentos desta tese, vai ser utilizado um método de leitura que se dá a partir da descrição ${ }^{2}$ do funcionamento das obras de arte. Também deve ser mencionado que a escolha da linha poética da pesquisa não deve impedir o cruzamento com outras linhas. JMB e RB servem de apoio para que um novo entendimento sobre a pesquisa artística possa ser esboçado, uma pesquisa que não se esgota na institucionalidade da academia, mas que se encontra na poética dos artistas. Esta problemática, entre outras questões, foi colocada aos dois artistas nas conversas estabelecidas com cada um, que se encontram no Anexo 2 (RB) e no Anexo 3 (JMB) desta tese.

As décadas de 2000 e 2010 são muito importantes para esses artistas, pois suas obras e seus pensamentos estão conectados com vários outros artistas e pensadores desse período, com os quais compartilham as linhas que atravessam a arte e os temas mais urgentes de agora. A complexidade de suas obras não se esgota na linha poética da pesquisa, ou do conhecimento, ou da educação, somente. Esses artistas darão suporte para algumas reflexões que

\footnotetext{
${ }^{2}$ Segundo Bruno Latour, para a teoria do ator-rede, pesquisar tem mais relação com a descrição do que com a explicação, onde atores e objetos de estudo devem "expressar por si mesmos". Ao pesquisador cabe fazer a descrição da melhor forma possível. Ver: Bruno Latour, Como terminar uma tese de sociologia, 2006.
} 
serão colocadas aqui, em torno da pesquisa artística, porém já se deve fazer o alerta de que a leitura proposta não encerra a discussão ou delimita uma única visão sobre o projeto poético desses artistas, que são construídos de forma complexa, distribuída e fragmentada. Entre as perguntas principais a fazer, estão: Como funcionam essas obras de pesquisa? Como a pesquisa funciona nos projeto poéticos de JMB e de RB?

As discussões pioneiras em torno da pesquisa artística ou pesquisa em arte no Brasil vêm ocorrendo de forma crescente desde que um programa de pós-graduação em Arte foi criado na Escola de Comunicações e Artes da Universidade de São Paulo (ECA-USP) nos anos 1970, lugar onde JMB desenvolveu tanto mestrado quanto doutorado, e onde RB desenvolveu seu doutorado. As relações entre Arte e Ciência, porém, já vinham ocorrendo por aqui há mais tempo, inaugurada de forma contemporânea pela Poesia Concreta $^{3}$, numa tradição que influenciará, dentro das universidades brasileiras, as discussões sobre a produção artística que se dá a partir do meios tecnológicos, sobretudo a partir dos anos 1980, conforme mais artistas se aproximam da universidade como pesquisadores. A diversidade, complexidade e consistência da pesquisa em arte no Brasil, realizada em várias universidades públicas que contemplam esse tipo de pesquisa, reconhecida pelas agências de avaliação e de fomento, assunto que será tratado no Capítulo 1, são resultado dos esforços de muitos artistas e pesquisadores da Arte que, de forma espontânea e ao mesmo tempo combativa, criaram uma das primeiras experiências consistentes e duradouras de pesquisa do artista em universidades.

\section{Fenômeno da pesquisa artística}

A pesquisa artística é menos uma novidade do que um fenômeno que se intensifica nos últimos tempos. Fora do Brasil, os debates aumentaram a partir dos anos 2000, por conta da transformação ou integração das academias de arte europeias em universidades, em um processo que aconteceu disparado pela Declaração de Bolonha, onde foi acertado que os países integrantes da União

3 Ver: Haroldo de Campos, Depoimento sobre arte e tecnologia, 1997. 
Europeia iriam padronizar seus sistemas de ensino. Como consequência desse processo de reformas do ensino superior, começou uma movimentação em várias academias e escolas de arte para que um dos elementos ou atividades fundamentais da universidade, que é a pesquisa, se tornasse uma das novas atribuições do artista-professor e também dos alunos de Artes, que agora tinham mais titulações a alcançar. As academias e escolas de arte tiveram que se reinventar, objetivando e construindo programas de pós-graduação que conferissem títulos de doutorado, de modo a equiparar-se com as outras áreas acadêmicas. Assim, o desenvolvimento de um ambiente propício de pesquisa para os artistas apresenta motivações institucionais claras de obtenção de financiamento e auxílios, para que os artistas possam manter-se em um lugar próprio, ainda que dentro de regras e protocolos, assumindo também novos compromissos e se adaptando ao novo ambiente ou circuito.

Henk Slager, professor na Universidade de Artes de Utrecht, um dos responsáveis da criação do programa de pós-graduação em Arte por lá, é uma das figuras importantes da pesquisa artística na Europa e uma das pessoas que ajudou a animar os debates em torno desse assunto, organizando encontros, livros e exposições. Em 2004, com Annette Balkema, organizou "Artistic Research”, um dos primeiros encontros dentro dessa nova movimentação, e que resultou em uma coletânea, também pioneira nesse contexto4. É editor de publicações importantes como MaHKUzine, com números editados entre 2007 e 2011, e MaHKUscript, que vem sendo publicada desde 2016. Slager desenvolveu projetos curatoriais que levam em conta a pesquisa do artista de um modo mais amplo, como na $7^{\mathrm{a}}$ Bienal de Xangai, de 2008, da qual foi um dos cocuradores, quando organizou a pequena exposição Nameless Science, no apexart de Nova York, em 2009, ou como curador da exposição Artistic Anthropology exibida no Nam June Paik Art Center de Seul, em 2010, todas contando com a participação de RB. Slager também esteve à frente do evento paralelo à Bienal de Veneza, chamado Becoming Bologna, em 2009, do projeto formado por exposição e conferência para a Manifesta 8 em Múrcia chamado As the Academy Turns, em 2010, do pavilhão holandês da $9^{\text {a }}$ Bienal de Xangai,

\footnotetext{
4 Annette Balkema e Henk Slager (eds.). Artistic Research, 2004.
} 
chamado Temporary Autonomous Research, em 2012, e foi cocurador da $1^{\mathrm{a}}$ Trienal de Tbilisi em 2012, na Geórgia, do projeto Aesthetic Jam, parte da Bienal de Taipei, em 2014, e do $1^{0}$ Pavilhão da Pesquisa, chamado Experimentality, uma exposição paralela à Bienal de Veneza, em 2015, entre outros. Ele criou em 2004 com Gertrud Sandqvist, da Academia de Arte de Malmö, Jan Kaila, da Academia de Belas Artes da Finlândia, e John Aiken, da Escola de Arte Slade, a Rede Europeia de Pesquisa Artística (EARN)5, uma associação cujo objetivo é fomentar simpósios e conferências, em eventos como Epistemic Encounters, realizado em Utrecht, 2009, Art as a Thinking Process, em Veneza, 2011, e Doing Research, em 2012, evento paralelo à dOCUMENTA (13). Vários eventos que ele coordenou ou em que esteve envolvido resultaram em coletâneas ${ }^{6}$ com textos fundamentais para se entender essa movimentação internacional da arte sobre a pesquisa. Essas coletâneas, ao lado de outras que também são importantes para o fenômeno7, são formadas por textos de artistas como RB, Hito Steyerl, Victor Burgin, Anton Vidokle, Falke Pisano, Liam Gillick, Marion von Osten, Sarah Pierce, Angela Melitopoulos, Nicoline van

5 Outras redes e associações criadas para promover a pesquisa artística na Europa são a Liga Europeia dos Institutos das Artes (ELIA), formada por várias faculdades e academias de arte e design, e a Sociedade de Pesquisa Artística (SAR) que, entre outras atividades, publica a revista online Journal for Artistic Research (JAR) e organiza a Conferência Internacional sobre Pesquisa Artística (SAR).

6 Entre as coletâneas de textos que estão relacionadas com os eventos propostos por Henk Slager ou apoiadas pelo EARN, estão: maHKUzine, $\mathrm{n}^{0} 7$, "Nameless Science" (edição da revista), 2009; maHKUzine, nº8, "Epistemic Encounters" (edição da revista), 2010; maHKUzine, n ${ }^{0} 10$, "As the Academy Turns" (edição da revista), 2011; Henk Slager (ed.), Temporary Autonomous Research (catálogo de exposição), 2012; Jan Kaila e Henk Slager, Doing Research, 2012; Mara Ambrozic e Angela Vettese (ed.), Art as a Thinking Process, 2013; Henk Slager (ed.), Experimental Aesthetics (catálogo de exposição), 2014.

7 Outras coletâneas importantes para o entendimento da pesquisa artística são: Kathrin Busch e Dieter Lesage (eds.), A Portrait of the Artist as Researcher (catálogo de exposição), 2007; Art \& Research, v. 2, $\mathrm{n}^{\mathrm{O}}{ }_{2}$, "A Gathering of Artistic Research: From New Science to Nameless Science" (edição da revista), 2009; Corina Caduff et al. (eds.), Art and Artistic Research, 2009; Texte zur Kunst, no82, "Artistic Research" (edição da revista), 2011; Janneke Wesseling (ed.). See It Again, Say It Again, 2011; Florian Dombois et al. (eds). Intellectual Birdhouse, 2012; James Elkins (ed.), Artists with PhDs, 2014; Michael Schwab e Henk Borgdorff (eds.), The Exposition of Artistic Research, 2014; José Quaresma e Fernando Rosa Dias, Investigação em artes, 2015. Também podem ser citadas as coletâneas editadas por Paul O’Neill e Mick Wilson, Curating Research, de 2015, cujo foco está na pesquisa artística e na exposição de pesquisa, e Curating and the Educational Turn, de 2010, que trouxe a palavra-chave "virada educacional", para tentar dar conta de projetos artísticos e curatoriais em relação com a educação e, de certa maneira também, como um modo de lidar com o interesse da Arte pelo conhecimento e que se orienta para a universidade e as escolas de arte. As relações da arte com a academia serão vistas em várias artigos e edições da revista e-flux, sobretudo nos números 3 e 4, de 2009. 
Harskamp, Mick Wilson, Stephan Dillemuth, Jan Svenungsson, por exemplo, e de autores como Tom Holert, James Elkins, Kathrin Busch, Irit Rogoff, Dieter Roelstraete, Sarat Maharaj, Chus Martínez, Simon Sheikh, Jonathan Lahey Dronsfield, Dieter Lesage, Mika Hannula, Daniel Birnbaum, Gertrud Sandqvist, nomes importantes da arte contemporânea que participaram desses debates e escreveram acerca da pesquisa artística, sobre a qual vários circuitos artísticos europeus se debruçaram, em questionamentos sobre a pesquisa feita pelo artista na universidade, bem como sobre a pesquisa que se encontra na obra de arte.

Com curadoria de Carolyn Christov-Bakargiev e realizada em 2012, a dOCUMENTA (13) teve como tópicos principais o conhecimento e a pesquisa, presentes na declaração da exposição e em algumas conferências realizadas em torno da mostra. De modo geral, todas as edições da documenta têm uma proximidade com o conhecimento e a teoria, em obras que estão às voltas com os debates mais urgentes de cada época, com uma propensão à política. Porém, desde a documenta X, de 1997, que teve a curadoria de Catherine David, há um engajamento maior com as publicações e as palestras, com a participação de pesquisadores e teóricos de várias áreas em debates e conversas, em plataformas e programas públicos. Nesse sentido, a dOCUMENTA (13) avançou sobre a ideia de plataformas da documenta 11, que por sua vez deu continuidade ao que tinha sido desenvolvido na documenta X, com o "100 Days - 100 Guests”, onde foram convidados a falar artistas, cientistas, filósofos, críticos, economistas, arquitetos, urbanistas, em cada um dos dias da duração da mostra. Porém, as discussões sobre os significados da pesquisa artística foram colocadas de forma mais programática na dOCUMENTA (13), seguindo os intensos debates que aconteceram da década de 2000 à de 2010.

Enquanto os artistas se aproximaram da pesquisa e da Ciência, trabalhando com palestras, conferências, encontros, diálogos, conversas e publicações dentro de seus projetos artísticos, pesquisadores de outras áreas e filósofos também se aproximam do campo da arte, propondo exposições que ficam entre o artístico e científico, tais como as exposições organizadas pelo sociólogo Bruno Latour, como Iconoclash - Beyond the Image Wars in Science, de 2002, em parceria com Peter Weibel e com a colaboração de Hans Ulrich 
Obrist, Hans Belting, entre outros, realizada no Centro de Arte e Mídia - ZKM, em Karlsruhe, em que foram colocados dispositivos tecnológicos e imagens religiosas ao lado de obras de diversas épocas. Houve ainda a exposição desenvolvida por Latour em 2016, Reset Modernity!, com Martin GuinardTerrin, Christophe Leclercq e Donato Ricci. Também podemos citar o filósofo Georges Didi-Huberman com a exposição Atlas, realizada em 2010, no museu Reina Sofía, ou a exposição Soulèvements, exibida primeiramente no museu do Jeu de Paume, em 2016 ${ }^{8}$. Essas exposições avançam sobre a exposição como “apresentação de ideias" proposta por Jean-François Lyotard na exposição Les Immatériaux no Centre Pompidou em 1985.

Nos últimos anos, curadores também começam a fazer exposições que proporcionam um ambiente onde a teoria e a pesquisa são desenvolvidas. Uma exposição conhecida por explorar as relações de transdisciplinaridade entre produção artística e pesquisa científica foi Laboratorium, organizada por Hans Ulrich Obrist e Barbara Vanderlinden, principalmente sobre as ideias de experimentação artística próxima da experimentação científica, em que artistas como Olafur Eliasson, Fia Backström, Simone Forti, Cerith Wyn Evans, Marina Abramovic, Pedro Reyes, Thomas Saraceno, Jonas Mekas, entre outros, propuseram várias ações na cidade de Antuérpia, em 1999, em várias experiências colaborativas com o público. Recentemente, algumas exposições e projetos curatoriais acompanharam o pensamento sobre a pesquisa artística, tais como o The Anthropocene Project, realizado em Berlim, em 2014, na Casa das Culturas do Mundo (HKW), desenvolvido por Anselm Franke em torno da ideia de exposição de pesquisa ou exposição-ensaio9. O autor desenvolve essa ideia para falar de exposições onde questões relevantes para a atualidade são discutidas de forma transdisciplinar por artistas e outros tipos de pesquisadores, sendo que os próprios artistas escolhidos também trabalham nessa nova percepção da arte como um ambiente de teoria e de pesquisa sobre os assuntos mais urgentes da nossa época.

8 Uma versão da mostra com o nome Levantes aconteceu em 2017 no Sesc Pinheiros, em São Paulo.

9 Ver: Bruno Latour e Anselm Franke, Angels Without Wings (Conversa), 2010; Anselm Franke 


\section{Desenvolvimento da pós-graduação brasileira}

No Brasil, as atividades de pesquisa ${ }^{10}$ incorporadas entre as funções da universidade começaram a tomar impulso entre o final dos anos 1940 e começo da década de 1950, a partir de uma série de iniciativas, pareceres e instituições de leis, com o intuito do estabelecimento, organização e promoção da pesquisa no país. É deste período a criação da Sociedade Brasileira para o Progresso da Ciência (SBPC) em 1948, do Conselho Nacional de Desenvolvimento Científico e Tecnológico (CNPq), em 1951, e da Coordenação de Aperfeiçoamento de Pessoal de Nível Superior (CAPES), também em 1951, tendo o educador Anísio Teixeira como secretário-geral da comissão responsável por sua implantação. A ideia de cursos de doutorado no Brasil surgiu com a reforma do ensino superior em 1931, coordenado por Francisco Campos, porém essa reforma privilegiava os doutorados como cursos para a formação de professores, e não deixava um posicionamento a respeito da pesquisa muito claro.

Em 1961 ocorreu a regulamentação da primeira Lei de Diretrizes e Bases da Educação Nacional, onde foram categorizados pela primeira vez os cursos de pós-graduação, distinguidos dos cursos de especialização e aperfeiçoamento, tendo a pesquisa como um dos seus objetivos principais. Os primeiros cursos contemplando tanto mestrado quanto doutorado começaram a funcionar no início da década de 1960 em iniciativas na Universidade Federal do Rio de Janeiro, na Escola Superior de Agricultura de Viçosa e no Instituto Tecnológico de Aeronáutica (ITA). A Universidade de Brasília (UnB), fundada em 1962, tendo Darcy Ribeiro e Anísio Teixeira como seus principais idealizadores, foi o primeiro projeto de universidade moderna no Brasil, onde a integração das atividades de ensino e pesquisa estavam instituídas pela primeira vez, com o objetivo de integrar a Ciência e Tecnologia às atividades da universidade.

10 Sobre o processo de institucionalização da pesquisa ao lado do ensino nas universidades brasileiras, ver: Newton Sucupira, Antecedentes e primórdios da pós-graduação, 1980; Cássio Miranda dos Santos, Tradições e contradições da pós-graduação no Brasil, 2003; Maria de Lourdes de Albuquerque Fávero, A Universidade no Brasil: das origens à Reforma Universitária de 1968, 2006; Ciência e cultura, "Núcleo Temático: Universidade na Ditadura”, 2014. 
Em 1965, segundo ano do regime militar que se estenderia ainda por vinte anos, ocorreram a definição e a implantação formal dos cursos de pósgraduação no Brasil, através do parecer CFE n $977 / 65$, que teve por relator Newton Sucupira, fato que permitiu o desenvolvimento e a expansão dos cursos de mestrado e doutorado pelo país. Esse processo de modernização da universidade realizada pelo regime militar, que tinha interesses desenvolvimentistas, mas que também era motivo de debates e lutas em vários campos da sociedade na época, da intelectualidade aos estudantes, culminou na Reforma Universitária de 1968, que teve Sucupira como uma de suas principais lideranças. Depois da reforma, a organização dos cursos se dava por uma estrutura de departamentos em vez do sistema de professor catedrático e foi estipulado que professores assistentes podiam ter o título de mestres, mas para se chegar ao cargo de professor adjunto, estes deveriam ter o título de doutor.

A pós-graduação foi um dos pilares da reforma universitária de 1968 e atuação do CNPq e da CAPES e proporcionou um crescimento expressivo entre as décadas de 1970 e 1980, acrescida da participação das associações de pesquisadores, que começavam a aumentar nas mais diversas áreas. A reforma de 1968 baseou-se, sobretudo, em modelos americanos, que por sua vez são adaptações do modelo germânico das "universidades de pesquisa", ideia de Wilhelm von Humboldt, onde pesquisa e ensino se dão de forma integrada, implantada como reforma educacional na então Prússia e aplicada pela primeira vez em 1810 com a fundação da Universidade de Berlim.

\section{Pesquisa}

Da metade do século 20 em diante, segundo Bruno Latour, inicia-se a transição da cultura da "ciência" para a cultura da "pesquisa", sendo a primeira feita de certezas e objetividades, e a segunda, de incertezas e controvérsias. Segundo o autor, o modelo e o significado da ciência não dão conta mais da época atual, e a palavra pesquisa representa melhor a aproximação com a sociedade em direção a uma ciência coletiva, ao experimento coletivo, em que a 
sociedade se vê envolvida nas questões resolvidas e levantadas pelas Ciências, e esta, por outro lado, se vê mais conectada com a sociedade ${ }^{11}$.

Uma das definições de pesquisa mais aceitas e utilizadas pelas universidades, empresas e governos de vários países vem do Manual Frascati, o qual vem sendo elaborado desde 1963 pela Organização para a Cooperação e Desenvolvimento Econômico (OECD), com o intuito de ajudar a avaliar a produção científica e tecnológica em relação aos investimentos realizados. O Manual define pesquisa e desenvolvimento (P\&D) como o trabalho criativo e sistematizado para o aumento do conhecimento, incluindo o conhecimento sobre a humanidade, a cultura e a sociedade, e que também resulta em novas maneiras de se aplicar o conhecimento, atendendo a critérios de criação de novos conhecimentos, originalidade e criatividade, incerteza, planejamento e sistematização, reprodução e transferência dos novos conhecimentos, caracterizando-se através de três tipos de atividades, que são a pesquisa básica, a pesquisa aplicada e o desenvolvimento experimental, este último direcionado a produzir novos produtos e processos. A produção artística não é considerada $\mathrm{P} \& \mathrm{D}$, isso porque a Arte, segundo o Manual, busca novas expressões e não novos conhecimentos ${ }^{12}$.

Henk Borgdorff, a esse respeito, faz um questionamento se a pesquisa artística poderia ser entendida como um tipo de pesquisa acadêmica e se esse tipo de pergunta já não revela, também, a falta de consenso sobre o que é a pesquisa acadêmica, sujeita a alterações conforme a época, crendo que a própria introdução da prática de pesquisa do artista na universidade é um ponto nesse processo de transformação constante ${ }^{13}$. Sarat Maharaj fala sobre a multiplicidade da ciência, que não é formatada por um único método e por um único modo de "rigor", pois é formada por variadas e divergentes atividades, disciplinas e domínios, cada um com suas lógicas e seus procedimentos, o que também se abre para a pluralidade de metodologias da pesquisa artística ${ }^{14}$.

\footnotetext{
${ }^{11}$ Bruno Latour, From the World of Science to the World of Research, 1998.

12 OECD, Frascati Manual 2015, pp. 44-45 e 65.

${ }_{13}$ Henk Borgdorff, Where Are We Today? The State of the Art in Artistic Research, 2012, pp. 120-121.

${ }_{14}$ Sarat Maharaj, Know-how and No-how, 2009.
} 
Arlindo Machado também alerta para a incompreensão da relação pesquisa e Arte, argumentado que a pesquisa não se dá da mesma maneira em todos os campos do conhecimento, seja na Medicina, na Matemática, na História da Arte ou simplesmente na Arte ${ }^{15}$.

Campo é um dos conceitos mais importantes elaborados pelo sociólogo francês Pierre Bourdieu, utilizado para estudar o modo como os agentes das mais diversas esferas se agrupam de forma autônoma e interagem entre si e com os outros campos. Aqui, são importantes os modos como são delimitados o campo artístico e o campo científico. Cada campo apresenta determinada autonomia em relação a outros campos, mas podem ser dependentes, como é o caso da dependência que pode ocorrer do campo econômico e do campo político. Campo é um conceito da ordem do político, um lugar de relações de força e resistência, na medida em que fala das disputas entre indivíduos, grupos e instituições interessadas em dominar a condução das regras de seu funcionamento, em vista de uma posição de poder dentro dele, de legitimar, de ter autoridade e de conduzir os discursos. O pedido de cada campo por mais autonomia, diz Bourdieu, é acompanhado de uma movimentação por maior reflexividade, de uma reflexão sobre si, de seus próprios princípios e pressupostos $^{16}$. A criação de problemas sobre determinado campo, artístico ou científico, por exemplo, está ligada à capacidade de operar sobre a tradição e a herança de cada campo, como uma condição necessária de acesso ao universo dos problemas considerados importantes e interessantes. Cada nova posição proposta no campo artístico, por exemplo, deverá ter em conta toda a História da Arte. Além de trazer a autonomia, as particularidades e os jogos de poder de cada campo, é exigido que os agentes nesse campo tenham conhecimento da lógica do jogo. Bourdieu diz que Marcel Duchamp é o "pintor ardiloso por excelência", que está no campo artístico assim como "um peixe na água", pois conhece "o jogo na ponta da língua”, o inverso do paradigma do pintor ingênuo. Assim, da mesma maneira, para os artistas a apreciação das obras de arte por parte do público depende cada vez mais do conhecimento dos jogos e de suas

${ }^{15}$ Arlindo Machado, A pesquisa em arte em três atos, 2016, p. 45. 
operações sobre a arte anterior, apreendida "pela comparação e pela referência histórica" 17.

A definição de pesquisa que interessa para esta tese, e que compõe a ideia de obra de pesquisa aqui disposta, é uma definição de pesquisa que está associada ao próprio campo, entendendo todas as definições de pesquisa artística ou pesquisa em arte, ou seja, é uma definição de pesquisa que nasce da multiplicidade de definições, métodos e discussões que foram colocados por vários artistas, estudiosos e pesquisadores da Arte. O importante é a palavrachave pesquisa, usada com rigor ou poesia, para dar conta de uma série de processos de criação artística - apropriando-se, também, de dispositivos e métodos que vêm da pesquisa acadêmica e científica ou que estão próximos das reflexões oriundas da Filosofia, da Sociologia, da História e de outros campos do conhecimento -, que adentra o projeto poético dos artistas.

Além de trazer um breve panorama sobre o surgimento dos programas próprios de pesquisa do artista em alguns países, em relação ao pioneirismo brasileiro, o Capítulo 3 coloca sobre um mesmo plano, para um entendimento renovado da pesquisa artística, as discussões e os significados propostos por vários autores como Sandra Rey, Christopher Frayling, Henk Borgdorff, James Elkins, Arlindo Machado, Kathrin Busch, Victor Burgin, Lucia Leão, entre outros, entrelaçando os debates recentes na Europa com o desenvolvimento da pesquisa em arte no Brasil, país que vem tentando dar explicações para essas questões de forma mais sistemática desde os anos 1980. Também ajudaram nesse entendimento sobre os significados da pesquisa artística as respostas de um grupo relevante de artistas-pesquisadores brasileiros - Bia Medeiros, Gilbertto Prado, Hélio Fervenza, José Spaniol, Livia Flores, Mabe Bethônico, Milton Machado, Milton Sogabe, Raquel Stolf e Sylvia Furegatti -, chamados a colaborar nesta tese a partir de uma lista de afirmações, presentes no Anexo 1 desta tese, sobre a relação entre produção artística e produção de texto, e sobre a relação entre a universidade com outros circuitos artísticos.

${ }_{17}$ Pierre Bourdieu, As regras da arte, 1992, pp. 278-280. 


\section{Obra de arte}

Vão ser utilizadas as expressões obra de arte e arte de agora com os significados da arte que está sendo pensada agora, que se origina das preocupações e dos interesses dos artistas, que vêm das questões mais urgentes da sociedade, e que também estão em relação sincrônica com determinadas linhas da arte do passado, tornadas novas porque se atualizam através da leitura feita no presente. Desse modo, esta é uma reflexão que vai se dar sobre a arte contemporânea, especialmente a produção artística das duas primeiras décadas do século 21, produzida por artistas que já não estão muito atraídos pelas generalizações estilísticas de ismos, de nomenclaturas - ou mesmo de viradas -, e tendências de periodização dominante da história. Eles estão interessados, por outro lado, nas relações entre o passado e o presente que acontecem de forma sincrônica, num plano onde várias linhas podem conectar múltiplos movimentos, artistas e obras de arte, tendências, manifestações, objetos, experiências, sensações, imagens. A expressão arte de agora é uma maneira de ressaltar a urgência do presente, uma preocupação vista em muitas produções artísticas contemporâneas, usada para o que está sendo pensado neste exato momento, ainda que o momento seja pensado de modo expandido e sincrônico. O que importa são as redes que se formam através de leituras específicas sobre determinadas linhas poéticas que estão sendo pensadas e produzidas.

Em vista da pluralidade e da multiplicidade dos projetos poéticos de agora, o que se pretende fazer aqui é uma história sincrônica da Arte, amparada pelos pensamentos de Julio Plaza ${ }^{18}$ e dos poetas concretos ${ }^{19}$, sobretudo Haroldo de Campos, no modo como pensam os projetos poéticos dos artistas em relação à história, fundamentados, por sua vez, pelo modo como Walter Benjamin ${ }^{20}$

\footnotetext{
18 Julio Plaza, Tradução intersemiótica, 2003.

19 Augusto de Campos, Décio Pignatari e Haroldo de Campos, Teoria da poesia concreta, 2006; Haroldo de Campos, Metalinguagem e outras metas: ensaios de teoria e crítica literária, 1992; Haroldo de Campos, A arte no horizonte do provável, 2010.

20 "Pensar não inclui apenas o movimento dos pensamentos, mas também sua imobilização. Quando o pensamento para, bruscamente, numa constelação saturada de tensões, ele lhe comunica um choque, através do qual ela se cristaliza numa mônada." Walter Benjamin, Sobre o conceito de história, 2017, posição 3552 (e-book). Ver também: Willi Bolle, Um painel com milhares de lâmpadas, 2007.
} 
considera a história através das ideias de mônada, montagem e constelação, e como Roman Jakobson ${ }^{21}$ desenvolve a ideia de função poética e trabalha sobre a ideia saussuriana de sincronia. Julio Plaza também vê a criação que é realizada a partir da história de duas formas: a primeira diacrônica, que se relaciona com o historicismo; e a segunda, a mais adequada à construção do projeto poético, pois está mais próxima da abertura, da incompletude e da conversa. "A história inacabada (assim como as obras de arte) é uma espécie de obra em perspectiva, aquela que avança, através de sua leitura, para o futuro ${ }^{22}$ ". Plaza segue com Haroldo de Campos e Walter Benjamin, dizendo que a história pode ser associada com uma constelação, onde o presente ilumina o passado como se fosse "uma rede eletrônica em contraposição à montagem linear da historiografia", para que a história seja capturada como reinvenção, "face um projeto do presente", como um "projeto constelativo" e "transformativo", onde a recuperação do passado se dá de forma crítica, como "um projeto não somente poético, mas também político"23.

Esta tese também teve auxílio dos filósofos Gilles Deleuze e Félix Guattari, pois aproveitou-se dos significados de certos conceitos criados por eles como linhas de fuga, pensamento como heterogênese, multiplicidades, conceitos que ampliam o entendimento sobre como se percebe e faz história, em direção a um pensamento rizomático, diagramático ou cartográfico. Na filosofia de Deleuze e Guattari, que tem uma visualidade e uma espacialidade muito peculiares, as linhas são linhas de fuga, linhas do mapa, linhas do diagrama. A imagem do rizoma, segundo eles, não é a mesma imagem da estrutura, "que se define por um conjunto de pontos e posições, por correlações binárias entre estes pontos e relações biunívocas entre estas posições”. Já “o rizoma é feito somente de linhas", guardando relação com o mapa, "que deve ser produzido, construído, sempre desmontável, conectável, reversível, modificável, com múltiplas entradas e saídas, com suas linhas de fuga"24. As linhas fogem a qualquer associação ou conexão, porque são da ordem das multiplicidades e da

\footnotetext{
${ }^{21}$ Roman Jakobson, Lingüística e comunicação, 2005.

22 Julio Plaza, Tradução intersemiótica, 2003, p. 2.

23 Julio Plaza, Tradução intersemiótica, 2003, pp. 4-8.

24 Gilles Deleuze e Félix Guattari, Mil platôs, v. 1, pp. 32-33.
} 
transformação. Por uma História da Arte que tenta se afastar do horizonte das dicotomias simplistas como formalismo e conceitualismo, artisticidade e crítica institucional, autonomia e pós-autonomia, querendo que essas ideias não sejam oposições mas coexistam e sejam lidas em determinado projeto poético ou outro. O que resta é uma multiplicidade de ideias, conceitos e teorias de artistas e pesquisadores, revistos sob o funcionamento da arte que é produzida. Desse modo, busca-se um estudo que não está comprometido com as nomenclaturas, as categorizações, as viradas e as expressões temporais totalizantes e de perspectiva única, mas que se quer próximo do modo complexo como os artistas engendram as suas poéticas através de pesquisas, teorias e conversas.

Todos esses autores vão ser encontrados também fundamentando o pensamento de JMB e RB, com maior intensidade em um ou no outro. Ainda em comum, alguns conceitos e teorias de artistas vão ajudar a fundamentar esta tese, fundamentação que se encontra nos próprios textos de JMB e RB, e também em artistas próximos a eles, como Lygia Clark ${ }^{25}$ e Hélio Oiticica ${ }^{26}$, Allan Kaprow $^{27}$ e Robert Smithson ${ }^{28}$, a partir de ideias como linha orgânica, objeto relacional, experimental, ambiental, an-artista ${ }^{29}$, atividades, monte de linguagem, non-site. Esta pesquisa preocupa-se, em certa medida, com muitos estudos recentes de teóricos e historiadores da arte, de filósofos e até de pesquisadores de outros campos do conhecimento. Porém, coloca-se em evidência o pensamento que vem dos próprios artistas, das teorias de artista e do funcionamento das obras de arte. Muitos artistas através da história mostraram um interesse intelectual especial sobre a reflexão, a interpretação, a discursividade e o diálogo, ou mesmo a literatura, aproximando-se da escrita, apresentando suas ideias na forma de textos e propondo conceitos para lidar com a arte e o mundo. Nesse sentido, o processo de pesquisa que resulta em escritos e teorias dos artistas, conversas e projetos discursivos, como é o caso de JMB e RB, faz enredar histórias, situações e camadas textuais como obras de

25 Lygia Clark, Livro-obra, 1983.

${ }^{26}$ Hélio Oiticica, Conglomerado Newyorkaises, 2013.

27 Allan Kaprow, Essays on the Blurring of Art and Life, 1993.

${ }^{28}$ Robert Smithson, The Collected Writings, 1996.

29 Tradução indicada por RB para un-artist. Ver: Allan Kaprow, A educação do an-artista II, 2004. 
arte, sendo que elas são especialmente efêmeras, espalhadas, plurais e de difícil localização, às vezes ocorrendo dentro da obra de outros artistas. Por isso, um recorte do projeto poético desses artistas será lido, descrito e colocado em comparação com alguns fenômenos e ideias artísticas recentes, bem como com uma rica produção de teses e dissertações brasileiras em Artes Visuais, sendo que muitas delas são de artistas.

A ideia de obra de arte nesta tese, além de ser expressão importante para JMB e RB, comporá a expressão obra de pesquisa, ideia que se associa a diversos conceitos, palavras-chave e proposições artísticas, criadas ou utilizadas por diversos artistas e autores, e que são importantes para a arte que é feita agora. Entre essas ideias, pode-se citar: a pesquisa artística ${ }^{30}$ ou pesquisa em arte ${ }^{31}$; a virada educacional e os projetos pedagógicos feitos por artistas ou curadores32; a discursividade, o relacional, o dialógico e o social33; o sitespecificity considerado como uma operação discursiva que resulta em sites discursivos e uma metodologia de pesquisa artística34; os escritos e as teorias de artista35; o artista ou autor como produtor ${ }^{6}$ ou como alguém que provê serviços37; o agrupamento de artistas em coletivos $^{38}$ e a criação de circuitos independentes, tais como revistas, espaços, grupos de estudos e pesquisa, escolas, ou a circulação por variados circuitos e instituições, onde artistas

${ }^{30}$ Henk Borgdorff, The Conflict of the Faculties, 2012; Henk Slager, The Pleasure of Research, 2015; Hito Steyerl, Estética da Resistência?, 2016; Jorge Menna Barreto, Exercícios de leitoria, 2012; Sidsel Nelund, Acts of Research, 2014.

${ }^{31}$ Silvio Zamboni, A pesquisa em arte, 1998; Sandra Rey, Da prática à teoria, 1996.

${ }^{2}$ Paul O’Neill e Mick Wilson (ed.), Curating and the Educational Turn, 2010; Claire Bishop, Artificial Hells, 2012; Mônica Hoff Gonçalves, A virada educacional nas práticas artísticas e curatoriais contemporâneas e o contexto de arte brasileiro, 2014.

33 Nicolas Bourriaud, Estética relacional, 2009; Jacques Rancière, O espectador emancipado, 2012; Grant Kester, Conversation Pieces, 2004; Claire Bishop, Artificial Hells, 2012; Marisa Flórido Cesar, Nós, o outro, o distante, 2014.

34 Rosalind Krauss, A escultura no campo ampliado, 2008; Miwon Kwon, One Place After Another, 2002; Jorge Menna Barreto, Lugares moles, 2007.

35 Ricardo Basbaum, Além da pureza visual, 2007; Ricardo Basbaum, Você gostaria de participar de uma experiência artística $(+N B P)$.

${ }_{36}^{6}$ Walter Benjamin, O autor como produtor, 2012; Okwui Enwezor, The Artist as Producer in Times of Crisis, 2005.

37 Andrea Fraser, Como prover um serviço artístico, 2013.

${ }^{38}$ Fernanda Carvalho de Albuquerque, Troca, soma de esforços, atitude crítica e proposição, 2006; André Luiz Mesquita, Insurgências poéticas, 2008; Cláudia Paim, Coletivos e iniciativas coletivas, 2009. 
propõem aulas, oficinas, palestras, publicações, exposições etc.39; a importância da inter, multi, extra ou transdisciplinaridade da arte que se move apropriandose de outros campos do conhecimento ou associando-se a eles, interessada em assuntos, histórias e pesquisas específicas40; a utilização de vários meios tecnológicos, de produção e de distribuição, como um desinteresse por afirmar um único meio ${ }^{41}$; as ideias de rede e de sistema ${ }^{42}$, que fazem a obra ser considerada complexa e incompleta ao mesmo tempo, espalhada no tempo e por diversos meios, lugares, ações e conversas, trazendo para dentro de si e disparando diversos tipos de participações e colaborações; e, enfim, as estratégias artísticas que estão no limite com as estratégias acadêmicas, científicas, educacionais e teóricas, que permitem que o conhecimento e o pensamento estejam instalados na obra de arte.

Também importante tanto para a arte de agora quanto para esta tese é a ideia de dispositivo, que parte de vários autores e é utilizada de muitos jeitos pelos artistas, uma ideia que fala sobre meios, objetos, estruturas, estratégias, ferramentas, visualidades que o artista engendra para fazer funcionar a obra de arte. O dispositivo é um aparato ou um aparelho, uma ferramenta ou um instrumento, uma estratégia e um processo, um meio e um veículo, uma estrutura ou uma construção, uma máquina e um utensílio, pode falar de métodos e também de configurações. Na ideia de dispositivo também há um componente que se relaciona com as regras, os protocolos e o poder. $\mathrm{O}$ conceito de dispositivo é conhecido pelo uso que dele fez Michel Foucault, embora nunca o tenha definido em livro, e das leituras de Deleuze e Giorgio Agamben sobre os significados desse uso. Para Agamben, o dispositivo é "qualquer coisa que tenha de algum modo a capacidade de capturar, orientar, determinar, interceptar, modelar, controlar e assegurar os gestos, as condutas, as opiniões e os discursos

39 Ricardo Basbaum, Amo os artistas etc., 2013; Vanessa Schultz, Lugar publicação, 2008; Bettina Rupp, Residências em arte contemporânea, 2017.

40 Julio Plaza, Arte/ciência, 2003; Hal Foster, $O$ retorno do real, 2014; Arthur C. Danto, $O$ descredenciamento filosófico da arte, 2014; Brian Holmes, Investigações extradisciplinares, 2008; Néstor García Canclini, A sociedade sem relato, 2012; Reinaldo Laddaga, Estética de laboratório, 2013.

${ }_{41}$ Julio Plaza, Poéticas visuais, 1977; Rosalind Krauss, A Voyage on the North Sea: Art in the Age of the Post-Medium Condition, 2000; Nicolas Bourriaud, Pós-produção, 2009; Seth Price, Dispersion, 2002.

${ }^{42}$ Jack Burnham, System Esthetics, 1968; Alfred Gell, Arte e agência, 2018. 
dos seres viventes"43. Prisões, escolas, fábricas, disciplinas e também caneta, literatura, filosofia, navegação, computadores, linguagem: uma multiplicidade de dispositivos. Para Deleuze, o dispositivo é um "conjunto multilinear", um conjunto composto de linhas diversas, que se movimentam, linhas de força que vão de um lugar a outro, passando "por todos os lugares". O dispositivo é ao mesmo tempo "máquinas de fazer ver e de fazer falar", ou seja, trabalha através da visibilidade e da enunciação. $O$ dispositivo também pode ser compreendido como diagrama e como máquina, como um produto que gera esquematicidade de pensamento, para tratar ou negar a ideia de representação. Serve para significar tanto os dispositivos materiais e técnicos quantos os dispositivos linguísticos e discursivos, onde vários dispositivos de diversos tipos estabelecem conexão entre si, sendo essa rede considerada também um dispositivo44. Nesta tese, os dispositivos da pesquisa são tanto os expositores e os objetos que estão dispostos, montados e exibidos em um ambiente de pesquisa, quanto os processos e os métodos da pesquisa. Na arte de agora, intensifica-se o interesse de artistas, curadores e museus por dispositivos, que são os formatos, as ferramentas, os processos e as experiências compartilhados com pesquisadores, teóricos e também professores. Várias obras de arte hoje se utilizam das linhas poéticas da pesquisa como meio, linguagem, material, em projetos que se apropriam tanto dos formatos e das ferramentas do pesquisador, quanto dos processos e das experiências da pesquisa.

Da passagem para o século 21 intensificou-se também uma preocupação social e engajada, bem como o interesse dos artistas pelos processos participativos e colaborativos, geralmente com um enfoque ou engajamento social e político, em muitos casos orientado ao conhecimento, em projetos artísticos que se dão a partir da pesquisa e do ensino. A obra, distante de suas qualidades objetuais e estáticas, torna-se um projeto em andamento, em que o papel do artista é mais o de um colaborador e propositor de situações e atividades e, deste modo, as pessoas que participam ou colaboram na obra de arte se tornam cocriadoras. Na arte da participação, da colaboração, do diálogo,

43 Giorgio Agamben, O que é um dispositivo?, 2009, pp. 40-41.

44 Gilles Deleuze, O que é um dispositivo?, 2016. 
do contexto ou socialmente engajada, em vez de objetos ou qualquer outra técnica e linguagem específicas, o público também pode ser considerado material e dispositivo artístico.

O artista não é mais o criador de obras de arte apenas para serem exibidas, pois eles avançam para uma problematização mais ampla sobre o conhecimento. A Arte quer trazer, investigar e propor teorias a respeito de si mesma e do mundo, em um movimento de cruzamento e associação com outros campos do conhecimento, e isso é muito novo, pela quantidade de artistas que pesquisam, teorizam e se envolvem com atividades discursivas, e também pela multiplicidade de disciplinas que a Arte traz para colaborar, antes mais evidentes na relação com a Filosofia, a Matemática, a Engenharia e a Comunicação. O objetivo final não é mais o da criação e exibição de obras, não mais do modo como se criava e exibia anteriormente. Um dos problemas da arte do século 21 já não é mais saber se "isto" é ou não arte, mas antes o problema da exibição da obra de arte que se engaja na pesquisa e na teoria, tratadas como matéria fundamental de sua produção. 

CAPÍTULO 1

PESQUISA DO ARTISTA

NA UNIVERSIDADE BRASILEIRA 



\section{Escola de Belas Artes}

No decreto de fundação da Universidade de São Paulo (USP), de 1934, estava prevista uma "Escola de Belas Artes" como um de seus institutos oficiais. Mas o investimento sobre cursos superiores de Artes Visuais (História e Teoria da Arte, Produção Artística, Arte-Educação etc.), por parte da USP, demoraria um pouco mais para acontecer45. Uma Escola de Comunicações Culturais (ECC), ofertando os cursos de Rádio e Televisão, Arte Dramática, Cinema, Jornalismo, Documentação, Relações Públicas e Biblioteconomia, foi criada em 196646. Entre o final da década de 1960 e o começo da década de 1970, período conturbado marcado pelos movimentos estudantis, Ato Institucional $\mathrm{n}^{\mathrm{0}} 5$ (AI-5) e Reforma Universitária47, e não sem a insistência e a luta de alguns professores que já vinham elaborando um projeto de criação de um Instituto de Artes, foram criados os departamentos de Artes Plásticas e Música, por isso a mudança de nome para Escola de Comunicações e Artes (ECA). Antes disso, o ensino e a pesquisa relacionados às Artes na USP se davam por interesse de alguns professores e em aulas específicas dentro de cursos, principalmente História da Arte, na Faculdade de Arquitetura e Urbanismo (FAUUSP) ou na extinta Faculdade de Filosofia, Ciências e Letras ${ }^{48}$. O desejo por um Instituto de Artes da USP reaparecerá em vários momentos sem êxito: antes do surgimento da ECA como um projeto de criação, que em vários momentos veio à tona, e depois como um projeto de desmembramento da área de Comunicação, plano que vez ou outra ressurge.

O ensino superior no Brasil só começou depois da chegada da família real portuguesa em 1808. São exemplos iniciais o deslocamento da Academia de Marinha para o Rio de Janeiro e a criação da Escola de Cirurgia da Bahia. Entre

45 Ana Mae Barbosa, Educação artística, 1994, p. 491.

46 Virgílio Noya Pinto, Escola de Comunicações e Artes, 1994, pp. 503-504.

47 Sobre a reforma universitária, efetuada pelo regime militar a partir de 1968, que substitui a organização das faculdades e escolas em departamentos em vez de cátedras, entre outras mudanças, ver: Rodrigo Patto Sá Motta, As universidades e o Regime Militar: Cultura política brasileira e modernização autoritária, 2014; Luiz Antonio Cunha, A universidade reformada: O golpe de 1964 e a modernização do ensino superior, 1988.

48 Walter Zanini, Elementos sobre a pesquisa em Artes Plásticas no Brasil e ANPAP (1987-1989), 2008, p. 33. 
as primeiras escolas lançadas por dom João VI está a Escola Real de Ciências, Artes e Ofícios49, que em 1816 inaugura o ensino superior de Artes no Brasil, como desdobramento da vinda dos artistas da Missão Artística Francesa, em nomes como Jean-Baptiste Debret, Nicolas Antoine Taunay e Auguste Henri Victor Grandjean de Montigny. Durante o Império, a escola foi chamada de Academia Imperial das Belas Artes; após a Proclamação da República, de Escola Nacional de Belas Artes e, a partir de 1931, de Escola de Belas Artes, com a incorporação pela Universidade do Brasil, hoje Universidade Federal do Rio de Janeiro (EBA- UFRJ).

Entre os exemplos pioneiros de escolas e institutos superiores de artes no Brasil, anteriores ao estabelecimento do departamento de Artes Visuais na USP estão50: a Escola de Belas Artes da Bahia, fundada em 1877 e desde 1948 parte da Universidade da Bahia, hoje federal (UFBA); o Instituto de Belas Artes de Porto Alegre, criado em 1908, com seu curso de Artes Plásticas reconhecido em 1941 e desde 1962 Instituto de Artes da Universidade Federal do Rio Grande do Sul (IA-UFRGS); a Escola de Belas Artes de Pernambuco, aberta em 1932, e parte da Universidade de Recife a partir de 1946, foi integrada em 1975 ao recém-criado Centro de Artes e Comunicação da Universidade Federal de Pernambuco (UFPE); a Escola Guignard, absorvida como unidade desde a criação da Universidade Estadual de Minas Gerais (UEMG) em 1989, foi inaugurada como Escola de Belas Artes, dirigida pelo artista Alberto da Veiga Guignard de 1943, ano da inauguração, até 1962, ano de sua morte; a Escola de Belas Artes de Pelotas, inaugurada em 1949 e integrada à Universidade Federal de Pelotas (UFPel) em 1973, como Instituto de Artes, e desde 2010 Centro de Artes; a Escola de Belas Artes do Espírito Santo, criada em 1951, encampada pela Universidade do Espírito Santo (UFES) e transformada em Centro de Artes em 1971; a Escola de Belas Artes da Universidade Federal de Minas Gerais (UFMG), que existe desde 1957 como curso de Arte, primeiro dentro da Escola de Arquitetura, depois tornada unidade acadêmica em 1968; a Faculdade de

49 Para um panorama retrospectivo da Escola até os anos 1990, passando pela mudanças efetuadas nos anos 1930 pela gestão de Lúcio Costa, ver: Carlos Zilio, Formação do artista plástico no Brasil: o caso da Escola de Belas Artes, 1994, pp. 25-32. 
Belas Artes da Universidade Federal de Santa Maria (UFSM) teve seu curso de Desenho e Plástica iniciado em 1964; também deve ser citado o Instituto de Artes (IdA) da Universidade de Brasília (UnB), criado em 1988, retomando a autonomia do extinto Instituto Central de Artes (ICA), que começou a funcionar com a inauguração da UnB em 1962 - depois do golpe militar de 1964, o instituto bem como a universidade começaram a sofrer com a repressão e violações dos direitos humanos, e em 1971 houve o desmembramento do ICA em vários departamentos.

\section{Criação do doutorado de artista}

Se o ensino superior em Artes Visuais na USP demorou para ser estabelecido, tendo em vista os exemplos brasileiros citados anteriormente, já em 1974, quatro anos após a abertura do departamento de Artes Plásticas, a ECA vai ser precursora na implantação de uma programa de pós-graduação com uma área específica para a criação do artista chamada "Poéticas Visuais", e que estará em convívio com outras áreas teóricas do programa, como Teoria, Ensino e Aprendizagem da Arte -, primeiramente no curso de mestrado e depois em uma das primeiras experiências deste tipo de doutorado no mundo, desenvolvida por Regina Silveira, rumo ao estabelecimento da pesquisa artística na universidade. Segundo Walter Zanini, outro grande responsável por esse pioneirismo, o departamento de Artes Plásticas da ECA tornou-se referência para os futuros mestrados e doutorados que estavam surgindo. ${ }^{11} \mathrm{O}$ fato também é citado por Gilbertto Prado, em seu relato que evidencia o papel da ECA "na disseminação dessa experiência através de seus participantes, alunos e professores de outras universidades" ${ }^{2}$ que passaram por lá e, assim, puderam ajudar a desenvolver programas e cursos em outros lugares do Brasil. Prado também fala como foram importantes as presenças de Walter Zanini, Regina Silveira e Julio Plaza53 para o clima de efervescência, aumentada pela passagem

\footnotetext{
${ }^{51}$ Walter Zanini, Arte e história da arte, 1994, p. 488.

$5^{2}$ Gilbertto Prado, Breve relato da pós-graduação em Artes Visuais da ECA-USP, 2009, p. 92.

53 Julio Plaza, Regina Silveira e Walter Zanini também mantiveram, com Donato Ferrari, a escola independente chamada Centro de Estudo Áster, entre 1978 e 1981.
} 
de vários artistas de fora do país convidados a dar aulas na escola, que se constituiu como "um dos grandes centros de produção e difusão de conhecimento, no Brasil e internacionalmente"54. Marco Giannotti diz que a criação de uma linha de pesquisa específica para o artista foi uma grande conquista do departamento de Artes Plásticas da ECA, “devido ao empenho da Regina Silveira, e acaba de uma vez por todas com esta mística de que um artista não pode realizar uma atividade intelectual, reflexiva, concomitante a sua produção" 55 .

Em conversa concedida para esta pesquisa, Regina Silveira ${ }^{56}$ diz que a ideia de defender mestrado e doutorado com obra de arte já estava sendo gestada no momento da criação do departamento de Artes Plásticas no começo dos anos 1970. Segundo a artista, além de Walter Zanini, grandes promotores da pós-graduação na ECA e, consequentemente da pesquisa em Artes Visuais, foram os professores Fredric Michael Litto e Eduardo Penuela Cañizal57, pois a criação da pós-graduação em Arte seguiu a movimentação de criação dos outros programas de pós-graduação dessa escola. Outros departamentos, ao criarem seus programas, também estavam incluindo esse tipo de pesquisa de produção ou baseada na prática. Mestrados em Rádio e TV, Cinema e Teatro e Artes Plásticas surgiram entre 1972 e 1974, sendo que os doutorados surgiram em 1980. Os departamentos da ECA tiveram que se enquadrar no padrão da pósgraduação brasileira, para que seus professores obtivessem títulos de mestre e doutor. A partir daí, um ambiente institucional começou a ser criado, um ambiente propício para que os artistas começassem a fazer seus mestrados e doutorados e pudessem obter bolsas e auxílios financeiros. Em um primeiro momento, houve a necessidade de os artistas procurarem orientadores de outras

54 Gilbertto Prado, Breve relato da pós-graduação em Artes Visuais da ECA-USP, 2009, p. 93.

55 Depoimento encontrado em: Juliana Monachesi e Tatiana Ferraz, Arte e universidade, 2003.

${ }_{56}^{6}$ Conversa com Regina Silveira realizada em São Paulo, na manhã do dia 26 de junho de 2018, para esta tese. O relato é baseado em anotações, já que a artista pediu para que a conversa não fosse gravada. A maior parte das próximas citações vem dessa conversa.

57 Segundo Margarida Kunsch, uma das frentes de atuação da ECA sobre a pós-graduação consistiu na batalha levada a cabo por professores como Fredric Litto, Eduardo Peñuela Cañizal e José Marques de Melo pela inserção da área de Comunicação como um campo do conhecimento autônomo dentro da grande área de Ciências Sociais Aplicadas. A autora também destaca a atuação do professor Walter Zanini na área de artes visuais. Ver: Margarida Maria Krohling Kunsch, Escola de Comunicações e Artes (ECA-USP), 2015, p. 37. 
áreas, porque não haviam artistas doutores. O historiador da arte Wolfgang Pfeiffer foi quem orientou Regina Silveira, que por sua vez, já como doutora, tornou-se orientadora de uma nova geração de artistas.

Em 1980, a artista defendeu o mestrado iniciado em 1976, uma pesquisa que contou com o apoio da CAPES. A defesa foi composta pela dissertação e por uma exposição apresentadas no Museu de Arte Contemporânea (MACIbirapuera), que naquela época ocupava parte do $3^{\circ}$ piso do Pavilhão da Bienal. Com o título Anamorfas, o trabalho consistiu "em uma produção artística e um 'texto descritivo"' com referências à produção anterior da artista e à história da arte, "através de aspectos conceituais relacionados com a obra, a partir de uma bibliografia" ${ }^{8}$. A obra de pesquisa desenvolveu-se fundamentada, por exemplo, nas ideias e no "tratamento teórico-prático" de Leonardo da Vinci sobre a "perspectiva artificial", os "múltiplos pontos de vista" de Paolo Ucello, as perspectivas curvilíneas das miniaturas de Jean Fouquet, as "opticeries" de Marcel Duchamp, entre outros. Segundo a artista, a obra de arte Anamorfas não é uma ilustração da discussão sobre a perspectiva, mas a conclusão de um raciocínio visual gerado também pela leitura destes textos e obras59. A artista diz que teve a ajuda de Fredric Litto - na época professor de Metodologia Científica - para formatar o seu projeto de pesquisa, sendo ele também quem a incentivou a pedir auxílio financeiro para essa pesquisa. A defesa do álbum de gravuras Anamorfas foi apresentado como que cientificamente, diz ela, que teve que começar a desbravar a questão da metodologia científica e trabalhar com os protocolos vindos da Ciência.

O estudo sobre a perspectiva, iniciado no mestrado, será continuado no doutorado com a pesquisa sobre as "sombras projetadas", uma pesquisa artística que atravessará toda a trajetória da artista. A publicação depositada de Simulacros, que se encontra na Biblioteca da ECA, apresenta-se como um "memorial descritivo da tese de doutorado", fundamentado em vários tratados sobre perspectiva, sobretudo o Tratado de pintura, de Leonardo da Vinci, e inspirado em fontes artísticas como Marcel Duchamp, M. C. Escher, Jan

$5^{8}$ Depoimento de Regina Silveira a Milton Sogabe realizado em 30 abril de 2012. Ver: Milton Sogabe, Arte e pesquisa na academia, 2014, p. 27.

59 Regina Silveira, Anamorfas, 1980, pp. 9-10. 
Dibbets, entre outros artistas que são comentados neste texto. A pesquisa, que foi orientada por Wolfgang Pfeiffer e teve o apoio do Conselho Nacional de Desenvolvimento Científico e Tecnológico (CNPq) e da Fapesp, "compreende quatro grupos de trabalhos, constituídos por séries gráficas e instalações ambientais"6o. Simulacros (1984) liga-se a Anamorfas (1980), mas sobretudo a outras obras que se desdobraram a partir de então, e são apresentadas no memorial descritivo da tese também como simulacros: as séries Enigmas (1981), Dilatáveis (1982), Símiles (1983) e Topo-Sombras (1983), as instalações Projectio I e II (1984), e In Absentia M.D. (1983), que foi exibida na $17^{\mathrm{a}}$ Bienal de São Paulo, edição que teve a curadoria de Walter Zanini. Os textos de Anamorfas e Simulacros são chamados de "texto descritivo" e "memorial descritivo", o que faz essas propostas de mestrado e doutorado serem consideradas pioneiras, pois são focadas na pesquisa de produção artística, um tipo de pesquisa do artista que foi discutida na Europa nos últimos anos, de um doutorado voltado à produção ou à prática de estúdio.

Antes de Regina Silveira, Renina Katz na FAUUSP havia defendido com produção artística e memorial descritivo, tanto em seu mestrado de 1979, intitulado Matrizes modificadoras do campo plástico, quanto em seu doutorado de 1982, intitulado Lugares: 13 litografias originais, algo muito próximo do que estava sendo desenvolvido na ECA como aquilo que deveria ser a pesquisa do artista na universidade. $\mathrm{O}$ artista Claudio Tozzi, sob orientação de Aracy Amaral, também defendeu com obra de arte a sua dissertação de mestrado chamada Obra de arte e sua multiplicação: Estudo do processo de reprodução por serigrafia, em 1980 . Regina Silveira ${ }^{61}$ diz que a FAUUSP saiu na frente, mas foi algo que não se estabeleceu. Esse tipo de pesquisa, realizado pelo artista, acabou tendo um desenvolvimento mais duradouro e consistente no programa de Artes Visuais da ECA, e depois em várias universidades públicas espalhadas pelo país, em vista da ligação com a graduação específica em Arte, pelo número de artistas envolvidos, e também porque um modelo do que deveria ser a pesquisa artística foi desenvolvido dentro desses programas.

\footnotetext{
${ }^{60}$ Regina Silveira, Simulacros, 1984, p. 4.

${ }^{61}$ Conversa com Regina Silveira realizada em São Paulo, na manhã do dia 26 de junho de 2018, para esta tese.
} 
Uma das necessidades naquele primeiro momento, princípio do que deveria ser a pesquisa do artista na universidade, era equiparar a pesquisa artística com a pesquisa acadêmica. Segundo Regina Silveira, havia um preconceito muito grande do restante das Ciências em relação a esse tipo de pesquisa que, aqui no Brasil, veio a se chamar pesquisa em arte. Essa conversa estava sendo travada não só no departamento de Artes Visuais, mas essa era uma tentativa de defesa da pesquisa do artista que estava sendo feita também na Música e no Teatro. No Cinema e em outras áreas de Comunicação da ECA, segundo a artista, essa validação ocorreu de forma mais descomplicada. Por não haver parâmetros, modelos e definições do que deveria ser a pesquisa artística na universidade - tudo o que se estava pensando e fazendo ali era novo -, Regina Silveira diz que aos poucos os artistas e seus orientadores, geralmente historiadores ou teóricos da arte, tiveram que construir e imaginar algumas regras, estipular alguns padrões, e isso foi se desenvolvendo conforme mais artistas se engajavam na universidade. Alguns consensos já começavam a ser feitos, como o de que que somente o título de mestre ou doutor não garantiria ao artista um lugar na universidade, porque este teria que provar também a sua qualidade como artista. Também era defendido que arte na universidade deveria ser ensinada por aqueles que já tivessem uma trajetória consistente. Os modelos e os parâmetros tiveram que ser criados ali, sem conexão com outras universidades, embora alguma influência fosse sentida do Master of Fine Arts americano, já existente na época, mais prático ou de produção. Em geral, fora do Brasil, mestrados não possuem o reconhecimento ou o nível de complexidade que tem aqui. A pós-graduação brasileira acabou desenvolvendo um mestrado com desenvolvimento e exigência de defesa comparados quase que com os do doutorado62. De forma geral, Regina Silveira diz que não havia tanto conhecimento ou conexão com outras movimentações pioneiras, entre os anos 1970 e 1980, de criação de doutorados próprios para os artistas que começava a acontecer, hoje se sabe, também em países como Reino Unido, Austrália e Japão.

${ }^{62}$ Sobre o prestígio e o rigor atribuídos ao mestrado no Brasil, ver: Cássio Miranda dos Santos. Tradições e contradições da pós-graduação no Brasil, 2003. 
O que está em jogo aqui nesta tese, pelo menos em um primeiro momento, não é só a importância da presença do artista na universidade, mas a criação e o pioneirismo de programas que tenham doutorados voltados aos artistas, e a validação da produção artística como resultado da tese ou parte de sua defesa. Regina Silveira diz que o modelo desse novo tipo de pós-graduação que até hoje é nomeado como "Poéticas Visuais" vinham da própria cena da arte: uma cena intermídia e interdisciplinar, uma cena que em São Paulo girava em torno de Walter Zanini63, da artista e de Julio Plaza64. Zanini, além de chefe do departamento de Artes Plásticas da ECA entre 1972 e 1984, foi diretor do MAC-USP, um museu universitário, da inauguração, em 1963, a 1978, onde organizou o programa de exposições Jovem Arte Contemporânea (JAC), além de exposições emblemáticas em colaboração com Julio Plaza como Prospectiva 74 e Poéticas visuais 77, sendo que o nome da linha de pesquisa "Poéticas Visuais" tem conexão com esta última exposição. Regina Silveira fala que havia um "fundo conceitual" próprio daquele período, uma perspectiva de pesquisa que vinha da própria arte realizada entre as décadas de 1970 e 1980 e que orientava o que se deveria constituir a pesquisa do artista, agora na universidade. A pesquisa artística começou a ser desenvolvida dentro de um contexto "intermídia", "multimídia", "intersemiótico" e "interdisciplinar"65, com uma arte que não se prende a técnicas, suportes ou formatos predeterminados, aberta a pesquisas sobre os campos da Comunicação e sobre os novos meios, fazendo com que a relação entre produção e pesquisa ocorresse de forma muito espontânea. Não existia ainda uma ideia de pesquisa artística ou em arte tão formatada, e Marcel Duchamp e Leonardo da Vinci eram dois nomes exemplares de artistas que desenvolveram uma arte próxima da pesquisa. Também havia, como diz Regina Silveira, uma tendência de equiparar a

63 Sobre Walter Zanini e a cena artística em torno do MAC-USP, que oscilava entre os novos meios e a arte de processo, ver: Cristina Freire, Poéticas do processo, 1999, pp. 24-25; 58-59; Arlindo Machado (org.), Made in Brasil, 2007, pp. 51-82; Dária Jaremtchuk, MAC do Zanini, 2012, pp. 69-86; Walter Zanini, Isis Baldini et al., Walter Zanini e a formação de um sistema de arte contemporânea no Brasil, 2018.

64 Sobre Julio Plaza, ver memorial escrito por ele em 1994 e depoimento de Regina Silveira sobre o artista em: Vera Chaves Barcellos (org), Julio Plaza Poetica/Política, 2013. O livro conta com um documentário de $31 \mathrm{~min}$, disponível online em: Julio Plaza, o poético e o político (Vídeo), 2013, https://youtu.be/bOhsAjTBhBM. 
pesquisa do artista com modelos vindos da ciência e da tecnologia, dentro de uma tradição que havia atravessado o século 20, e que encontrará na universidade um lugar muito apropriado para ser desenvolvido.

\section{Pesquisa em Arte}

Com o termo histórico pesquisa em arte, Silvio Zamboni diferencia pesquisas empreendidas por "artistas que objetivam obter como produto final a obra de arte"66, em que o artista se "assume como pesquisador", das pesquisas desenvolvidas em outros campos das artes, como história e teoria da arte, arteeducação, restauro, curadoria etc., que já possuem há mais tempo metodologias próprias, bem como área de atuação mais clara. O termo é histórico porque delimita um lugar para a pesquisa do artista dentro da universidade brasileira, composta de reflexão e produção artística, e conta sobre um percurso de validação que vai da criação de programas de pós-graduação em Arte nas universidades, passando pelo reconhecimento oficial de toda a área de Artes como área de pesquisa acadêmica pelo $\mathrm{CNPq}^{67}$, até a organização de comunidades de pesquisadores, como é o caso da Associação Nacional de Pesquisadores em Artes Plásticas (ANPAP).

$\mathrm{Na}$ época em que Regina Silveira fez suas pesquisas de mestrado e doutorado, entre os anos 1970 e 1980, o campo muito vasto das Artes, que inclui além das Artes Visuais, o Teatro e a Música, por exemplo, não era oficialmente reconhecido como um campo de pesquisa por nenhuma agência de fomento, e os poucos projetos de pedido de recurso apresentados eram julgados por pesquisadores de outras áreas. Esse panorama de escassez começou a se transformar em vista da atuação do ex-funcionário do CNPq, Silvio Zamboni, quando ainda dentro da coordenação de Ciências Sociais, em oportunidade dada pelo então superintendente de Desenvolvimento Científico, Marcos Formiga e pelo antropólogo George Zarur, da Coordenadoria de Ciências Humanas, foi incumbido com a tarefa de formar um embrião da área artística

${ }^{66}$ Silvio Zamboni, A pesquisa em arte, 1998, p. 6.

${ }_{67} \mathrm{O}$ CNPq foi criado em 1951, com o objetivo de fomentar pesquisa científica e tecnológica no país através da concessão de recursos na forma de auxílios e bolsas. 
dentro do órgão ${ }^{68}$. Até então, segundo Zamboni, alguns poucos trabalhos de Artes, incluindo História da Arte, eram julgados, mas isso era feito de forma "clandestina", "precária”, sem os critérios específicos que a área exige, avaliados por pareceristas de Comunicação. No começo dos anos 1980, Zamboni começou a fazer contato com pesquisadores das Artes, viajando e fazendo reuniões em muitas escolas e faculdades de várias partes do país, de forma a divulgar as vias de acesso e os modos corretos de solicitação, "despertando a comunidade para a existência desse espaço institucional e para a possibilidade de conseguir auxílio financeiro para desenvolver seus projetos de pesquisa ${ }^{69}$. Silvio Zamboni diz que era necessário, naquele momento, explicar para os artistas, arte-educadores, teóricos e historiadores da arte que eles deveriam pedir, porque os diretos são os mesmos tanto para "os físicos, os químicos, os biólogos", quanto para eles70. Depois dessas viagens, e com o aumento dos pedidos para bolsas e auxílios, criou-se um Comitê Assessor, agora especializado para julgar as propostas ${ }^{71}$. A partir disso foi possível negociar com os dirigentes a necessidade da oficialização da área, inclusive para esclarecimento àqueles membros do órgão que consideravam a Arte como algo fora da Ciência e da pesquisa, com a alegação de que não haveria critérios científicos para definir os projetos a serem aprovados $^{72}$. Segundo Walter Zanini, havia "o obstáculo de prevenções e objeções de áreas científicas, sobretudo a resistência entre as 'exatas', (...) uma opinião pouco ou nada sensível à subjetividade caracterizadora do pensamento artístico"73. Após muitas reuniões e não sem divergências, a área de Artes foi aprovada pelo CNPq em 1984.

A criação de uma Associação Nacional dos Pesquisadores em Artes Plásticas ocorreu em 1986 como desdobramento desses esforços e através da figura atuante de Silvio Zamboni, que agora tinha também a tarefa de ajudar a

68 Walter Zanini, Elementos sobre a pesquisa em Artes Plásticas no Brasil e ANPAP (1987-1989), p. 35 .

69 Silvio Zamboni, Alguns fragmentos da história das Artes Plásticas no Brasil (1993-1995), 2008, p. 56.

70 Silvio Zamboni, Entrevista com Silvio Zamboni (Vídeo), 2011, https://youtu.be/jSc1IIt4wOg.

${ }^{71}$ Viviane Ferreira Caixeta, $A$ institucionalização do fomento à pesquisa em artes no CNPq, $\mathrm{p}$. 43.

72 Silvio Zamboni, Alguns fragmentos da história das Artes Plásticas no Brasil (1993-1995), p. 55.

73 Walter Zanini, Elementos sobre a pesquisa em Artes Plásticas no Brasil e ANPAP (1987-1989), p. 36 . 
estabelecer a subárea de artes visuais ${ }^{74}$ como um campo de pesquisa acadêmica, com parâmetros específicos de pesquisa em e sobre artes, organizado por seus pesquisadores com interesses diversos. Além do interesse dos artistas, formalizado em um comitê chamado "Linguagens Visuais", hoje chamado de "Poéticas Artísticas", a ANPAP é dividida, nos termos atuais, em mais outros quatro comitês: "História, Teoria e Crítica de Arte", "Educação em Artes Visuais", "Curadoria" e "Patrimônio, Conservação e Restauro". Segundo Zamboni, esses outros quatro comitês não tiveram dificuldades no processo de conceituação e caracterização, porém, o mesmo não pode ser dito em relação ao comitê designado à pesquisa dos artistas75, até hoje motivo de grandes debates e incertezas no Brasil e no mundo, não só para outros cientistas e acadêmicos, mas também para os próprios artistas e outros pesquisadores da área de Artes Visuais, sendo que alguns pontos dessa problemática serão vistos ao longo dessa tese. Por outro lado, é interessante notar que na criação da associação há o esforço em evidenciar a demarcação de um lugar de pesquisa na universidade e uma regulamentação em órgãos de auxílio financeiro para a pesquisa feita pelo artista. Sobre isso, Walter Zanini diz que: "Muitos debates a marcaram, principalmente ao tratar-se o ponto nevrálgico da formulação da pesquisa pelo artista"76. Tanto é assim que são fundadores da ANPAP os artistas Regina Silveira, Paulo Bruscky, Suzete Venturelli, Anna Barros, Anna Bella Geiger, Diana Domingues, entre outros. Entre os críticos, curadores, historiadores e teóricos da arte, são fundadores Walter Zanini, Aracy Amaral, Daisy Peccinini (minha orientadora de mestrado), Lisbeth Rebollo Gonçalves (minha orientadora nesta tese), Frederico de Moraes, Sônia Salzstein, Maria Amélia Bulhões, Tadeu Chiarelli, Martin Grossmann, Ana Maria Belluzzo, Maria Lúcia Bastos Kern, Ana Mae Barbosa, entre outros77. Daisy Peccinini nos lembra de

\footnotetext{
74 A área é composta também pelas subáreas da Música e das Artes Cênicas (Teatro e Dança), que da mesma maneira que a ANPAP criaram as suas associações. A Associação Nacional de Pesquisa e Pós-Graduação em Música (ANPPOM) foi criada em 1988, e a Associação Brasileira de Pesquisa e Pós-Graduação em Artes Cênicas (Abrace) em 1998.

75 Silvio Zamboni, A pesquisa em Arte, 1998, p. 6.

76 Walter Zanini, Elementos sobre a pesquisa em Artes Plásticas no Brasil e ANPAP (1987-1989), p. 37.

77 Maria Beatriz Medeiros, 2001-2004: uma longa e divertida jornada de doação, isto é, de "experiência de liberdade", 2008, p. 83.
} 
que o surgimento da ANPAP se deu dois meses depois da instalação da Assembleia Nacional Constituinte ${ }^{78}$, dentro do processo de redemocratização do país, depois de um terrível período para a liberdade de expressão e o pensamento, demonstrando que tal momento histórico para as Artes estava "em consonância com o zeitgeist, o espírito do tempo que varria a nação". Deste modo, pode-se dizer que o processo de desenvolvimento da pesquisa artística na universidade brasileira, iniciado no começo dos anos 1970, aconteceu como uma batalha subterrânea às imposições repressivas da época, contando não só com os esforços dos críticos, historiadores e teóricos das Artes, mas também dos próprios artistas. Peccinini continua, dizendo que "A ANPAP nasceu como fruto de uma mística em relação ao desenvolvimento da pesquisa das artes, contaminando em definitivo todos os que se propuseram a trabalhar por sua expansão coletiva, isto é, todos os que participaram e participam da associação"79.

Dada a grande dificuldade sobre o tema entre artistas, professores, alunos e os dirigentes de pró-reitorias, e tendo em vista a história e o conhecimento adquirido, Silvio Zamboni defendeu sua tese de doutorado em 1993 na ECA-USP, intitulada A pesquisa em arte: Um paralelo entre arte e ciência, que veio a ser publicada em 1998, preenchendo a lacuna de definição de parâmetros sobre o que é a pesquisa em criação artística. Zamboni diz que havia o Mestrado em Artes na ECA-USP, mas ainda não se sabia o que era a pesquisa em arte, sem referência de outros cursos que pudessem servir de parâmetro. Buscando traçar metodologias para a pesquisa do artista na universidade, o autor mapeou e analisou dissertações e teses prático-teóricas de artistas defendidas pela ECA-USP - as que estavam incorporadas na biblioteca à época ${ }^{80}$, de fato o acervo mais antigo da pesquisa em arte no Brasil. $\mathrm{O}$ trabalho de Zamboni foi muito importante para explicar e defender o modo de trabalho da pesquisa do artista diante das agências de fomento e dentro das

$78 \mathrm{O}$ resultado da assembleia foi a Constituição Brasileira, também chamada de "Constituição Cidadã", promulgada em 5 de outubro de 1988.

79 Daisy Peccinini, Crônica dos primeiros tempos da ANPAP (1985 - 1991 2017), 2017. Texto atualizado pela autora, publicado originalmente em: Analice Pillar et al. (org.), Pesquisa em artes plásticas, 1993, pp. 17-20.

80 Silvio Zamboni, A pesquisa em arte, 1998, p. 6. 
universidades brasileiras, inclusive a fim de imaginar uma metodologia para o fazer artístico mais próxima das Ciências, também para tentar criar um processo de trabalho para os artistas-pesquisadores, artistas que desenvolvem obras de arte baseadas em pesquisa dentro de programas de pós-graduação, futuros mestres e doutores.

\section{Artistas-pesquisadores espalhados pelo país}

Hoje, em 2018, existem 16 universidades com programas de pósgraduação em Artes Visuais, avaliados com nota acima de 3 pela CAPES ${ }^{81}$, com linhas de pesquisa próprias para a produção artística ${ }^{82}$, sendo que em 12 destas universidades esses programas são compostos de doutorados e mestrados USP, Universidade Estadual de Campinas (Unicamp), Universidade Federal do Rio de Janeiro (UFRJ), UFRGS, Universidade Estadual Paulista (Unesp), UFBA, UnB, UFMG, Universidade Federal de Goiás (UFG), Universidade do Estado de Santa Catarina (Udesc), Universidade do Estado do Rio de Janeiro (Uerj) e Universidade Federal do Pará (UFPA) - e em quatro apenas mestrado Universidade Federal Fluminense (UFF), UFSM, UFPel e Universidade Federal do Ceará (UFC). Cada programa de mestrado e/ou doutorado em Arte possui termos e organização próprios para definir a pesquisa do artista na universidade, ou seja, não existe nomenclatura única. Por exemplo, o Programa de Pós-Graduação em Artes Visuais da ECA-USP possui duas áreas de concentração ${ }^{83}$, a primeira é "Teoria, Ensino e Aprendizagem da Arte", a outra chama-se "Poéticas Visuais", área de concentração que delimita um lugar privilegiado da criação do artista visual enquanto pesquisador dentro da Universidade de São Paulo. Divide-se em duas linhas de pesquisa: "Processos de Criação em Artes Visuais" e "Multimeios", este último para dar conta da arte tecnológica, uma divisão de terreno dentro da própria arte contemporânea, com

${ }^{81}$ CAPES, Resultado da Avaliação Quadrienal 2017.

${ }^{82}$ Segundo informações contidas nos sites dessas instituições, com acesso em janeiro de 2018.

83 Segundo a hierarquia estabelecida pela CAPES, linhas de pesquisa formam a(s) área(s) de concentração, que por sua vez forma $(\mathrm{m})$ o programa de pós-graduação. Além do programa em Artes Visuais, a ECA possui programas em Artes Cênicas, Ciência da Informação, Ciências da Comunicação, Meios e Processos Audiovisuais, e Música. 
grande importância histórica, não só em termos acadêmicos, mas para a arte brasileira. O Instituto de Artes da Unicamp (IA-Unicamp) institui o Programa de Pós-Graduação em Multimeios em 1985, e o de Artes Visuais em 1989. Este último contém a linha de pesquisa chamada "Poéticas Visuais e Processos de Criação". Ambos os programas formaram uma geração de artistas e tiveram em seu quadro professores importantes para a pesquisa em arte como Julio Plaza e Paulo Laurentiz. Deve-se lembrar também o fato de Waldemar Cordeiro ter ajudado a criar o Instituto de Artes, além de ter dirigido o "Centro de Processamento de Imagens", criado por ele, em colaboração com cientistas ${ }^{84}$. O programa da EBA-UFRJ surgiu em 1985 somente como Mestrado em História da Arte, mas depois foi expandido, contando com a ajuda do artista Carlos Zilio $^{85}$, e atualmente abriga duas linhas para a pesquisa do artista, uma que se chama "Linguagens Visuais" e outra mais próxima da arte tecnológica e dos novos meios, chamada "Poéticas Interdisciplinares", tanto em mestrado quanto em doutorado. "Poéticas Visuais" no IA-UFRGS, como na ECA, é uma área de concentração que faz parte do Programa de Pós-Graduação em Artes, cujo mestrado existe desde 1991 e seu doutorado desde 1998. Possui duas linhas de pesquisa para o artista: "Desdobramentos da Imagem" e "Linguagens e Contextos de Criação". No Instituto de Artes da Unesp, em São Paulo, o mestrado em Artes existe desde 1991 e o doutorado desde 2011, contando com uma linha própria para o artista chamada "Processos e Procedimentos Artísticos". O Mestrado em Artes da EBA-UFBA teve início em 1992 e obteve o credenciamento da CAPES em 1999, depois de uma reestruturação, e o doutorado em 2013, com uma linha de pesquisa de produção artística chamada "Processos Criativos nas Artes Visuais". Na UnB, o Programa de Pós-Graduação em Arte existe desde 1994, com início do doutorado em 2008, que possui linhas

\footnotetext{
84 Antes da pesquisa em arte e tecnologia ser estabelecida na universidade brasileira, Waldemar Cordeiro, figura-chave da Arte Concreta Paulista, começou em 1968, com Giorgio Moscati, professor de Física da USP, um trabalho de investigação sobre as possibilidades de criação de arte gerada por computador, na época um IBM 360/44. Tal engajamento o levou a organizar a exposição Arteônica - O uso criativo dos meios eletrônicos em arte, na FAAP, em 1971. Ver: Cristina Freire. Arte conceitual, 2006, pp. 29-30.

85 Ver sobre a atuação crítica, discursiva e de pesquisa de Carlos Zilio em: Martha Telles e Fernanda Torres, A relação entre crítica e produção na formação de um pensamento contemporâneo de arte no Brasil na década de 1970, 2017.
} 
específicas para o artista-pesquisador em Artes Visuais como "Arte e Tecnologia", "Poéticas Contemporâneas" e "Métodos e Processos em Arte Contemporânea”. O Programa de Pós-Graduação em Artes da EBA-UFMG teve o início do mestrado em 1995 e do doutorado em 2006, com uma única área de concentração, Artes, e seis linhas de pesquisa, sendo as linhas dos artistas visuais “Artes Plásticas, Visuais e Interartes" e "Poéticas Tecnológicas”. Na UFG, o Mestrado em Arte e Cultura Visual teve início em 2003 e o doutorado em 2013, contando com a linha de pesquisa "Poéticas Visuais e Processos de Criação". O Centro de Artes da Udesc (Ceart) possui Mestrado em Artes desde 2005 e doutorado desde 2013, com a linha de pesquisa "Processos Artísticos Contemporâneos". O Mestrado em Artes Visuais da UFSM começou em 2007, e suas linhas de pesquisa não fazem distinção entre produção e reflexão. O Programa de Pós-Graduação em Artes da UFPA iniciou o mestrado em 2008 e o doutorado em 2016, com uma linha apropriada para o artista-pesquisador, chamada "Poéticas e Processos de Atuação em Artes". O Mestrado em Artes da UFPel existe desde 2012 e também contempla a produção artística. O Mestrado em Artes do Instituto de Cultura e Arte da UFC (ICA-UFC), iniciado em 2013, permite a pesquisa de produção artística em suas duas linhas de pesquisa "Arte e Processo de Criação: poéticas contemporâneas" e "Arte e Pensamento: das obras e suas interlocuções". O Mestrado em Artes na Escola Guignard da UEMG, em conjunto com a Escola de Música, começou em 2015 e tem a linha de pesquisa "Dimensões teóricas e práticas da produção artística". Também deve ser citado aqui o programa de Comunicação e Semiótica da Pontifícia Universidade Católica de São Paulo (PUC-SP), criado em 1970 primeiramente como Teoria Literária, muito importante por ter abrigado os poetaspesquisadores Haroldo de Campos e Décio Pignatari, e mesmo não sendo um doutorado em Artes, formou gerações de artistas-pesquisadores, em propostas interdisciplinares ou em relação com a tecnologia. RB entrou recentemente como orientador do Mestrado em Estudos Contemporâneos das Artes na UFF, antigo Ciência da Arte, programa iniciado em 1995, e é também orientador de mestrado e doutorado no Programa de Pós-Graduação em Artes da Uerj, existente desde 2005. JMB é professor do Instituto de Artes da Uerj desde 2015. 
Além de tornar as áreas de História, Teoria e Crítica de Arte institucionalmente mais sólidas, o grande ineditismo desses novos programas de pós-graduação em Artes Visuais foi permitir integrar dentro de sua organização um lugar específico para a pesquisa de criação do artista, em modo de convivência com outros tipos de pesquisa sobre a arte ${ }^{86}$, e permitir que os graduados em artes visuais continuem uma formação mais aprofundada orientada ao ensino superior e à pesquisa. Em 1993, quando Maria Amélia Bulhões publicou o texto "A pós-graduação e a pesquisa em artes plásticas no Brasil", havia somente um doutorado em Artes Visuais no Brasil, ainda o curso pioneiro da ECA. No texto, Bulhões fala sobre a defasagem que existia nas Artes Visuais, de forma geral, em relação a outros cursos de pós-graduação, ao mesmo tempo que alertava para a necessidade do desenvolvimento da pesquisa do artista em cursos de mestrado e doutorado. Ela diz que os artistas formados, por essa época, não estavam tão interessados em continuar sua formação acadêmica como pesquisadores e que havia um maior número de pesquisas em outras áreas das Artes Visuais. "Contribui para isto a estreita ligação que o Brasil tem tido nas últimas décadas com o sistema de ensino norte-americano, onde a formação máxima para o artista plástico na maioria das universidades é Master of Fine Arts" ${ }^{87}$, um diploma que não qualifica o artista para ser pesquisador no modelo brasileiro. Mas a autora diz que havia esforços realizados pela comunidade acadêmica em torno da ANPAP e que os resultados positivos surgiriam em breve. $\mathrm{E}$ foi o que aconteceu, tendo em vista a quantidade de exemplos explanados. Fazendo um salto no tempo de 25 anos, destaca-se aqui um artigo sobre a pesquisa artística no Brasil publicado em 2018 no Journal for Artistic Research (JAR), dos artistas Gilbertto Prado, Milton Sogabe, Yara Guasque ${ }^{88}$, que fazem um panorama retrospectivo - próximo do que foi empreendido neste capítulo - sobre a formação e o crescimento inicial dos

${ }^{86}$ Nesta tese o foco recai sobre a pesquisa do artista visual na universidade, de modo que a pesquisa não foi expandida para casos de mestrados e doutorados que tenham como resultado final, além de uma dissertação ou tese, produções em Design, Comunicação, Dança, Música, por exemplo.

87 Maria Amélia Bulhões, A pós-graduação e a pesquisa em artes plásticas no Brasil, 1993, p. 99.

88 Gilbertto Prado, Milton Sogabe e Yara Guasque, Breve História - Artistic Research in Brazil, 2018. 
programas de Artes Visuais. O texto fala sobre o incentivo alcançado a partir do desenvolvimento da ANPAP e da validação obtida junto ao CNPq e a CAPES, que além de dar auxílios e bolsas dentro do país, possibilitou que vários artistas fizessem doutorados em outros países. O texto também indica a conexão que havia entre os artistas-pesquisadores brasileiros e a Université Paris 1 Panthéon-Sorbonne, universidade que já vinha discutindo a pesquisa poética do artista, e relembra os esforços de orientadores como Arlindo Machado, Julio Plaza e Lucia Santaella, que acolheram uma geração de artistas como orientandos, principalmente aqueles que, entre os anos 1980 e 1990, se aproximavam das novas tecnologias. A evolução e a consistência da pesquisa em e sobre arte no Brasil são evidenciadas, assim como a demanda por formação de um número crescente de artistas e outros profissionais da Arte, no momento em que são citados dados da CAPES sobre a quantidade de programas funcionando em 2018 ${ }^{89}$. Lucia Leão fala, em um texto de 2016, sobre os vários livros, artigos e simpósios que vêm sendo dedicados a discutir a pesquisa do artista na universidade, tanto no Brasil quanto no mundo, "embora o debate tenha se intensificado nos últimos anos devido ao aumento de cursos de pósgraduação"90, não só em Arte mas também em Design, Multimeios e outras áreas criativas. Segundo Milton Sogabe ${ }^{91}$, conforme a pesquisa em arte avança na universidade e nos grupos de pesquisa e se transforma em uma das partes de uma área de conhecimento (Linguística, Letras e Artes), começa a aparecer a partir dos anos 1980 um novo tipo de artista no Brasil, o artista-pesquisador ${ }^{92}$,

\footnotetext{
${ }^{89}$ Segundo a plataforma Sucupira da CAPES, a área denominada "Artes", composta de cursos como Artes Visuais, Artes Cênicas, Música etc., tem em 201822 programas de pós-graduação apenas com mestrado acadêmico, 7 de mestrado profissional e 28 programas mantendo tanto o mestrado quanto o doutorado. Anteriormente nesta tese, foram listados os programas que possuem linhas de pesquisa de produção em Artes Visuais. Ver: Plataforma Sucupira. Cursos avaliados e reconhecidos - Artes, https://sucupira.capes.gov.br/sucupira/public/consultas/ coleta/programa/quantitativos/quantitativoAreaConhecimento.jsf?areaAvaliacao=11.

90 Lucia Leão, Memória e método, 2016, p. 118.

${ }_{91}$ Milton Sogabe faz parte do grupo de arte tecnológica SCIArts (Sistema de Controle de Informações de Arte), com o engenheiro e físico Fernando Fogliano, a artista Rosangella Leote e o matemático Renato Hildebrand, entre outros participantes.

92 Milton Sogabe utiliza a expressão "pesquisador-artista”. Já a expressão "artista-pesquisador" é utilizada por RB, conectada à ideia de artista-etc., e também por Annateresa Fabris em texto de 1991. Ver: Annateresa Fabris, A pesquisa em artes visuais, 1991, pp. 12-19; Ricardo Basbaum. $\mathrm{O}$ artista como pesquisador, 2013, pp. 193-201 (publicado originalmente em 2006 na revista Concinnitas, v.1, $\mathrm{n}^{\mathrm{O}}$ 9, da Uerj).
} 
que constrói uma carreira acadêmica, engajado com um novo modo de fazer da arte a partir da pesquisa, com os mesmos níveis de exigência de outras áreas do conhecimento, além de ter que cumprir certos protocolos e atividades institucionais que não eram até então atribuídas a um artista. Sogabe faz essa reflexão pontuando a diferença que há entre o artista-pesquisador que surge nos anos 1980 e a imagem do artista-professor da década de 1970, transformação de perfil que se inicia com o crescimento dos cursos de graduação em Educação Artística e Artes Plásticas até a exigência crescente para se dar aulas nas universidades públicas, do diploma de graduação ao título de doutor em Arte como pré-requisito. 93 No texto "O artista como pesquisador", RB diz que "não há como escapar desta máxima: dentro da universidade, o trabalho de arte se transforma em pesquisa e o artista em pesquisador. Escreve-se "artistapesquisador", diz ele, indicando para o aumento do número de artistas contemporâneos que atuam em várias universidades públicas pelo país:

desenvolvendo pesquisas, ministrando aulas, orientando alunos, organizando eventos e mesmo ocupando cargos administrativos. Isto pode indicar um momento particularmente favorável para a área de artes na universidade, uma vez que um número expressivo de artistas atuantes junto ao circuito de arte pode trazer, para dentro da academia, um fôlego de trabalho urdido em outras instâncias da interface arte/sociedade. 94

RB diz que hoje muitas vezes o artista já sai da graduação para o curso de mestrado, e depois para o doutorado, em um percurso dentro da universidade, e que, quando ele começou a trilhar o seu caminho como artista-pesquisador, isso não era tão comum. São artistas espalhados em universidade por várias partes do país, diz RB, que cita artistas-pesquisadores em "Rondônia, no Amapá, (...) em João Pessoa, em Recife, em Salvador, Vitória, no Rio de Janeiro, Belo 93 Milton Sogabe, Arte e pesquisa na academia, p. 23; Milton Sogabe. O ensino de artes e a formação do artista na academia, p. 35. 
Horizonte, Brasília, Curitiba, Florianópolis, Porto Alegre, artistas atuantes. Isso deve querer dizer alguma coisa" 95 .

Esta tese desloca-se acompanhando este artista-pesquisador, para quem "a presença da arte a partir da universidade" é "um caminho de ação possível - e potente - para os artistas contemporâneos" ${ }^{96}$, e no Brasil, tal como foi visto neste capítulo, essa relação demonstra-se hoje estabelecida e consolidada, pois é comprovada a quantidade e a qualidade de artistas atuantes e dos programas de doutorados em atividade. Uma história da pesquisa do artista na universidade brasileira, ou mesmo um panorama sobre o estado em que se encontra, ainda está por ser escrita, revelando as inúmeras contribuições históricas, um conjunto de nomes e episódios que precisam ser contados em outro momento dedicado somente a isso. História plural e, às vezes, de difícil apreensão, por não ficar restrita aos departamentos de Artes Visuais ou à própria universidade, por estar dispersa em vários lugares, cenas, circuitos, posições, tradições, poéticas, modos de fazer e pensar, ou seja, como uma história da própria arte.

95 Entrevista concedida por RB, localizada no Anexo 2 desta tese.

${ }^{96}$ Ricardo Basbaum, O artista como pesquisador, 2013, p. 193. 

CAPÍTULO 2

PROJETO MATÉRIA

(DE ENSINO E PESQUISA) 



\section{Funcionamento das aulas}

Em 2004, JMB foi selecionado para participar do Programa de Exposições do Centro Cultural São Paulo (CCSP)97, o que coincide com a entrada do artista no mestrado de "Poéticas Visuais" na ECA-USP, programa que já tinha uma trajetória importante sobre a pesquisa artística na universidade, como visto anteriormente. Para o CCSP o artista criou a obra de pesquisa Projeto Matéria, que pode ser definida, de forma geral, como uma oficina sobre arte contemporânea, cujo tema é o site-specific, realizada no espaço reservado ao artista, agora "transformado em uma 'sala de aula" 98 . Uma chamada pública foi aberta para a seleção dos alunos, o que resultou em um grupo de, mais ou menos, 18 pessoas. A oficina constitui-se em oito aulas ministradas em colaboração com convidados, um grupo significativo de artistas e pesquisadores emergentes da arte brasileira naquele momento, pessoas que continuarão em outros contextos e situações na trajetória de JMB.

Matéria é um nome forte, palavra com muitos usos e definições. É tanto a disciplina escolar quanto o assunto de estudo ou pesquisa; pode falar sobre substâncias, partículas e estados físicos, significar corporeidade e ocupação do espaço, indicar aspectos materiais ou imateriais da obra de arte, como a arte matérica ou a materialidade da teoria e do pensamento99, ser parte das palavras matéria-prima e material escolar etc.

JMB diz que seu papel nas aulas foi o de facilitador ou mediador, já que essas eram conduzidas pelos convidados, chamados a colaborar sobre o tema colocado e a partir dos interesses do artista sobre a trajetória de pesquisa artística ou acadêmica desses convidados à época. $\mathrm{O}$ estilo das aulas também variava, a aula de RB "foi mais participativa; a aula da Cristina Freire foi mais acadêmica, aí eu simplesmente ouvi; para a aula da Grazi [Graziela Kunsch], a

97 JMB esteve na I Mostra do Programa de Exposições 2004, que ocorreu entre 28 de abril e 30 de maio de 2004. Ernesto Neto expôs como artista convidado nesse período, junto dos outros artistas selecionados, Ding Musa, Eliana Bordin, Jailtão, Járed Domício, Maria Cristaldi e Tamara Espírito Santo.

98 Jorge Menna Barreto, Lugares moles, 2007, p. 122.

99 Sobre a ideia de "materialidade da teoria", ver: Jonathan Lahey Dronsfield (ed.), Materiality of Theory, 2011. Mais para frente na tese será visto o conceito de "materialidade do pensamento" de RB. 
gente pensou juntos"100, diz JMB. A aula da artista Carla Zaccagnini, "O texto crítico e o texto como obra", falou sobre as questões levantadas para a dissertação de mestrado da artista101, defendida naquele ano. "A desmaterialização do objeto artístico: Conceitualismo" foi o tema da aula apresentada pela pesquisadora Cristina Freire, sobre a arte de processo dos anos 1970 que pertence ao acervo do MAC-USP, objeto principal de estudo dessa pesquisadora. A aula "A escuta do site: táticas de mapeamento do lugar" foi dada por Tatiana Ferraz, artista e professora no Instituto de Artes da Universidade Federal de Uberlândia (UFU). A artista Raquel Garbelotti, artista e professora da UFES, falou em sua aula sobre "O cultivo do site: formas de pertencimento". Regina Melim, artista e professora da Udesc, discorreu sobre "A sala de aula: espaço de performação", entendendo a sala de aula também como um lugar de performance artística, onde professor e alunos participam ${ }^{102}$. No dia da artista Graziela Kunsch discutiu-se a relação entre "Registro, documentação e responsabilidade". Uma das aulas programadas, a da artista Ana Maria Tavares, que teria por tema o "site-specific deslocado", ideia defendida em sua tese de doutorado ${ }^{103}$, não ocorreu por incompatibilidade de agenda. Os encontros, que no plano original ocorreriam em dois momentos na semana, acabaram acontecendo em apenas um, o que fez o projeto exceder o período estipulado de quatro semanas da mostra no CCSP. Esse fato, aliado a problemas de agenda dos convidados, deslocou o restante dos encontros para a $\mathrm{EXO}^{104}$ e a Casa da Grazi ${ }^{105}$, espaços independentes e familiares ao artista naquela época.

100 Entrevista concedida por JMB, localizada no Anexo 3 desta tese.

101 Carla Zaccagnini, Dissertação, 2004.

${ }_{102}$ Segundo Melim, o termo performação "refere-se a performance do participador que surge do encontro entre obra e espectador como possibilidade de criação de um espaço comunicacional ou relacional". Regina Melim, Formas distendidas de performance, 2004, p. 426.

$103 \mathrm{O}$ conceito de site-specific deslocado parte da prática da artista, que diz: "A alusão aos espaços urbanos através da apropriação e do deslocamento de elementos ou de situações que remetam a esse contexto (...) tratou de transformar uma experiência antes corriqueira - a do "usuário" dos espaços públicos da cidade- em uma outra, de caráter perturbador". In Ana Maria Tavares, Armadilhas para os sentidos, 2000, p. 25.

104 EXO experimental.org foi uma plataforma de pesquisa desenvolvida por Ligia Nobre e Cécile Zoonens entre 2002 e 2007 em São Paulo, que mantinham por aquela época um espaço na Rua Bela Cintra, em São Paulo.

105 Espaço independente de exposições e residências artísticas mantido na própria residência da artista Graziela Kunsch. 
A aula de RB consistiu em uma dinâmica de grupo que é parte de sua série eu-você: coreografias, jogos e exercícios ${ }^{106}$. JMB conta que convidou RB porque ele já vinha considerando há algum tempo seus cursos e oficinas enquanto "extensões do seu exercício como artista, e não como uma atividade paralela”, e também porque Projeto Matéria procurava seguir o mesmo caminho, de "investigar cruzamentos possíveis entre o campo da arte e o do ensino da arte"107. Em e-mails ${ }^{108}$ trocados sobre esse convite para sua participação, RB diz que havia outras movimentações similares, que estavam sendo propostas para ele naquele momento, como o convite do crítico Santiago García Navarro de um projeto no Museo de Arte Latinoamericano de Buenos Aires (Malba), chamado Formas de Pensar109.

RB diz que se sentiu acolhido porque JMB incorporou no espaço da exposição essa atuação do artista-professor: "Eu percebi que ali eu não precisava sair de um papel para o outro, porque eu vi que ele tinha uma clareza sobre esse deslocamento e talvez menos conflitos sobre esses dois papéis"110, o papel do artista na universidade, como professor e pesquisador, e o papel do artista em um espaço expositivo. Em 2004, mesmo ano em que Projeto Matéria foi exibido, RB publicou o texto "Amo os artista-etc.", originalmente em inglês como "I love etc.-artists", em resposta ao projeto The Next Documenta Should Be Curated By An Artist ${ }^{111}$. A participação de RB aconteceu em um momento de

${ }^{106}$ A série é composta de dinâmicas em que dois grupos, vestindo camisetas estampadas com os pronomes "eu" ou "você", dançam ou jogam a partir de instruções e improvisações. Essas dinâmicas são filmadas e podem ser exibidas. Ver: Ricardo Basbaum e Marina Fraga, Carbono entrevista Ricardo Basbaum, 2013.

107 Jorge Menna Barreto, Lugares moles, 2007, p. 126.

${ }_{108}$ E-mails disponibilizados por JMB.

109 Segundo Navarro, o projeto reuniu produções de artistas que também se desenvolvem "nos campos de curadoria, crítica, teoria, educação, desenho de projetos, produção editorial, gestão de espaços e, de modo geral, escrita”. A exposição contou, além de RB, com os artistas Carla Zaccagnini, Karin Schneider, Francisco Ali Brouchoud e Nicolás Guagnini. Ver: Santiago García Navarro, Formas de pensar, 2004.

110 Entrevista concedida por RB, localizada no Anexo 2 desta tese.

${ }^{111}$ The Next Documenta Should Be Curated By An Artist é um projeto do curador Jens Hoffman, que convidou artistas a escrever sobre a possibilidade de a documenta de Kassel ser curada por um artista, no momento em que muitos curadores começaram a trabalhar de forma mais criativa e artistas a ser curadores. Além de RB, responderam, entre outros, Paweł Althamer, Laura Belém, Liam Gillick, Martha Rosler, Tino Sehgal e Lawrence Weiner. Um livro foi publicado em 2004 pela Revolver Press, mas as respostas estão online no site do projeto. Ver: Jens Hoffman (ed.), The Next Documenta Should Be Curated By An Artist, 2004; Ricardo Basbaum, Amo os artistas etc, 2013, pp. 167-170. 
compreensão do processo de "autoprodução do artista", diz ele, que "estava mergulhado nesse problema, de como a gente se pensa como artista"112.

Entre os dispositivos, estruturas, ferramentas e objetos utilizados por JMB em Projeto Matéria, próprios a uma oficina, estão as mesas e cadeiras emprestadas da biblioteca do CCSP, impressões em A4, folhas para rascunho, lápis e canetas, quadro-negro, projetor de vídeo, bebedouro, engradados plásticos para guardar objetos. Um pequeno armário abrigava cerca de 30 livros relacionados ao tema da oficina, entre eles One Place After Another, de Miwon Kwon; um livro organizado por Jacques Revel sobre micro-história, chamado Jogos de escala; um livro sobre microssociologia de Erving Goffman; Além dos mapas, de Cristina Freire; Distúrbio eletrônico, do Critical Art Ensemble; livros sobre Richard Serra e Cildo Meireles; o catálogo da exposição Claraluz, de Regina Silveira, que ocupou o Centro Cultural Banco do Brasil de São Paulo (CCBB SP) em 2003; o catálogo do Panorama da Arte Brasileira de 2001; a coletânea de textos sobre Arte contemporânea brasileira, organizado por RB; um dicionário inglês-português/português-inglês para uma eventual tradução ${ }^{113}$. Quem se deparava com o espaço fora dos horários da oficina, que ficava aberto ao público como as outras exposições da coletiva, tinha acesso à "sala de aula", aos folhetos de divulgação e ao vídeo de uma oficina-intervenção similar chamada "Adesão, Embate e Indiferença", que havia ocorrido em dezembro de 2003 no Espaço de Arte Contemporânea 803e804 ${ }^{114}$, um ensaio para o que depois foi desenvolvido em Projeto Matéria. Uma das paredes que delimitavam o espaço foi pintada com tinta lousa, como se fosse em uma sala de aula ou como nos quadros-negros de Joseph Beuys. A parede não era apagada depois dos encontros e exibia os vestígios do que havia se passado na aula como textos, inscrições, diagramas, palavras-chave. O artista questiona-se, em sua dissertação, se "a simples exposição da sala de aula no espaço dava transparência à complexidade do processo proposto”, mas afirma que criar uma

112 Entrevista concedida por RB, localizada no Anexo 2 desta tese.

113 Informações baseadas em imagens disponibilizadas por JMB.

$114 \mathrm{O}$ espaço funcionou entre 2003 e 2004 em uma sala comercial de um edifício no centro de Florianópolis, mantido pelos artistas Regina Melim, Raquel Stolf, Edmilson Vasconcelos e Yiftah Peled. 
experiência de aula, fazer o "deslocamento de uma sala de aula para um espaço expositivo"115 já seria um bom motivo para que uma reflexão fosse gerada. Essa reflexão acabou se estendendo para a problematização sobre restrição e especificidade do público em relação à recepção da obra pelo participante, que se tornou uma das questões importantes levantadas pela obra. Planos de ensino expostos em uma parede também podem ser considerados parte dos dispositivos, estruturas e objetos utilizados por JMB nessa obra de pesquisa. Antes das exposições principais dedicadas aos artistas, que aconteciam durante o ano, o programa do CCSP fez uma primeira grande mostra coletiva com todos os selecionados ${ }^{116}$, como uma espécie de apresentação. Sobre a ideia do que expor nessa coletiva, o artista diz que aproveitou o momento para divulgar o curso. JMB deixou disponível um folheto sobre como se inscrever para a oficina, bem como uma coleção de planos de ensino de artistas brasileiros que atuam como professores ${ }^{117}$. Esses planos, afixados em uma parede, podiam ser retirados e levados para uma mesa para consulta. $\mathrm{O}$ artista diz que nessa mostra interessou-lhe, "a partir dessa coleção, fazer um mapeamento possível da atuação do artista como professor"118.

A obra exibe o artista como professor e o participante da obra de arte como aluno, o que nos leva a pensar em vários artistas que lecionam ou lecionaram em escola de arte ou universidade, que mantêm uma vida acadêmica. O Projeto Matéria "con funde a ideia de participador de uma obra de arte com a de aluno de uma sala de aula; e a de artista com a de professor"119. Sobre os pensamentos iniciais e motivações artísticas de Projeto Matéria, JMB fala sobre a influência de Graziela Kunsch, que tem uma experiência no teatro e como professora, e sempre trabalhou de forma performática: "Foi alguma ação

115 Jorge Menna Barreto, Lugares moles, 2007, p. 125.

116 Essa exposição, chamada Coletiva do Programa de Exposições, ocorreu de 10 de março a 11 de abril de 2004 e, além dessa prévia para o Projeto Matéria, contou com obras dos artistas selecionados para o programa do ano todo, tais como Ding Musa, Jailtão, Rodrigo Matheus, Rosana Ricalde, Vitor César etc.

117 Planos de ensino reunidos na época de disciplinas como "Laboratório de criação de textos I", de Elida Tessler (UFRGS); "O espectro matérico desierarquizado como suporte da obra", de Raquel Stolf (Udesc), "A filosofia da fotografia de Vilém Flusser", de Mario Ramiro (USP), "Processos, mediações e ampliações do corpo na arte contemporânea”, de Regina Melim (Udesc). Os arquivos desses planos foram disponibilizados por JMB.

118 Jorge Menna Barreto, Lugares moles, 2007, p. 122.

119 Jorge Menna Barreto, Lugares moles, 2007, p. 125. 

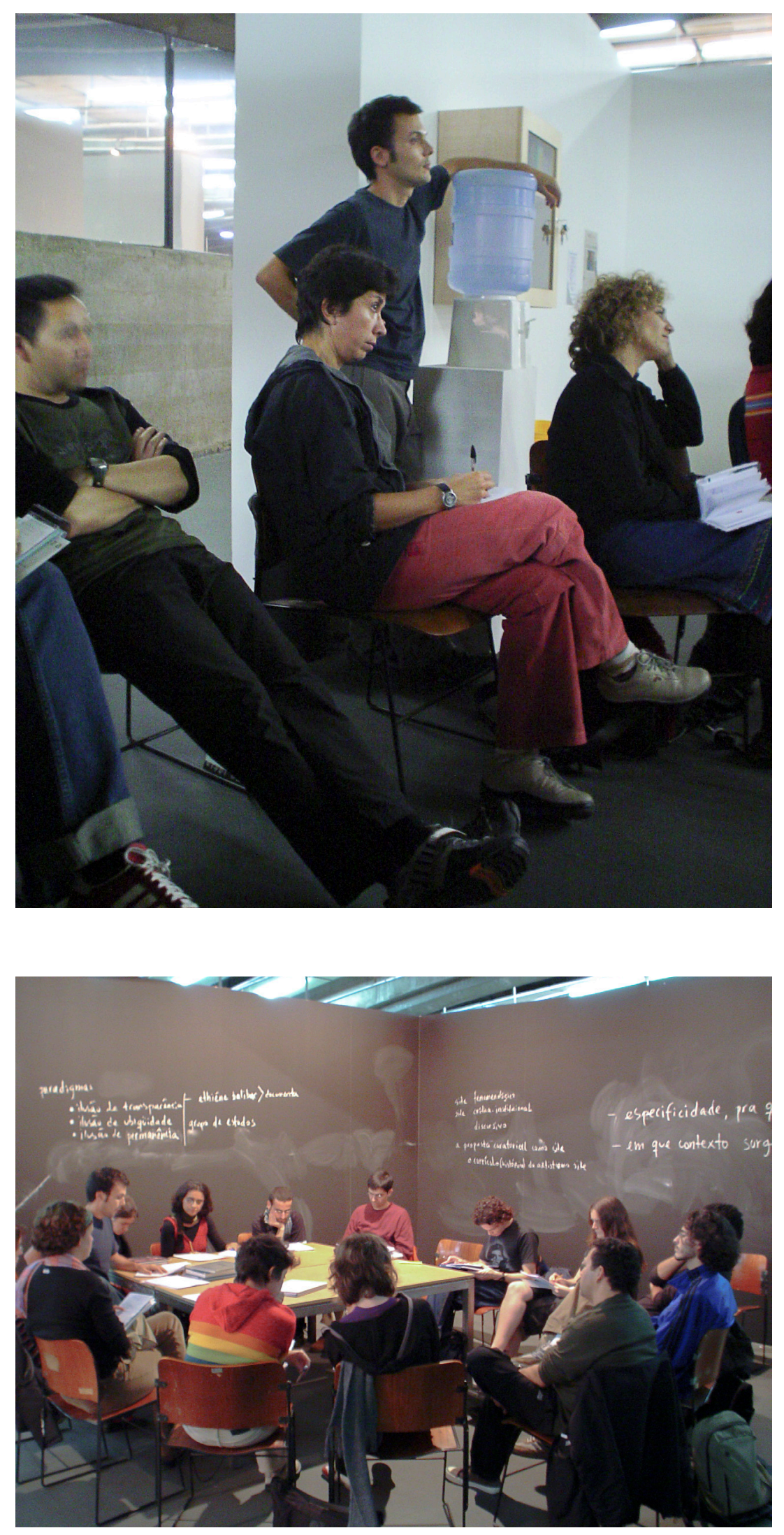

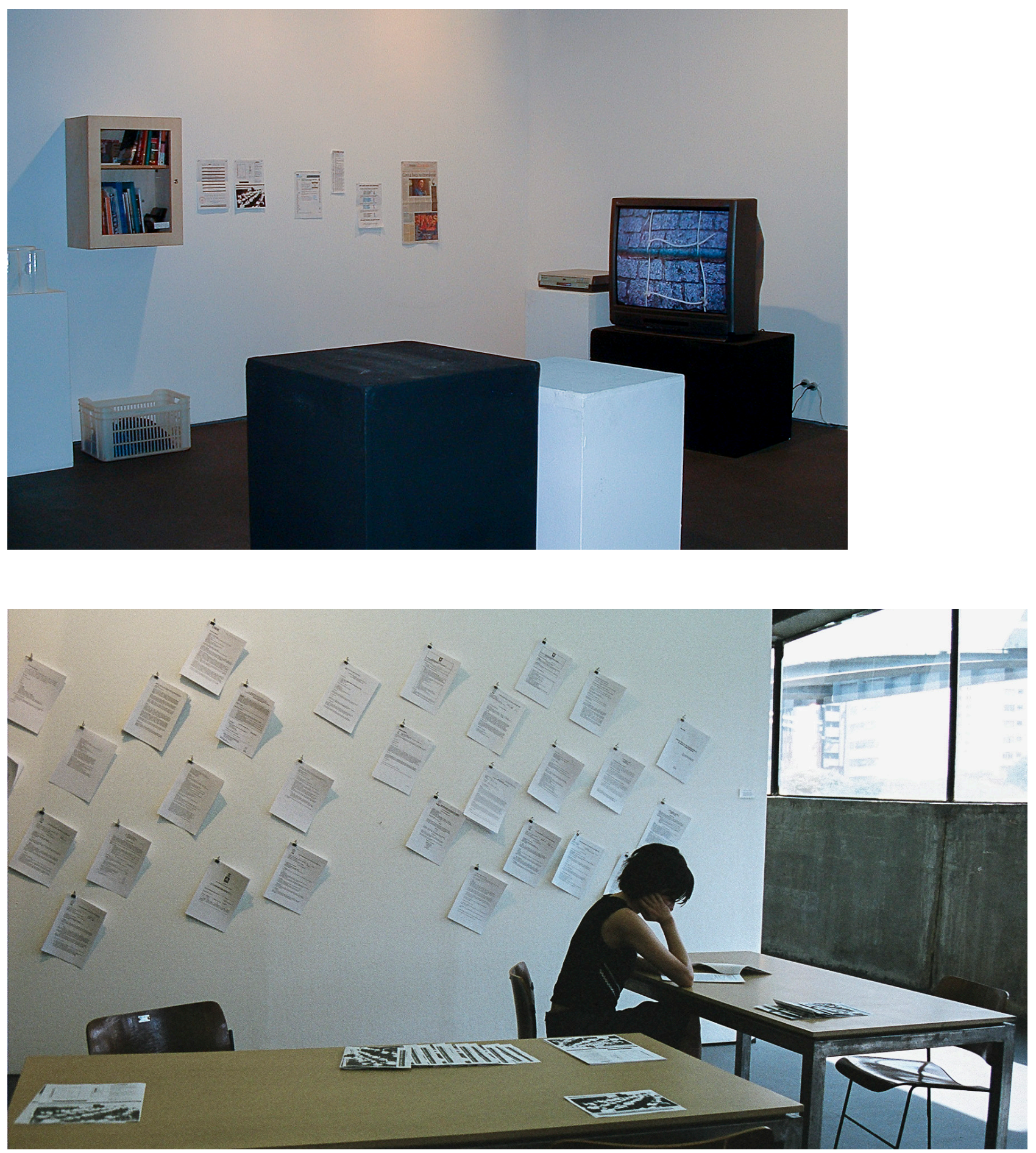

Jorge Menna Barreto, Projeto Matéria, 2004 (Centro Cultural São Paulo). 
que ela fez e que me atentou a esse lado performático e uma possível leitura estética da sala de aula. O momento da sala de aula como um acontecimento estético. E aquilo ficou comigo, acho que de uma certa maneira"120.

\section{Linha poética da educação}

Muitos artistas trataram de educação em suas obras, até o limite em que processos ou dispositivos educativos, como aulas, dinâmicas, palestras, bibliotecas e grupos de estudo, tomam parte na obra ou passam a ser a própria obra de arte. Os artistas inspiram-se no sistema de ensino, no ambiente intelectual proporcionado pelos estudos e pela pesquisa, ou apropriam-se das ações educativas e de mediação realizadas em exposições. Podemos citar alguns exemplos históricos, como: Robert Morris e sua palestra-performance 21.3, realizada em 1964, paródia em que o artista dubla uma conferência do historiador da arte Erwin Panofsky; Allan Kaprow, que participou em 1966, junto do educador Herbert Kohl, de um experimento educacional chamado Project Other Ways de educação artística para alunos da escola pública da cidade de Berkeley (CA). Kaprow também é conhecido por suas Activities, ações e experiências cotidianas como dinâmicas, realizadas a partir de roteiros feitos com a participação de seus alunos do California Institute of Arts (CalArts), e também por suas reflexões sobre a educação e a participação do público presentes nas partes 1 (1971), 2 (1972) e 3 (1974) do texto "The Education of the Un-Artist" ${ }^{21}$; Robert Filliou, que além de lançar o livro Teaching and Learning as Performing Arts ${ }^{122}$, manteve com o artista Georg Brecht o projeto-loja La cedille qui sourit em Villefranche-sur-Mer, cidade litorânea francesa próxima a Cannes, lugar em que foi desenvolvido em 1966 a Non-École de Villefranche, uma ideia de escola de arte livre; Lygia Clark, que deu aulas na Faculdade de Artes Plásticas St. Charles da Sorbonne, entre 1970 e 1976, período em que criou importantes proposições e experiências em suas aulas, que ficavam no limite com a terapia, de forma colaborativa com seus alunos, como Baba

${ }^{120}$ Entrevista concedida por JMB, localizada no Anexo 3 desta tese.

${ }^{121}$ Allan Kaprow, Essays on the Blurring of Art and Life, 1993. 
antropofágica e Túnel, em 1973; Rede de elásticos e Flor: relaxação, em 1974, Cabeça em 1975 ${ }^{123}$, que culminaram, a partir de 1978, nas sessões de Estruturação do Self; Tim Rollins desenvolveu a partir de 1981 o projeto Art and Knowledge Workshop, oficinas de arte realizadas em um centro comunitário com um grupo de crianças em situação de risco social do South Bronx em Nova York, grupo que foi chamado de KOS (Kids of Survival); Andrea Fraser, com a performance de crítica institucional ${ }^{124}$ chamada Museum Highlights: A Gallery Talk, de 1989, em que a artista se passava por uma monitora voluntária do museu, personagem fictício chamado Jane Castleton.

Joseph Beuys foi um dos primeiros a pensar as características artísticas e performáticas da aula, da palestra, do debate e também da instituição de ensino, transformando a educação em uma das linhas poéticas da obra de arte. Essas ações de caráter pedagógico desdobram sua ideia de Escultura Social/ Arquitetura Social ${ }^{125}$, no qual é articulada a crença na capacidade da arte de transformar as instituições, como a escola e universidade, e de os indivíduos moldarem a sociedade através da participação em cocriação com os artistas, produzindo juntos significados e conhecimentos através de engajamento, nos limites entre arte e vida. São suas as declarações "todo mundo é artista" e "ser professor é minha maior obra de arte”. A partir dos anos 1970, Beuys criou performances ${ }^{126}$ em que discursava e discutia temas como política e arte, tópicos como democracia, socialismo e liberdade, para uma classe ou plateia. Essas performances foram documentadas em uma série de fotografias e resultaram em lousas com inscrições, anotações, palavras-chave e diagramas, que não foram apagadas depois de utilizadas nas falas do artista. Beuys teve bastante reconhecimento em duas documentas de Kassel, colocando a pedagogia como um dos meios e materiais (políticos) do artista. Em Escritório para a

123 Eduardo Augusto Alves de Almeida, Aspectos da Estruturação do Self de Lygia Clark, 2013, p. 108.

124 Em 1971, Hans Haacke propôs o trabalho Guggenheim Museum Visitors' Profile, um questionário de pesquisa para o público do museu, com perguntas políticas ao lado de perguntas de controle estatístico, de forma pioneira como crítica institucional, porém o museu não permitiu que a ideia fosse levada adiante.

125 Joseph Beuys, I am Searching for Field Character, 1993, pp. 21-23.

126 Podemos mencionar, nesse caso, a conferência realizada por Beuys em Roma em 1971, traduzida para o português em: Joseph Beuys, A revolução somos nós, 2009, pp. 300-324. 
Democracia Direta Através de Referendo, Beuys permaneceu disponível no espaço reservado a ele no Fridericianum, no horário de funcionamento da documenta 5, de 1972, durante os 100 dias de sua duração, para discutir reforma eleitoral com o público, além de temas como a relação arte e política, capitalismo, educação, religião etc. Em 1973, com Heinrich Böll, estabeleceu a Universidade Internacional Livre para a Criatividade e a Pesquisa Interdisciplinar (FIU) ${ }^{127}$, em seu estúdio em Düsseldorf, como um local de estudo aberto e livre de expressão criativa e democrática, após ser despedido da Academia de Artes de Düsseldorf, por discordar dos parâmetros de ingresso dos alunos e por usar métodos experimentais de ensino. Em 1977, ele levou a FIU para a documenta 6 , onde realizou os 100 dias de Universidade Internacional Livre, que foi constituído de seminários, oficinas e projeções de filmes, no espaço reservado a ele, contando com a colaboração de palestrantes convidados de diversas áreas, como da política, da economia, música, pedagogia etc.

Claire Bishop coloca Beuys como uma das referências históricas mais conhecidas para os artistas contemporâneos, de exemplo de engajamento com pedagogias alternativas e experimentais, ao lado de Luis Camnitzer, Lygia Clark, Jef Geys e Tim Rollins. No último capítulo do livro Artificial Hells ${ }^{128}$, dedicado a projetos pedagógicos e a sala de aula como obra de arte, Bishop analisa as obras educativas de alguns artistas da nova geração' ${ }^{129}$ - como Tania Bruguera, com Cátedra Arte de Conducta, realizada entre 2002 e 2009; Paul Chan, com Waiting for Godot in New Orleans, de 2007; Pawel Althamer, com Einstein Class, de 2005; e Thomas Hirschhorn, exemplificado com 24h Foucault -, e

127 Ver: Joseph Beuys e Heinrich Böll, Manifesto on the Foundation of a "Free International School for Creativity and Interdisciplinary Research", 1974, pp. 49-50.

${ }_{128}$ Claire Bishop, Artificial Hells, 2012, pp. 241-274.

129 Também é importante que sejam citados aqui outros expoentes internacionais da arte que ficam no limite com a educação, como: Copenhagen Free University, que existiu entre 2001 e 2007 como um espaço independente de ensino e pesquisa mantido pelos artistas Henriette Heise e Jakob Jakobsen; Escuela Panamericana del Desasosiego, de Pablo Helguera, que em 2006 percorreu o continente americano com uma "escola portátil", em várias paradas do Alaska até a Terra do Fogo, com mostras de vídeos, mesas redondas e palestras, realizadas em colaboração com organizadores locais; e Paraeducation Department, organizado pela artista Sarah Pierce em 2004, com a curadora Annie Fletcher, que constituiu espaço informal de autoaprendizado, dentro da exposição Tracer, colaboração entre os espaços de arte contemporânea TENT e Witte de With de Roterdã. 
mostra como esses trabalhos se colocam novos e diferentes de outras práticas relacionais, ao trazerem uma abordagem pedagógica aos trabalhos.

As linhas poéticas de Beuys ${ }^{130}$, no entanto, não são as mesmas de JMB, ainda que compartilhem o interesse pela aula participativa como obra de arte e pelas relações do artista-professor com o aluno-participador. Além disso, há uma grande diferença em relação ao tom e à construção da imagem do artista. $\mathrm{O}$ estilo de Beuys de dar aula, ainda que promovendo temas não autoritários e não hierárquicos, em uma tentativa de discurso democrático, ainda se mantinha sob uma autoridade e aura mítica, em vista de sua condição de professor utópico e artista-gênio, inerente à sua própria obra e imagem ${ }^{131}$. Os artistas, nos últimos anos, vem dispensado o uso de sua pessoa como figura pedagógica central nessas experiências, criando modos mais fluidos e indeterminados de participação e colaboração, o que pode ser visto como uma das características principais do projeto poético tanto de JMB quanto de RB.

$\mathrm{O}$ uso de meios desmaterializados como palestras, aulas, discussões e encontros propiciou uma mudança de status e do lugar do fazer artístico, expandindo a noção do lugar para incluir contextos sociais e políticos. Os artistas, por uma questão de necessidade de outros espaços e engajamentos, começam a trabalhar de forma expandida, fora do estúdio e das instituições. Ocupam outros lugares que não são aqueles até então "próprios" ou convencionais à exibição de arte, como uma escola ou centro de pesquisa, ou sentem uma necessidade de subvertê-los, transformando-os de suas funções originais, trazendo a sala de aula para dentro do centro cultural, por exemplo. Desse modo, a obra de arte expande-se e intensifica-se como um campo de conhecimento, troca intelectual, debate e cultura.

Entre 2006 e 2008, ou seja, logo depois que JMB propôs Projeto Matéria, o termo "virada educacional" (educational turn) tornou-se comum para definir um fenômeno, crescente entre artistas, curadores e instituições de arte, composto de interesses muito amplos sobre os processos e dispositivos

${ }^{130}$ Ver o modo como as linhas poéticas da matéria, escultura social e educação se entrecruzam na obra de Beuys em: Dália Rosenthal, Joseph Beuys: o elemento material como agente social, 2011, p. 110-133.

${ }^{131}$ Claire Bishop, Artificial Hells, 2012, p. 244. 
educacionais. A criação do termo e a intensificação do fenômeno no contexto europeu e americano aconteceram na sequência do cancelamento da Manifesta de 2006. A bienal, que acontece cada vez em uma cidade europeia diferente e que naquele ano deveria acontecer em Nicósia ${ }^{132}$, impulsionou essas relações entre educação e arte no mundo todo. Em vez de uma exposição, o artista Anton Vidokle ao lado de outros dois curadores, Florian Waldvogel e Mai Abu ElDahab, imaginaram uma escola de arte temporária, composta de departamentos que pudessem discutir e propor modelos de transformação para a educação e a cultura na realidade daquela cidade. Contra a proliferação de bienais pelo mundo e o caráter monótono dessas exposições, que sempre ocorrem da mesma forma, os curadores pensaram na possibilidade de substituir o modelo de exposição tradicional de bienal por uma escola de arte temporária, uma escola como exposição. Sobre a problematização da participação do público nas exposições de arte, Anton Vidokle ${ }^{133}$ diz que o público é envolvido em situações em que deve participar de forma mais ativa, e isso tem ocorrido, segundo ele, com menor frequência na arte. A escola, então, seria um modelo que apontaria uma nova relação das pessoas com a arte, de forma mais engajada. A escola de arte é um lugar multidisciplinar por natureza, onde a experimentação é encorajada; lugar do conhecimento, da pesquisa, da discussão, da crítica, da colaboração e da amizade ${ }^{134}$. Não só lugar de aprendizado mas também de produção cultural, com lançamento ou edição de livros e publicações, exposições, performances, teatro; e da organização do conhecimento, o que é visto em seus acervos, arquivos e bibliotecas. A três

${ }^{132}$ A cidade de Nicósia, capital da República do Chipre, está dividida entre gregos e turcos. Os turcos ocupam a parte norte da ilha desde 1974, nomeada como República Turca do Chipre, país não reconhecido pela ONU. Até 2007 a cidade era dividida por muros e barricadas.

133 Anton Vidokle, From Exhibition to School, 2009, pp. 189-200.

${ }^{134}$ Ao final de um ensaio de Anton Vidokle sobre a Manifesta 6 há uma lista de escolas de arte e cursos experimentais, institucionalizados ou independentes, tais como Bauhaus (1919-1933), Vkhutemas (1920-1930), Black Mountain College (1933-1957), as aulas de John Cage na New School for Social Research (1956-1960), o programa Whitney ISP (1968), a Escola de Artes Visuais do Parque Lage (1975), École Temporaire de Dominique Gonzalez-Foerster, Philippe Parreno e Pierre Huyghe (1998-1999), a Proto Academy criada pelo curador Charles Esche (1998-2002) e a Future Academy, criada por Clementine Deliss (2002), entre outros. Ver: Anton Vidokle, Exhibition as School in a Divided City, 2006, p. 6. 
meses do início da Manifesta, os organizadores locais cancelaram o projeto ${ }^{135}$. Com outros artistas e teóricos que estavam no projeto, Boris Groys, Martha Rosler, Liam Gillick, Walid Raad, Jalal Toufic, Nikolaus Hirsch e Tirdad Zolghadr, a ideia foi levada de forma independente para Berlim, com o nome de unitednationsplaza ${ }^{136}$. Durante um ano realizou-se uma série de seminários, performances, conferências, palestras e projeção de filmes sobre arte contemporânea e temas políticos. A partir de então, vários museus, escolas de arte e publicações da Europa e dos Estados Unidos lançaram conferências, seminários, livros ou edições especiais de revistas para analisar o interesse tanto dos artistas quanto dos curadores e instituições sobre o tema da Educação.

"Virada educacional" é uma expressão usada para definir um fenômeno recente de movimentação da arte sobre o campo da educação e é também palavra-chave que se associa a diversas preocupações e interesses de artistas, curadores, pesquisadores e instituições de arte, tais como: processos e dispositivos educativos como obra de arte; processos de mediação entre o público e a produção artística; arte-educação; o setor educativo e de mediação em museus e exposições; museografias e curadorias pedagógicas; a educação artística; as escolas e universidades de Artes; a obtenção de títulos por parte do artista, para que ele possa dar aulas (ou ser pesquisador), dependendo do nível de ensino almejado e requerido, da licenciatura à pós-graduação stricto sensu; a criação de espaços independentes de ensino e pesquisa, entre outros tópicos. Esse fenômeno artístico ocorre através de um questionamento sobre o conhecimento na sociedade de agora disparado pelas reformas burocratizantes e homogeneizantes, orientadas a resultados quantificáveis, empreendidas nas universidades europeias a partir da Declaração de Bolonha, assunto que também está na origem do fenômeno recente da pesquisa artística e que será abordado mais adiante nesta tese.

Uma das primeiras pesquisadoras a utilizar o termo educational turn foi Irit Rogoff, professora do programa de Curadoria e Conhecimento do

135 Os organizadores locais pediram que o evento ocorresse somente do lado grego da cidade de Nicósia, o que para Vidokle seria inadmissível, por excluir o restante da comunidade.

${ }^{136}$ A escola ocupou o primeiro andar em cima de um supermercado localizado na Platz der Vereinten Nationen em Berlim. 
Goldsmiths College de Londres, no texto Turning, de 2008. Além de propor uma Estética Pedagógica, Rogoff assinala que trazer o tema da Educação por si só para o trabalho artístico ou curatorial não é garantia de uma educação livre e sem hierarquia nem de um trabalho mais ativo e eficiente de relevância crítica, entendimento ou de transformação dos espaços de exibição e interação. Contudo, por não estar sujeito a instituições acadêmicas já formatadas, o fenômeno sugere abertura e invenção de um novo espaço de participação e diálogo ${ }^{137}$. O texto faz parte da coletânea Curating and the Educational Turn, livro que reforçou a ideia de "virada educacional", organizado em 2010 pelo curador irlandês Paul O’Neill, hoje diretor no centro de arte contemporânea Checkpoint Helsinki e pelo artista irlandês Mick Wilson, hoje professor da Universidade de Gothenburg, na Suécia ${ }^{138}$.

$\mathrm{Na}$ arte contemporânea brasileira há uma quantidade significativa de artistas que trabalham sobre a linha poética da educação porém de forma independente dos debates europeus e americanos ou de forma muito desinteressada em relação a se apropriar de um termo ou definição' ${ }^{139}$. Além de JMB e RB, podemos citar como exemplos de artistas que têm obras traçadas com as linhas poéticas dos processos e dispositivos educacionais: Mônica Nador, que desenvolve desde 1996 ações artístico-pedagógicas com moradores da periferia de São Paulo, incluindo pintura criativa com estêncil em muros, debates sobre cidadania etc.; Dora Longo Bahia, que desenvolveu, em

137 Irit Rogoff, Turning, 2010, pp. 32-46.

${ }_{138} \mathrm{O}$ livro demarca a discussão, no âmbito da curadoria, sobre a virada educacional, trazendo textos de pesquisadores e artistas que perceberam, definiram e divulgaram o termo, ligando variadas práticas ao fenômeno. Para os editores O'Neill e Wilson, a educação é uma preocupação característica da curadoria contemporânea, ao trazer para o museu formatos, métodos, programas modelos e processos pedagógicos e do universo da educação ou da arte-educação. De uma forma ou de outra, o livro vai tentar explanar as práticas artísticas e curatoriais que se tornaram moda nas principais bienais, exposições, feiras de arte e seminários, ao incluir o aspecto educacional como norteador das linhas curatoriais e também de linhas poéticas da obras de arte, ou ainda daqueles casos em que não existe definição sobre ser um projeto artístico ou curatorial. Nessa tendência há uma profusão de debates, discussões, simpósios, programas educativos, debates e práticas discursivas. Paul O’Neill e Mick Wilson (ed.). Curating and the Educational Turn, 2010, pp. 11-22.

139 Uma grande exposição chamada Há Escolas Que São Gaiolas e Há Escolas Que São Asas sobre as relações entre arte e educação, com destaque para os pensamentos de Anísio Teixeira, Paulo Freire e Darcy Ribeiro, aconteceu em 2014 no Museu de Arte do Rio (MAR), com curadoria de Paulo Herkenhoff e Janaina Melo. Entre os muitos artistas incluídos, podem ser citados JMB, RB, Jonathas de Andrade, Vitor Cesar, Graziela Kunsch, Cinthia Marcelle, Elida 
Anarcademia, projeto para a $28^{\mathrm{a}}$ Bienal de São Paulo, em 2008, encontros com um grupo de alunos, com se fosse uma escola de arte, discutindo e produzindo arte contemporânea; Jonathas de Andrade, que se inspirou no método Paulo Freire de alfabetização para criar cartazes educacionais em Educação para Adultos, de 2010; Leandro Cardoso Nerefuh, que faz palestras-performance como em Arquivo Banana, de 2010, com o uso de lousa e projetor sobre conteúdos etnográficos e brasileiros; Cláudio Bueno, que desenvolveu com Tainá Azeredo o projeto Intervalo-Escola, uma plataforma de ações educativas, em colaboração com diversos artistas; inclusive com JMB e RB, que participaram na edição que ocorreu em São Paulo e no Amazonas chamada Intervalo-Escola: intervalo em curso.

No Brasil, as discussões sobre as relações entre arte e educação ocorreram, nos últimos anos, com maior frequência sobre a curadoria pedagógica e o setor educativo das instituições de arte, através da palavra-chave "mediação", e com menor intensidade sobre a análise da produção de obras de arte que têm linha poética da educação, como as exemplificadas acima. Mônica Hoff e Cayo Honorato ${ }^{140}$ estão entre os primeiros pesquisadores a utilizar o termo "virada educacional" no Brasil, para falar dos novos processos educacionais como arte ao interesse crescente sobre modos alternativos e híbridos de mediação da arte em exposições de grande porte, que partem tanto da curadoria quanto dos artistas. Hoff vai ser mais direta em sua dissertação de mestrado ${ }^{141}$, em vista de sua experiência próxima do fenômeno, já que discussões similares às europeias estavam acontecendo desde $2006 \mathrm{em}$ torno da preparação da $6^{\mathrm{a}}$ Bienal do Mercosul, e da qual foi coordenadora do projeto

140 Cayo Honorato, entre outras contribuições, analisa os novos processos de mediação desenvolvidos pelos educativos das instituições de arte ou exposição em relação às obras de arte educacionais. Ver: Cayo Honorato, A formação do artista, 2011.

${ }^{141}$ Em sua dissertação de mestrado Mônica Hoff faz um panorama do fenômeno, relacionando a situação nos EUA e Europa com o Brasil, questionando o que levou artistas, nestes últimos anos, a pensar em exposições de arte como se fossem escolas, ainda que temporárias, ao mesmo tempo que curadores passaram a atuar numa perspectiva educacional, dentro e fora das instituições. Além da própria Bienal do Mercosul como uma bienal pedagógica, Hoff faz um recorte de análise com dois outros exemplos brasileiros, os Domingos de Criação, eventos artístico-educativos experimentais ocorridos no MAM do Rio de Janeiro em 1971, organizados por Frederico Morais; e o Café Educativo de JMB. Ver: Mônica Hoff Gonçalves. A virada educacional nas práticas artísticas e curatoriais contemporâneas e o contexto de arte brasileiro, 2014. 
pedagógico. A autora diz que no Brasil o uso do termo ou a percepção do fenômeno aconteceu em um processo mais lento e de forma menos clara. ${ }^{142}$ Isso não quer dizer que não tenha havido um interesse ou que o artista brasileiro não tenha lidado com a educação em seus trabalhos nesse período ou mesmo anteriormente, veja o exemplo de JMB e de outros artistas citados acima. Somase a isso o fato de haver um interesse crescente em certas proposições críticas elaboradas entre os anos 1950 e 1970 no Brasil, descobertas ou valorizadas não só aqui mas também por artistas, teóricos e curadores do mundo todo. Nesse sentido, pode-se elencar referências como a Pedagogia do Oprimido de Paulo Freire, o método do Teatro do Oprimido de Augusto Boal, a arquitetura de espaços participativos e comunitários de Lina Bo Bardi. Além disso, há uma contribuição brasileira fundamental, expandindo essa ideia de educação para o pensamento da arte no campo social, que são os projetos comportamentais, ambientais e afetivos de Hélio Oiticica, Lygia Clark e Lygia Pape, artistas que passam ao largo das definições únicas.

RB desenvolveu uma relação entre os circuitos da arte e a universidade, sendo a produção de pensamento uma das questões mais importantes do seu trabalho. Ele diz que muitos curadores e críticos reconhecem no trabalho dele uma relação com o campo da educação, e em muitas exposições ele foi chamado mais pelo educativo do que pela curadoria da exposição. $\mathrm{O}$ artista diz reconhecer a importância das relações da arte com a educação, principalmente sobre seu trabalho, mas que não quer que este seja lido apenas por essa linha poética:

Eu não quero que meu trabalho seja colocado no nicho educativo, eu acho que não deve existir esse nicho. Pra mim essas questões da educação ou da pesquisa, eu tento,

${ }_{142}$ Essa percepção de indefinição e distanciamento pode ser percebida na seção "Fórum de debates", parte da dissertação de Mônica Hoff, que chama alguns artistas e/ou pesquisadores para responder algumas questões sobre o fenômeno da virada educacional. Há relatos de JMB, Valquíria Prates, Michel Zózimo, Guilherme Teixeira, Cristiana Tejo, Cayo Honorato, Lilian Maus, Luísa Kiefer, Fernanda Albuquerque, Jociele Lampert, Felipe Prando, Beto Schwafaty e Cristina Ribas. Mônica Hoff Gonçalves. A virada educacional nas práticas artísticas e curatoriais contemporâneas e o contexto de arte brasileiro, 2014, pp. 154 e 219. 
na medida do possível, trazê-las pra dentro da construção de linguagem, do dispositivo que é o meu trabalho. ${ }^{143}$

RB diz que que a questão das oficinas aparecem em duas séries que ele desenvolve, eu-você: coreografias, jogos e exercícios e conversas-coletivas. O artista diz que tem interesse nessa prática artística que se dá a partir da oficina, porque existe uma transformação na relação entre artista e público, que começa a acontecer de forma mais direta e horizontal, tendo em vista um trabalho coletivo. "E aí também se misturam vários outros modos de prática, como por exemplo o modo da produção de discurso, a conversa - a oficina é um lugar de leituras, de escrita, de trocas ${ }^{144}$." O artista diz que esses trabalhos não precisam necessariamente de uma exposição, no sentido tradicional, ou de um outro momento, que não seja aquele da própria oficina, para que a obra funcione e aconteça, a ação realizada já é suficiente para que essas oficinas sejam consideradas obra. De qualquer modo, RB acaba criando modos e dispositivos para que essas oficinas sejam exibidas, sendo um modo muito comum a apresentação ao público dos vídeos, daí esses trabalhos acabarem se constituindo por duas camadas de experiência, aquela que acontece dentro do grupo, "de troca, de compartilhamento, de colaboração; e outra, mediada pelo formato expositivo ou qualquer outro formato de distribuição em que posso lançar o trabalho para um público maior" 145.

A tese de doutorado Acts of Research, de Sidsel Nelund ${ }^{146}$, professora e pesquisadora na Real Academia de Belas Artes da Dinamarca, estuda como a ideia de conhecimento vem sendo trabalhada de modo intenso nas Artes Visuais dos últimos anos, e no momento em que a palavra-chave "produção do conhecimento" começa a fazer parte do discurso artístico, a partir de três nós poéticos: 1) a pesquisa artística; 2) a curadoria de pesquisa e 3) as relações da arte com a educação, ou o que ela chama de pesquisa educacional:

143 Entrevista concedida por RB, localizada no Anexo 2 desta tese.

144 Ricardo Basbaum e Marina Fraga, Carbono entrevista Ricardo Basbaum, 2013.

145 Ricardo Basbaum e Marina Fraga, Carbono entrevista Ricardo Basbaum, 2013.

${ }^{146}$ Sidsel Nelund também é diretora do Instituto de Arte, Escrita e Pesquisa, criado em 2015, também na Real Academia de Belas Artes da Dinamarca. 
A pesquisa é visível na obra de arte, objeto teórico que exige teorização por parte do observador. (...) Existe uma tendência em direção a um método de pesquisa curatorial contextualizada e responsiva à arte. Projetos educacionais combinam atos de pesquisa com processos de aprendizado ${ }^{147}$.

A autora tenta entender por que artistas, curadores e teóricos da arte começam a utilizar o conceito de "produção do conhecimento", originalmente utilizado pelo discurso neoliberal, já que o termo tem origem nas ideias sobre o valor econômico e ideológico da educação e da pesquisa da Escola Austríaca, em nomes como Friedrich Hayek e Fritz Machlup, e que estará na base das ideias de produção do conhecimento, tal como foi estabelecida no influente livro de 1994, The New Production of Knowledge: Dynamics of Science and Research in Contemporary Societies, de Camille Limoges, Helga Nowotny, Peter Scott, Martin Trow e do sociólogo brasileiro Simon Schwartzman, e que serviu de inspiração para grandes reformulações do ensino e da pesquisa em vários países ${ }^{148}$. Ela fundamenta a ideia de "atos de pesquisa" como uma prática, um processo e uma metodologia de trabalho para a arte, no caminho dos filósofos Paolo Virno, Gilles Deleuze e Félix Guattari. A autora diz que os atos de pesquisa (artística, educacional ou curatorial) estão apoiados em regras, modos de produção preestabelecidos e em regimes hegemônicos de conhecimento, porém a arte deve subverter esses parâmetros e, de forma crítica, apontar para os limites existentes, em direção a contextos históricos e sociopolíticos. Nelund também investiga a ideia de produção do conhecimento sobre a curadoria de pesquisa ou como a pesquisa artística esteve presente em mostras como a Bienal de Havana de 1989 e a documenta 13, de 2012. A autora apresenta um posicionamento interessante sobre o fenômeno, ao enxergar essas relações da arte com o conhecimento não só pelo viés das questões institucionais da arte ou

147 Sidsel Nelund, Acts of Research, 2014, p. 264. (Tradução do autor). 
da universidade, mas também ao discutir a produção artística, quando traz trabalhos de Hito Steyer, Rabih Mroué, Otolith Group, no caso da pesquisa artística, e Cátedra Arte de Conducta de Tania Bruguera e Copenhagen Free University, de Henriette Heise e Jakob Jakobsen, como exemplos de projetos educacionais. Utilizar a palavra-chave "produção do conhecimento" foi a maneira que a pesquisadora dinamarquesa encontrou para dar conta do fenômeno da arte sobre o conhecimento, que abrange o relacionamento da arte com a pesquisa e a educação intensificado a partir dos anos 2000, e que dá origem a outras palavras-chave como "pesquisa artística", "curadoria de pesquisa", "projetos educacionais" e "práticas discursivas", também fundamentais para essa tese ${ }^{149}$.

\section{Linha poética da pesquisa}

Em muitos momentos, o fenômeno do artista-professor é o mesmo do artista-pesquisador, por isso tanto a pesquisa artística quanto a teoria de artista são linhas poéticas que devem estar em evidência nesta tese. "As aulas foram uma parte da minha vida, eu as dei com paixão. Não são de modo algum como as conferências, porque implicam uma longa duração, e um público constante, às vezes de vários anos", diz Gilles Deleuze em entrevista de 1988, concedida a Raymond Bellour e François Ewald, respondendo a uma pergunta sobre o que é dar aula. "É como um laboratório de pesquisas: dá-se um curso sobre aquilo que se busca e não sobre o que se sabe ${ }^{150}$."

Uma leitura atenta e forte dos textos de artistas de JMB e RB, principalmente de suas dissertações e teses (textos originados, inclusive, quando estes eram alunos da pós-graduação stricto sensu em Artes), revela o intrincado funcionamento de suas obras de arte. Categorizações muito rígidas que surgem a partir de viradas e movimentos artísticos acabam sendo muito amplas na tentativa de abarcar, ou antes, envelopar poéticas complexas de alguns artistas como JMB e RB, ainda que estes tenham em seus projetos

${ }_{149}$ Sidsel Nelund, Acts of Research, 2014.

${ }^{150}$ Gilles Deleuze, Conversações, 2010, p. 173. 
poéticos a linha da educação como um traço importante e evidente, com reconhecimento entre artistas, curadores e pesquisadores das artes ${ }^{151}$. No entanto, isso pode fazer com que a obra e o texto do artista sejam vistos por um único ângulo e que outras linhas poéticas acabem passando despercebidas.

Projeto Matéria tem uma imagem potente do ambiente de pesquisa e do ambiente teórico, sendo também um exemplo recente de pesquisa em arte na universidade, criada sob o impacto da entrada de JMB no mestrado em 2004. "É a primeira obra que faço já tendo ingressado no mestrado, e nela podemos perceber os influxos reflexivos que irão caracterizar os anos no programa de pós-graduação"152. JMB começou a lecionar em um curso de Artes Visuais em 2001, fato que o levou a "perceber pontos de contato e retro-alimentação entre essas duas atividades" 153 , e que na sequência o instigou a frequentar o mestrado. Mais para frente o artista reafirma essa importância: "O meio acadêmico não somente tem ocupado um lugar de destaque, como influenciado grande parte da minha produção de maneira indelével (...) gerando híbridos como o Projeto Matéria"154. JMB começou a se dar conta de como os artistas acabam sendo repetidores de metodologias de trabalho que são ensinadas na graduação e que, muitas vezes, os cursos não fornecem as ferramentas de questionamento do próprio método. Desse modo, o mestrado, para o artista, é "uma volta para a academia", uma promessa de "recuo crítico", um momento reflexivo sobre a obra de arte que se contrapõe ao modo acelerado das bienais e exposições: "Em qual outro momento do sistema da arte que a gente tem o privilégio de se dedicar a uma questão por tanto tempo? E descompactar isso. E pensar, e estender, e estirar e (...) Então, eu acho um privilégio poder ter feito um mestrado, um doutorado, um pós-doc"155. O artista diz que não teria conseguido construir seu projeto poético sem essa experiência de pesquisa artística, que se

${ }^{151}$ No caso de JMB, essas linhas poéticas da educação são mais evidentes. Podemos citar, entre muitos exemplos a esse respeito, o I Prêmio Select de Arte e Educação, do qual foi ganhador em 2017. O artista, que já atuou como coordenador do setor educativo do Paço das Artes e fez curadoria pedagógica na Trienal de Sorocaba em 2015, tem uma trajetória consistente sobre as relações entre arte e educação. Ver: Jorge Menna Barreto, Anotações sobre uma certa inclinação educativa de em uma trajetória (supostamente) artística, 2014, pp. 214-223.

${ }_{152}^{2}$ Jorge Menna Barreto, Lugares moles, 2007, p. 121.

153 Jorge Menna Barreto, Lugares moles, 2007, p. 126.

154 Jorge Menna Barreto, Exercícios de leitoria, 2012, p. 10.

155 Entrevista concedida por JMB, localizada no Anexo 3 desta tese. 
desdobrou em um espectro muito amplo de atividades, que inclui dar aulas, orientar projetos, participar em congressos e seminários, e que também se expandem para circuitos fora da universidade como, entre outras práticas, coordenar em 2007 o educativo do Paço das Artes, em São Paulo, fazer parte do corpo de críticos do CCSP, entre 2008 e 2010, ou coorganizar com Helmet Batista o programa de palestras e oficinas chamado "Máquina de Responder", dentro das atividades que o CAPACETE propôs para a $29^{\mathrm{a}}$ Bienal de São Paulo, em 2010 ${ }^{156}$. Desse modo o artista circula por um campo muito aberto de debates e questionamentos, dentro ou fora da universidade, como professor ou pesquisador, abrindo-se para o mundo exterior, para outros campos do conhecimento e para o embate com o público:

Eu acho que tem algo que me dei conta no mestrado, é como a sala de aula se torna o teu ateliê e teu processo se torna público. Então, você passa a incluir todos esses outros discursos de autores, de orientador que lê o seu texto e dos colegas que estão participando junto com você em uma disciplina de metodologia; de repente tu tens uma complexidade de vozes que te traz um estado de presentidade, porque daí você está no mundo mesmo, você está ali trazendo as suas questões íntimas para uma esfera que é pública, de discussão pública ${ }^{157}$.

${ }^{156}$ CAPACETE é um programa de residências artísticas de pesquisa fundada em 1998 por Helmut Batista, com sede no Rio de Janeiro, promovendo também oficinas e palestras. Máquina de Responder foi um grupo formado por chamada pública para acompanhar de forma crítica e teórica o programa de atividades discursivas realizadas no Teatro de Arena, em São Paulo, paralelas à $29^{\mathrm{a}}$ Bienal de São Paulo, com vários dias de debates, palestras e conversas com artistas e pesquisadores, dentro os quais são importantes para o assunto desenvolvido nesta tese: Tamar Guimarães e Kasper Akhøj, o coletivo Raqs Media Collective, Sarat Maharaj, Chus Martínez, Raimundas Malasauskas, a dupla Bik van der Pol, Suely Rolnik, Andrea Fraser, Mariana Castillo Deball, Wendelien van Oldenborgh, Raquel Garbelotti, Jimmie Durham e Maria Thereza Alves, Santiago García Navarro, Carla Zaccagnini, Milton Machado etc. Ver: Jorge Menna Barreto e Helmut Batista, Em revisão [diálogo em curso], 2012, pp. 1-12.

157 Entrevista concedida por JMB, localizada no Anexo 3 desta tese. 
A universidade é mais um lugar de atuação para o artista, lugar que permite uma associação produtiva com outros campos do saber, dando origem a pesquisas, teoria e aulas. Além de ser uma ferramenta de reflexão artística, ajuda o artista a articular conceitos envolvidos em sua obra e na obra de outros artistas, dando origem a uma atividade plural que oscila entre o poético e político. Segundo JMB, "a sala de aula também pode tornar-se um ambiente de ativismo cultural e político exercido pelo artista" ${ }^{158}$.

Em 2011, em uma fala que ocorreu dentro da série de eventos O MAC Encontra os Artistas, Graziela Kunsch alerta que a função de um museu não é só preservar obras de arte, mas permitir que reflexões sejam feitas a partir delas, e exemplifica a questão com Projeto Matéria, uma obra de arte que não gera objetos mas experiências e diálogos, questionando qual seria a melhor maneira de reexibi-la, se com fotografias, relatos dos participantes, ou como um projeto educativo do museu. "Mas como manter a atualidade crítica daquela proposição? Em outras palavras, como reinventar o próprio Projeto Matéria, como ele pode seguir existindo?” São perguntas para as quais não há respostas fáceis, diz a artista, mas é importante que os museus estejam abertos a essas questões e em diálogo com os artistas, "para pensarem juntos, se fortalecerem mutuamente" 159 .

As aulas de Projeto Matéria partiram da ideia de site-specific como tema das aulas e processo de pesquisa, um estudo para o desenvolvimento de métodos e estratégias artísticas. São problemas que resultaram em outras obras e em sua dissertação de mestrado chamada Lugares moles, defendida em 2007. A ideia de site-specific está associada geralmente a certas experiências artísticas realizadas entre os anos 1960 e $1970^{160}$, aplicando-se a obras de arte que ocupam ou transbordam para lugares não institucionais da arte, um ponto na

${ }^{158}$ Juliana Monachesi e Tatiana Ferraz. Arte e universidade - novas estratégias de reflexão, 2003.

159 Graziela Kunsch, Não caber, 2016, pp. 59-60.

${ }^{160}$ A crítica norte-americana Rosalind Krauss destaca trabalhos de site-specific de artistas como Robert Smithson, Nancy Holt, Christo, Robert Morris, Richard Serra, Walter de Maria, entre outros, através da ideia de "campo ampliado", discutindo o status tradicional da escultura e do monumento em relação à nova arte que se espalha para a natureza e se entrecruza com a arquitetura. O texto também utiliza a denominação "pós-modernismo" para a prática artística que não se define apenas por um meio, mas em relação a vários meios, como fotografia, vídeo, 
natureza ou do espaço urbano, um lugar qualquer ou com uma especificidade histórica, acrescidos ou não de contexto ou ação do artista. O próprio lugar, a partir de intervenções efêmeras ou permanentes, pode tornar-se uma obra de arte. JMB é estudioso e tradutor das ideias da crítica coreano-americana Miwon Kwon, professora de História da Arte na Universidade da Califórnia. Kwon faz a passagem da ideia de site-specific dos minimalistas para uma ideia de sitespecificity mais ampla, em que a pesquisa histórica, social ou institucional sobre o lugar tem mais importância do que as relações espaciais, materiais ou formais ${ }^{161}$. A autora diferencia o modo fenomenológico do site-specific feito nos anos 1970, exemplificado com as esculturas de Richard Serra, de trabalhos feitos a partir da década de 1980, geralmente relacionados à crítica institucional, à arte social e participativa, em uma relação mais próxima com a política, a comunidade e os movimentos sociais, em nomes como Andrea Fraser, Group Material, Christian Philipp Müller, Renee Green, Mark Dion, entre outros, em que a preponderância poética se dá sobre a discursividade do lugar, sobre um campo de operação discursiva.

A partir daí, o lugar específico expande-se para uma condição de espaço discursivo, o site se torna discursivo, até o ponto em que uma dissertação de mestrado pode ser também um lugar específico e uma obra de arte, que tem o leitor como elemento do jogo proposto por essa construção relacional e colaborativa. O artista diz que "as práticas site-specific, ou as práticas artísticas específicas para um contexto, desconstroem a ideia do lugar como um suporte neutro para a obra e o ativam como parte integrante do trabalho"162. JMB quer tornar também seu texto teórico, através de uma operação artística do tipo sitespecific, em uma obra de arte participativa, em um jogo metalinguístico em que teoria e arte se confundem. A dissertação é considerada por ele uma obra, ou antes, dobra: "Produzo sobre minha própria produção. A produção tornada objeto. Procedimento que se pretende reflexivo, crítico e revigorante. Essa dissertação é uma (d)obra"163.

${ }^{161}$ Miwon Kwon, One Place After Another, 2002.

162 Jorge Menna Barreto, Lugares moles, 2007, p. 11.

163 Jorge Menna Barreto, Lugares moles, 2007, p. 16. 
Outra artista que considera o processo de pesquisa e o resultado teórico do mestrado como obra de arte é Carla Zaccagnini, que em sua dissertação Dissertação: a obra como lugar do texto, o texto como lugar da obra, de 2004, diz que a dissertação "não caminharia se não fosse afirmando-se e questionando-se como projeto artístico e acadêmico todo o tempo, porque é esse movimento que constitui o foco da dissertação e lhe dá corpo, porque é nesse pensamento que a investigação se encerra"164. RB também sugere, em sua tese de doutorado, que um texto teórico sobre arte também pode ser arte, reconhecendo em Robert Smithson, Hélio Oiticica e Art \& Language modelos dessa articulação de visualidade e plasticidade com a teoria de artista em um texto tornado obra de arte: "Assim, em todos os seus desdobramentos, esta Tese estará procurando contabilizar alguma presença como obra em sua efetiva condição de agregado plástico-conceitual, atravessada por um campo discursivo" 165 .

Um dos capítulos de Lugares moles chama-se "Inacontecido [Mesas]", um capítulo que simula mesas redondas transcritas, oscilando entre o teórico e o fictício. O tema das mesas-redondas "mediadas" por JMB é o site-specific, como "Especificidade, para quê?", sobre práticas artísticas site-specific, "Consciência Contextual", sobre a obra de arte se dar em um contexto específico, e "A Palavra Situada", sobre os significados da palavra site-specific e sua tradução para o português ${ }^{166}$. Nas palavras do artista, é uma "escrita experimental" em que são apropriados vários trechos de textos sobre arte, com a fala de alguns artistas e teóricos da arte que foram referência para ele durante o período de pesquisa de mestrado, como Andrea Fraser, Cildo Meireles, Julio Plaza, Sarat Maharaj, Richard Serra, Rosalind Krauss, Lawrence Weiner, Robert Smithson etc. A mesa, como um dos objetos mais importantes do projeto poético de JMB, é o lugar da refeição, do estudo, da pesquisa ou do debate público, a partir dela pode-se fazer um banquete ou uma mesa-redonda, em volta da mesa começa a conversa e o convívio: "A mesa se coloca assim como um

${ }_{164}$ Carla Zaccagnini, Dissertação, 2004, pp. 106-107.

165 Ricardo Basbaum, Você gostaria de participar de uma experiência artística $(+N B P), 2008$, p. 17. 
lugar de ação, de pesquisa, de atuação performativa (...) próximo do método da conversa, e por isso a sua consequente abordagem como "falas"'167. O autor faz uma observação sobre o texto criado para essas mesas fictícias, relembrando que é uma "versão livre e experimental do discurso original, para uso específico nesta situação imaginada. Portanto, não devem ser citadas como referências historiográficas"168. São encadeadas perguntas ou mediações elaboradas pelo próprio artista e as respostas ou falas são baseadas nas referências selecionadas por ele, em um encadeamento que faz com que elas pareçam de fato ter existido. "A partir de pontos de contato entre esses textos, crio um jogo de sincronização em um tempo e espaço imaginados onde esses autores são alinhados ${ }^{169}$.” JMB inventa conversas que não ocorreram de fato, "baseadas primeiramente em textos que foram lidos, que tornaram-se falas imaginadas (conversas)", guardando ainda a veracidade das citações "transcritas ou transcriadas"170, em uma aproximação com as ideias de Haroldo de Campos $^{171}$ sobre a tradução ${ }^{172}$. No final de sua dissertação, JMB escreve uma "Resposta a Julio Plaza", ao modo de Lygia Clark em sua "Carta a Mondrian", como uma homenagem. Plaza "participou" da última mesa e perguntou sobre a caracterização poética das mesas. JMB responde, na carta, que "o lugar das mesas acontece no próprio leitor, no ato da leitura, ativado então como construtor e participador. Esta é a propriedade do sentido de inacontecido"173. Assim, eu, como leitor da obra de JMB, também participo de sua obra através da leitura e da imaginação, a partir do momento em que a leitura do texto é também considerada uma performance do leitor, que participa da obra.

JMB constrói um universo teórico, não só para dar conta da leitura de suas obras, mas também para ser parte delas: "O site-specific não é entendido somente como um tema, mas como um método de abordagem da própria

\footnotetext{
167 Jorge Menna Barreto, Lugares moles, 2007, p. 137.

168 Jorge Menna Barreto, Lugares moles, 2007, p. 160.

169 Jorge Menna Barreto, Lugares moles, 2007, p. 151.

170 Jorge Menna Barreto, Lugares moles, 2007, p. 137.

${ }_{171}$ Ver: Lucia Santaella, Transcriar, transluzir, transluciferar, 2005, pp. 221-232.

172 A tradução, como uma operação de leitura crítica sobre a tradição, tal como pensada por Haroldo de Campos, é uma preocupação recorrente de JMB, e será objeto de estudo em sua pesquisa de doutorado.

173 Jorge Menna Barreto, Lugares moles, 2007, p. 225.
} 
dissertação como um espaço específico, onde é possível propor uma operação artística"174. Na dissertação, JMB definiu, em cinco etapas, um método sitespecific: escolha do lugar e definição da situação; processo de pesquisa que se inicia com "escuta" e "mapeamento"; identificação do problema; construção da obra composta de "planejamento e realização da fala"; e, por último, o que ele chama de fissuras, um momento de crítica retrospectiva ${ }^{175}$. JMB considera o site-specificity menos como uma categoria das artes, como o desenho ou a instalação, do que como um método de trabalho. É desse modo que JMB fará depois, em sua tese de doutorado, uma atualização importante da ideia defendida em sua dissertação de mestrado sobre o site-specific, ampliando-a ao relacioná-la com a ideia de pesquisa artística, já que mais do que uma categoria, o site-specificity é uma metodologia de pesquisa artística, uma "prática de investigação", nesse caso, a usada pelo artista. O artista diz que "o termo 'pesquisa', quando utilizado em [seu] texto, deve ser lido em alta voltagem"176.

Se em Lugares moles a matéria de investigação é a ideia de sitespecificity, em Exercícios de leitoria, sua tese de doutorado, JMB fará análise de oito obras de sua trajetória artística do ponto de vista da influência ou referência, uma leitura de suas obras a partir da leitura de projetos poéticos de outros artistas. JMB diz que o insight para a ideia de sua tese de doutorado veio com a ideia de iniciação e trajetória artística, pensando como os primeiros trabalhos práticos na escola de artes ocorriam, geralmente baseados numa referência ou numa associação, feita pelo professor, de alguma obra ou artista já existente, para a leitura dos exercícios dos alunos ${ }^{177}$. Assim, as referências produziam conflito, naquele momento, sobre a possibilidade de se ter uma voz própria e ser autor. O artista diz: "Para tratar os múltiplos deslocamentos traçados entre obras, autores, textos e contextos, a tese lança mão de diferentes concepções de tradução, entendida como uma ação complexa e que reivindica visibilidade" ${ }^{178}$. Além das relações criadas por JMB do conceito de leitoria com a

\footnotetext{
174 Jorge Menna Barreto, Lugares moles, 2007, p. 3.

175 Jorge Menna Barreto, Lugares moles, 2007, pp. 27-29.

176 Jorge Menna Barreto, Exercícios de leitoria, 2012, p. 31.

177 Jorge Menna Barreto, Lugares moles, 2007, p. 14.

${ }_{178}$ Jorge Menna Barreto, Lugares moles, 2007, p. 6.
} 
angústia da influência de Harold Bloom, o decréscimo de autoria de Barthes e a tradução intersemiótica de Julio Plaza, o artista vai utilizar a ideia de projeto poético sincrônico de Haroldo de Campos, e depois desenvolvida por Julio Plaza, a partir das constelações de Walter Benjamin, para falar sobre como os trabalhos de arte desenvolvem-se sobretudo em cima do que foi criado anteriormente. Ou seja, para resolver o problema atual da leitura de obras anteriores, JMB também atualiza a concepção de tradução vinda dos poetas concretos, para criar o termo "leitoria". Leitura de uma obra original de outro autor que se transforma em algo autoral, desviando-se de maneira original. Esses autores vão mostrar que o mecanismo da "tradução" é o próprio processo de pesquisa: "O exercício começa na investigação da obra (ou aspectos dela) de um outro autor, chamada aqui de obra-original, a partir da qual construo uma obra-resposta (...) ${ }^{179}$ ". Para JMB, acompanhando o pensamento de Janneke Wesseling no livro See It Again, Say It Again: The Artist as Researcher, essa consciência do artista diante da arte feita em relação à história da arte é uma das características fundamentais da pesquisa artística: "Poder-se-ia nomear isso de 'autoconsciência' da obra de arte, que questiona e comenta a si mesma, assim como o trabalho de outros artistas"180. Aqui o artista responde a uma das questões sobre a utilização do processo de pesquisa, ou seja, o da necessidade de conhecer e pesquisar a respeito de outros artistas ou de se fazer um trabalho de arte fundamentado. Desse conflito entre a criatividade inata e um comprometimento com a história da arte, JMB lança, na esteira do artista-etc., o termo artista-leitor ${ }^{181}$. No recorte que JMB faz do artista como pesquisador, e em uma aproximação da arte com a leitura de textos poéticos ou textos teóricos, o artista é um leitor, que no meio acadêmico ou fora dele faz a leitura de livros e leitura de artistas, como um modo de traduzir as outras obras em sua própria obra. Dentro ou fora da universidade, o artista traz o processo da pesquisa para seus projetos poéticos, primeiramente como um método que ajuda na prática artística, até o momento que a obra se torna peça de um sistema complexo, composto de outras peças espalhadas e conectáveis.

\footnotetext{
179 Jorge Menna Barreto, Exercícios de leitoria, 2012, p. 37.

180 Janneke Wesseling apud Jorge Menna Barreto, Exercícios de leitoria, 2012, p. 15.

${ }^{181}$ Jorge Menna Barreto, Lugares moles, 2007, p. 16.
} 
Podemos divisar, a partir dos anos 2000, no Brasil, um período específico em que há um movimento de efervescência e crescimento do número de artistas na academia, depois de um período heroico do estabelecimento da pesquisa em arte e dos mestrados e doutorados em Artes nas universidades brasileiras, sobretudo públicas, de uma geração próxima de JMB, artistas como Carla Zaccagnini, Graziela Kunsch, Vitor César, Raquel Stolf, Cláudio Bueno, Traplev, Raquel Garbelotti ${ }^{182}$, entre muitos outros, que também se aproximaram de mestrados e doutorados, geralmente com o enfoque em questionamentos sobre o público, o coletivo, o lugar, os espaços independentes, o discursivo, o texto de artista, o contexto, a instituição, a narrativa, a participação, a mediação, a política, a cidade e a própria condição do artista-pesquisador. Tanto Projeto Matéria e outras obras de JMB, quanto a dissertação de mestrado Lugares moles, bem como sua tese de doutorado Exercícios de leitoria, contêm em si um pouco de cada um desses questionamentos. Sendo assim, o projeto poético de JMB ajuda a exibir e explicar o fenômeno da pesquisa artística na arte de agora, cuja presença se intensifica a partir dos anos 2000, até o ponto em que começa a extrapolar o terreno propriamente acadêmico em direção aos mais variados domínios e contextos.

\section{Pesquisa específica}

À medida que esta tese se desenvolvia, no período de quatro anos que compreendeu este doutorado, foram sendo acompanhados os novos sentidos que o projeto poético de JMB tomou, ou seja, o tempo desta pesquisa confundese com o da pesquisa do artista, período em que será observado uma movimentação em direção ao pensamento sobre o alimento e o meio ambiente,

182 Entre algumas teses de artistas desenvolvidas a partir de 2001, estão: Renata Lucas, Visto de dentro, visto de fora, 2008; Mario Ramiro, O gabinê fluidificado e a fotografia dos espíritos no Brasil, 2008; Raquel Stolf, Entre a palavra pênsil e a escuta porosa, 2011; Raquel Garbelotti, In(audíveis), 2011; Yiftah Peled, DTEEP, 2013; Michel Zózimo, Fluxorama, 2014; Cláudio Bueno, Campos de invisibilidade, 2015; Graziela Kunsch, Não caber, 2016. Entre as dissertações, ver: Marilá Dardot, $A$ de arte, 2003; Dora Longo Bahia, Marcelo do Campo 19691975, 2003; Traplev, Recibo 5/7, 2007; Lais Myrrha, Sobre as possibilidades da impermanência, 2007; André Severo, Deriva de sentidos, 2007; Vitor Cesar, Artista é público, 2009; Mayana Redin, Das cosmologias, 2013; Diogo de Moraes, Públicos em emergência, 2017. 
como desdobramento de seus interesses sobre o lugar da obra de arte. Em 2016, para a $32^{\text {a }}$ Bienal de São Paulo, o artista desenvolveu Restauro, um restauranteobra materializado a partir da apropriação da cozinha e do mezanino do prédio de Oscar Niemeyer e da venda de pratos compostos de ingredientes provenientes de agroflorestas.

Uma estrutura de restaurante completa foi criada durante essa exposição de grandes dimensões. Foi necessário construir uma rede de abastecimento formada só de agrofloresteiros para o restaurante, "com todas as dificuldades possíveis de escala, de negociação econômica”, diz o artista, lembrando que a "lógica de abastecimento de restaurante é mais próxima da monocultura do que da agrofloresta"183. O projeto contou com a colaboração de vários grupos e pessoas, como a Escola Como Como de Ecogastronomia e Neka Menna Barreto, que desenvolveram o cardápio e ficaram encarregados da cozinha. O espaço de convívio e o mobiliário foram pensados em conjunto com o coletivo O Grupo Inteiro, composto pelos artistas Carol Tonetti, Cláudio Bueno, Ligia Nobre e Vitor Cesar. Restauro também é composta de experimentações sonoras realizadas em colaboração com o artista Marcelo Wasem, que fez registros em áudio do campo e de entrevistas.

Um dos grandes fornecedores do restaurante temporário foi, entre outros, o Assentamento Mario Lago de Ribeirão Preto, ligados ao Movimento dos Trabalhadores Rurais Sem Terra (MST). Os cardápios eram definidos diariamente de acordo com a oferta dos produtores. O prato principal era servido em um pote, o pote paisagem, feito de camadas de vários ingredientes e preparações. "Agroflorestas são cultivadas em extratos. Cada camada captura uma faixa de luz. (...) Pensamos então em como traduzir essa experiência vertical para o ato de comer e chegamos nas comidas em potes." 184 Os potes paisagem podiam ser compostos de purê de cará roxo, vinagrete de feijão defumado, beterraba, couve marinada, purê de mandioca com curcuma, tabule com ervas, pasta de cenoura com amendoim e laranja, farofa de couve-flor e rúcula fresca, creme de tofu, beterraba caramelizada, bifum com cenoura e

183 Entrevista concedida por JMB, localizada no Anexo 3 desta tese.

184 Jorge Menna Barreto, Entrevista concedida à jornalista Marília Miragaia, 2016. 


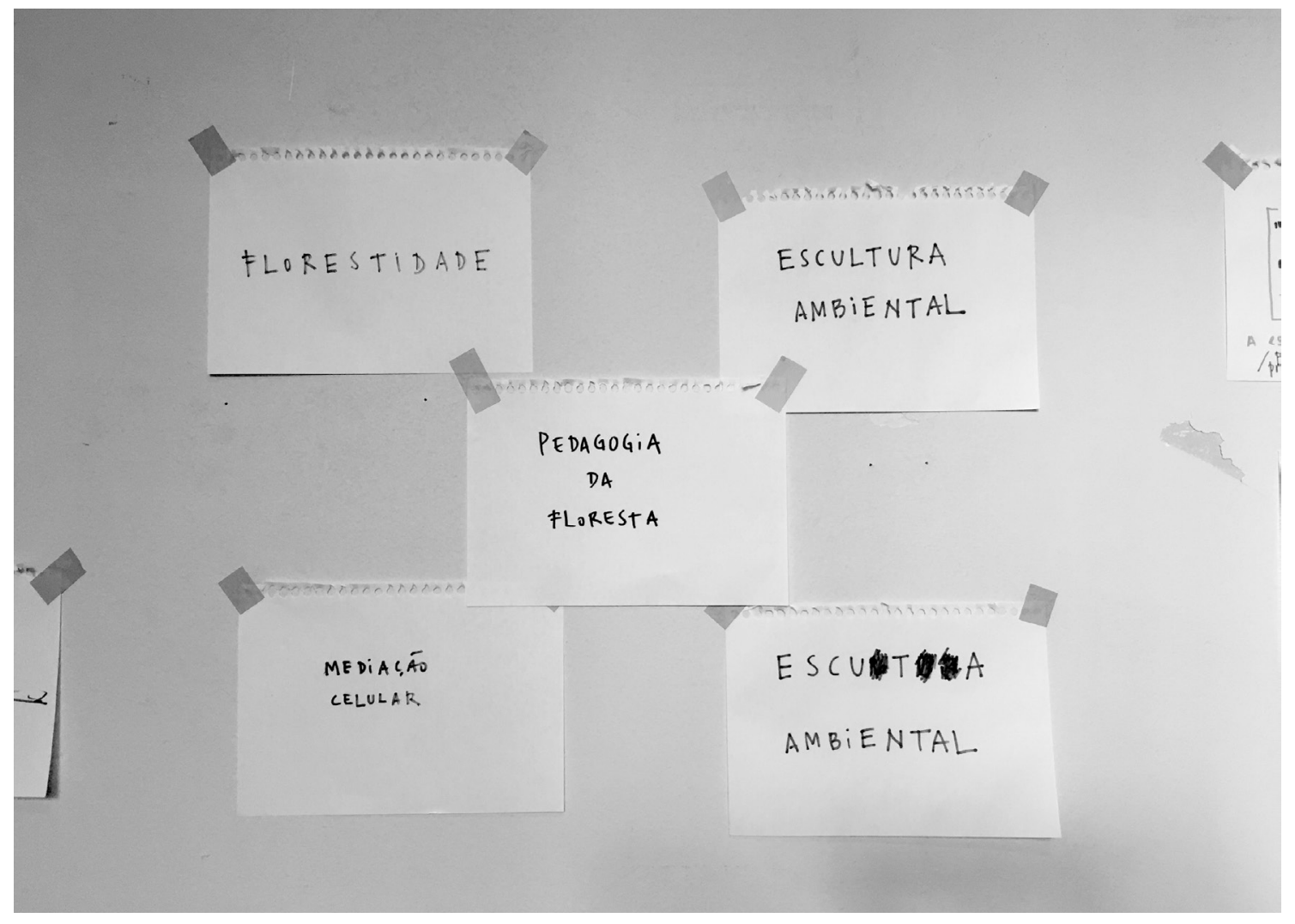

Jorge Menna Barreto, Restauro, 2016 (32 ${ }^{\mathrm{a}}$ Bienal de São Paulo)

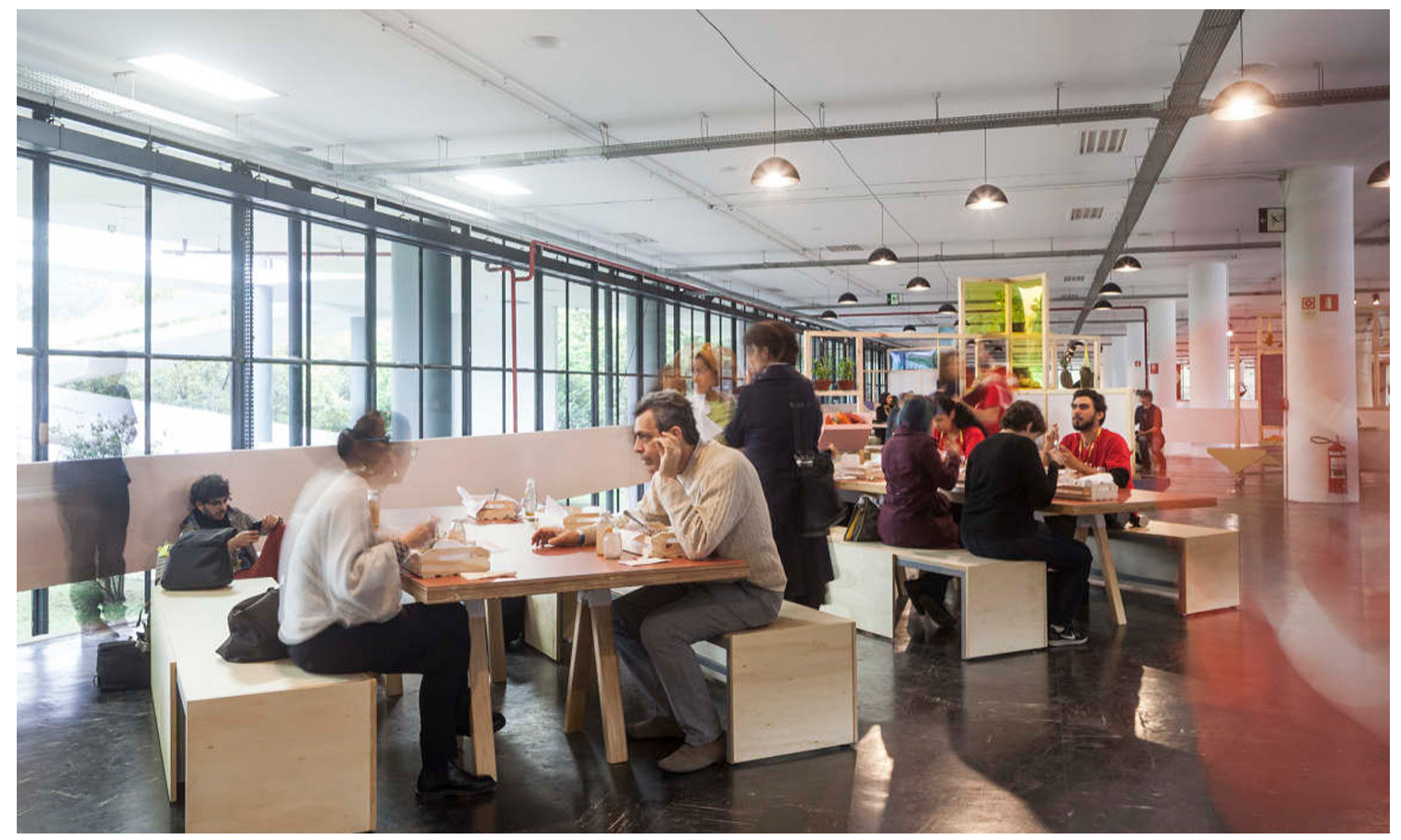



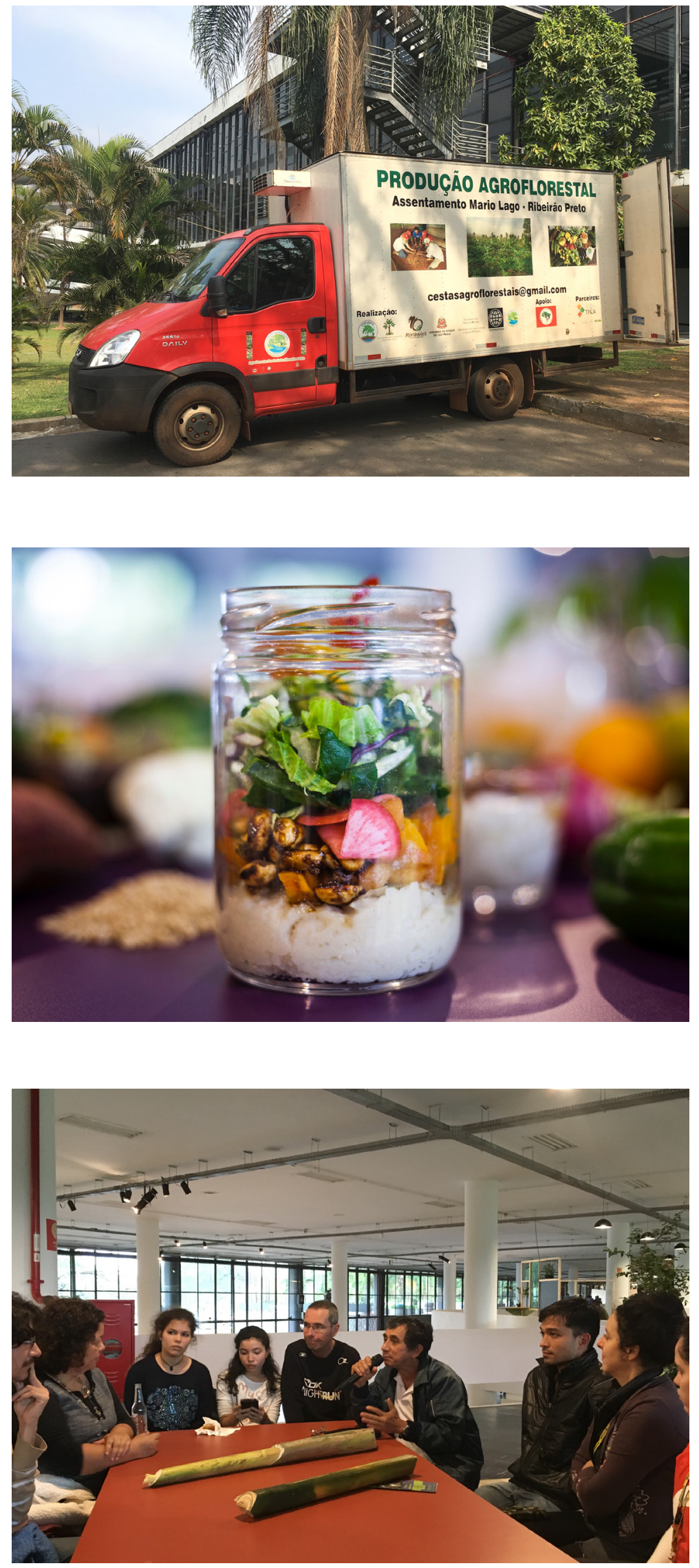
folhas verdes etc. Além do pote, havia o PF Agroecológico que, em um dos dias, foi servido com espetinho de legumes, feijão fradinho, arroz cateto, farofinha, vinagrete de caju e manga e salada de Plantas Alimentícias Não Convencionais (PANCs).

A obra foi composta também de oficinas, onde se ensinava a preparar e construir os potes paisagens, e de palestras e conversas sobre, por exemplo, produção de mudas florestais nativas em comunidade remanescente de quilombo ou do uso sustentável da palmeira juçara como estratégia de conservação da Mata Atlântica ou sobre a ONG Mutirão Agroflorestal. Também houve, ocasionalmente, a distribuição de mudas frutíferas, como o araçazeiro e a pitangueira. Parte importante dessa obra de arte são os educadores, que estavam treinados e disponíveis no espaço das refeições para falar sobre agroecologia e assuntos relacionados à exposição. $\mathrm{O}$ artista diz que não havia "uma preocupação de inserir a obra a partir de um discurso que ficasse explícito e evidente naquele momento. Então, as pessoas vinham tomar um café, iam embora e não sabiam, ou não ficavam sabendo, que aquilo era uma obra”. Essa liberdade está relacionada com o conceito de "participação celular", criado por JMB para lidar com esse novo tipo de participação que é instaurado, onde o corpo participa da obra ao consumir o alimento. E o alimento, na obra de arte, é "melhor lido pelas células do que de forma discursiva"185, diz o artista.

No tempo entre Projeto Matéria e Restauro, JMB desenvolveu muitos projetos próximos da educação e da mediação museal, em produções que ficam nas fronteiras do artístico, do discursivo e do educativo, linhas importantes do seu projeto poético, e que o ajudaram a chegar ao lugar onde ele se encontra hoje. EM 2014, o artista fez uma participação na revista Urbânia $5^{186}$, com o artigo "Anotações sobre uma certa inclinação educativa de em uma trajetória (supostamente) artística"187, que compilava e sintetizava, com diagramas e imagens, os projetos e trabalhos desenvolvidos por ele que estão no limite entre

185 Entrevista concedida por JMB, localizada no Anexo 3 desta tese.

186 A Urbânia 5 foi editada por Graziela Kunsch a convite da $31^{\text {a }}$ Bienal de São Paulo, um número sobre as novas relações entre arte e educação.

187 Jorge Menna Barreto, Anotações sobre uma certa inclinação educativa de em uma trajetória 
educação e arte, em uma trajetória que se inicia em Projeto Matéria (2004), passa pelo Grupo de Educação Colaborativa do Paço das Artes (2007), o Café Educativo (iniciado em 2008) e Desleituras (2011), até os Sucos Específicos (2014).

O Café Educativo é um espaço de convívio instalado no espaço da exposição para que as pessoas possam tomar um café, um suco, e conversar sobre a exposição, em um momento informal de mediação, em que os "garçons" do café, como educadores, são habilitados a conversar sobre a exposição. A obra, que tem sua origem em 2007 no Grupo de Educação Colaborativa do Paço das Artes, ocorreu também em 2008 no evento Arte e Esfera Pública no CCSP, e depois em várias ocasiões, e foi adquirida pelo MAM-SP em 2011.

Desleituras, por sua vez, são capachos, como tapetes de borracha de porta de edifícios, sobre os quais estão escritas palavras inventadas. Os tapetes foram utilizados pela primeira vez no $32^{\circ}$ Panorama da Arte Brasileira, em 2011. A palavras, como um erro de ortografia, são uma combinação de duas palavras existentes, como DESISTÂNCIA, SEGUEIRA, LIVERDADE, DESEXPERO, HOUVIDO, DELEITURA, INDESTINO, DESVISÃO, EUSÊNCIA, SOMIDO, MEDICACHÃO, CONMIDA, RESTORIAN, INVERÇÃO, IMARGEM etc. Na mostra no MAM, os tapetes ficavam no chão da exposição e podiam ser colocados pelo público em frente às outras 25 obras, permitindo que os participantes articulassem significados livres entre as palavras e as obras expostas, em um jogo mediado pelos educadores. Além de uma aproximação com a educação como arte, o conjunto de tapetes de Desleituras pode ser visto como um novo tipo de "texto crítico". Além de atuarem como dispositivos de mediação, as palavras assumiam o papel do texto sobre as outras obras, porém em linguagem "errada” e poética. Segundo o artista, os "sucos gástricos e metabólicos presentes em Desleituras não digeriam somente as obras e artistas presentes no $32^{\circ}$ Panorama, mas o próprio discurso mediador e sua pretensa transparência comunicativa, as mesmas velhas e gastas palavras"188. Mediar é contar com o erro e o desvio. Para o artista, o educativo de qualquer exposição não deve trazer a satisfação ou ser benevolente com o público, trazer respostas 
prontas, mas, antes, gerar conflito criativo, um incômodo que gera desejo por mais conhecimento. JMB diz que os tapetes "habitavam assim um território ambíguo, em trânsito entre obra, discurso crítico e dispositivo de mediação"189. Na conclusão da sua tese de doutorado, da qual Desleituras faz parte, o artista fala sobre o erro e o desvio como elementos necessários e constituintes da pesquisa artística, um tipo de leitura que provoca novas formas a partir da transformação do original. ${ }^{190}$

Sucos Específicos foi o primeiro projeto que JMB fez sobre agroecologia. O suco substituiu o café e outros produtos na edição do Café Educativo, que ocorreu na exposição Campo Neutral191, no Museu da Gravura Cidade de Curitiba, em 2013 ${ }^{192}$. Sucos Específicos são sucos verdes veganos, feitos de frutas e folhas de PANCs ou, como prefere JMB, "matinhos comestíveis". "Foi a primeira vez, de maneira um pouco acidental, digamos. O museu ficava do lado de uma feirinha orgânica, e eu já tinha esse interesse; então, envolvi a feirinha como fornecedora do Café Educativo"193. Como parte de sua participação no projeto Campo Neutral, foi realizada também uma oficina chamada "A Relação Entre as Práticas site-specific e a Agroecologia”, que aconteceu dentro de uma agrofloresta no norte do Paraná, chamada Cooperafloresta194. Na sequência, 200 garrafinhas de $50 \mathrm{ml}$ foram produzidas como parte do encerramento do projeto Ações Curatoriais, com curadoria de Kamilla Nunes, Beatriz Lemos e Marta Mestre, na Ilha de Anhatomirim, perto de Florianópolis, em 2014. O agrônomo Jefferson Mota auxiliou com a identificação das PANCs uma semana antes, e o artista Bil Lühmann fez cinco ilustrações para o rótulo, uma para cada matinho: tansagem, dente-de-leão, tropearaba, falsa-serralha e aroeira' ${ }^{195}$. Ainda

\footnotetext{
189 Jorge Menna Barreto, Exercícios de leitoria, 2012, p. 134.

190 Jorge Menna Barreto, Exercícios de leitoria, 2012, p. 127.

${ }^{191}$ Com curadoria de Felipe Prando, Campo Neutral contou com as participações de RB, Vitor Cesar, Traplev, Graziela Kunsch, entre outros.

192 Ver: Jorge Menna Barreto, Manual para um Café Educativo, 2014.

193 Entrevista concedida por JMB, localizada no Anexo 3 desta tese.

194 Cooperafloresta é uma cooperativa de trabalho pioneiro sobre agrofloresta, composto de famílias agricultoras quilombolas nos municípios de Barra do Turvo em São Paulo e Adrianópolis no Paraná. Agrofloresta é uma forma de criação, cultivo e produção de alimentos que se integra à floresta. Diferente da agricultura artificial e mecânica, conserva os rios e o solo, não utiliza pesticidas, preocupando-se com as relações ecológicas e a biodiversidade. 195 Jorge Menna Barreto, Deixe que o lugar determine, 2016, pp. 201-206.
} 
em 2014, mesmo ano em que desenvolvia um pós-doc na Udesc, em Florianópolis, orientado por Regina Melim, JMB apresentou Paladar Cego, obra que aconteceu dentro de uma obra de pesquisa da dupla de artistas Bik Van der Pol na $31^{\text {a }}$ Bienal de São Paulo, o programa artístico-educacional chamado Olhar para Não Ver. Paladar Cego é uma série de eventos, nos quais estavam incluídas uma edição do Café Educativo, oficinas, palestras e discussões em torno da agroecologia e do ativismo alimentar. Além desses eventos, houve a produção dos Sucos Específicos, que foram vendidos na lanchonete da Bienal. O artista considera "esse projeto como não só uma primeira síntese do que foi o pós-doc, mas também a base do que virou o Restauro mais adiante"196.

Esses interesses sobre a alimentação baseada em plantas surgiram no doutorado, diz o artista, primeiramente relacionados somente à sua biografia e à sua própria alimentação, e depois se conectando com conceitos e problemas que ele já trabalhava, como as questões "da terra, do território, de ocupação de espaço, de uso dos lugares, uso da terra", como se fosse a mesma conversa, a continuação do seu trabalho múltiplo, colaborativo e discursivo, porém agora compreendendo o alimento como "um dos mediadores principais da relação sociedade-ambiente"197. Um livro muito importante que ajudou o artista a fazer essas conexões foi Undermining ${ }^{198}$, de Lucy Lippard, que discute como o modo de viver do ser humano impacta o meio ambiente e transforma a paisagem. A partir de então, o artista imagina uma transformação da paisagem a partir do modo como cada um se alimenta.

Para lidar com esses novos questionamentos, JMB constrói uma imagem que relaciona o funcionamento do meio ambiente, que resulta em uma determinada visualidade da paisagem, com o funcionamento do sistema digestivo, a partir do tipo de alimento consumido. Hoje há uma baixa diversidade na alimentação humana, reduzida a cinco plantas - trigo, milho, feijão, cana-de-açúcar e soja -, enquanto existem em média 25 mil espécies de plantas que podem servir na alimentação, tal como nos alerta JMB. Uma

${ }^{196}$ Entrevista concedida por JMB, localizada no Anexo 3 desta tese.

197 Entrevista concedida por JMB, localizada no Anexo 3 desta tese.

${ }^{198}$ Lucy Lippard, Undermining, 2014. 
alimentação complexa e "limpa" vai resultar em um meio ambiente complexo e limpo. Daí que o artista lança o conceito de "escultura ambiental", para questionar se "o que comemos define a paisagem na qual vivemos?", e considerar os sistemas digestivos como "ferramentas escultóricas"199. Ou seja, o modo como nos alimentamos faz com que a imagem da paisagem seja transformada, uma decisão que vai ter impacto direto no desenho e na diversidade da paisagem. Como transportar essa imagem e funcionamento da pesquisa artística de JMB para um grande exposição do porte da Bienal de São Paulo? O artista diz que pensou em várias soluções e que criar um restaurante, se apropriando do espaço da própria Bienal, foi a estratégia expositiva que pensou para dar conta dessa pesquisa em curso:

Mais do que pensar em uma ideia de representação da floresta dentro do pavilhão, pensei que o alimento poderia dar conta dessa extensão. De pensar a Bienal como uma extensão da floresta e como parte de um sistema que tanto a agrofloresta alimenta a Bienal, como a Bienal, a partir de uma dimensão econômica, retroalimenta essas famílias que foram as fornecedoras. Então, a dimensão econômica se faz presente por uma necessidade de alimentar esse sistema. ${ }^{200}$

Este capítulo conclui com esta imagem forte que o artista cria, um sistema de setas que fazem o movimento de transformação do meio ambiente até a instituição e vice-versa, uma imaginação diagramática que está associada ao entendimento que JMB tem da arte, uma visão que também pode estar associada ao seu interesse em percorrer uma carreira acadêmica e artística. A arte, segundo JMB, tem uma dimensão reflexiva ou metabólica, tão importante quanto qualquer outro aspecto estrutural. É a "possibilidade de leitura, de deglutição, que se encontra na sala de aula, na universidade ou na biblioteca. 199 \#32bienal (Ativação de obra) Jorge Menna Barreto: Restauro, 2016, https://youtu.be/IXvj_ xoqs7U. 
São ambientes privilegiados para que você exerça esse momento metabólico"201, momento de reflexão e leitura dos outros artistas, dos outros autores, da produção artística, que se faz dos outros campos do conhecimento. Desse modo, JMB atualiza o conceito de "influxos reflexivos", criado em sua dissertação, para o entendimento da obra de arte através da "dimensão metabólica", atualização que se dá no desenrolar de sua pesquisa específica sobre alimentação. Nesse sentido, para o artista, a pesquisa na universidade é mais do que um "recuo crítico", é um "recuo digestivo" em relação ao tempo acelerado de produção de obras para exposições:

No momento em que você engole algo, já não está mais operando no campo da visibilidade, mas de uma outra temporalidade que demora horas e horas para você digerir, para você descompactar aquilo que come, que é um processo de desconstrução e de penetração em uma esfera molecular. Então, se você vir uma maçã e imaginar o que acontece com uma maçã dentro do seu organismo, ela é completamente desmembrada e aberta. Então, eu acho que o processo digestivo é um processo analítico ${ }^{202}$.

A conexão entre processos reflexivos e processos digestivos explica os desdobramentos recentes de seu projeto poético, que avança sobre o alimento, em uma pesquisa artística específica sobre os campos da ecologia e da agricultura, dentro e fora da universidade. Muitas obras de JMB são obra de pesquisa sobre a própria arte, tal como Projeto Matéria, um ensaio metodológico sobre o site-specificity, que constitui também um exercício metalinguístico sobre a aula de arte contemporânea, ampliado para questões sobre mediação e participação no contexto institucional da arte. Porém, entre 2012 e 2013, o artista começou a deslocar essa condição para mais adiante do campo da arte, transferindo o objeto de sua pesquisa para a agroecologia, a

${ }^{201}$ Entrevista concedida por JMB, localizada no Anexo 3 desta tese.

202 Entrevista concedida por JMB, localizada no Anexo 3 desta tese. 
agricultura familiar, a alimentação baseada em plantas, vegana ou vegetariana, orgânica e sobretudo da agrofloresta, estabelecendo uma relação visual e diagramática, artivista e colaborativa, entre o meio ambiente e a alimentação das pessoas. 
101 

CAPÍTULO 3

OS ESTADOS

DA PESQUISA ARTÍSTICA 



\section{Fenômeno da pesquisa do artista na universidade europeia}

A década de 2000 viu surgir um extenso debate sobre a relação da arte com a educação superior, com o aumento de cursos de doutorado em Arte e em torno do uso do termo pesquisa conectado à produção artística. Um pouco antes de JMB entrar no mestrado e criar Projeto Matéria, aconteceu em 2003 em Amsterdã a conferência "Artistic Research", a primeira a ocorrer na Europa dentro de uma nova onda de criação de programas de pós-graduação próprios para o artista, marcando o início de um fenômeno no contexto universitário europeu, expandido para outros circuitos artísticos e para outros países. A conferência teve a participação de pesquisadores e curadores como Mika Hannula, Gertrud Sandqvist e Sarat Maharaj e deu origem a um dos primeiros livros sobre o tema nessa nova perspectiva ${ }^{203}$. No prólogo do livro, os editores Annette Balkema e Henk Slager dizem que o ensino superior em Arte estava em desenvolvimento naquele período e que era urgente explorar o termo pesquisa para a produção artística ${ }^{204}$. Ocorre que em muitos países europeus ainda não existiam programas de pós-graduação próprios de pesquisa artística na universidade, nem em Artes Visuais, Música, Artes Cênicas, etc., com a defesa combinada tanto de produção artística quanto de reflexão na forma de texto dissertativo ou tese, e mesmo em países como Estados Unidos essa ainda é uma área pouco explorada ou em fase de estabelecimento ${ }^{205}$.

Esse rumor, por parte da arte, em torno da palavra-chave "pesquisa" é parte do processo de transformação, na Europa, das tradicionais academias de arte e de outros tipos de escolas superiores de arte em universidades ${ }^{206}$, no momento em que "conhecimento" e "pesquisa e desenvolvimento" tornam-se

203 James Elkins situa a coletânea, que foi lançada em 2004, como o primeiro livro deste fenômeno e diz que a bibliografia sobre o que ele chama de "studio-art PhD" disparou em vários países a partir de então, a ponto de uma pessoa apenas não dar conta de tantos livros ou ter a certeza de não estar repetindo ideias já propostas em outros lugares. James Elkins, Introduction, 2014, p. xiii.

204 Annette Balkema e Henk Slager, Prologue, 2004, p. 9.

205 Ver: James Elkins, List of PhD Programs Around the World, 2014, pp. 28-30.

${ }_{206}$ Tal como visto no Capítulo 1, no Brasil, esse processo de transformação das escolas e academias de arte estatais em institutos ou departamentos universitários foi ocorrendo ao longo do século 20 até a chegada da Reforma Universitária de 1968, em que todas as escolas foram encampadas em institutos universitários ou extintas. 
denominações estratégicas para os países, em termos econômicos e geopolíticos, em um cenário globalizado e de orientação neoliberal. Essa transformação ocorreu como consequência do acordo político chamado Declaração de Bolonha ${ }^{207}$, firmado em 1999 pela União Europeia, e que instituiu um processo de reformas universitárias para a revisão e padronização de todos os sistemas de ensino superior. O processo que se desenrolou a partir desse acordo objetivou, além da criação de um Espaço Europeu de Ensino Superior (EEES), que veio a ser instituído em 2010, a uniformização de titulações e currículos em todas as áreas, para que se pudesse estabelecer a comparação entre países, desenvolver critérios únicos de qualidade e metodologias, criar um sistema internacional de transferência de créditos para o intercâmbio entre universidades e instituir um sistema de três ciclos formado por graduação, mestrado e doutorado.

Henk Borgdorff fala em 2005 sobre a urgência e o crescimento dos debates, naquele período, em torno de questões ontológicas, epistemológicas, metodológicas e sobre estratégias e políticas educacionais de estabelecimento da pesquisa do artista na universidade. $\mathrm{O}$ autor sinaliza que nesse processo houve grandes debates sobre o que seria a pesquisa "em escolas de teatro e dança, conservatórios, academias de arte e outras escolas profissionais das artes", pontuando uma condição totalmente diferente que existia entre as escolas de arte europeias, anteriormente ao processo de Bolonha, e o mundo acadêmico da universidade e dos institutos de pesquisa ${ }^{208}$.

Tom Holert alerta para uma nova preocupação da arte sobre a pesquisa, agora institucionalizada como disciplina acadêmica, e que a escola de arte começa a ser pensada nos termos de uma combinação entre prática artística e prática científica, para além do ensino da arte somente, dentro dessa reflexão sobre a transformação ou encampamento das academias e escolas de arte europeias dentro do sistema universitário. Essa mudança, diz o autor, sugere "demandas e expectativas da comunidade científica e das agências de fomento

207 Para uma abordagem crítica da relação da arte com o conhecimento disparada pela pesquisa artística e o Processo de Bolonha, ver: Dieter Lesage, The Academy is Back, 2009; Franco Berardi, Cognitarian Subjectivation, 2010; Dieter Roelstraete, Critical Mess, 2010; Tom Holert, Artistic Research, 2011. 
em relação aos resultados" no mesmo nível de qualquer pesquisa feita na universidade ${ }^{209}$.

Para Slager, ainda que o processo tenha sido lento, empreendeu uma mudança significativa no modelo anterior, "introvertido, romântico, prédemocrático e não dialógico", baseado na relação "mestre-pupilo". O autor fala sobre um apagamento de limites entre Arte e Ciência, em direção a estudos críticos e de contexto, permitindo mais projetos experimentais, colaborativos e interdisciplinares, em conversa com outros campos artísticos, a arquitetura, o design, o cinema, expandindo-se também para relações entre Arte e Tecnologia ou para trocas com outros campos, a história, a filosofia, a biologia, por exemplo ${ }^{210}$.

Dieter Lesage atenta para a obrigação de as academias de arte, no tradicional sentido dessas escolas de arte no contexto europeu, como academias de belas artes"11, tornarem-se "acadêmicas", no momento em que elas se transformam em instituições universitárias: "Particularmente confuso para essas "academias" foi o fato de que muitas delas estiveram anteriormente empenhadas pedagogicamente em deixar claro que aprender e ensinar se dava da forma menos 'acadêmica' possível" ${ }^{212}$. Com isso, o autor faz uma brincadeira com o peso tradicional que a palavra "arte acadêmica" carrega, e pergunta se a novidade do meio acadêmico para o ambiente livre das escolas de arte europeia a tornariam mais protocolares, menos preocupadas com uma criação aberta, pois teriam que atentar para questões até então não próprias da criação artística. Ainda assim, a palavra academia, termo clássico utilizado tanto em Academia de Belas Artes quanto em Academia de Ciências, pode revelar-se nova a partir dos cruzamentos atuais entre a arte e outros campos do conhecimento.

A transformação das universidades europeias, para Borgdorff, não é o único motivo para todos os debates ao redor da pesquisa artística, considerando-se os próprios desenvolvimentos que vinham ocorrendo na arte

\footnotetext{
209 Tom Holert, Art in the Knowledge-based Polis, 2009. (Tradução do autor.)

${ }^{210}$ Henk Slager, Temporary Autonomous Research, 2015, pp. 7-8. (Tradução do autor.)

${ }^{211}$ Neste sentido, ver a história das Academias de Arte europeias, do Renascimento à Bauhaus, no livro publicado originalmente em 1940: Nikolaus Pevsner, Academias de arte, 2005.

212 Dieter Lesage, Who's Afraid of Artistic Research?, 2009. (Tradução do autor.)
} 
contemporânea, e mais, provenientes de uma longa tradição modernista, de questionamentos ampliados que atravessam todo o século 20 até hoje. Pode-se perceber, do cubismo analítico ao site-specificity, um fenômeno mais amplo de relações da arte com outros campos do conhecimento. $\mathrm{O}$ autor cita a pesquisa artística no caminho já trilhado nos anos 1990 em palavras-chave como “diversidade cultural", termo que pode estar ligado com questões políticas e de crítica institucional em uma arte oriunda de diversas regiões do mundo, e sobre os "new media", a arte tecnológica de interatividade e de pesquisa sobre a ciência. Dessa forma, pesquisa e reflexão já seriam algo presente em diversos circuitos artísticos, sendo que "pesquisa" não é mais "um tópico somente de universidades, empresas, agências de consultoria ou centros de pesquisa independentes; também os artistas e as instituições de arte estão cada vez mais chamando suas práticas de "pesquisa"”213.

No contexto dessas novas discussões sobre a situação das novas escolas universitárias de arte, surge um dos primeiros termos utilizados para definir a pesquisa do artista na universidade: “practice-based research", pesquisa baseada em prática. Isso ocorreu muito pelo que já vinha sendo realizado em países como Reino Unido, pois "practice-based research" era o termo desenvolvido lá, de forma pioneira entre o final dos anos 1970 e início dos anos $1980^{214}$, período em que no Brasil se estabelecia a pesquisa em arte ou as poéticas visuais, tal como visto anteriormente. No Japão, França, Austrália e Finlândia tais debates também começaram a acontecer pela primeira vez, de acordo com cada contexto, sobre o que deveria ser a pesquisa feita pelo artista na universidade, além de outras discussões em torno da institucionalização de bolsas de estudo e auxílios de pesquisa para a área e da criação de associações próprias desses artistas, bem como de novas metodologias. Borgdorff diz, em um texto de 2005, que naquele momento a pesquisa artística, espalhando-se para vários países europeus, já tinha sido vista de forma minuciosa em outros países, sendo o caso inglês o mais próximo e emblemático para eles: "Isso não

${ }^{213}$ Henk Borgdorff, The Debate on Research in the Arts, 2012, pp. 32-33. (Tradução do autor.) 
quer dizer que todas as respostas devam vir do exterior. No entanto, é sempre bom aprender com ideias e experiências que outros já tiveram” 215.

\section{Situação do doutorado em Arte em alguns países}

Alguns autores discorreram sobre os contextos que estão inseridos a respeito da pesquisa do artista na universidade, e seus relatos são valiosas peças para um esboço dessa empreitada. James Elkins elaborou uma lista de "programas de doutorado ao redor do mundo", o que ele chama de "studio-art $\mathrm{PhD}$ "216, que consta em um livro organizado por ele. A lista permanece aberta em seu site pessoal para novas inclusões e recebe a ajuda de quem quiser colaborar ${ }^{217}$. Segundo o autor, em texto de 2013, são muitas as universidades no mundo que oferecem doutorados para artistas. Ele se pergunta qual é a conversa em comum que acontece entre esses programas, se eles compartilham as mesmas preocupações, já que ninguém visitou todas as instituições para se ter um balanço. Elkins fala sobre as dificuldades geográficas, problemas com idiomas, legislação de cada país, e a falta de comunicação sobre o assunto, para que seja estabelecido um painel preciso ${ }^{218}$. A seguir é feita uma exposição sobre a situação da pesquisa artística universitária em alguns países ${ }^{219}$, a partir de sua manifestação mais evidente, que são os cursos de doutorado, com o intuito de constatar, primeiro, como ela é uma matéria muito nova e ainda em processo de construção; segundo, que o exemplo brasileiro é precursor em muitos aspectos, sobretudo naqueles relacionados com institucionalização, criação de grupos de pesquisa e interesse dos artistas; e, por último, que há uma coincidência no surgimento, pelo mundo, de alguns programas de pós-graduação próprios para o artista, entre o final dos anos 1960 e o começo dos anos 1970.

\footnotetext{
215 Henk Borgdorff, The Debate on Research in the Arts, 2012, pp. 36-37. (Tradução do autor.) 216 James Elkins, List of PhD Programs Around the World, 2014, pp. 17-32.

217 James Elkins, Artists with PhDs, http://www.jameselkins.com/yy.

218 James Elkins, Six Cultures of the PhD Around the World, 2014, pp. 3-16.

219 A respeito da pesquisa artística na universidade, onde a produção artística convive com a produção científica, foram selecionados alguns países em razão do pioneirismo, de sua recente implantação com aumento crescente dos debates ou da peculiar falta de interesse no desenvolvimento destes doutorados para artistas.
} 
No Reino Unido as escolas de arte e design começaram a ser integradas, a partir de 1966, às antigas instituições politécnicas britânicas, que existiram até 1992, quando estas começaram, por sua vez, a ser transformadas em universidades. A partir da década de 1970 os institutos politécnicos, juntamente com o Council for National Academic Awards (CNAA) ${ }^{220}$, a antiga autoridade de regulamentação de diplomas, começaram a conferir diplomas de mestrado (MPhil) e doutorado (PhD), sob uma regra que permitia que a defesa fosse composta de parte escrita, com 10 a 15 mil palavras para o mestrado, e com 20 a 30 mil palavras para o doutorado, como também de uma apresentação de obra de arte ou trabalho criativo, parte integrante da tese. Segundo Erik Borg, uma cultura de "practice-led" ou "practice-based PhDs" começou a acontecer, mas não sem passar por um processo complicado, com poucos trabalhos defendidos até 1995, por exemplo, com orientadores vindos de outras áreas, da História da Arte ou dos Estudos Culturais, e sem um consenso sobre uma metodologia para área de Artes Visuais, diferente do Design, que se adaptou melhor com desenvolvimentos provenientes das Ciências Sociais ${ }^{221}$. O primeiro doutorado em Artes Visuais desenvolvido nesse modelo começou em 1975 pelo artista Andrew Stonyer, que teve o apoio do CNAA, e foi defendido em 1978 , com o título de The Development of Kinetic Sculpture by the Utilisation of Solar Energy, contando com a produção de uma escultura cinética, em um coorientação de dois institutos, o Leicester Polytechnic, hoje Montfort University, e a Slade School of Fine Art, de Londres ${ }^{222}$. Victor Burgin conta que em 1973 havia entrado na Escola de Comunicação do Instituto Politécnico Central de Londres e que muitos artistas daquele período tinham rumado para os departamentos de Humanas para escrever as suas teses. "Hoje, esses alunos teriam a opção de cursar um doutorado no departamento de Artes Visuais”223. No começo dos anos 1990 a situação da pesquisa artística já estava bem

220 A CNAA foi um órgão criado em 1960 para a atribuição de títulos de ensino superior de cursos realizados em institutos de ensino não universitários, como os politécnicos.

${ }^{221}$ Erik Borg, The Experience of Writing a Practice-based Thesis in Fine Art and Design, 2009, pp. 45-6o.

${ }_{222}$ Erik Borg, The Experience of Writing a Practice-based Thesis in Fine Art and Design, 2009, p. 87. 
estabelecida no Reino Unido, muito tempo antes de outros países europeus, amplamente conduzido em várias escolas de arte e universidades, com um número grande de alunos, sendo o doutorado a titulação de entrada para a carreira acadêmica ${ }^{224}$. Os cursos de pós-graduação em Arte no Reino Unido, segundo Timothy Emlyn Jones, começaram a multiplicar-se somente a partir de meados dos anos 1980, excetuando algumas experiências pioneiras que ocorreram na Royal College of Art e na Slade School of Fine Art ${ }^{225}$. Além destes, há outros exemplos de universidades inglesas com doutorados para artistas, com programas de pesquisa teórica e prática, como a Universidade de Artes de Londres, a Goldsmiths, Universidade de Londres, que também oferece outro doutorado em Arte e Tecnologia, o doutorado em Práticas Artísticas da Universidade de Brighton, e o doutorado em Artes Visuais, Design e Arquitetura da Escola de Arte de Glasgow. Outro exemplo conhecido é o Planetary Collegium da Universidade de Plymouth, estabelecido pelo artista e teórico da arte tecnológica Roy Ascott, primeiramente em 1994 com o nome de Centro de Investigação Avançada em Artes Interativas (CAiiA), na Universidade do País de Gales, no Reino Unido. É interessante notar na fala de Sarat Maharaj, feita na conferência “Artistic Research", citada anteriormente, que para alguém que vem da Inglaterra nem a área, nem essas discussões são novas, já que há uma tradição de pesquisa artística há muito tempo estabelecida por lá226. Por isso o processo de Bolonha não foi revolucionário para as escolas de arte britânicas nem as impactou como ocorreu no restante dos países europeus.

No Japão, a Universidade das Artes de Tóquio, conhecida como Geidai, estabeleceu seus programas de doutorado em 1977, e as primeiras defesas fora realizadas em 1982. A escola conta hoje com três programas: Artes Visuais, Música, e Cinema e Novos Meios. O modelo desenvolvido por lá serviu de referência para outras universidades japonesas, exigindo a defesa de uma parte escrita em conjunto com a produção artística, o que requer habilidades tanto artísticas quanto de pesquisa acadêmica. O fato é notado com surpresa por James Elkins, que lista vinte universidades que empreenderam esse tipo de pós-

224 James Elkins, Seven Questions on Arts as Research, 2011, p. 88.

225 Timothy Emlyn Jones, The PhD in Studio Art Revisited, 2014, p. 107.

${ }^{226}$ Annette Balkema et al., Discussion, 2004, p. 167. 
graduação nas mais diversas áreas artísticas. O autor, que não menciona o caso brasileiro da ECA-USP, diz que o Japão e o Reino Unido são cofundadores do que ele chama "studio-art PhD”, em termos de duração, tradição, independência e número de alunos, e que poucos estudiosos europeus e norte-americanos, hoje às voltas com uma área para eles nova, têm consciência disso ${ }^{227}$.

Na França, até 1968 o ensino da arte estava restrito às academias de arte. Diferente do que aconteceu em outros países, essas academias não foram transformadas até hoje, em sua maioria, em institutos universitários. Ocorre que departamentos de Artes começaram a ser criados nas universidades, a partir da reforma universitária que se seguiu às manifestações estudantis de 1968, em um processo de reorganização, desmembramento ou criação de novas universidades, de adoção de um sistema de créditos e do incentivo à interdisciplinaridade, entre outras mudanças. Um desses primeiros cursos estabelecidos foi o da Université Paris 1 Panthéon-Sorbonne, dentro da Escola de Artes da Sorbonne, que teve como uma de suas professoras a artista Lygia Clark. O curso surgiu como um desdobramento do Instituto de Estética e Ciências da Arte (IESA) - fundado por Étienne Souriau em 1960 e levado adiante depois por René Passeron ${ }^{228}$ nos anos 1970. Bernard Teyssèdre criou um doutorado no final dos anos 1970, que procurava unir teoria e produção da arte, chamado "Artes e Ciências da Arte", na especialidade chamada "Artes Plásticas”. Todos esses esforços foram precursores da pesquisa artística levada adiante por essa universidade, hoje oferecida pelo programa de doutorado em Artes Plásticas, Estética e Ciências da Arte (APESA) e do grupo de pesquisas do Instituto ACTE (Pesquisas em Artes, Criações, Teorias e Estética) surgido em 2012229. Segundo Bernard Darras, "na França, dois sistemas coexistem: a

227 James Elkins, Introduction, 2014, p. xiii.

${ }_{228}$ No trecho a seguir, presente em um texto de René Passeron, pode-se perceber os significados da pesquisa poética: "Aliás, a poética se ocupa menos dos afetos do artista do que dos lineamentos dinâmicos, voluntários e involuntários que o ligam à obra em execução. Em suma, seu objeto é a poiesis que põe o criador frente a seu projeto e não a aistesis que ele pode experimentar em sua ação ou suscitar através dela. E foi então que os membros do grupo que eram não somente doutores ou doutorandos, mas também artistas, como os músicos Bosseur e Tamba, o pintor R. Conte, o ator e diretor Chabert, especialista em Beckett, etc. foram levados a dar uma definição precisa da palavra criação". René Passeron, Da estética à poiética, 1997, p. 108. 
universidade, que é a herdeira da formação dos professores em educação artística, e as escolas de artes, que são herdeiras do sistema das Belas-Artes" ${ }^{230}$. Por muito tempo somente as universidades podiam ter programas de mestrado e doutorado. Após os mudanças propiciadas pelo Processo de Bolonha, as escolas de arte começaram a ter também esse privilégio, abrindo polos de pesquisa em parceria com as universidades. A Les Beaux-Arts de Paris, ou Escola Nacional de Belas Artes de Paris (ENSBA), é uma das instituições que formam o programa de doutorado chamado Ciência, Artes, Criação, Pesquisa (SACRe) desenvolvido pela universidade de pesquisa Paris Sciences et Lettres (PSL), com a Escola Normal Superior (ENS), a Escola Nacional de Artes Decorativas (ENSAD), a Escola Nacional de Imagem e Som (Fémis), o Conservatório Nacional Superior da Música e Dança de Paris (CNSMDP) e o Conservatório Superior Nacional de Arte Dramática (CNSAD). Criado em 2012, ele abraça projetos nas áreas de Artes Visuais, História da Arte, Dança, Teatro, Cinema, Música e Design, é o primeiro doutorado francês definido, nos termos recentes, como de pesquisa artística.

Elkins diz que na Austrália o número de diplomados de doutorado é muito alto, por volta de 500, entre 2003 e $2013^{231}$. Seguindo reformas do setor universitário no país, ocorridas a partir de 1987, várias escolas e institutos de arte foram inseridos institucionalmente nas universidades, o que levou a uma aproximação da arte com a pesquisa e ao consequente acesso aos fluxos de financiamento. Os assim chamados "doutorados em Artes Criativas" começaram a ser oferecidos em 1984 pela Universidade de Wollongong, nas áreas de Artes Visuais, Design Gráfico, Música, Performance, Artes Cênicas, Escrita Criativa e Jornalismo, com os esforços do compositor britânico Edward Cowie, então chefe da Escola de Artes. ${ }^{232}$

Na Finlândia, a Escola de Arte, Design e Arquitetura da Universidade de Aalto, que surgiu como Escola de Artesanato em 1871, concedeu seus primeiros DA (Doctor of Arts) em 1991, embora o programa tenha sido implementado

\footnotetext{
230 Bernard Darras, Pesquisa em arte por ocasião dos doutorados baseados na prática, 2012, pp. 111-112.

${ }_{231}$ James Elkins, List of PhD Programs Around the World, 2014, pp. 26-27.

${ }^{232} \mathrm{Su}$ Baker et al., CreativeArtsPhD, 2009, p. 27.
} 
desde o começo da década de 1980. Na Academia Finlandesa de Belas Artes, hoje parte da Universidade de Artes de Helsinque, o primeiro doutor formou-se em 2001, apresentando prática artística e parte teórica escrita. Annette Arlander diz que a Finlândia foi um dos primeiros países europeus a se engajar com a pesquisa artística. Uma das razões para que esse envolvimento tenha ocorrido, sendo ela, é que as escolas de artes na Finlândia já estão integradas ao sistema universitário há mais tempo233.

Um doutorado em Estudos e Práticas Artísticas existe desde 1997 na Universidade de Quebec em Montreal (UQAM). Reúne Dança, Teatro, Música, Artes Visuais e Midiáticas, Design e História da Arte e oferece três caminhos possíveis: tese-pesquisa; tese-intervenção e tese-criação, este último mais próximo dos significados de um pesquisa artística na universidade, segundo relatam Sylvie Fortin e Pierre Gosselin, responsáveis por estabelecer o doutorado nessa instituição ${ }^{234}$. Segundo Elkins, o Canadá tem quatro universidades com pesquisa artística. Além da Universidade de Quebec, ela acontece na Universidade Concórdia de Montreal, com três cursos de doutorado de "criação-pesquisa" atrelado ao departamento de Comunicações; no departamento de Artes Visuais da Universidade de Western em Ontário desde 2007; e na Universidade Ryerson de Toronto , iniciado em 2006.

Em Portugal, segundo a pesquisadora Catarina Almeida, os cursos de doutorado, como na maioria dos outros países europeus, foram desenvolvidos recentemente na sequência do Processo de Bolonha, que reorganizou o ensino em três níveis, de modo que somente universidades reconhecidas por sua pesquisa podem ser responsáveis em conceder títulos de doutor, que legalmente tiveram apoio, de fato, somente a partir de 2009235. A Universidade de Lisboa, por exemplo, tem dois doutorados próprios à criação do artista: o doutoramento em Belas Artes e o doutoramento em Artes Performativas e da Imagem em Movimento, este último em colaboração com o Instituto Politécnico de Lisboa.

233 Annette Arlander, Artistic Research in a Nordic Context, 2013, p. 152.

234 Sylvie Fortin e Pierre Gosselin, Considerações metodológicas para a pesquisa em arte no meio acadêmico, 2014. 
Na Holanda, como algumas academias de arte ainda não têm o status de universidade, há uma cooperação entre elas e os institutos presentes em universidades para a criação de programas ${ }^{236}$. PhDArts é um programa de Artes Visuais e Design desenvolvido em conjunto pela Academia Real de Arte de Haia e Academia de Artes Criativas e Artes Cênicas da Universidade de Leiden. Outro programa, o docArtes, implementado em 2002 por Henk Borgdorff, é de pesquisas baseadas em música, apoiado por diversas instituições, pelo Instituto Orpheus de Gante e pela Universidade Católica de Leuven, na Bélgica, pelos conservatórios de Haia e de Amsterdã e pela Universidade de Leiden, na Holanda ${ }^{237}$. A Academia Gerrit Rietveld, em parceria com a Universidade de Amsterdã, confere títulos de doutorado em pesquisa artística desde 2016. Uma outra iniciativa, inaugurada pela academia em 2017, é a criação de um programa e título de doutorado chamado Creator Doctus (CrD), em parceria com o Van Abbemuseum, de Eindhoven. A primeira artista a fazer parte desse programa é Yael Davids, para o período 2017-2019, com o objetivo de criar uma série de obras, e sendo que uma delas foi apresentada na documenta 14, em 2017. O programa pioneiro, que prescinde da parte escrita, para ser reconhecido é desenvolvido em colaboração com universidades. Na Escola de Artes da Universidade de Utrecht (HKU) há somente programas de mestrado como os de Artes Visuais, Cenografia e Música. Slager, uma das pessoas que mais se envolveu com o fenômeno recente da pesquisa artística no contexto europeu, promovendo várias exposições e simpósios, é professor decano nessa escola.

$\mathrm{Na}$ Áustria, seis grandes academias e escolas superiores de arte (Kunsthochschulen) foram transformadas por lei em universidades independentes a partir de 1998. A partir de 2002 elas obtiveram o mesmo status científico e de pesquisa das outras universidades, reconhecimento que também abre as portas para bolsas de estudos e auxílios para projetos propostos por essas instituições. A Universidade de Arte e Design de Linz, fundada como Kunstschule em 1947, a Universidade de Artes de Graz (KUG), criada originalmente como Akademischer Musikverein em 1816, e a tradicional

${ }^{236}$ Ver mais sobre a pesquisa artística na Europa, e sobretudo na Holanda, em: Catarina Almeida, After Artistic Research, 2015.

${ }_{237}$ Henk Borgdorff, Artistic Research and Academia, 2012, p. 62. 
Academia das Belas Artes de Viena, que existe desde 1692, começaram a construir seus programas de mestrado e doutorado a partir de então. Por outro lado, elas não podem atribuir, por lei, títulos artísticos, somente científicos, ou seja, a obra de arte ainda não é considerada na defesa das dissertações e teses $^{238}$.

O primeiro financiamento para pesquisa artística na Suécia aconteceu em 1978, logo após reformas em seu sistema de ensino superior, porém o reconhecimento da Arte como uma área designada a receber auxílio pelo órgão de financiamento do país ocorreu somente em 2000, com esforços da comunidade de artistas-pesquisadores. Antes disso, segundo a coreógrafa Efva Lilja, os artistas dependiam da cooperação da comunidade científica para obter recursos, em projetos interdisciplinares, no geral como "pesquisadores de apoio". ${ }^{239} \mathrm{O}$ estabelecimento de um doutorado para artistas surgiu em 2002 na Academia de Arte de Malmö, parte da Universidade de Lund, segundo Sarat Maharaj ${ }^{240}$, professor nesse programa. A partir disso, programas de doutorado de prática artística começaram a ser desenvolvidos na Universidade de Gotemburgo, dentro de suas academias: a Valand, a de Design e Artesanato (HDK), e a de Música e Artes Cênicas. A Academia Valand, de Artes Visuais, fundada em 1865, faz parte da universidade desde 2007 e agregou em 2012 os departamento de Cinema, Fotografia e Composição Literária.

Na Suíça algumas faculdades de arte foram criadas a partir da união de outras escolas de arte, que já vinham de uma tradição e de uma história no país, todas também passando pelo processo novo de inserção da pesquisa em suas atividades. Em 2003, a Faculdade de Artes de Berna foi criada a partir da fusão da Faculdade de Música e Teatro com a Faculdade de Design, Artes e Conservação. Desde 2011 oferece curso de doutorado na Escola de PósGraduação em Artes (GSA), em cooperação com a Faculdade de Ciências Humanas da Universidade de Berna, e mestrado como curso preparatório para a entrada no doutorado. A Escola Superior de Arte e Design de Genebra (HEAD), criada em 2006 a partir da fusão entre a Escola Superior de Belas Artes de

${ }_{238}$ Torsten Kälvemark, University Politics and Practice-based Research, 2010, p. 6.

239 Efva Lilja, The Development of Artistic Research in Sweden 200O-2012, 2013. 
Genebra (ESAV) e a Escola Superior de Artes Aplicadas (HEAA), oferece atualmente cursos de mestrado e doutorado. A Faculdade de Artes de Zurique (ZHdK) foi criada em 2007, com a reunião da Faculdade de Arte e Design (HGKZ) e da Faculdade de Música e Teatro (HMT). Segundo Kälvemark241, a razão para essas fusões foi o desejo de fortalecer essas instituições para que começassem a receber atividades de pesquisa. A pesquisa feita pelo artista na Suíça é recente e está em desenvolvimento. Suas faculdades de artes ainda não podem conceder diplomas, e precisam sempre de parcerias com outras universidades ${ }^{242}$.

Nos Estados Unidos, os doutorados de estúdio foram desenvolvidos na Universidade de Nova York (NYU), segundo Timothy Emlyn Jones, antes mesmo da iniciativa pioneira britânica, porém foi abandonado depois que, em 1977, a Associação das Faculdades de Arte (CAA) estipulou o mestrado como o título máximo em Arte a ser obtido, o título para que professores deem aulas em escolas superiores de arte. $\mathrm{O}$ autor diz que essa posição está em discussão nos últimos anos, pois se percebe que há um interesse crescente na pesquisa artística, principalmente em decorrência do surgimento, em outros países, de uma geração de doutores em Arte243. James Elkins diz que os Estados Unidos não têm consistência histórica em doutorados artísticos, e que são poucas as universidades 244 no momento que concedem o título de $\mathrm{PhD}$ para artistas, sendo o único entre os países de língua inglesa que não têm o doutorado em Arte estabelecido ou em desenvolvimento. Segundo o autor, os doutorados em arte ainda enfrentam resistência de alguns artistas e acadêmicos, mas diz que os MA ou MFA já não são mais suficientes para a trajetória do artista ${ }^{245}$. Em vista dessa escassez, Emlyn Jones lança algumas sugestões sobre como o doutorado em Arte poderia ser desenvolvido nos Estados Unidos. Ele poderia espelhar-se

241 Torsten Kälvemark, University Politics and Practice-based Research, 2010, p. 7.

242 Jean-Pierre Greff et al. Les défis de la recherche en art et en design en Suisse, 2015, p. 84.

243 Timothy Emlyn Jones, The PhD in Studio Art Revisited, 2014, pp. 107-108.

244 Em texto de 2013, Elkins cita como exemplos de doutorado em Arte americanos o da Rensselaer Polytechnic em Artes Eletrônicas, o programa Arte e História da Mídia da Universidade da Califórnia, San Diego tem uma concentração chamada Prática da Arte, e o programa de doutorado em artes da Universidade de Tecnologia do Texas (TTU), na cidade de Lubbock, entre outros. James Elkins, List of PhD Programs Around the World, 2014, pp. 28-30. 245 James Elkins, Introduction, 2014, pp. xi-xii. 
no sistema já estabelecido no Reino Unido ou olhar para a tradição americana da arte que sempre esteve próxima da pesquisa artística, mas não institucionalizada na universidade. $\mathrm{O}$ autor diz que a pesquisa artística já tem uma forte predominância na cultura americana, só não está institucionalizada dentro de um programa próprio de doutorado para o artista ${ }^{246}$. Embora seja de um título do tipo STEM, focado em Ciência, Tecnologia, Engenharia e Matemática, deve ser citado aqui o Programa de Ciências e Artes da Mídia (MAS), que está atrelado ao Media Lab - laboratório fundando em 1985 por Nicholas Negroponte -, que oferece títulos de mestre e doutor, ambos parte da Escola de Arquitetura do Instituto de Tecnologia de Massachusetts (MIT). Além do Media Lab, faz parte dessa escola o Programa de Arte, Cultura e Tecnologia (ACT), que oferece um curso de mestrado em arte. Foi criado em 2009 da junção do Programa de Artes Visuais (VAP) e do pioneiro Centro de Estudos Visuais Avançados (CAVS)247, fundado em 1967 pelo artista György Kepes.

Em certos países como a Alemanha, influenciados por uma tradição filosófica analítica, a discussão sobre a pesquisa artística na universidade, com um acento na produção, aconteceu com menos força, diz Torsten Kälvemark ${ }^{248}$. Segundo o autor, houve resistência às mudanças propostas pelo Acordo de Bolonha em várias escolas de arte alemãs, oposição que levou alguns governos regionais a isentar essas escolas de adoção do novo padrão, mais próximo do funcionamento de uma universidade, incluindo aí a pesquisa. Porém o aumento do debate sobre a pesquisa artística em outros países diminuiu essa resistência ${ }^{249}$. Tom Holert, em texto de 2011, diz como as hostilidades e

246 A esse respeito, ele cita os exemplos da New Bauhaus, fundada por László Moholy-Nagy em 1937, hoje Instituto de Design (ID), parte do Instituto de Tecnologia de Illinois, em Chicago; a Black Mountain College, que funcionou de 1933 a 1957, abrigando artistas e pesquisadores como Buckminster Fuller, Josef Albers e Anni Albers, John Cage, entre outros; além de sua tradição pedagógica baseada na experiência e na experimentação, proposta por filósofos e pedagogos como John Dewey, David Kolb e Donald Schön. Timothy Emlyn Jones, The Studio Art Doctorate in America, 2014, pp. 172-173.

247 O CAVS do MIT foi um centro de pesquisas em arte e tecnologia, em colaboração com cientistas e engenheiros, em estudos emergentes à época como laser, vídeo, holografia, computação gráfica etc. Fizeram parte do centro ou passaram por lá artistas e pesquisadores como Otto Piene, Krzysztof Wodiczko, Vassilakis Takis, Jack Burnham, Douglas Davis, Antoni Muntadas etc. Ver: Matthew Wisnioski e Virginia Tech. Why MIT Institutionalized the AvantGarde, 2013, pp. 85-116.

248 Torsten Kälvemark, University Politics and Practice-based Research, 2010, p. 6. 
indecisões sobre a pesquisa artística passaram a ser menores nos países de língua germânica, dado o número de eventos que ele observou naquele ano, realizados em Viena, Berna, Zurique, Berlim, Weimar etc. ${ }^{250}$ A Universidade de Artes de Berlim (UdK) recebeu o grau de universidade em 1975, abarcando as áreas das artes visuais, do design, da música e das artes cênicas, podendo oferecer desde então cursos de mestrado e doutorado, e grupos de pesquisa. Porém o site dessa escola alerta para o fato de que "doutorados baseados na prática" não são oferecidos de forma explícita. Em 2016, a instituição abriu o Centro de Estudos Avançados em Artes e Ciências (BAS) como uma forma de aproximação do fenômeno e das discussões em torno da pesquisa artística na universidade, sendo este o núcleo que integra todos os programas de pósgraduação e as ações de pesquisa desta universidade. No entanto, há outras universidades onde pesquisa e produção artística vem sendo estimulada nos últimos anos, como o programa de doutorado da Academia de Artes da Mídia de Colônia, iniciado em 2004, com a ressalva de que a avaliação da tese ainda permanece nos termos científicos; o Dr. phil. in art. da Escola Superior de Artes de Hamburgo (HfbK), orientado à transdisciplinaridade, em uma relação científica com a arte; o programa de doutorado em Artes Visuais, Design e Artes da Mídia da Universidade Bauhaus de Weimar, onde defesas de tese podem consistir igualmente em parte científica e parte artística ou criativa. Na introdução do livro The Exposition of Artistic Research, de 2014, Michael Schwab e Henk Borgdorf dizem que nos países onde a pesquisa artística não está integrada ao sistema universitário ainda há a necessidade de validar e convencer a academia sobre a relevância da pesquisa efetuada pelos artistas, sobretudo aquela de prática ou produção artística. Os autores dizem que a Fundação de Pesquisa Alemã (DFG) foi chamada a apoiar a pesquisa artística, mas dizem que até aquele momento ainda havia resistência, pelos desafios de adequação aos parâmetros da pesquisa científica. Schwab e Borgdorf também discorrem sobre os problemas enfrentados em outros países sobre o processo de validade acadêmica, alertando para o modo instrumental ou de adequação às necessidades de "bem-estar social" e "crescimento econômico", sendo que a 
escrita da tese ou dissertação ainda permanece com um dos grandes problemas enfrentados entre artistas e orientadores, mesmo em países onde a pesquisa artística possui mais história, como Reino Unido, Austrália ou Finlândia²51.

Um panorama histórico mais preciso e abrangente sobre como a pesquisa artística aconteceu em variados países, ou mesmo no Brasil, exigiria uma investigação voltada somente para essa questão. São poucos os trabalhos acadêmicos hoje, realizados nacional ou internacionalmente, que buscaram compreender esses momentos históricos e ajudar a determinar as datas em que as primeiras teses de artistas foram defendidas ou as datas de início de programas voltados para artistas, ou ainda os tipos de defesa, se realizada somente com texto ou também com obras de arte. Deve-se atentar também que essa tarefa complexa ainda não foi realizada no Brasil, de modo que se estudem as peculiaridades de cada região, universidade ou de que se faça um levantamento dos artistas que pesquisam, nos muitos casos espalhados pelo país.

Programas, nomenclaturas e regras são criados ou descontinuados, dependendo das mudanças de legislação do ensino superior de cada país ou universidade. Deve-se também levar em conta que a definição de pesquisa artística é objeto de muitas discordâncias, com variados significados e caracterizações, o que impossibilita um desfecho único para essa história e só reflete a multiplicidade de procedimentos e interpretações que recaem no que pode ser entendido tanto como pesquisa quanto arte.

\section{Multiplicidade da pesquisa artística}

Pesquisa artística, do modo como se quer definida aqui e como expressão a ser adotada ao longo desta tese, assume os significados da pesquisa em arte ${ }^{252}$,

${ }^{251}$ Michael Schwab e Henk Borgdorf, Introduction, 2014, pp. 11-12.

${ }^{252}$ Ainda que haja, nesta tese, uma preferência terminológica irrestrita pela expressão pesquisa artística, não há problema algum na utilização de pesquisa em arte, expressão histórica amplamente aceita no contexto brasileiro para a pesquisa artística que é institucionalizada na universidade como área do conhecimento, que se torna uma disciplina acadêmica, ganha um programa de pós-graduação próprio, recebe auxílios e bolsas de agências de fomento e está organizada em uma associação coerente que congrega artistas-pesquisadores. 
porém se direciona a uma acepção mais aberta, em diálogo com o contexto internacional, contemplando diferentes instituições e circuitos artísticos, evidenciando, acima de tudo, o projeto poético do artista que se relaciona com o pensamento, o conhecimento, a pesquisa, a teoria, as ciências, a filosofia, os outros campos, os outros saberes.

Institucionalizado na universidade, esse tipo de pesquisa vem ocorrendo de forma pioneira aproximadamente desde a década de 1970, em lugares como Brasil, Reino Unido, Japão e Austrália. Recentemente essa pesquisa começou a ser desenvolvida em outros países, sendo motivo de vários debates, disparados pela transformação das escolas de arte em universidade no contexto europeu, com desdobramentos por outros lugares e ainda com repercussões em outros circuitos artísticos e na obra de artistas. É possível afirmar que a "pesquisa artística”, em um primeiro momento, pode ser entendida a partir de três constatações elementares que ajudam a defini-la em termos de institucionalização e de integração da arte no meio universitário: 1) a pesquisa do artista é feita na universidade; 2) um lugar próprio para a criação do artista é criado dentro da universidade em programas específicos de pós-graduação de pesquisa artística; 3) os resultados das pesquisas, dissertações ou teses constituem apenas obra de arte, ou se atrelam à obra um texto escrito, relatório de pesquisa, dissertação ou tese.

Ao mesmo tempo que são esboçadas essas constatações, podem ser feitos, a esse respeito, outros questionamentos sobre essas particularidades, de modo a ampliar o entendimento sobre o assunto: 1) a pesquisa artística é feita na universidade, porém, o artista também faz pesquisa em outros contextos de forma independente, ou ainda, mantém uma posição dentro da universidade e, ao mesmo tempo, atua em outros circuitos artísticos; 2) o fato de o artista ter um lugar próprio dentro da universidade, como um departamento ou um programa de pós-graduação, não o impede de, também na universidade, cursar mestrado ou doutorado em outros cursos, como história da arte, educação, filosofia, sociologia, engenharia etc.; 3) a pesquisa do artista pode ser composta de relatório, artigo, dissertação ou tese e ainda da produção artística, porém o artista pode desenvolver na universidade apenas produção textual e discursiva 
como, por exemplo, textos e teorias de artista, ou oficinas e encontros, sem se relacionarem, necessariamente, com o que usualmente é entendido como produção artística.

Sobre a pluralidade de tipos de pesquisa do artista na universidade, especificamente sobre uma parte desta realidade, que são os modos de defesa da tese ou dissertação, foi preparado um relatório em 2011 pelo Conselho Suíço de Ciência e Tecnologia (SSTC). O relatório trata da situação da "pesquisa e desenvolvimento" (P\&D) no campo das artes e foi elaborado em um momento de estabelecimento da pesquisa artística naquele país. Foi realizado um estudo comparativo de 31 programas de pós-graduação estrangeiros, que oferecem 41 titulações, de 23 universidades ou escolas de arte, tais como a Academia de Belas Artes de Viena, a Universidade de Leiden, a Academia de Arte e Mídia de Colônia, a Universidade Paris 1 Panthéon-Sorbonne, a Universidade de Artes de Londres, entre outras ${ }^{253}$. Além de vários nomes e siglas atribuídos a essas titulações 254 , há várias maneiras como os programas de pós-graduação em Arte organizam suas exigências de defesa e apresentação dos resultados da pesquisa do artista. O relatório verificou seis tipos de pesquisa e apresentação entre as 41 titulações de mestrado e doutorado estudadas, discriminados em relação ao modo de defesa e à predominância atribuída ao texto ou à produção artística: 1) existe apenas uma titulação em que a defesa é constituída apenas de apresentação pública de trabalho artístico, sem nenhuma apresentação de parte escrita relacionada às atividades de pesquisa; 2) existem dez titulações em que o peso maior é atribuído à parte artística e à sua apresentação, que é acompanhada de documentação ou reflexão escrita relacionadas com o desenvolvimento da produção; 3) há cinco titulações que dão importância menor ao projeto artístico, em relação à documentação ou à reflexão escrita; 4)

253 Marc-Antoine Camp e Blanka Šiška, Research Funding in the Arts, 2011, pp. 36-37 e 85-87. 254 Fora do Brasil, mestrados e doutorados são denominados por meio de várias nomenclaturas e siglas, dependendo da área. No caso do doutorado, o termo mais utilizado é o philosophiae doctor (do latim), cuja sigla é PhD. Muitos programas e universidades europeias, no entanto, utilizam outros termos e siglas, como, por exemplo, docteur, na França, dr. phil. e PhD na prática na Academia de Belas Artes de Viena, dr. phil. em Arte na Faculdade de Belas Artes de Hamburgo, dr. artium na Universidade de Artes de Graz, doutor em Artes na Universidade de Aalto University. Ver: Marc-Antoine Camp e Blanka Šiška, Research Funding in the Arts, 2011, p. 32 . 
em dez titulações é atribuído peso igual tanto aos componentes artísticos quanto aos acadêmicos; 5) existe uma titulação em que é permitido anexar documentação de projeto artístico à tese, ou seja, a produção artística não é o foco; 6) e, por último, a categoria com maior expressão: são catorze titulações em que não são aceitas a defesa de produções artísticas, somente de textos escritos como dissertações e teses 255 .

No Brasil, a denominação pode ser pesquisa artística, pesquisa em arte, poéticas visuais (contemporâneas, interdisciplinares, tecnológicas) ou ainda processos artísticos ou de criação. De modo geral, practice-led ou practicebased research no Reino Unido, künstlerische Forschung na Alemanha, recherche-création no Canadá. Também são adotadas expressões como arte como pesquisa, arte baseada em pesquisa, pesquisa criativa, pesquisa através da arte, pesquisa para a arte, dependendo do esquema classificatório realizado por cada autor. Clive Cazeaux diz que todas as expressões têm em comum a palavra "pesquisa", algo geralmente associado às universidades e aos laboratórios, e que o crescimento do vocabulário é sinal de que há um aumento crescente de interesse na área, embora também sejam reveladas incertezas e ansiedades, sobretudo na dificuldade de saber se a arte pode ser pesquisa ou pode criar pesquisa. ${ }^{256} \mathrm{O}$ autor prefere a expressão "pesquisa artística" porque faz uma relação com "pesquisa científica" e também porque é utilizada na literatura recente, principalmente por nomes como Henk Slager, Michael Schwab e Henk Borgdorff. Janneke Wesseling, diretora do PHDArts, prefere dizer pesquisa em arte, assim como também coloca Silvio Zamboni. Para ela, a expressão "pesquisa baseada na prática" está muito próxima da técnica e da tecnologia, e "pesquisa artística" acaba sendo uma expressão muito superficial e insatisfatória por se aproximar de qualquer pesquisa artística e não uma de área qualificada de pesquisa na área de Artes, em uma situação específica do artista na universidade 257 .

A abertura, a multiplicidade e o hibridismo da pesquisa artística são explícitos, já que ela é caracterizada em muitas denominações e entendimentos,

255 Marc-Antoine Camp e Blanka Šiška, Research Funding in the Arts, 2011, pp. 32-37.

${ }^{256}$ Clive Cazeaux, Art, Research, Philosophy, 2017, posição 263 (e-book).

257 Catarina Almeida, After Artistic Research, 2015, p. 165. 
fato que só faz comprovar uma condição semelhante que é própria da arte e mais ainda da arte de agora. Cada autor, artista ou instituição vai caracterizá-la, abordá-la e colocá-la em prática de uma maneira específica, dependendo do contexto, das regras do país, da maneira de se pensar, do propósito artístico etc. Não é possível estabelecer uma metodologia única, rigorosa e clara, para a pesquisa artística, segundo Slager, e isso torna infrutífero o repetido questionamento ontológico a respeito do que ela é. Daí que, ao contrário de outros tipos de pesquisa, somente ao final de cada projeto é possível determinar quais são as novas ideias metodológicas surgidas. ${ }^{258}$ Uma primeira incerteza surge a partir da pluralidade de tipos de artista e práticas artísticas relacionadas a termos como pesquisa artística, pesquisa baseada na prática, pesquisa em arte, que podem se referir às Artes Visuais, mas são denominações encontradas também em outras áreas artísticas, como o Design, a Música, as Artes Cênicas etc., e estão relacionadas com pesquisas empreendidas, por exemplo, em torno de um novo app, uma coreografia de dança, uma composição musical, o figurino de uma ópera, um método teatral, assim como também com a obra de arte, que pode ser tecnológica, matérica, educativa, discursiva, de crítica institucional, ambiental etc.; relacionar-se com outros campos do conhecimento como a História, a Etnografia e a Antropologia, por exemplo; ser, além disso, uma produção de desenho, pintura, gravura ou escultura; ou, ainda, não ter relação alguma com categorias fixas.

Faz-se urgente esclarecer a confusão em torno dos diversos nomes e significados da pesquisa artística, fenômeno novo e questão antiga, prática acadêmica e prática artística, arte que é feita na universidade por artistas que atuam como pesquisadores e professores, integrados ao sistema de ensino superior - que também podem circular por outros circuitos e instituições artísticas -, e também arte feita por artistas que não são necessariamente acadêmicos, mas que têm em seus projetos poéticos linhas muito próximas dos significados da pesquisa e da teoria, da ciência, da filosofia e de outros campos do conhecimento. Vários pesquisadores e teóricos tentaram definir os significados da pesquisa artística, sendo motivo de vários debates, livros, 
conferências e exposições nos últimos anos, fenômeno e linha poética que refletem sobre as instituições da arte e também sobre a obra de arte feita agora. A seguir, são citados alguns autores que ajudaram a identificar e caracterizar a pesquisa feita pelo artista, dentro ou fora da universidade.

Muito importante é o modo como a artista Sandra Rey, professora no Programa de Pós-graduação em Artes Visuais da UFRGS, destaca a pesquisa feita pelo artista das outras pesquisas da área de Artes Visuais. A autora diferencia a "pesquisa em arte" da "pesquisa sobre arte" em um texto publicado em 1996 chamado "Da prática à teoria: três instâncias metodológicas sobre a pesquisa em artes visuais". A pesquisa em arte segue a linha proposta por Silvio Zamboni, ou seja, é a pesquisa feita pelo artista na universidade sobre os processos de criação. Na pesquisa sobre arte, por sua vez, estudam-se obras e artistas sob o olhar distanciado da história, crítica ou teoria da arte ${ }^{259}$.

Em um texto bastante citado, chamado "Research in Art and Design", de 1993, publicado no contexto britânico da transformação dos politécnicos (onde as escolas de arte e design estavam alojadas até então) em universidades, e focado em debates pragmáticos sobre financiamento do ensino superior por parte do governo, Christopher Frayling, então professor no Royal College of Art de Londres, cria três categorias para dar conta da pesquisa em arte e em design feita na academia: "pesquisa dentro da arte e do design", "pesquisa através da arte e do design" e "pesquisa para a arte e o design". Essa categorização serviu de referência para várias explorações posteriores sobre os significados da pesquisa no design e recentemente para as discussões renovadas sobre a pesquisa artística. ${ }^{260}$

O historiador da arte James Elkins, professor na Escola do Instituto de Arte de Chicago, faz uma categorização extensa sobre os doutorados em Arte, composta de três modelos propositivos. No primeiro modelo chamado "dissertação ou tese que informa a prática artística”, estes textos apresentam-se como de história da arte, filosofia ou teoria da arte, crítica de arte, de outros campos do conhecimento, ou ainda como um relatório técnico. No segundo

${ }_{259}$ Sandra Rey, Da prática à teoria, 1996, p. 82.

${ }^{260}$ Christopher Frayling, Research in Art and Design, 1993, p. 5. 
modelo: "a dissertação ou tese equivale à obra de arte", o autor destaca a relação arte-pesquisa como um novo campo interdisciplinar e propõe também, em contrapartida, que produção artística e pesquisa acadêmica sejam coisas separadas. Por fim, no terceiro modelo intitulado "dissertação ou tese como obra de arte, e vice-versa", o texto é lido como arte e a prática artística como pesquisa, e também, no limite, que produção artística e pesquisa estão de tal maneira fundidas, que não se exige um texto ${ }^{261}$. Elkins centraliza suas atenções sobre teses e dissertações de artistas, porém sua classificação será estendida a partir de um entendimento mais amplo de pesquisa artística na universidade, aquela que é realizada por artistas que são mestrandos, doutorandos, pesquisadores de pós-doc, professores-pesquisadores-orientadores, em grupos de pesquisa, nas mais variadas atividades de pesquisa ou divulgação acadêmica.

Henk Borgdorff, professor na Academia de Artes Criativas e Cênicas (ACPA) da Universidade de Leiden, na Holanda, inspirado em Frayling, também propõe três categorias para a pesquisa artística: a "pesquisa sobre as artes" faz uma reflexão interpretativa próxima da tradição das ciências humanas mas com o objetivo de produzir arte; a "pesquisa para as artes", faz seus estudos técnicos, instrumentais e sobre a tecnologia com o objetivo de serem aplicados na criação; e a "pesquisa nas artes" não faz separação entre a discursividade do texto e a experiência da produção artística, sendo que o resultado não pode ser determinado como somente prático ou teórico ${ }^{262}$.

O texto "Artistic Research and the Poetics of Knowledge", de Kathrin Busch, pesquisadora e professora da Universidade de Artes de Berlim (UdK), elenca nove aspectos sobre as novas relações da arte com a pesquisa, a teoria, as ciências e a filosofia, dentro do fenômeno da pesquisa artística, tal como vem sendo pensada nos últimos anos e intensificada nos debates em torno da Declaração de Bolonha ${ }^{263}$. O texto apareceu pela primeira vez na publicação do projeto formado por exposição e simpósio chamado "A Portrait of the Artist as a

261 James Elkins, Positive Ideas for PhD Programs, 2014, pp. 309-324.

${ }_{262}$ Henk Borgdorff, The Debate on Research in the Arts, 2012, pp. 37-39.

263 A autora, ao constatar o fenômeno a partir da Declaração de Bolonha, não deixa de colocar em dúvida se a reestruturação acadêmica promovida foi adequada para o próprio campo da pesquisa artística na universidade, considerando que o conhecimento tratado como mercadoria é um ponto a ser criticável. 
Researcher"264, com curadoria de Dieter Lesage e Ina Wudtke, que aconteceu em dois momentos, um em 2007 no MuseumsQuartier de Viena, e o outro em 2008 no centro cultural Beursschouwburg, de Bruxelas. A autora faz categorizações com um entendimento ampliado de pesquisa artística, ajudando a distinguir as diferenças entre pesquisas do artista feitas no meio acadêmico daquelas feitas de forma independente, em outros circuitos e instituições da arte. Percebe-se que a primeira, a quarta, a sexta, a oitava e a nona categorias, chamadas "arte com pesquisa", "pesquisa artística como disciplina”, "arte como uma forma diferente de conhecimento", "hibridização da arte com a pesquisa" e "zona intermediária”, apresentam qualidades que ajudam a traçar um caminho que parte da ideia de pesquisa artística na universidade até a ideia de pesquisa artística que circula através de variados circuitos. Já a segunda, a terceira, a quinta e a sétima categorias, chamadas "arte sobre pesquisa", "arte como pesquisa", "pesquisa artística crítica" e "poética do conhecimento", respectivamente, excedem, de fato, o meio acadêmico para falar da arte de forma geral, relacionando-se com outros campos do conhecimento ${ }^{265}$.

Arlindo Machado, professor na Pós-graduação em Meios e Processos Audiovisuais da ECA-USP, em artigo de 2016 intitulado "A pesquisa em arte em três atos", faz algumas considerações sobre a pesquisa do artista. No primeiro ato, a autor chama atenção para o fato de que "não existe arte sem pesquisa", e que alguns artistas colocam uma intenção maior neste aspecto, o que leva ao estudo de técnicas e de tecnologias ou também sobre o tema da obra. O segundo ato fala sobre a "pesquisa que é realizada dentro da própria arte", ou seja, como os artistas, ao se dedicarem ao processo de criação, fazem uma reflexão sobre a própria arte. Por último, no terceiro ato, Machado põe em relevo a "materialidade da pesquisa", ou seja, a importância dos aspectos materiais, "práticos", do fazer que resulta em obras de arte, contrapondo-se ao pensamento que origina textos escritos e teorias de $\operatorname{artistas}^{266}$.

264 O projeto A Portrait of the Artist as a Researcher contou com obras do artista belga Herman Asselberghs, da artista alemã Annette Wehrmann, da artista americana Jill Magid, entre outros. Também contou com as falas do artista alemão Stephan Dillemuth, da pesquisadora alemã Kathrin Busch, do filósofo e ativista belga Lieven De Cauter, entre outros.

265 Kathrin Busch, Artistic Research and the Poetics of Knowledge, 2009.

${ }^{266}$ Arlindo Machado, A pesquisa em arte em três atos, 2016, p. 50. 
No texto de 2016 "Memória e método: complexidades da pesquisa acadêmica em processos de criação”, Lúcia Leão, professora da Pós-graduação em Comunicação e Semiótica da PUC-SP, diz que chegou a três tipos de dissertações e teses de artistas brasileiros a partir de um levantamento em programas próprios de pós-graduação. Existe a "tese memorial”, em que os artistas apresentam sua trajetória artística por meio de narrativas e interpretações; a "tese teórica", que corresponde a trabalhos que se espelham em metodologias existentes, provenientes de áreas com a história da arte, a antropologia etc., em teses e dissertações que são predominantemente teóricas; e a "tese de processos de criação", referência mais interessante para a autora, pois as questões teóricas estão intimamente ligadas à produção criativa, configurando-se a partir de um metodologia plural e aberta ${ }^{267}$.

Após esse panorama e através da análise dos modelos apresentados, será feita uma síntese organizada dessas ideias juntamente com as de outros autores, em sete categorias próprias, criadas para esta tese, importantes para o seu desenrolar, em uma categorização aberta da pesquisa artística. O intuito é ampliar ideias e significados para além do meio acadêmico, ou antes, imaginar uma conexão entre variados circuitos, contextos e instituições, colocando as questões da pesquisa artística sobre a própria criação artística, independente de seu lugar institucional de produção ou exibição, em um tipo de abordagem em que é destacado o projeto poético do artista orientado à pesquisa.

A seguir, são listados sete estados da pesquisa artística, estados elementares - e até institucionalizáveis -, porém abertos, que não ocorrem como oposições, posto que não são desconsiderados os cruzamentos criativos entre tais qualidades e frequências, ou a passagem de um estado a outro, em modo sincrônico, em livre trânsito combinatório. São estados que se exibem com mais projeção nesta tese, ou na arte de agora lida por esta tese, o que não deve impedir que outros estados sejam pensados e propostos ${ }^{268}$. Utiliza-se aqui a palavra "estado" em um entendimento que se conecta à ideia de "estado de

${ }^{267}$ Lucia Leão, Memória e método, 2016, pp. 120-121.

268 Um outro estado a ser colocado poderia ser o da pesquisa artística coletiva/ de grupo, seguindo a sugestão de Gilbertto Prado, cuja participação encontra-se no Anexo 1 desta tese, questão que merece uma nova pesquisa. 
invenção" de Hélio Oiticica ${ }^{269}$. Isto posto, são delimitadas sete fronteiras com linhas tracejadas, ou seja, sem a utilização de cercas ou muros: 1) pesquisa do artista na universidade, 2) pesquisa de produção artística, 3) pesquisa em arte e tecnologia, 4) pesquisa do artista sobre a própria arte, 5) pesquisa teórica de artista, 6) pesquisa do artista associada a outros campos, 7) pesquisa do artista em vários circuitos.

\section{Pesquisa do artista na universidade}

O primeiro estado, aqui chamado de pesquisa do artista na universidade, entra em diálogo com o último item, denominado pesquisa do artista em vários circuitos, não como uma contraposição, mas para demarcar que o artista pode cursar uma pós-graduação e fazer pesquisa, pode continuar pesquisando na universidade sendo ao mesmo tempo artista-professor e artista-pesquisador, mantendo uma atividade de publicações de livros e artigos, seminários e palestras, além de poder circular por outros circuitos como museus, galerias de arte, bienais, centros independentes de pesquisa etc. A importância deste estado concentra-se no estabelecimento de um lugar próprio para a pesquisa do artista dentro da universidade e na nomeação de um curso ou linha de pesquisa próprios de pós-graduação stricto sensu, enquanto disciplina de criação artística e formação voltada à pesquisa.

Muito próxima dos significados propostos aqui neste estado, "pesquisa artística como disciplina acadêmica" é uma das nove categorias criadas por Busch sobre o tema, falando sobre a criação de um lugar para os mestrados e doutorados em arte e a emergência de uma disciplina própria para a criação artística dentro do meio acadêmico. Nesse tópico, a autora aborda os problemas que alguns programas têm em colocar a arte em bases e métodos científicos, ou

\footnotetext{
269 Segundo HO, “A arte só pode ser um estado de invenção, só pode ser uma fórmula de experimentalidade, uma forma de atividade... O experimental é justamente a capacidade que as pessoas têm de inventar sem diluir, sem copiar, é a capacidade que a pessoa tem de entrar num estado de invenção, que é o experimental e ele tem a tendência de ser simultâneo, há vários níveis de experimentalidade, há tantos níveis de experimentalidade quantos indivíduos pode haver (...) a capacidade de experimentar é o que pode fazer com que cada pessoa entre no estado de invenção e daí possa emergir uma coletividade”. Hélio Oiticica, Depoimento concedido a Ivan Cardoso para o filme H.O. [jan. 1979], 2009, pp. 241-242.
} 
de a arte ter de se submeter aos mesmos parâmetros de quantificação adotados por outras áreas das ciências ${ }^{270}$. Ainda que a expressão pesquisa artística seja utilizada de forma geral, ou para falar da atividade de busca do material, da referência ou do assunto para a arte, segundo tanto Holert ${ }^{271}$ quanto Borgdorff ${ }^{272}$, ele serve para diferenciar e conectar os domínios da arte e da academia, cruzamento que é institucionalizado como disciplina acadêmica nas fronteiras entre as práticas artísticas e científicas dentro da universidade, sendo que os limites da arte em relação a outros campos do conhecimento é um dos temas mais discutidos a esse respeito. A aliança entre produção artística e produção científica, uma conexão entre os domínios da arte e da universidade, de início já provoca um primeiro questionamento, o de saber se a arte produz conhecimento e também se é uma área válida de pesquisa. No polo oposto, pergunta-se se a arte ou a liberdade criativa estará ameaçada se colocada em bases e métodos científicos, através da imposição de protocolos e métodos de quantificação. Nesse sentido, é muito difícil a arte querer equiparar-se aos métodos e exigências importados de outras áreas do conhecimento. A suposição é de que a arte só é forma de conhecimento se estiver em conformidade com esses padrões. O processo de criação, a prática e a experimentação artística são combinados com a História da Arte e outros modos do conhecimento para formar um modo próprio de pesquisa. Para Maharaj, essa combinação ultrapassa o modo de pesquisa tradicional, exclusivamente acadêmica ou científica, por isso deve-se ter cuidado em restringi-la a protocolos e a métodos únicos, com o risco de torná-la uma disciplina estagnada ${ }^{273}$.

Em um primeiro momento, porém, a busca de regras e regulamentações pode ocorrer em virtude de uma questão institucional e do problema da equiparidade arte-ciência para atender os mecanismos de validação, para que artistas-pesquisadores e programas de pós-graduação em Arte recebam financiamentos de pesquisas e bolsas de estudo. O ímpeto inicial por trás do estabelecimento da pesquisa artística em relação à geração de novos

\footnotetext{
270 Kathrin Busch, Artistic Research and the Poetics of Knowledge, 2009.

${ }^{271}$ Henk Borgdorff, The Production of Knowledge in Artistic Research, 2012, p. 143.

272 Tom Holert, Art in the Knowledge-based Polis, 2009.

${ }_{273}$ Sarat Maharaj, Unfinishable Sketch of “An Unknown Object in 4D”, 2004, p. 39.
} 
conhecimentos, dentro dos sistemas educacionais superiores, ocorre por uma questão financeira, no sentido que sejam criadas as oportunidades para que a produção artística seja reconhecida como uma nova disciplina pelas agências de fomento. Silvio Zamboni relembra a dificuldade da oficialização de toda a área de artes no CNPq, por volta de 1984, que incluiu não só a pesquisa do artista mas também a pesquisa feita pelos historiadores, teóricos, curadores e educadores das Artes Visuais, além dos pesquisadores das subáreas de Música e Artes Cênicas. A dificuldade se deu, diz ele, pelo fato de as outras áreas científicas terem que compartilhar seus recursos com mais uma nova área, que por consequência arremataria uma fatia das provisões. "Pesquisa é feita com recursos, não só no Brasil como em qualquer lugar do mundo. E a briga entre cientistas , entre áreas, entre laboratórios, entre institutos é ferrenha ${ }^{274 . ” ~ O ~ f a t o ~}$ de que a pesquisa artística é, em muitos casos, um problema institucional, é colocado por Elkins ${ }^{275}$ e Cazeaux ${ }^{276}$, ao perceberem que a movimentação em torno do estabelecimento ou aumento de auxílios e bolsas de estudo ocorre paralela à necessidade de expor as realizações alcançadas por pesquisadores e departamentos, sempre quantificada em números de publicações, congressos e atividades desenvolvidas. Para o desenvolvimento da área, não basta a oficialização e seu posicionamento na universidade, mas uma valorização constante através de provisão de recursos pelas agências de fomento, e o reconhecimento, de fato, de que a arte tem um modo muito próprio de fazer pesquisa.

Irit Rogoff diz que está mais interessada, apesar dos questionamentos ou problemas em torno da pesquisa artística europeia - como saber se ela é um novo paradigma ou se os protocolos acadêmicos tendem a tornar os processos criativos mais burocráticos e disciplinados nas academias de arte tornadas faculdades -, nos esforços de pessoas determinadas em criar um lugar específico para a pesquisa do artista no meio acadêmico, driblando as restrições e os impasses que vão surgindo. A autora também defende que a indisciplina é um modo de a arte encontrar seu lugar nesse meio, para que sejam permitidas

${ }_{274}$ Silvio Zamboni, Situação atual da pesquisa em/sobre arte, 2005, p. 193.

275 James Elkins, On Beyond Research and New Knowledge, 2009, p. 114.

${ }^{276}$ Clive Cazeaux, Art, Research, Philosophy, 2017, posição 289 (e-book). 
novas formas criativas de conhecimento277. A esse respeito Borgdorff diz que "a arte transcende seus limites tradicionais, buscando através da pesquisa contribuir para o pensamento e o conhecimento; a academia, por sua vez, alarga suas fronteiras para modos de pensamento e conhecimento intrincados nas práticas artísticas” ${ }^{278}$.

O problema da pesquisa artística é visto por Elkins, no entanto, de forma diferente. De acordo com ele, mais do que reconhecer que a arte vem se diluindo com outros campos do conhecimento, é preciso compreender que a validação da arte como pesquisa científica na universidade, por parte do restante da comunidade científica, nunca irá ocorrer. Para ele, termos como "pesquisa" e "conhecimento" são problemáticos quando aplicados às artes, embora algumas aberturas tenham sido feitas na História da Arte por Hubert Damisch, Yve-Alain Bois, Hanneke Grootenboer e W. J. T. Mitchell, amparados pela fenomenologia e a antropologia, de modo a imaginar um pensamento incorporado em imagens e em obras de arte, independente do apoio textual. A pesquisa artística deve incorporar o que está fora da linguagem e da lógica, assinala Elkins, pois o que acontece no estúdio ultrapassa, em muitos momentos, as formalizações discursivas, sendo uma atividade que envolve experiências e práticas da ordem do não verbal, do desconhecido, do tácito, do extralinguístico, do não conceitual. No entanto, ele parece desconfiar de muitas de algumas defesas que prescindem de uma reflexão discursiva, ainda que ele perceba muitos artistas trabalhando com a pesquisa como produtora de conhecimento em suas obras, sobretudo quando se trata de coletivos de artistas contemporâneos, como Yes Men e Critical Art Ensemble. Deve-se notar que o autor pode parecer um pouco antiquado ao não querer equiparar a pesquisa artística à produção científica e restringir a arte, em muitos pontos de seu pensamento, a conceitos como expressão, emoção, paixão, prazer estético e significado. "Ninguém fora das artes se vê persuadido por estas definições de pesquisa e "novo conhecimento" que apareceram na bibliografia artística” ${ }^{279}$, diz ele. Porém, deve-se atentar para

\footnotetext{
277 Irit Rogoff, Practicing Research, 2010, pp. 39-40.

${ }^{278}$ Henk Borgdorff, The Production of Knowledge in Artistic Research, 2012, p. 143. (Tradução do autor.) 
a consideração de que o modelo científico não pode ser aplicado a todas as pesquisas do artista realizadas na universidade, uma vez que a arte é plural e aberta, e não pode, por isso mesmo, estar atrelada aos mesmos parâmetros, métodos e protocolos utilizados, por exemplo, pela Sociologia, pela Física ou pela Engenharia. Elkins vislumbra algumas opções para o artista na academia, como a de que a tese ou dissertação é a obra de arte e vice-versa. ${ }^{280}$

A criação deste lugar institucional específico para a pesquisa do artista no meio acadêmico acontece com os esforços de muitos artistas e pesquisadores, em constante tarefa de definição da área e criação de novas metodologias, de modo que a pesquisa artística seja construída como uma nova forma criativa de conhecimento. Sobre a especificidade da área de Artes em relação a outros modelos, protocolos e métodos provenientes das ciências humanas e exatas, Arlindo Machado sustenta que "podemos definir a nossa pesquisa a partir da tradição e das rupturas que vêm de nosso próprio campo de interesse, sem nos deixar afetar por manifestações de incompreensão e preconceito que vêm de outros campos" 281 . Ou seja, a pesquisa artística na universidade é um tipo muito específico de pesquisa, sendo um estado que não empresta, sem contestações, os modelos da pesquisa científica ou próprios de outras áreas, pois se define a partir da tradição da própria arte, de sua história e pelo desenvolvimento muito específico dos projetos poéticos de cada artista que se propõe a pesquisar, criando constantemente novos modelos, de forma mutável, plural e aberta.

\section{Pesquisa de produção artística}

Outro estado da pesquisa artística é, na denominação utilizada aqui, o da pesquisa de produção artística, um tipo de pesquisa que reivindica a obra de arte ou criação artística como o próprio resultado da pesquisa, ou ainda, parte dela quando associada a textos acadêmicos, relatórios, artigos, dissertações e teses, ou a outras atividades acadêmicas. A obra de arte, material ou imaterial, é o elemento principal da pesquisa. Dentro da universidade, possui ligação forte

280 James Elkins, On Beyond Research and New Knowledge, 2009, pp. 114-119.

${ }^{281}$ Arlindo Machado, A pesquisa em arte em três atos, 2016, p. 50. 
com o estado anterior, pois programas de pós-graduação em Arte foram criados para possibilitar a defesa da produção artística, mesmo que essa qualidade não seja preponderante sobre determinada pesquisa ou outra, ou que pesquisas de produção sejam esboçadas em programas de outras áreas. É um dos estados mais comuns e muito discutido no contexto recente europeu porque, caso predomine, privilegia a obra de arte em relação ao texto ou à pesquisa teórica, ou, em muitos momentos, é somente a obra que é defendida.

A entrega de uma produção, em vez de texto ou reflexão teórica, não é motivo de consenso, até mesmo, entre os artistas-pesquisadores. Pois obra de arte por ela mesma poderá defender-se como produto da pesquisa, no limite, sem a ajuda de um texto que a valide, sendo considerada produto autônomo do conhecimento para a área de artes visuais. Frayling possui uma denominação específica para essa característica, que ele chama de "pesquisa para a arte e o design", sendo a pesquisa que objetiva como produto final do conhecimento o próprio artefato, obra de arte, produto ou peça do design, em que o pensamento está incorporado nele, no sentido de comunicação visual, icônica ou imagística. Daí que o objetivo principal não é fazer um relatório verbal sobre a prática artística ou de design, mas apresentar a própria produção. Aqui o autor elabora uma característica que, ainda no limite, é muito difícil de ser aceita nos meios acadêmicos, o resultado de uma pesquisa, publicação, atividades acadêmicas, dissertação ou tese compreendidas pela produção, que prescinde de uma explanação teórico-discursiva, e que se sustenta em uma tradição cognitiva oriunda da própria materialidade artística. Frayling diz que não são oferecidos títulos na universidade para pesquisas em que a "arte fala por si mesma". Nesse caso extremo, o autor diz que "toda a história da arte" seria passível de receber, nestes termos, um título acadêmico de pós-graduação ${ }^{282}$. A ideia de uma obra tratada como o resultado da pesquisa e produtora de novos conhecimentos é vista por Cazeaux ${ }^{283}$ e Maharaj ${ }^{284}$ a partir da constatação de que a pesquisa artística foi desmerecida por outras áreas acadêmicas, dentro desse processo de legitimação por parte das escolas de arte, de encontrar um lugar para a pesquisa

282 Christopher Frayling, Research in Art and Design, 1993.

283 Clive Cazeaux, Art, Research, Philosophy, 2017, posição 295 (e-book).

284 Sarat Maharaj, Know-how and No-How, 2009. 
do artista dentro da universidade. Os autores ampliam tal questionamento para o fato de a defesa da dissertação ou tese em arte ter que se apoiar sempre em um texto. Silvio Zamboni alerta para o fato de que a resposta dada pela pesquisa em arte não é devolvida para a sociedade como texto acadêmico, invenção, descoberta científica ou produto tecnológico, mas sim como obras de arte. Segundo o autor, a pesquisa científica identifica a existência de um problema sobre um objeto a ser estudado, com possíveis respostas claras para esse problema, sobre um método que organiza os processos, trabalhando para ter segurança nos resultados, de forma premeditada e refletida. Mas, se no caso das Ciências, o problema é algo mais fácil de identificar, nas Artes as questões podem não se apresentar de forma tão fácil, suas soluções são mais abstratas ou são próprios do próprio fazer artístico, de sua história ${ }^{285}$.

No início da pesquisa em arte no Brasil os artistas Regina Silveira, Carmela Gross e Evandro Carlos Jardim defenderam dissertações e teses muito próximas da ideia de pesquisa de produção artística, com predominância definitiva da obra de arte sobre o texto teórico ou descritivo, procurando deslocar-se de metodologias de outras áreas. Em 1980 Regina Silveira apresenta Anamorfas, tal como visto no Capítulo 1, resultado da sua pesquisa de mestrado orientada pelo historiador da arte Wolfgang Pfeiffer, composta de um texto descritivo, de álbum com 12 gravuras, e de uma exposição no MAC-USP. Também em 1980, o artista Evandro Carlos Jardim concluirá seu mestrado, orientado por Aracy Amaral, com uma série de gravuras em metal e um texto intitulado "Processos da gravura em metal". Em 1981 Carmela Gross defende, orientada por Walter Zanini, sua dissertação de mestrado com a série de 33 desenhos chamada Projeto para a Construção de um Céu, importante obra para arte brasileira, apresentada no mesmo ano na XVI Bienal de São Paulo. Regina Silveira inaugura em 1984 a pesquisa artística na universidade brasileira realizada em um programa próprio. Em 1987 Carmela Gross defende sua tese de doutorado chamada Pintura/desenho, com uma exposição no MAC-USP. Em 1989 Evandro Carlos Jardim defende suas Reflexões sobre a prática da gravura em metal como tese de doutorado, orientado por Walter Zanini. Todos ${ }_{285}$ Silvio Zamboni, A pesquisa em arte, 1998, p. 6. 
esses exemplos pioneiros têm em comum o privilégio da obra de arte e do processo criativo.

A pesquisa de produção artística acontecerá de forma pioneira também no Reino Unido, sendo o primeiro doutorado prático defendido em 1978, muito próximo da arte tecnológica. Como já citado anteriormente, o modelo britânico foi criado a partir da década de 1970 nos institutos politécnicos, para dar conta tanto da pesquisa feita nas artes visuais, música, artes cênicas e design, e desse modo foram desenvolvidos mestrados e doutorados muito próximos da ideia de prática, a partir do nome histórico "pesquisa baseada na prática”. Por lá, muitos autores desenvolveram as ideias de practice-based research, practice-led research $^{286}$ e practice as research $(\mathrm{PaR})^{287}$, termos também utilizados por agências de fomento, como o Conselho de Pesquisa de Artes e Humanidades (AHRC), do Reino Unido. Outro autor a assinalar esta condição da pesquisa de produção artística é o artista-pesquisador inglês Victor Burgin²88, dentro de sua categorização muito objetiva a respeito do ensino superior, formada por três soluções para o resultado da pesquisa do artista na universidade. Ele define um "doutorado mais identificado com a prática", em que a produção visual e a escrita têm igual peso, em que a defesa é composta de uma tese ou dissertação que "contextualiza o trabalho prático", e de uma produção artística consistente. $\mathrm{O}$ autor propõe que sejam aceitos alguns tipos de pesquisa artística para que se encaixem nos variados tipos de estudantes de Artes no nível de pós-graduação, dependendo de sua destreza ora com a produção artística, ora com o texto acadêmico. O autor sugere também, nesse sentido, um tipo de doutorado em Arte próprio a estudantes que têm pouca aptidão para o texto ou interesse em escrever uma tese longa, para que a ênfase se dê sobre a produção artística289.

O artista José Resende, em um texto sobre a formação do artista no Brasil, publicado originalmente em 1975 na revista Malasartes, em seu primeiro

286 O conceito de practice-led research é desenvolvido em: Carole Gray, Inquiry Through Practice, 1996.

287 Ver: Robin Nelson (ed.), Practice as Research in the Arts, 2013.

288 Conhecido por suas obras fotográficas conceituais e seus textos teóricos sobre arte, Victor Burgin participou das exposições When Attitudes Become Form, em 1969, e Information, de 1970. E professor emérito da Universidade da Califórnia, Santa Cruz e do Goldsmiths, Universidade de Londres. 
número, época em que mestrados e doutorados em Arte estavam sendo gestados no Brasil, esclarece que a arte, em relação a outras áreas, é um campo de "caráter expressivo", e assim, imagina uma formação do artista que seja pensada sobre dois princípios que se relacionam sem predominância e de forma dialética, a "manifestação expressiva" que se dá através do exercício com a linguagem e sua sistematização, e "a especulação teórica", que é o contato do artista com "um repertório de conhecimentos" e de relações interdisciplinares, em relação direta com os exercícios produzidos por ele, agora inseridos em um "um processo cultural" mais amplo. O artista diz que se existe ênfase sobre o exercício com a linguagem, a pesquisa do artista se descaracterizaria para "a verificação - compulsiva - das capacidades expressivas da pessoa”. Porém, se a arte coloca em relevo apenas o contato com outros conhecimentos, há o risco de ela se orientar apenas a problemas que não são seus, sem "convicção na força de significado que constitui o uso da linguagem em si mesmo - o que é, no fundo, negar sua existência enquanto forma de pensamento". ${ }^{290}$

Para a aula inaugural de instalação do Mestrado em Artes Visuais da UFRGS em 1991, a professora Annateresa Fabris escreveu o texto "Pesquisa em Artes Visuais”. A autora defende que o artista é pesquisador de um tipo muito específico, que fica entre a reflexão e a construção da obra de arte. "Não se trata de uma tarefa fácil diante do predomínio absoluto do discurso verbal no âmbito da universidade." Ela explica que as "Poéticas Visuais" eram novas em relação às outras áreas, e não tinham ainda uma quantidade de modelos suficiente ou tradição, como a História da Arte, por exemplo, ou seja, é uma área que estava em construção, aberta a novas definições. Para Fabris, a defesa de uma série de obras acompanhada de um memorial descritivo reduz os significados do trabalho artístico, ainda mais naqueles casos em que o artista parece se apropriar dos métodos da crítica e da historiografia da arte, só que sobre o seu próprio trabalho. O mais importante a se fazer em um programa de pósgraduação em Arte, segundo sugestão da autora, seria a reflexão, feita pelo 
artista, sobre os processos criativos de construção da obra de arte, revelando o método que até então estava subentendido. ${ }^{291}$

Arlindo Machado diz que, nos meios acadêmicos, existe medo e desconfiança sobre a "eloquência das imagens" e a aprovação hegemônica da literalidade, o que faz a comunicação da pesquisa ser sempre um texto escrito, o que o leva a pensar, falando sobre a pesquisa do artista, em uma materialidade da pesquisa. ${ }^{292} \mathrm{O}$ artista Marco Buti, em seu texto chamado "A arte na universidade, A universidade na arte”, de 2009, primeira parte do memorial para obtenção de Livre-docência no Departamento de Artes Plásticas da ECAUSP, questiona qual é a dificuldade em se avaliar um "projeto puramente visual", levando em conta que existem componentes intelectuais na arte, como o desenho considerado pensamento visual, ou a questão do pensamento que existe no projeto da arte, inerente à execução material, onde a "inteligência é solicitada"293. Segundo Henk Borgdorff, desde Alexander Baumgarten e sua ideia de conhecimento sensorial, o conhecimento que está incorporado na arte, como um "pensamento material”, é objeto de reflexão filosófica ${ }^{294}$; por exemplo, em Immanuel Kant, através da ideia de "valor cultural", a qualidade da arte de fornecer elementos para o pensamento, e em Adorno sobre o "caráter epistêmico" e crítico da arte. O autor também cita Jacques Derrida, JeanFrançois Lyotard e Gilles Deleuze para falar sobre o pensamento da arte em contraposição à natureza restritiva do conhecimento intelectual, e também Maurice Merleau-Ponty sobre o conhecimento da arte em proximidade com o conhecimento corporal295. Seguindo sobre essa ideia de conhecimento incorporado na arte, Borgdorff fala em outro texto, chamado "Artistic Practices and Epistemic Things", sobre os significados da pesquisa artística em uma aproximação com dois filósofos da ciência do Instituto Max Planck de Berlim, Hans-Jörg Rheinberger e Christoph Hoffmann, a partir de uma mesa-redonda

291 Annateresa Fabris, A pesquisa em artes visuais, 1991, pp. 17-18.

292 Arlindo Machado, A pesquisa em arte em três atos, 2016, pp. 48-50.

293 Marco Buti, A arte na universidade, a universidade na arte, 2009, p. 118.

294 Ver um panorama histórico sobre as relações entre arte, filosofia e pesquisa artística nos capítulos "The Theories That Wedge Art and Knowledge Apart"e "We Need to Talk About Concepts" em: Clive Cazeaux, Art, Research, Philosophy, 2017. 
entre os três ocorrida em 2011. Rheinberger, na mesa-redonda, disse que o termo pesquisa artística combina os interesses artísticos aos interesses epistêmicos. Daí pode-se imaginar que o seu resultado não é um texto ou qualquer outro tipo de produção, mas a própria obra que tem em si mesma o conhecimento e o pensamento. Indagando se os critérios e métodos da pesquisa acadêmica poderiam se aplicar à pesquisa artística, Borgdorff relembra que há um interesse recente, de vários campos do conhecimento, sobre a prática, que tem inspiração em filósofos como Edmund Husserl, Martin Heidegger e Ludwig Wittgenstein. O autor cita, como exemplos desse interesse renovado pela prática, os "estudos sociais das ciências", desenvolvidos por Bruno Latour, Michel Callon e Karin Knorr Cetina, entre outros, em torno da palavra-chave teoria ator-rede (ANT). Borgdorff também fala sobre a ideia de "sistema experimental" de Rheinberger, em que o experimento é considerado determinante para a pesquisa científica moderna, ao gerar conhecimento a partir de objetos técnicos e de "coisas epistêmicas". O autor também traz a ideia de conhecimento tácito do pensador Michael Polanyi, um tipo de conhecimento que é adquirido através da prática e pela habilidade, implícita e assentada no aparato técnico e no "sistema experimental". Nesse sentido, para Rheinberger, as "coisas epistêmicas" são o entrelaçamento entre coisas e pensamento. Borgdorff diz que o experimento artístico não pode ser comparado ao experimento científico, citando o filósofo Dieter Mersch, para quem experimentos artísticos ao contrário dos científicos não são reprodutíveis. Todavia, o autor relembra que autores como Rheinberger, Latour e Knorr Cetina elevam qualidades até então próximas da arte como instabilidade, indeterminação, intuição, improvisação e até uma certa imprecisão, como qualidades para o novo laboratório científico. Para Borgdorff, o conhecimento está incorporado na prática artística, em seus objetos e seus processos, sendo para ele o tipo de conhecimento com que a arte se preocupa ${ }^{296}$. Também partindo do pressuposto de que o uso das palavras teoria ou prática como oposições não se sustentam mais, o autor propõe uma ideia mais próxima da pesquisa de produção artística, que ele chama de "pesquisa nas artes" ou 
"perspectiva imanente/ performativa". Esse tipo de pesquisa do artista acontece quando não há fronteiras entre a teoria e a prática artística, quando os conceitos e as teorias estão entrelaçados na prática da arte e quando a prática da arte, fundamentalmente reflexiva, produz métodos e conhecimentos incorporados na obra de arte. "Afinal, não há prática artística que não esteja carregada de experiências, histórias e crenças; tampouco teoria ou interpretação da prática artística que não a configure"297.

Uma das três características que Lucia Leão vê a respeito dos tipos de teses e dissertações defendidas no Brasil, e estudadas por ela, pode ser nomeada como "tese de processos de criação" ou "pesquisa de processos de criação realizada por artistas/criadores”. Diz respeito às pesquisas que estão em diálogo com um percurso de criação, vistas pela autora sob um viés de complexidade, emergência e fractalidade: "Parte-se do pressuposto que existe uma relação íntima e indissociável entre o 'fazer-criativo' e o 'fazer-pesquisa'. A teoria de artista que surge a partir de então é reflexo das "descobertas sobre o próprio fazer criativo" e retroalimenta novos experimentos e práticas. ${ }^{298}$ Ainda segundo Lucia Leão, a condição do artista como pesquisador na universidade propicia muitos tipos de relações entre teoria e prática, que não acontecem de forma fixa ou dicotômica. No geral, cursos de mestrados e doutorados e a atividade de pesquisa na universidade dão origem a produções textuais e teóricas. Porém, segundo a autora, aproximando-se de perto da vida do pesquisador, suas atividades acontecem pela prática da escrita, pela prática da pesquisa, pela prática da apresentação e da publicação dos resultados das pesquisas, e ainda pela prática do diálogo público entre pesquisadores: "Existe uma arte de fazer pesquisa assim como existe uma arte de escrever textos e sem o domínio dessas práticas a vida intelectual acadêmica não existiria”299.

Mabe Bethônico, da UFMG, diz que as produções artísticas para a pesquisa do artista no contexto acadêmico "são parte do processo e resultado do trabalho, de modo indissociável". Outros artistas-pesquisadores foram questionados, para fazer parte desta tese, sobre o grau de importância entre

297 Henk Borgdorff, The Debate on Research in the Arts, 2012, p. 38. (Tradução do autor.)

${ }^{298}$ Lucia Leão, Memória e método, 2016, pp. 120-121.

299 Lucia Leão, Memória e método, 2016, p. 122. 
produção artística (obras de arte, projetos, ações, publicação de artista, instalação, performance etc.) e produção teórica (artigos, teses, dissertações, comunicações etc.) como resultado da pesquisa artística. Para Milton Machado, da UFRJ, não há diferença entre produção teórica e produção artística, pois "ambas são Produção. Ambas são Trabalho. O que mais importa é fazer com que a diferenciação produza a diferença, que é o que produz o movimento". Hélio Fervenza diz que no Programa de Pós-graduação do qual faz parte, na UFRGS, "a exposição ou exibição pública da produção artística realizada durante o curso é obrigatória”, no caso de defesa de teses e dissertações. Entre todos os artistaspesquisadores que responderam, nenhum mencionou que a produção artística não é permitida pelo programa, visto que todos eles foram convidados por fazer parte de programas que têm esse plano estabelecido de forma institucionalizada. Tanto Fervenza quanto Livia Flores, da UFRJ, acreditam que as pesquisas artísticas trabalham com conceitos, reflexões e referências artísticas que surgem ou estão em diálogo com a produção artística do pesquisador. Para Livia Flores, idealmente, tanto produção artística quanto produção teórica "têm a mesma importância" como pesquisa do artista na universidade, "embora sejam pesquisas de natureza diversa". Essa diferença também é colocada por Milton Sogabe, pois no programa em que está associado, na Unesp de São Paulo, ele deixa claro que é exigida a pesquisa teórica, "pois a pós-graduação stricto sensu forma um pesquisador e possível orientador de pesquisas teóricas e teórico-práticas”. Uma proposição provocativa foi colocada por Raquel Stolf, para quem a produção teórica, em alguns casos, acaba transformando-se ela mesma em produção artística, quando há "uma intersecção e interdependência” entre elas, no momento em que é permitido "pensar/propor a própria tese/dissertação como trabalho/projeto artístico".30o

A pesquisa de produção artística é um tipo de pesquisa que fica entre a reflexão teórica e a construção de obras de arte. Dentro do panorama extremamente discursivo das pesquisas em ciências humanas, trata-se de uma aventura justificar-se apenas com produção, perante outras áreas do conhecimento como a filosofia, a história e a sociologia. Porém, oposições 
simplistas como teoria-prática em relação ao artista na universidade devem ser substituídas por novas ideias de prática e de teoria. De fato, houve um momento em que foi necessário defender a produção do artista no meio universitário como uma prática válida de pesquisa. Porém, a prática do artista na universidade brasileira não deveria mais ser defendida ou legitimada, já deveria ser compreendida e aceita. Uma questão que surge, por outro lado, é se existe razão, em uma época marcada por obras de arte que trabalham a discursividade e o texto, de defender um modelo prático sobre o teórico e vice-versa, ou ainda se essa questão é pertinente, numa época de diluição de fronteiras e multiplicidade de processos, experiências, produções e ações artísticas. O que é produzido pelas Artes Visuais é a obra de arte, ainda que esta esteja muito distante de uma obra de arte objetual tradicional, já que é composta de objetos, estratégias, métodos e dispositivos artísticos que são da ordem do discursivo. Não faz mais sentido fazer o questionamento da validade da pesquisa de produção artística, pois se corre o perigo de elevá-la à única possibilidade de trabalho da pesquisa artística, fazendo com que sejam esquecidas outras possibilidades de pesquisa, como: aquelas que não objetivam a produção de obras de arte em um sentido objetual ou material; obras de arte que estão no limite com o conhecimento, os processos educativos ou de pesquisa teórica; pesquisas que dão origem a obras completamente constituídas pelo discurso, por textos ou teorias; pesquisas artísticas pensadas de forma híbrida, sem uma preocupação definida com teoria ou prática; e ainda aqueles casos em que a teoria é considerada prática artística. Por isso, o termo utilizado aqui é pesquisa de produção301 artística e não "pesquisa de prática artística”, em uma proposição mais aberta, para fugir das oposições cansadas.

${ }^{301}$ A ideia do artista como produtor de Walter Benjamin tem sido utilizada de forma recorrente nos últimos anos, tal como em: Okwui Enwezor, The Artist as Producer in Times of Crisis, 2004. Ver: Walter Benjamin, O autor como produtor, 2017. 


\section{Pesquisa em arte e tecnologia}

Será utilizada a expressão pesquisa em arte e tecnologia ${ }^{302}$ como uma das denominações para um dos estados da pesquisa artística, dentre os sete propostos aqui, com significados muito próximos do estado anterior, da produção artística, mas de um tipo que se predispõe ao técnico e ao tecnológico, à computação e à engenharia, em que descobertas e construções originadas da produção artística estão muito próximas dos centros de pesquisa, do laboratório tecnocientífico, e mesmo das empresas de inovação. Esse estado também pode dar origem a vários denominações de arte, que podem variar de autor, tipo de arte, tecnologia utilizada, época e contexto, como "arte cinética", "intermídia", "arte cibernética", "videoarte” "computação gráfica”, "arte de sistemas", "arte eletrônica", "arte robótica” ou "cyborg art”, "arte multimídia”, "arte virtual”, "arte digital", "net art" ou "web art", "arte interativa", "new media art", "arte tecnológica" etc. Outros autores e artistas podem nomear o terreno específico das artes visuais que se relaciona com a tecnologia como arte tecnológica ou simplesmente "arte e tecnologia", com o propósito de abranger variados tipos de produções artísticas que vêm se desenvolvendo em variados movimentos, teorizações e definições, com uma história consistente que atravessa o século 20, inclusive no Brasil, e chega até hoje como um campo bem definido de criação. Às vezes apartada do restante da arte, em uma atitude mais engajada sobre a utilização pela arte dos meios tecnológicos, a arte tecnológica é motivo de inúmeros congressos, festivais e exposições, com um número considerável de artistas-pesquisadores, geralmente em proximidade com a universidade, em

$302 \mathrm{O}$ termo também é muito utilizado e presta homenagem ao Instituto de Pesquisa em Arte e Tecnologia (IPAT), um grupo que entre 1986 e 1989 congregou vários artistas em torno da tecnologia e das ciências, tais como Julio Plaza, Paulo Laurentiz, Anna Barros, José Wagner Garcia, Rejane Cantoni, Milton Sogabe, Mario Ramiro, Artur Matuck etc., que circulavam à época por cursos ou escolas que acolhiam ou tinham interesse pela pesquisa do artista, como as Artes Visuais da ECA-USP, a Comunicação e Semiótica da PUC-SP e o Instituto de Artes da Unicamp. 
centros de pesquisa, programas de pós-graduação e até museus que trabalham nessa interface 303.

A bibliografia estrangeira sobre a pesquisa artística criada no ambiente universitário, em nomes como Borgdorff, Biggs e Elkins, também distinguiu uma vertente mais técnica ou tecnológica dentro das caracterizações feitas por esses autores. A ideia de uma pesquisa em arte e tecnologia, próxima da ideia de pesquisa de produção artística, não se restringe ao campo da arte, segundo Michael Biggs, para quem "os projetos baseados na prática são aqueles que incluem um artefato original como parte da produção, em adição ou, talvez, no lugar de uma dissertação ou tese escrita"304, algo que é do interesse de vários profissionais que objetivam a criação de técnicas, procedimentos, artefatos e produtos, trabalhando em laboratórios e em institutos de inovação ligados a empresas, como todos os tipos de designers, mas também arquitetos, músicos, projetistas de software, engenheiros, médicos, enfermeiros e de variadas áreas de pesquisa que têm um interesse no conhecimento aplicado em alguma produção, e é de grande importância o conhecimento que é gerado com a produção. No outro extremo, a pesquisa de produção artística, para o campo da arte e do design dentro do contexto da pós-graduação, pode ter sido um modo de ajudar a validação da pesquisa artística na universidade, naqueles casos em que há uma aproximação da arte com a tecnologia ou, ainda, a pesquisa técnica

303 A bibliografia sobre a pesquisa em arte e tecnologia é ampla, varia com as descobertas e os interesses tecnológicos e artísticos de cada época. Para um princípio de compreensão, ver: Jack Burnham, Beyond Modern Sculpture: The Effects of Science and Technology on The Sculpture of This Century, Nova York, Brazilier, 1968; Douglas Davis, Art and The Future: A History/ Prophecy of The Collaboration Between Science, Technology and Art, Londres, Thames and Hudson, 1973; Arlindo Machado, Máquinas e imaginário: o desafio das poéticas tecnológicas, São Paulo, Edusp, 1993; André Parente (org.), Imagem-máquina: a era das tecnologias do Virtual, Rio de Janeiro, Ed. 34, 1993; Frank Popper, Art of The Electronic Age, Londres, Thames and Hudson, 1993; Diana Domingues (org.), A arte no século XXI: a humanização das tecnologias, São Paulo, Unesp, 1997 (sobretudo os capítulos "Depoimento sobre arte e tecnologia" de Haroldo de Campos e "Primeiros tempos da arte/tecnologia no Brasil" de Walter Zanini); Julio Plaza e Mônica Tavares, Processos criativos com os meios eletrônicos: poéticas digitais, São Paulo, Hucitec, 1998; Lucia Leão, O labirinto da hipermídia: arquitetura e navegação no ciberespaço, São Paulo, Iluminuras, 1999; Lev Manovich, The Language of New Media, Cambridge, The Mit Press/Leonardo Books, 2001; Lucia Santaella, Culturas e artes do pós-humano: da cultura das mídias à cibercultura, São Paulo, Paulus, 2003; Gilbertto Prado, Arte telemática: dos intercâmbios pontuais aos ambientes virtuais multiusuário, São Paulo, Itaú Cultural, 2003; Edmond Couchot, A tecnologia na arte: da fotografia à realidade virtual, Porto Alegre, Ed. UFRGS, 2003; Suzete Venturelli, Arte: espaço_tempo_imagem, Brasília, UnB, 2004; Priscila Arantes, @Rte e Mídia: perspectivas da estética digital, São Paulo, Senac, 2005. 
de materiais. O propósito da pesquisa não é só a elaboração de um texto teórico exterior à própria produção artística, mas abre-se para um campo mais próximo do desenvolvimento ou projetos de produtos e serviços, da área do design, da engenharia e da computação, ou ainda participa de projetos interdisciplinares para novos projetos de inovação, desenvolvimentos de novas tecnologias de informação ou relacionados com a economia criativa.

No esquema amplo proposto por Elkins, baseado em três grandes modelos para a pesquisa artística e seus resultados, existe uma subdivisão da primeira categoria, própria à prática artística e sua exposição em um texto direcionado, em que a "dissertação ou tese é um relatório técnico", no caso dos mestrados e doutorados, mas esta ideia pode ser expandida para qualquer pesquisa artística que se relaciona a tecnologia, documentada em textos acadêmicos. Esse estado pode falar, também, sobre qualquer relação do tipo técnica ou tecnológica, como a investigação sobre técnicas e materiais realizada pelos artistas e designers, por exemplo. O autor não cita o caso da arte tecnológica, nem exemplos em que o design trabalha sobre inovações tecnológicas de produtos e serviços ${ }^{305}$.

Por sua vez, a "pesquisa através da arte e do design", segundo a categorização de Frayling, é menos utilizada e compreensível pelos programas de doutorado do que a versão tradicional da tese teórica, segundo ele, e apresenta dois entendimentos: o primeiro se refere ao trabalho que explora tecnologias e novos meios e toda a pesquisa técnica ou tecnológica sobre o campo da arte e do design, o que pode incluir a pesquisa de materiais; o segundo é historicamente associado à área do design; a pesquisa é entendida como projeto, ou seja, o texto acadêmico tem a função de comunicar os resultados alcançados por um produto, serviço e até uma obra de arte desenvolvidos, documentando o processo de execução e desenvolvimentos, propondo um relatório como se fosse um diário de pesquisa, que expõe o passo a passo da criação306.

305 James Elkins, Positive Ideas for PhD Programs, 2014, pp. 317-318.

${ }^{306}$ Christopher Frayling, Research in Art and Design, 1993, p. 5. 
Uma compreensão tecnológica da produção artística é também percebida por Borgdorff - dentro de sua tripla categorização da pesquisa artística, na sequência das denominações já clássicas propostas por Frayling - no item "pesquisa para as artes", uma pesquisa aplicada que é vista sob "perspectiva instrumental", em que também são abrangidas "a teoria ou pesquisa teórica de natureza exploratória ou aplicada". Nesse caso, a produção artística é aspecto principal e objetivo da pesquisa e, desse modo, são investigados e propostos novos materiais, produtos, ferramentas, aplicações tecnológicas e conhecimentos surgidos do processo criativo. Tanto a pesquisa teórica quanto o conhecimento tecnológico são utilizados na criação. Segundo o autor, essa categoria é perpassada pelo paradigma tecnocientífico, "em que o laboratório, as convenções das ciências exatas e o ciclo empírico de descoberta e validação constituem uma referência para a experimentação nas artes"307.

Slager propõe uma arte, não necessariamente tecnológica, feita em laboratórios experimentais de pesquisa artística objetivando a criação de novos conhecimentos e experiências, como um espaço especulativo, tanto de discussões quanto de produções. $O$ autor imagina que a criação ou a inclusão de metodologias não sejam dominadas somente por modelos originários da história da arte, escapando da dualidade em que produção se opõe à interpretação das obras ${ }^{308}$.

Em um novo modelo de laboratório para a arte de agora, dentro ou fora da universidade, pode-se vislumbrar um novo entendimento da arte, que não vê as relações entre arte e tecnologia apartadas em terreno próprio, compartimentada em uma única categoria, separada de outros circuitos da arte. Propõe-se aqui, de forma prospectiva, que a arte tecnológica aproveite sua competência em ficar sempre na fronteira, para que se dissolva em novas conexões com outros campos e circuitos ainda mais diversos, em cruzamentos múltiplos entre conhecimentos, tecnologias, assuntos, materiais e linhas poéticas.

307 Henk Borgdorff, The Debate on Research in the Arts, 2012, pp. 37-39. (Traducão do autor.) 


\section{Pesquisa do artista sobre a própria arte}

A pesquisa do artista sobre a própria arte é um dos estados fundamentais da pesquisa artística, um empenho metalinguístico309 em compreender o próprio campo e os fenômenos artísticos, uma reflexão do artista sobre sua própria obra e a de outros artistas. Não foram poucos os autores, pesquisadores e artistas que escreveram sobre as artes visuais através dos tempos ou tomaram obras de arte como referências para construir teorias, conceitos e ideias sobre a arte. No entanto, no limite, toda obra de arte pensa, analisa e reprocessa a arte anterior e a de seu próprio tempo, daí que a pesquisa artística pode debruçar-se e desenvolver-se sobre o pensamento que vem da própria produção artística.

Julio Plaza no texto "Arte/ciência: uma consciência", coloca a universidade como um lugar privilegiado das relações “entre o 'fazer' e o 'saber' artísticos”, em um texto marcado pelas aproximações e diferenças da arte com as atividades do filósofo e do cientista sobre o conhecimento, até então mais nítidas nesse ambiente. Para o autor, o processo de produção artística dá origem ao próprio modo de fazer da obra de arte, pois "os artistas querem entender como se processa o fazer, este é seu significado. Este querer-saber-do-fazer é ir ao encontro da metalinguagem própria do artista, ou seja, aquela que diz respeito à Poética como processo formativo e operativo da obra de arte"310.

Um aspecto muito especial que é parte da história e do contexto da pósgraduação em Arte, e que espanta determinados pesquisadores de outras áreas, segundo Sogabe, é o fato de a própria obra do artista-pesquisador, muitas vezes, ser seu objeto de pesquisa, um trabalho de compreender sua própria obra, fazendo conexões com a arte ou outros campos do conhecimento311. Segundo o autor, o artista que tem interesse nesse tipo de pesquisa deve "saber contextualizar historicamente e conceitualmente" sua produção artística em

\footnotetext{
309 Haroldo de Campos utiliza a ideia de metalinguagem, uma das seis funções da linguagem propostas por Roman Jakobson, para caracterizar o trabalho crítico do poeta: "Em primeiro lugar, eu gostaria de assinalar que esta oposição entre 'poetas doutos' (capazes de reflexão teorética ou 'metalinguística', no sentido que a linguística de hoje dá a este último termo) e 'poetas ingênuos' (da 'inspiração', do 'coração') vem de longe”. Haroldo de Campos, Metalinguagem e outras metas, 1992, p. 260.

310 Julio Plaza, Arte/ciência: uma consciência, 2003, p. 46.

${ }^{311}$ Milton Sogabe, Arte e Pesquisa na Academia, 2014, p. 26.
} 
retrospecto, conectando-a "ao conhecimento existente na área, seja através da história da arte, das teorias e críticas de arte e de outras produções semelhantes" ${ }^{12}$. Algumas pesquisas se concentram sobre a obra de arte já produzida, tentando fazer as conexões e classificações necessárias sobre um universo já construído, em um tipo muito comum de pesquisa do artista sobre a própria obra que resulta em um texto retrospectivo de sua trajetória, amparado pela criação de conceitos ou teorizações sobre um corpo de trabalhos. Na classificação utilizada por Lucia Leão, o tipo mais comum de dissertação ou tese é chamado de "tese memorial" e refere-se àqueles textos em que o artista faz um panorama de sua trajetória artística, articulando pensamento conceitual sobre suas próprias obras de arte, geralmente em "tom narrativo" que segue "um fio lógico e afetivo", e as obras aparecem como imagens que entram "em diálogo com as ideias discutidas"313.

A "pesquisa sobre as artes", chamada também de "perspectiva interpretativa" segundo a categorização feita por Borgdorff, pesquisa a obra de arte, mantendo separação e distância teórica entre pesquisador e seu objeto de estudo, em um modo muito parecido com o das ciências humanas e sociais, um tipo reflexivo e interpretativo encontrado em áreas como os estudos teatrais, literários e da mídia, além da história da arte. A perspectiva interpretativa na pesquisa artística, segundo o autor, ocorre quando a teoria fornece uma reflexão sobre a produção artística em processo ou já como obra de arte. Essa reflexão sobre a arte foi feita por disciplinas como a semiótica, a teoria crítica, a sociologia, mas também historicamente feita pela filosofia e história da arte. Para o autor, "Um entendimento dos processos e produtos artísticos a partir de um ponto de vista filosófico, ético, histórico, hermenêutico, reconstrutivo, desconstrutivo ou contextual é, ou deveria ser, parte de qualquer pesquisa artística" 314 .

O estado da pesquisa do artista sobre a própria arte vai encontrar semelhanças com um dos três tópicos de caracterização que Elkins faz sobre os

312 Resposta do artista Milton Sogabe a questões colocadas por e-mail, no Anexo 1 desta tese.

${ }^{13}$ Lucia Leão, Memória e método, 2016, pp. 120-121.

314 Henk Borgdorff, On Theory, Practice and Research in Professional Arts Academies, The

Conflict of the Faculties, 2012, p. 19. (Tradução do autor). 
cursos de doutorado em Arte, denominado "dissertação ou tese que informa a prática artística”, pois abarca resultados da pesquisa que assumem o formato de dissertações e teses teóricas feitas pelos artistas. Esse modelo é ainda visto sob três subaspectos, o da história, da teoria e da crítica de arte. A via mais comum, dissertação ou tese é história da arte", é a da "história da arte" feita pelo artista que recorta outros artistas e períodos em uma leitura que entra em relação com a sua própria prática. Nesse caso, o autor pontua que o estudante de pósgraduação tem que ter um orientador para a prática artística e outro em história da arte, porém há alguns riscos desta opção de pesquisa, como a utilização de um método que não foi feito para uso em obras de arte e sim para compreensão delas; um conhecimento histórico que pode mais atrapalhar do que ser benéfico a projetos em andamento; a revisão da arte feita de modo parcial pelo artista. Na opção "dissertação ou tese é filosofia ou teoria da arte”, Elkins imagina o artista em um departamento de filosofia ou de história da arte, desenvolvendo como que um tipo de "artist's statement" ampliado e conectado com a produção. E, por fim, no tópico “dissertação ou tese é crítica de arte”, há uma combinação de história da arte e teoria da arte, que se colocam no papel de esclarecer a própria prática artística através de uma autorreflexividade, porém um dos riscos é o estudante não estar preparado, em termos do currículo de pós-graduação, a desenvolver esse tipo de específico de escrita, segundo o autor315.

Para destacar-se da história da arte ou da filosofia, da "pesquisa sobre arte" feita por outros pesquisadores, a pesquisa do artista na universidade, enquanto uma disciplina que está em busca permanente de seus próprios métodos de trabalho, cria um nome para si, "pesquisa em arte", para delimitar este lugar único e assegurar a sua importância. Os artistas que se aventuram a fazer um mestrado ou doutorado e fazem uma trajetória ao mesmo tempo artística e acadêmica, ainda que tenham foco maior na produção artística, acabam se aproximando do modo reflexivo do texto sobre a arte, de levantar indagações e questionamentos sobre seu próprio fazer artístico, relacionando seus trabalhos com uma produção atual ou anterior, e ainda propondo ideias e conceitos que permanecem em potência para trabalhos futuros. Sandra Rey, em 
um texto de 1996 chamado "Da prática à teoria: três instâncias metodológicas sobre a pesquisa em artes visuais" faz um alerta, naquele momento, para a necessidade de consolidação da área da pesquisa artística entre as outras áreas já mais estabelecidas, com a interessante diferenciação entre "pesquisa em arte" e "pesquisa sobre arte". A pesquisa em arte, prática de estúdio e reflexão teórico-poética motivada pela própria prática, "delimita o campo do artistapesquisador”, ou seja, é a pesquisa do artista na universidade, tal como foi designada por Zamboni, para particularizá-la de outras pesquisas feitas pelos artistas. Avançando sobre essa ideia, Rey destaca, em contraposição, a "pesquisa sobre arte”, que é a pesquisa do historiador, do teórico e do crítico de arte.316 Esse aspecto é, também, uma das três características que Arlindo Machado vê atuando sobre a pesquisa artística, denominando esse item como "pesquisa que é realizada dentro da própria arte”, ou seja, o artista aproveita o mestrado ou doutorado para fazer uma reflexão consistente sobre seus trabalhos ${ }^{317}$.

O estado pesquisa do artista sobre a própria arte articula-se com todos os outros, pois a reflexão sobre o campo da arte e a produção artística é essencial para qualquer pesquisa artística, sendo que, em alguns momentos, pode acabar sendo confundido com o estado da "pesquisa teórica de artista" ${ }^{18}$. A pesquisa do artista sobre a própria arte é tanto teórica e discursiva quanto de produção e serve como um contraponto ao estado da pesquisa artística que está interessado também em outros campos do conhecimento. O objeto e o recorte desse estado da pesquisa artística, preocupado em fazer as conexões necessárias para a construção de um projeto poético, concentra-se em compreender e refletir a arte, estudar a própria produção artística e a de outros artistas.

${ }^{316}$ Sandra Rey, Da prática à teoria, 1996, p. 82.

${ }_{317}$ Arlindo Machado, A pesquisa em arte em três atos, 2016, p. 49.

318 Todos os estados podem ter uma predominância de qualidades discursivas e teóricas, assim como também podem ter uma predominância na materialidade da produção artística. Até o estado "pesquisa teórica de artista" tem uma materialidade, quando são pesquisados a publicação ou livro de artista, a palestra-performance ou o vídeo-ensaio, por exemplo. 


\section{Pesquisa teórica de artista}

O estado da pesquisa teórica de artista fala sobre a inserção do artista em uma arena de debates e reflexões teórico-discursivas, seja na universidade, seja em outros espaços e instituições, determinando uma compreensão da pesquisa a partir da leitura de textos e obras de arte, da articulação discursiva em oficinas, palestras e grupos de estudos, do desenvolvimento de escritos e teorias de artistas ${ }^{319}$, da criação de conceitos e sistemas conceituais por parte dos artistas. Parece que esse estado tem as mesmas propriedades do estado anterior, se for levado em consideração que toda pesquisa teórica feita pelo artista poderá ocorrer estritamente sobre o domínio da arte, sem entrelaçamento com outros campos do conhecimento, mas isso seria menosprezar a capacidade da arte de criar simultaneamente vários vínculos. A inclusão desse estado tampouco serve como contraposição ao estado da pesquisa de produção artística, visto que para a arte contemporânea a ideia de produção pode ser considerada de forma mais ampla, nos casos em que a produção teórico-discursiva do artista adentra a própria obra ou se torna parte do projeto poético, e pode ser considerada como obra de arte. Essa delimitação tem a função de designar um estado próprio para a teoria de artista ou para a produção discursiva em proximidade com a produção artística. Na universidade, esse estado pode dar origem a dissertações, teses e artigos. Em vários circuitos, a pesquisa teórica do artista em seu aspecto textual pode ser denominada como teoria de artista ou escrito de artista, podendo ser apresentada de várias maneiras, publicada em vários níveis de institucionalidade, de forma independente ou como catálogo de exposição, na internet ou impressa, como revista e livro de artista etc. O estado também fala sobre o pensamento e as ideias do artista ganhando uma condição pública, seja

319 Escritos de artista aparecem em coletâneas importantes como: Kristine Stiles e Peter Selz (eds.), Theories and Documents of Contemporary Art, 1996; Charles Harrison e Paul Wood, Art in Theory, 2004; Glória Ferreira e Cecília Cotrim (orgs.), Escritos de artistas, 2006; Jennifer Liese (ed.), Social Medium, 2016. 
em uma oficina ou palestra, seja em uma palestra-performance ${ }^{20}$ ou uma oficina considerada como obra de arte.

Na categorização proposta por Frayling, há um item chamado "pesquisa dentro da arte e do design”, que faz uma relação muito ampla sobre a pesquisa do tipo bibliográfica, que parte dos livros, ao abordar tanto a pesquisa "sobre a própria arte", tal como no estado proposto anteriormente, quanto a um tipo de pesquisa teórica próxima dos estudos sociais, econômicos, políticos, históricos, éticos, culturais etc. É uma qualidade que também fala sobre pesquisas bibliográficas feitas pelo artista para o entendimento de técnicas e materiais, não pressupondo uma relação de produção de técnicas ou tecnologias novas, assunto que o autor reserva para outro item. Segundo o autor, é o tipo mais bem assimilado de pesquisa artística, o mais comum no meio acadêmico britânico, tendo em conta as próprias experiências de Frayling no Royal College of Art, entre os anos 1980 e o início dos $90 .{ }^{321}$ De forma semelhante, Lucia Leão desenvolve uma categoria, dentro do seu modelo sobre teses de artista, chamada "tese teórica" para se referir a pesquisas que se apropriam de metodologias de outras áreas do conhecimento, e que podem ser realizadas em outros departamentos da universidade, como os de Filosofia, Educação, Antropologia e História, mas para falar de Arte. O resultado são dissertações e teses que se utilizam de outras disciplinas e metodologias. Produzir arte pode não ser o foco, diz a autora, pois são aprofundadas questões teóricas sobre a obra de arte, a partir de conceitos e métodos pertencentes a outros campos, geralmente das ciências sociais e humanas. "Muitas vezes, nesse tipo de tese, o artista atua como uma espécie de curador e apresenta obras de diferentes artistas e períodos que têm relação com a proposta conceitual escolhida ou com a questão de pesquisa da tese ${ }^{22}$." Victor Burgin também sugere um "doutorado com ênfase

320 A palestra-performance, assunto para uma próxima investigação, possui linhas poéticas próximas da pesquisa artística, dos projetos educativos de artista, e da teoria de artista, parte da prática de uma geração de artistas, tais como Leandro Cardoso Nerefuh, Hito Steyerl, Sarah Pierce, Falke Pisano, Benoît Maire, Nikolaus Gansterer, Xavier Le Roy, Jérôme Bel, Simon Fujiwara, Henrik Olesen, Alexandre Singh, Alicia Herrero etc. Ver: Karen Archey, Performance and Pedagogy, 2009; Patricia Milder, Teaching as Art, 2010; Rike Frank, When Form Starts Talking, 2013.

${ }^{221}$ Christopher Frayling, Research in Art and Design, 1993, p. 5.

${ }^{222}$ Lucia Leão, Memória e método, 2016, pp. 120-121. 
em história e teoria", dentre os três tipos de doutorado em Arte propostos por ele, em que as teses dos artistas possam ter o mesmo peso e as exigências teóricas e metodológicas daquelas feitas nas áreas de humanidades. A ênfase sobre o texto escrito permitiria que o artista-pesquisador também estudasse e colaborasse fora do departamento de Artes, em outras áreas do conhecimento, mas ainda trabalhando a partir de um lugar próprio para a prática artística na universidade, "de modo a fornecer um nível de intimidade com a produção de artes visuais que um departamento tradicional de humanidades não seria capaz de promover". 323 Porém, o autor não especifica se os assuntos abordados nessas pesquisas, efetuadas por esse tipo de doutorado, estariam dentro da arte ou se o artista trabalharia segundo os temas próprios da outra área.

Sandra Rey, para quem os escritos de artista são "ferramentas" de instauração da obra de arte, "tanto quanto o pincel ou o formão para a arte de outrora"324, explora, em um artigo da primeira edição da revista Pós:, da UFMG, o estado dos escritos de artista em relação aos textos produzidos no contexto dos programas de pós-graduação em Arte. Para ela, uma das características da arte contemporânea é a sua relação com a palavra e o texto, algo que sempre fez parte da prática dos artistas que, sozinhos ou em grupos, elaboram proposições artísticas, refletindo "sobre as condições técnicas do trabalho de arte", analisando "a obra de antecessores e de colegas contemporâneos", discutindo “as bases teóricas e pressupostos conceituais do fazer artístico", e também, de forma crítica, o sistema artístico325. Rey evidencia a importância que o manifesto teve para o período da arte modernista, fundamentado teoricamente os grupos de artistas reunidos sobre a nomenclatura de um movimento, como "marcos fundadores de novos procedimentos" e como contestação da arte anterior. A autora percebe a produção teórica e de escritos de artistas não só como uma consequência da pesquisa artística na universidade, mas uma manifestação que vem da arte contemporânea, em um estágio em que técnicas ou estilos específicos não entram mais em questão. "Não é mais imprescindível passar horas a fio a desenhar diante de uma natureza-morta ou de um modelo

323 Victor Burgin, Reflexões sobre "pesquisas" de doutorado em artes visuais, 2013, p. 194.

324 Sandra Rey, A dimensão crítica dos escritos de artistas na arte contemporânea, 2008, p. 14.

325 Sandra Rey, A dimensão crítica dos escritos de artistas na arte contemporânea, 2008, p. 9. 
vivo, mas pesquisas em bibliotecas e arquivos, assim como imersões em laboratórios são cada vez mais importantes", por causa da liberdade, diversidade e heterogeneidade dessas práticas e também da "proliferação de meios e procedimentos". Dissertações e teses são teorias e escritos de artista produzidas na universidade "não só por exigências da natureza do trabalho acadêmico, mas por constatar-se que os conceitos e a reflexão teórica constituem um instrumento interdependente à gênese do trabalho de arte"326.

No livro Teorias da arte, Anne Cauquelin eleva a produção de teorias como um dos domínios da Arte de modo a caracterizar os diversos tipos de gêneros de discursos teóricos. Teoria da arte, para a autora, significa uma "atividade que constrói, transforma ou modela o campo da arte" 327 , e a expressão teorias da arte, no plural, serve para situar cada um dos lugares onde ocorre a reflexão sobre a arte. Esses lugares são divididos por ela em dois tipos, o das teorias de fundação e as de acompanhamento. As teorias de fundação são os pensamentos filosóficos sobre a arte, tal como iniciado pelos gregos na Antiguidade, possuindo ainda outras duas classificações: a primeira, fundada como um horizonte teórico por Platão, é denominada teorias ambientais, pois chega-se à arte não a partir da produção artística, mas pelas ideias e pelo saber absoluto, aí também incluindo Friedrich Hegel e alguns autores românticos; a outra, fundada por Aristóteles, chamada de teorias injuntivas, já que tem um caráter mais concreto de definições e ações para a obra de arte, é uma caracterização que também pode ser aplicada para a estética de Kant e Adorno. Ao lado das teorias de fundação estão as teorias de acompanhamento, que são divididas, por sua vez, em outras duas categorias: as teorias secundárias são contribuições teóricas sobre a arte vindas de outras disciplinas já constituídas, como Linguística, Psicanálise, Hermenêutica, Fenomenologia, História etc.; e, por último, as práticas teorizadas, caracterização onde está localizada a crítica de arte, "exercida por autores literários e que diz respeito a uma obra em particular, às obras de um artista, ou ainda a todo movimento artístico", com uma "tendência clara a filosofar" direcionada à especulação intelectual ou teoria, ${ }^{326}$ Sandra Rey, A dimensão crítica dos escritos de artistas na arte contemporânea, 2008, pp. 1013. 
segundo a autora. Segundo Cauquelin, as práticas teorizadas "nascem ao mesmo tempo em que as obras que sustentam" e estão intimamente "ligadas ao objeto que as incita a existir". Nessa categoria estão incluídos os escritos de artista, "prática interna, imersa na produção, da qual não se separa, resultado da ação dos próprios artistas" 328 . A autora, ao responder sobre o estatuto desse tipo de texto, se são explicativos ou documentais, pedagógicos ou de promoção, comentário ou parte integrante da obra, argumenta que o texto do artista, entre a pintura e o pensamento, a imagem e a palavra, a prática e a teoria, assegura "a intermediação entre o não verbal e o verbal, de maneira a juntar os dois", e assim passa a não responder "mais aos cânones das teorias fundadoras", resistindo à interpretação dos críticos, adquirindo um outro estatuto, pois "passa a fazer parte do dispositivo artístico", tomando a forma de um "textoobjeto"329.

Por sua vez, Fervenza percebe o escrito de artista em relação às experiências e às experimentações. Partindo de uma reflexão sobre o texto-obra "Um passeio pelos monumentos de Passaic, Nova Jersey", de Robert Smithson, o autor diz que os escritos de artista têm a capacidade de registrar a intensidade da experiência ou tornar-se eles próprios experiência. No texto o artista aproveita para fazer um percurso sensível através de uma narrativa que conta com suas próprias experiências. Fervenza diz que o escrito é um material como qualquer outro; os artistas "utilizam a linguagem da mesma forma como poderiam se apropriar de um martelo, um tobogã, uma garrafa, uma tábua de passar roupa”. Em alguns momentos os escritos podem ser próximos ou apropriar-se de algum gênero literário, tais como o diário, a correspondência, a ficção, o manifesto, o ensaio, o texto científico, as notas (de ateliê, de viagem, de ideias), o manual de instruções, entre os exemplos dados por Fervenza, sem necessariamente resultar em literatura 330 .

${ }_{328}$ Anne Cauquelin, Teorias da arte, 2005, pp. 129-130.

329 Anne Cauquelin, Teorias da arte, 2005, pp. 155-157.

330 Fervenza também cita como exemplos de artistas que trabalham com o texto: Hélio Oiticica, Daniel Buren, Dick Higgins, Paulo Bruscky, Kasimir Malevitch, Paul Klee, “(...) e a lista é longa”, diz ele. Ver: Hélio Fervenza, Formas da apresentação: experiência, autonomia, escritos de artistas, 2017, p. 107. 
Aproximando a teoria da produção, Elkins delimita uma categoria chamada "dissertação ou tese que pretendem ser arte e prática visual considerada pesquisa", citando exemplos de filósofos e teóricos que fizeram a quebra dos limites entre filosofia, teoria, poesia e artes visuais, como Michel Serres, John Berger e Jean-Louis Schefer. A tese ou dissertação vai ser lida, em igual medida, como ficção e como arte, como experimentação visual e discursiva, podendo defender-se tanto como produção artística quanto pesquisa, e isso, segundo Elkins, pode ser uma "possibilidade radical”. São momentos que falam sobre o questionamento da obra de arte como pesquisa ao mesmo tempo que se questiona a tese ou dissertação como obra de arte. Outro modelo, lançado por Elkins, propõe uma "dissertação ou tese como obra de arte, e vice-versa”, de um modo que texto e obra estejam completamente enredados. Nesse caso, são utilizadas maneiras diferentes de uso de formatos, materiais, modos de impressão e de encadernação, existe um esforço sobre a diagramação de textos e imagens e o uso tipográfico, há a combinação de escrita experimental e ficção, além da criação de esquemas conceituais, ou seja, a tese é tratada como um livro de artista 331 .

Jonathan Dronsfield, avançando sobre esse ideia, faz uma reflexão sobre a exigência de se ter um texto de reflexão crítica ao lado da prática nos programas de doutorado em Arte ou mesmo nos casos em que se privilegia a escrita e a teoria como práticas da pesquisa. $\mathrm{O}$ autor explica as relações entre arte e teoria a partir das duas categorias propostas por Elkins, vistas anteriormente. O autor explica a sua ideia de "materialidade da teoria" a partir dos desenvolvimentos recentes da pesquisa artística nas academias europeias, e faz uma conexão desse fenômeno com a arte conceitual anglo-americana, em nomes como Robert Morris, Art \& Language e Joseph Kosuth, e também em exemplos da própria produção de arte contemporânea, em artistas como Cerith Wyn Evans, Thomas Hirschhorn, Benoît Maire e Hito Steyerl que, segundo ele, "tem feito uso da teoria como material constituinte de suas práticas" 332 , utilizando a teoria como se fosse qualquer outro material artístico. São artistas

$33^{1}$ James Elkins, Positive Ideas for PhD Programs, 2014, pp. 321-322. 
que trabalham imagem e texto até o limite em que ambos se tornam indiscerníveis. Assim, o autor também defende que doutorados em Arte sejam compostos só de texto, mas um texto de outra qualidade, aquele que é ao mesmo tempo teoria e produção artística. Para ele, o uso performativo da teoria pelos artistas revela a materialidade do texto, concede maior controle para o artista sobre a interpretação dos seus trabalhos, testa as fronteiras do que é entendido como arte e mostra a indistinção entre teoria e prática333.

O estado da pesquisa teórica de artista é muito importante para essa tese porque se encontra de forma preponderante sobre a obra e o projeto poético de JMB e RB. Essa qualidade também pode ser vista em diversos outros artistas contemporâneos, inseridos ou não no ambiente universitário, que estão interessados em discorrer teoricamente sobre temas que vêm da sua própria produção artística, mas, sobretudo, de temas urgentes que surgem de um embate da arte com a sociedade, a vida, e outros campos do conhecimento, que publicam textos em revistas ou como livros de artista, que criam escolas temporárias e projetos discursivos como oficinas, aulas e palestrasperformance, que defendem teses e dissertações como resultado das pesquisas artísticas ou como obras de arte, que trabalham a materialidade do texto e da teoria, até o momento em que um ambiente teórico e de pesquisa instala-se na obra de arte.

\section{Pesquisa do artista associada a outros campos}

A pesquisa do artista associada a outros campos acontece quando o artista começa a se interessar pelos mais variados campos do conhecimento334, pertencentes, por exemplo, às ciências humanas e sociais, às ciências da vida, às ciências agrárias, em um interesse que pode se tornar assunto da arte ou matéria de pesquisa, ou fornecer ferramentas, formatos, métodos e processos de pesquisa, até então estranhos ao próprio campo da arte. O estado pode ocorrer em dois tipos: no primeiro, aqui chamado de pesquisa quase artística, os modos

333 Jonathan Lahey Dronsfield, Theory as Art Practice, 2009.

334 Pode ser pelas tecnologias, as engenharias e a computação, tal como foi visto no estado específico chamado pesquisa em arte e tecnologia. 
de fazer seriam idênticos ou muito próximos aos utilizados nas outras disciplinas. Esquecem-se os procedimentos próprios da arte até a marca em que sobra muito pouco da obra, da artisticidade ou da produção artística, que se perde ou se dilui nessa conversa com a outra disciplina, quase tornando-se outra coisa, no limite com a ciência ou o outro conhecimento. No segundo tipo, denominado aqui como pesquisa poética associada a outros campos, é inventado um modo de fazer muito parecido ao do outro campo de conhecimento, como um método transfigurado e poético, em que a arte se disfarça de política, de etnografia, de história, por exemplo, reproduzindo e adaptando técnicas, formas, estratégias, dispositivos etc., que são específicos da outra área do saber. Entre o primeiro e o segundo tipo é claro que há gradações e misturas. $\mathrm{O}$ artista pode debruçar-se sobre um evento histórico, por exemplo, pesquisando arquivos relacionados ao fato, e de forma muito próxima da disciplina da História fazer descobertas e criar novas interpretações, de maneira tão consistente quanto um historiador faria, mas perpassadas pelo registro poético das Artes Visuais e com a potência da linguagem que lhe é inerente.

A pesquisa do artista, muitas vezes, mesmo no Brasil onde há hoje diversas universidades com programas próprios, acaba acontecendo em outros departamentos ou programas, sendo o mais comum a História da Arte, e então a Arquitetura, a Comunicação, a Filosofia, os Estudos Culturais etc. Sogabe adverte que "o contexto que vivemos é o interdisciplinar, e da visão sistêmica", partindo do princípio de que é impossível um artista-pesquisador hoje não "fazer conexões com outros campos do conhecimento". Por isso, muitos programas interdisciplinares vêm surgindo nos últimos tempos, e desse modo existem "não só artistas em todas as áreas, como profissionais de outras áreas nos programas de arte" 335 . Fervenza diz que essa busca do artista por outros áreas acadêmicas ocorre por uma questão prática e nem tanto por uma demanda que parte da produção artística. Ele elenca vários motivos para o artista não estar em um programa próprio para ele, como não ter o curso em uma cidade próxima, ter dificuldades em "fazer um projeto de pesquisa em arte”, por não saber "teorizar a partir da própria obra" ou não ter um número 
consistente de obras. Fervenza também cita o problema de encontrar um orientador, seja pelo número reduzido de vagas, seja pela afinidade336.

Os temas a serem pesquisados pelos artistas podem ser os mais variados e vir de várias áreas do saber. Arte não existe sem pesquisa, reconhece Arlindo Machado, e esse é um dos três modos que o autor percebe sobre a pesquisa artística. Nesse caso, o trabalho de investigação pode acontecer sobre alguma questão técnica ou tecnológica, seja sobre materiais que serão utilizados na arte, da pedra à linguagem de programação, seja sobre questões filosóficas ou estéticas, com a fenomenologia para a abstração, e ainda em torno do próprio tema da obra, surgido de infinitas fontes, de uma infinidade de tópicos, sendo que todo ou qualquer objeto poderá ser um motivo da produção artística337.

No primeiro modelo que Elkins propõe aos doutorados em Arte, em que são evidenciados o texto escrito e a reflexão, há uma subdivisão chamada “dissertação ou tese é história natural, ou economia, etc.”. Isto é, a Arte relaciona-se com outro campo do conhecimento, para além das ligações tradicionais entre Filosofia ou História da Arte, encontrando-se com as mais variadas áreas das Ciências, a Biologia, a Etnografia, a Geociências e, quem sabe, a Medicina. "Do meu ponto de vista, uma dissertação ou tese científica ou não artística, com o objetivo de promover uma prática artística, é uma perspectiva fascinante338." Porém, o autor pontua que, caso a pesquisa seja avaliada de acordo com os protocolos de outras disciplinas, essa avaliação deixará de ser somente artística, posto que a dissertação ou tese será equivalente às da área em questão. Um risco para essa combinação interdisciplinar que dilui as fronteiras arte-ciência seria a faculdade de arte desempenhar um papel secundário ou ser deixada para trás nessas novas relações339. O segundo modelo, dos três propostos por Elkins, denominado "a dissertação ou tese equivale à obra de arte" (fala como texto e obra estão relacionados de forma mais estreita, com um grau de equivalência maior), apresenta duas subdivisões. Uma parece resolver a questão anterior; a outra,

\footnotetext{
${ }_{336}$ Resposta do artista Hélio Fervenza a questões colocadas por e-mail, no Anexo 1 desta tese. 337 Arlindo Machado, A pesquisa em arte em três atos, 2016, pp. 45-46.

338 James Elkins, Positive Ideas for PhD Programs, 2014, p. 316. (Tradução do autor.)

339 James Elkins, Positive Ideas for PhD Programs, 2014, p. 317.
} 
chamada "pesquisa e obra de arte constituem-se como novo campo interdisciplinar" coloca mais dúvidas sobre as relações interdisciplinares efetuadas a partir da arte. Para o autor, essa subcategoria é problemática porque a prática artística foi historicamente menosprezada pelos círculos acadêmicos; além disso, pode ainda deixar mais confusas as diferenças históricas entre a pesquisa do artista na universidade, que propõe uma obra de arte como um outro tipo de conhecimento novo, da pesquisa efetuada em departamentos e centros de pesquisa científicos. Isso porque, nesse tipo de abordagem, a obra de arte, ainda que trabalhada de forma inter, extra, pós, transdisciplinar, tem ainda por objetivo a criação e apresentação de obras de arte. Um modo de resolver isso é colocado pelo autor ainda neste segundo modelo que fala da equivalência entre obra e pesquisa, na subdivisão que propõe que "pesquisa e obra de arte são projetos separados", que disciplinas não artísticas e práticas artísticas atuem no resultado final de forma independente. $\mathrm{O}$ autor dá o exemplo de uma pesquisa dedicada ao estudo do pós-estruturalismo em paralelo à produção de videoarte. Tal categoria pode ser exemplificada através de várias combinatórias, como uma pesquisa de produção artística sobre gravura, instalação, crítica institucional etc., podendo acontecer de forma paralela e independente a uma pesquisa específica sobre algum fato histórico brasileiro ou uma pesquisa sobre agricultura, urbanismo, bioengenharia etc. De forma que, ao final, os cruzamentos entre produção de conhecimento científico e produção de conhecimento artístico se entrelacem, mas sem que seja exigido pelo programa, na defesa final, uma conexão tão explícita entre as duas investigações, o que acarretaria em um uso mais intensivo dos recursos da universidade por parte do artista340.

O primeiro tópico proposto pela categorização de Busch sobre a pesquisa artística chama-se "arte com pesquisa" e tem alguns significados úteis para o estado discorrido neste momento. Nessa categorização proposta pela autora, a ciência ou a filosofia dão recursos ou fundamentam obras de arte e movimentos artísticos. Aqui a autora apresenta dois tipos de exemplo: o primeiro seria o de conhecimentos científicos como ótica, teoria das cores ou anatomia, que vão 
auxiliar na criação das obras e nos estudos dos artistas sobre cor e desenho; o segundo exemplo trata de como autores e correntes teóricas, sendo estas científicas ou filosóficas, tais como a Psicanálise, a Fenomenologia e a Linguística, vão embasar os discursos de alguns movimentos como surrealismo, o minimalismo e arte conceitual.

Busch também pensa mais duas categorias que estão em relação ao que está sendo proposto aqui. Em uma delas, chamada "Hibridização da arte com a pesquisa”, o projeto de pesquisa artística opera sobre um campo fluido com a prática científica, em modo inter, trans ou extradisciplinar. Nesse híbrido, formas artísticas consideradas no âmbito da produção de conhecimento contribuem para construções teóricas de outros campos. Nesse ponto, segundo a autora, a contribuição da Arte para o conhecimento não pode ser considerada, porém, de forma tão precisa como o é nas ciências. No tópico chamado "Zona intermediária”, a autora sugere um lugar que está entre dois campos, com significados muito próximos do tópico anterior, já que também ficam numa zona entre a pesquisa e a teoria. Porém aqui Busch salienta que o conhecimento é gerado de forma não estruturada, não conceitual e sem cânones. A conversão da Arte em Ciências não resulta na cientificação da Arte, mas antes na criação de um espaço em que Arte e Ciências se conectam ${ }^{341}$.

Em um percurso pela História da Arte pode-se perceber muitas áreas fornecendo conhecimento para o fazer artístico ou apoiando o seu discurso com teorias filosóficas ou científicas. A arte, que sempre esteve em diálogo com a filosofia, vem intensificando suas relações com outras áreas; de um jeito particular e intenso com a tecnologia desde o final do século 19, e desde o final de século 20 com um interesse crescente ou renovado por várias disciplinas, com enfoque específico nas Ciências Humanas e Sociais, como a Antropologia, a Etnologia, a Sociologia, a Arqueologia, o Urbanismo, a História, a Educação etc. É fato que a técnica, a máquina e a tecnologia são assuntos recorrentes, além de fornecer conhecimentos sobre materiais, configuram-se como espaços de experimentações a serem explorados. Porém, a arte pode apropriar-se dos questionamentos feitos em outras áreas, tomar para si estes problemas e 
resolvê-los sob sua própria ótica, suas próprias ferramentas. Há um tipo de pesquisa feita pelo artista que tem uma preferência por debruçar-se não sobre a arte ou os assuntos relacionados com a produção exclusivamente artística, mas sim em direção a outras temáticas, em um plano muito aberto de assuntos e tipos de pesquisa, que revela o artista interessado pela vida, pela história e pelo mundo e, às vezes, até por um conhecimento que não é necessariamente científico, mas de outra ordem: popular, espiritual, comunitário, material, ancestral, não imperialista, não hierárquico, poético.

A partir daí, outras disciplinas ou outros conhecimentos começam a misturar-se de uma forma mais acentuada com a arte, fazendo com que se iniciem uma colaboração e uma construção do conhecimento, que não é igual, é paralela às descobertas e à produção do novo, mais ou menos da forma como ocorreria em seus próprios campos, mas de um modo muito particular e livre. Em outros momentos essa conexão vai aparecer com muita imprevisibilidade, sendo esquecidos tantos os protocolos e as regras do método científico quanto, contemporaneamente, os métodos geralmente utilizado por determinada disciplina. Logo, o uso da ciência, da filosofia ou qualquer que seja o saber envolvido vai se dar poeticamente ou artisticamente sobre seus procedimentos e dispositivos. Uma das características da arte de agora, que acentua uma característica nascida no começo do século 20, com as vanguardas, é a ânsia por relacionar-se fora da arte, rumando para espaços, serviços e atividades até então não associadas com o fazer artístico, em uma exploração sobre o que a arte deve ser, fazendo a leitura do mundo, não só como representação, mas também apoiada pelas ações, pelos acontecimentos, pelas experiências, participação e convivência. $\mathrm{O}$ estado da pesquisa do artista associada a outros campos está circunscrito em um panorama maior de relações históricas e atuais entre Arte e Filosofia ou Arte e Ciência, e tem um foco específico e papel de destaque no fenômeno recente da pesquisa artística, dentro ou fora da universidade, pesquisa que pode estar à margem, institucionalizada ou circulando em variados circuitos, incorporada no projeto poético, na obra de arte mesma. 


\section{Pesquisa do artista em vários circuitos}

Todos os estados apresentados aqui, como modos e frequências, são aspectos intercambiáveis, podem influir uns nos outros. Porém, no caso desse estado, nomeado aqui de forma instável como pesquisa do artista em vários circuitos, todas as outras qualidades podem acabar influindo em sua particularização, pelo fato de que a pesquisa do artista, entre a produção e o teórico-discursivo, entre a arte e os outros campos do conhecimento, não fica restrita necessariamente à universidade ou a uma única instituição somente, ela se desloca de forma independente através de circuitos variados, não se atém a uma única resposta, pode ser criada e exibida sem limitações, pode se posicionar à margem do que já está estabelecido. Muitos autores, principalmente na bibliografia produzida no contexto recente europeu, no intuito institucional de querer formatar uma nova área, o da pesquisa artística como uma disciplina a ser agregada às outras áreas científicas, em um desejo de equiparar conhecimentos e protocolos, acabam deixando de lado, muitas vezes, questões que partem da arte contemporânea. A pesquisa do artista no meio acadêmico traz questionamentos desse meio, desenvolve-se amparada sobre protocolos e regras, guardando conexões com ferramentas, estratégias e metodologias científicas, ainda que esses métodos sejam muito diversos, variáveis de área para área, ou de pesquisa para pesquisa. A pesquisa artística na universidade deve vir, sobretudo, dos questionamentos dos artistas de agora, que não se prendem às instituições, podendo se mover entre galerias, museus, espaços independentes, publicações, grupos, transitando de modo espalhado por variados circuitos e cenas, incluindo aí a academia. O movimento da arte que adentra o ambiente universitário constituindo-se como uma disciplina e área específica na academia é simultâneo a outros dois movimentos: o da pesquisa artística que extravasa a universidade para ser exibida em outros circuitos e o da pesquisa artística que não se origina em programas de pósgraduação, mas no interesse dos artistas pelos processos de pesquisa ou por outros campos do conhecimento. A pesquisa artística não é algo que está apartada da arte, não está restrita apenas ao ambiente universitário ou realizada 
apenas por artistas-pesquisadores universitários, porque são o ambiente de pesquisa e o ambiente teórico que se tornam presentes para o artista em vários lugares e circuitos, reforçando a ideia de que há uma movimentação e um fenômeno da arte de agora sobre o conhecimento e o pensamento.

Segundo Borgdorff, tendo em vista que o discurso da pesquisa artística "é formado pelos discursos tanto do mundo da arte quanto da academia, a relevância desses assuntos e a validade dos resultados devem ser considerados à luz de ambos os contextos" 342 . O autor diz que o mundo da arte também precisa do universo criado pela pesquisa artística, embora ele perceba que exista uma tensão entre o campo da Arte e o da academia. Para que essa tensão se torne produtiva, a pesquisa artística precisa questionar o que é a universidade e a pesquisa acadêmica, assim como também precisa questionar a criação e os métodos de produção artística, para que a pesquisa feita pelo artista na universidade também tenha impacto sobre a arte343.O autor diz que como a pesquisa artística se dirige para ser validada por esses dois mundos, a produção que se desenvolve a partir daí tem que estar em conformidade com os padrões de ambos os lugares. O que não quer dizer que os métodos, os formatos e as estratégias de apresentação precisem seguir os mesmos modelos, pois o artista pode trabalhar com outras formas de discursividade344.

Para Almeida, o fenômeno da pesquisa artística no contexto do qual ela fala, o europeu, ainda não tem um terreno muito sólido para que se torne um campo de interesse para as atividades artísticas paralelas às intenções acadêmicas. Ela diz que a relação entre o mundo da arte e a pesquisa artística foi um assunto menos explorado pelas várias publicações a respeito da pesquisa artística nos últimos anos, e que essa desconexão pode ser a causa do ceticismo vindo do "mundo da arte"345, que acaba se incomodando com as exigências que a posição da pesquisa exige, do artista tendo que se engajar em publicações e seminários, e também por causa de prazos e esforços por produtividade346. A

342 Henk Borgdorff, The Production of Knowledge in Artistic Research, 2012, p. 148. (Tradução do autor.)

343 Henk Borgdorff, Where Are We Today? The State of the Art in Artistic Research, 2012, p. 118.

344 Henk Borgdorff, The Production of Knowledge in Artistic Research, 2012, p. 167.

345 Catarina Almeida, After Artistic Research, 2015, p. 114.

${ }^{346}$ Catarina Almeida, The Problem of Artistic Research, 2015, p. 145. 
autora diz que se faz necessária uma visão sobre a pesquisa artística que tente conciliar esses dois mundos, para que se perceba os processos artísticos que influenciam as circunstâncias do nosso entendimento sobre a pesquisa artística na universidade. E isso também se abre para a compreensão da arte contemporânea, sobre o interesse dos artistas pelas relações entre a arte e o conhecimento, e também os interesses recentes dos artistas pela conversa e pela participação, uma ideia de arte contemporânea que percebe na participação as categorias expandidas para a reconfiguração dos museus de arte como equipamentos políticos e pedagógicos ${ }^{347}$. Além disso, a pesquisa artística não é só um fenômeno acadêmico, mas pode ser visto hoje como parte do projeto poético de muitos artistas.

RB é um dos artistas e pensadores atuais que pensam a arte a partir da ideia de circuito(s), ao mesmo tempo que reflete sobre como se dão as ligações entre circuitos diversos e os impasses surgidos das diferenças entre métodos, propósitos e posicionamento, muitas vezes antagônicos e conflitantes. RB nos lembra que as noções de circuito e sistema da arte foram criadas pelos artistas entre os anos 1960 e 1970, influenciados pelo campo da cibernética, porém o artista avança sobre essas ideias, mostrando um interesse muito específico sobre a economia desses circuitos: "O circuito de arte também está submetido a uma série de mecanismos reguladores que administram sua economia interna, o caminho de circulação da obra, dos valores, os jogos de poder, etc.” ${ }^{348}$. Nesse sentido, RB também relembra o papel que autores como Ronaldo Brito e Paulo Venâncio Filho tiveram na problematização sobre a construção de um circuito de produção da arte contemporânea brasileira, em um sentido crítico, diante do crescente mercado da arte. Circuito era uma das ideias principais formuladas pelo grupo que se formou em torno da revista Malasartes, no Rio de Janeiro, em nomes como Waltercio Caldas, Cildo Meireles, José Resende, Carlos Zilio, entre outros. Foi Brito quem trouxe para o grupo essa ideia de forma mais

347 Catarina Almeida, The Problem of Artistic Research, 2015, p. 140.

348 Ricardo Basbaum, O papel do artista como agenciador de eventos e fomentador de produções frente à dinâmica do circuito da arte, 2002, pp. 104 e 109. 
organizada, diz Zilio, embora "fosse algo que todos intuíam"349, por isso o texto "Análise do circuito", de Brito, foi escolhido para abrir o primeiro número350 "como uma espécie de editorial de apresentação da revista" 351 . O texto de Brito, tentando mostrar que circuito e mercado de arte não são uma coisa só, mobilizava os artistas a "defender um campo de ação mais livre para os seus trabalhos" e a formular "estratégias de ação dentro do mercado e do circuito", procurando multiplicar "discursos críticos" e mover-se livre "dentro do sistema estabelecido de arte”. Para isso, o autor propõe saídas, através da organização de grupos de artistas "em torno de um programa comum de ação dentro do circuito", como estabelecer uma relação maior entre a arte e a universidade, os espaços públicos, as instituições e o restante da cultura, criando interesse em um público de estudantes ${ }^{352}$. Segundo Zilio, foi criado um debate novo no Brasil em torno da palavra-chave "circuito", que alertava para a estrutura hierárquica da arte, composta de muitos agentes, e provocava questões que não eram frequentemente colocadas e refletidas, como saber que "entre o artista e o público existem várias instâncias, como museus, escolas, mercado"353, e que esses agentes "influem ideologicamente sobre o significado da obra", por isso a necessidade, naquele momento, de pensar em políticas "para fazer frente ao que seria uma tendência à institucionalização da arte", como uma "necessidade de politização da prática cultural"354.

Em um primeiro momento, a ideia de artista-pesquisador de RB pode servir para falar do artista que está ligado apenas ao circuito universitário da pesquisa em arte. Colocando sua própria experiência no desenvolvimento da ideia e ressaltando o número significativo de artistas trabalhando sobre

349 Cildo Meireles sobre Inserções em circuitos ideológicos: projeto Coca-Cola, obra de 1979: "Descobrir novos circuitos, descobrir melhores maneiras de gravar as inserções, executar e divulgar constantemente inserções em circuitos ideológicos é a realidade deste trabalho". Cildo Meireles, Quem se desloca recebe, quem pede tem preferência, 1975, p. 15.

$35^{\circ}$ O primeiro número de Malasartes também trouxe o texto "Formação do artista no Brasil" de José Resende, mencionado anteriormente neste Capítulo.

351 Carlos Zilio, Fernanda Lopes Torres e Martha Telles, A formação de um pensamento contemporâneo de arte no Brasil dos anos 1970 (Entrevista), 2014, p. 9.

352 Ronaldo Brito, Análise do circuito, 1975, p. 6.

353 Carlos Zilio, Fernanda Lopes Torres e Martha Telles, A formação de um pensamento contemporâneo de arte no Brasil dos anos 1970 (Entrevista), 2014, p. 8.

354 Carlos Zilio, Fernanda Lopes Torres e Martha Telles, A formação de um pensamento 
questões contemporâneas na academia, dentro do contexto brasileiro, o artista ressalta no texto "O artista como pesquisador" as novas funções acadêmicas específicas atribuídas ao artista, como a aula, a orientação, a participação em grupos de pesquisa e congressos e até mesmo a ocupação de cargos administrativos, ou seja, atribuições que ultrapassam as funções de um artista dentro do circuito da arte habitual355. Para a construção da imagem desse artista, a academia é apenas mais um lugar dentre uma multiplicidade de circuitos e redes artísticas em que ele pode deslocar-se, o que não pressupõe que o pertencimento a um circuito garanta a inclusão em outro circuito, por conta de valores e modos de validação diferentes.

Mas RB reafirma que as diferenças entre os circuitos são produtivas e que a universidade como "outro território" para a arte é um ganho, ainda que o desafio de deslocamento seja maior, pois os produtos da pesquisa em arte podem ficar restritos a uma validação e legitimação apenas por critérios acadêmicos, se não houver o estabelecimento de mais conexão com outros territórios, e para que não haja um isolamento, deve haver mais abertura para outros circuitos da arte: "Seria interessante vislumbrar o espaço universitário sob uma contaminação de fazeres-saberes que gradualmente instalasse uma prática de valores decorrentes das formas de ação da arte contemporânea" 356 . Reivindicando que a prática da arte contemporânea aproxime-se da prática da pesquisa, RB acrescenta mais uma peça a essa imagem do artista-pesquisador construída por ele, associando-o com uma figura mais moderada do "artista-devanguarda”, personagem agora sem o peso utópico e evolutivo dos movimentos, mas aquele que inventa o novo e avança sobre a vanguarda do conhecimento artístico. "Sob esta caracterização, a universidade surgiria como possível espaço por excelência da criação artística357." Essa ideia também reforça a ligação dos estados da pesquisa artística, tal como propostos aqui, com o "estado de invenção" imaginado por Hélio Oiticica, uma "fórmula de experimentalidade"

355 Ricardo Basbaum, O artista como pesquisador, 2013, p. 193.

356 Ricardo Basbaum, O artista como pesquisador, 2013, p. 197.

357 Ricardo Basbaum, O artista como pesquisador, 2013, p. 199. 
que faz "emergir uma coletividade" 358 . Uma pesquisa artística de vanguarda hoje, segundo RB, não pode se colocar à frente se não estiver envolvida com os questionamentos sobre a sociedade, os circuitos e suas relações. O movimento que faz a arte contemporânea adentrar a universidade e transformar "certos hábitos normativos próprios do espaço acadêmico, que frequentemente impedem a emergência de processos", também é aquele que faz as questões teóricas e de pesquisa adentrarem o campo do circuito tradicional da arte, aquele das galerias, centros culturais e museus, "produzindo a possibilidade de um lugar em que os projetos de intervenção (obras e demais variações) sejam portadores de uma dinâmica de pensamento interessante e potente"359. Desse modo a obra de arte vai ser definida "nas relações com seu próprio circuito, e se abrir para um jogo interdisciplinar abordado através de diversas áreas do conhecimento"36o. Ao resgatar a figura do artista de vanguarda, RB acaba resgatando certas qualidades e estratégias atribuídas à arte do século 20 como a experimentação, o laboratório e também o manifesto artístico considerado como teoria de artista, utilizadas por vários movimentos e artistas de vanguarda que tiveram uma produção que pode ser considerada de pesquisa artística, em proximidade com outros campos, sobretudo da Engenharia, da Matemática, da Filosofia e da Literatura.

As ideias de RB sobre o artista-pesquisador ampliam a ideia do que pode ser a pesquisa artística, que às vezes fica restrita à produção da arte nos meios acadêmicos, uma vez que um fluxo entre academia e outros circuitos de legitimação da arte pode acontecer. O artista-pesquisador é aquele artista que está na academia, produz obras de pesquisa, e está aberto para a relação com outros circuitos. A academia é só mais um lugar para a sua atuação. Um outro modo de artista-pesquisador é aquele artista que não está na universidade, mas trabalha com o conhecimento, a teoria, sobre outros campos do conhecimento, ou seja, tem um interesse e uma produção que parte de uma pesquisa não necessariamente institucionalizada.

${ }_{358}^{8}$ Hélio Oiticica, Depoimento concedido a Ivan Cardoso para o filme H.O. [jan. 1979], 2009, p. 242.

359 Ricardo Basbaum, O artista como pesquisador, 2013, p. 201.

360 Ricardo Basbaum, Circuito de arte em deslocamento, 2003. 
Uma das condições para o artista do século 21, segundo $R B$, é "a possibilidade de deslocamento por diferentes papéis e locais do circuito de arte", sozinho ou agrupado em coletivos, desenvolvendo várias práticas, atividades e eventos de "agenciamento, curadoria e crítica" que se aliam à "elaboração discursiva e conceitual” sobre o fazer artístico, como organizar exposições, manter espaços independentes, publicar revistas e projetos editoriais, fazer "mediações discursivas de modalidade crítica, conceitual, teórica e histórica" 361 , oferecendo aulas oficinas e palestras, escrevendo textos e também, pode-se dizer, engajando-se com a pesquisa. Pode-se falar sobre circuito, no plural, porque a ideia de circuito não se refere somente às feiras e às galerias de arte, mas tenta abranger diversos lugares de atuação para o artista, também partindo da premissa de que a ideia de obra de arte hoje é mais ampla e não fica restrita somente à exibição. "Obras de arte (... ) são manifestações de grupos”, diz RB, esclarecendo que o circuito da arte, "seja local ou global", é complexo e enredado, cheio de participantes, "mobilizando em torno instituições, mercados, redes", "composto por diversas comunidades", por "circuitos plurais", onde se encontram "grupos diversos, articulados em políticas comuns, plataformas de ação ou mesmo pesquisas de linguagem" 362 . Por isso, o circuito da arte sistema, mundo, cena etc. - não está restrito a uma única possibilidade de atuação, fato que proporciona os artistas permanecerem instigados a "tecer outras conexões, desfiá-las, atar e desatar nós, movendo-nos em grupos e coletivos, propondo alianças ou produzindo desvios"363.

Às vezes $\mathrm{RB}$ utiliza a palavra circuito em um sentido mais restrito, para significar os lugares tradicionais que compõem esse mundo, como galerias, feiras, revistas, museus de arte etc. Em outros momentos ele utiliza a ideia de circuito, ou no plural, circuitos, para indicar a variedade e a diversidade de lugares e agrupamentos que podem estar disponíveis para os artistas e que não estão atrelados somente aos lugares institucionalizados de exibição e mercado da arte: 'Seja 'oficial' ou 'alternativo', tudo são circuitos - diferindo entretanto em termos de amplitude, maleabilidade, alcance e fluência das conexões (...)

${ }^{661}$ Ricardo Basbaum, Deslocamentos rítmicos, 2008, p. 63.

362 Ricardo Basbaum, Em torno do "vírus de grupo", 2010, p. 144.

363 Ricardo Basbaum, Deslocamentos rítmicos, 2008, p. 65. 
(isto é, ligações fortes, fracas, estáveis ou instáveis, conforme o caso)”. Essa ideia de circuito de RB está inserida em uma "compreensão política das dinâmicas afetivas, quando se tem a amizade como forma política de construção da proximidade na distância”, percebendo que diferentes grupos de artistas, críticos, curadores etc. podem criar variados circuitos, movidos pela "política de alianças entre aqueles que vibram na dimensão de um combate que é aquele da dinâmica produtiva das ações coletivas"364. A obra de pesquisa trabalha e funciona com outros modos de exibição, sendo que até a exibição dos resultados, muitas vezes, não são os acontecimentos mais importantes para esse tipo de obra de arte. A obra que tem o seu privilégio na pesquisa artística espalha-se em variados circuitos, pessoas, conexões, contatos, pensamentos, textos, falas, conversas, e não fica restrita apenas a um circuito, apenas a um modo de exibição e disseminação. Assim, o entendimento de pesquisa artística nesta tese direciona-se para a obra de arte, não só uma questão sobre os circuitos e as instituições, mas com uma questão sobre seu funcionamento como obra de pesquisa. 

CAPÍTULO 4

VOCÊ GOSTARIA DE PARTICIPAR DE UMA

EXPERIÊNCIA (PESQUISA) ARTÍSTICA? 



\section{Como funciona a obra de pesquisa?}

Para entender o funcionamento da obra de pesquisa, que é composta de conexões e associações, linhas de pensamento e objetos, experiências e experimentos, ações e atividades, participações e colaborações, trabalhos e exercícios, processos de pesquisa acadêmica e artística, fluxos de energia e movimentos, é preciso fazer uma tentativa de exibir e descrever as muitas camadas complexas que formam esse tipo de obra. A obra de arte é esquematizada como um projeto (poético) de pesquisa, em que são lançadas as bases teóricas da pesquisa artística em desenvolvimento, processo que é esquematizado segundo um sistema conceitual organizado em tópicos e conjunto de ideias, compondo-se, muitas vezes, de problemas, hipóteses, objetivos, fundamentação teórica, em proximidade com a pesquisa acadêmica, aproveitando-se, de forma poética, de seus protocolos, visualidades e métodos. Essa estratégia fronteiriça é encontrada, às vezes sem distinção, na dissertação e na tese, nos artigos, escritos e teorias de artista, nas conversas e oficinas, nos dispositivos que o artista inventa para fazer circular pensamentos e sensações.

Se Projeto Matéria, obra realizada durante a pesquisa de mestrado de JMB, serviu para fazer, nesta tese, a passagem do artista-professor para o artista-pesquisador, verificando que as palavras-chave "educação" e "pesquisa" estão sendo utilizadas pela arte de agora, dentro de um fenômeno artístico global que tem privilégio de interesse sobre o conhecimento e o pensamento, Você gostaria de participar de uma experiência artística?, de RB, obra exibida na documenta 12, em Kassel, 2007, e tese de doutorado do artista defendida em 2008, entra aqui para mostrar como a pesquisa artística tornou-se uma questão que extravasa os limites da universidade para outros circuitos artísticos, até o momento em que se percebe que a questão da pesquisa, para a arte, não é só uma condição institucional, mas é, antes, parte do projeto poético do artista. Pode-se dizer que a obra de RB é uma obra de pesquisa. Isso porque ela não só está relacionada com a universidade - o artista é um professor e pesquisador universitário, com inúmeros textos importantes para a arte brasileira recente, como sua dissertação publicada em livro, sua tese e outros textos publicados em 
revistas acadêmicas, revistas independentes, ou como capítulos de livros -, mas também porque influi no projeto poético de RB a maior parte dos estados ${ }^{365} \mathrm{da}$ pesquisa artística, tal como vistos no Capítulo 3, da pesquisa do artista na universidade à pesquisa do artista em vários circuitos passando pela pesquisa do artista associada a outros campos, o que demonstra a abertura e a complexidade de seu trabalho, esquematizadas em variadas linhas e camadas poéticas.

A obra de pesquisa Você gostaria...? conecta-se a um projeto poético maior chamado NBP - Novas Bases para a Personalidade e ocorre de forma paralela e imbricada. Forma-se a partir de várias peças e conceitos, uma ideia que conecta todas as obras de RB, "signo verbal/visual" que se apresenta como sigla e como desenho. NBP fala sobre estruturas, projetos, programas, dispositivos e redes, fala sobre o novo que nasce da transformação como também sobre subjetividade e alteridade, o público e as conexões entre os corpos $366 . \mathrm{O}$ artista diz que o significado da sigla:

Claramente orienta-se para uma indagação acerca de estrutura (Bases) e mutabilidade (Novas). (...) A palavra Personalidade vem articular-se às outras duas, procurando conduzir o processo para um lugar que escape a algumas construções cujo sentido tem sido precisado pela filosofia, psicanálise ou literatura (sujeito, subjetividade, interioridade etc.) ${ }^{367}$.

Esta marca, que vai percorrer a maioria dos trabalhos do artista, surgiu entre o final dos anos 1980 e o começo dos 1990, como uma pesquisa que

$365 \mathrm{O}$ trabalho de RB tem ligações sutis com as tecnologias de comunicação e de informação, em tópicos como rede, vírus de grupo, câmeras de segurança, webart, interatividade e participação, daí poderia ser feita uma relação com o estado da pesquisa em arte e tecnologia.

366 Ricardo Basbaum, Projeto NBP. Algumas pistas de um programa em processo, 2006, p. 207. 
avança sobre uma obra anterior chamada OLHO368. Segundo RB, "o projeto 'NBP' surgiu em 1989 (primeiros objetos), firmando-se em 1990 (texto "O que é NBP?"369) e definindo-se em 1991 (forma específica)"370. A forma específica "simples e impregnante" de NBP vai dar origem a objetos, estruturas, desenhos, formatações, mapas, combinadas ou implícitas, em variados usos, materiais, tamanhos e aplicações, de modo que "proposições plásticas e visuais" estejam entrelaçadas "à produção de um campo discursivo" 371 . Vários dispositivos foram sendo criados em torno dessa forma: desenho de grades, disposição de móveis, formato de objetos, diagramas dispostos na parede, projetado nas cidades e nos mapas, aparecendo em vídeos, textos, jogos, oficinas e conversas. O artista diz que acha curioso como reduziu o seu trabalho "a um único desenho, a uma única forma, espécie de retângulo chanfrado com um círculo no centro" 372 . A "forma específica" vai estar conectada com todas as obras, séries e conceitos de RB. A ideia tanto da forma quanto da sigla resultam em um sistema conceitual desenvolvido pelo artista que vai se complexificando conforme as obras vão surgindo e conforme todo o processo de pesquisa artística vai se desenrolando, entrelaçando "texto e imagem, aproximando as dimensões sensorial e conceitual"373. A complexidade desse sistema NBP pode ser verificada, por exemplo, nos diagramas que começam a ser criados a partir de 1993, de forma paralela ao projeto e também como "forma de mapear as implicações produzidas pelas etapas de seu desenvolvimento" 374 , na série Você gostaria...?

368 O projeto OLHO de RB participou da exposição Como vai você, Geração 8o?, realizada na Escola de Artes Visuais do Parque Lage, no Rio de Janeiro, em 1984, onde se desenvolveu como uma marca, aplicada em adesivos que podiam ser colados nas salas de exposição e pelo edifício do Parque Lage. Os adesivos também eram vendidos aos visitantes da exposição. Em 1987, a marca foi aplicada em grande formato em uma torre da Unicamp, quando o artista desenvolvia uma residência nessa universidade, dentro de um evento maior distribuído em várias partes pelos campus, através de várias estratégias e de vários meios.

369 Ricardo Basbaum, O que é NBP?, 1993.

370 Ricardo Basbaum e Cecília Cotrim, Fluindo de diferença para diferença (Entrevista), 2007, pp. 73 e $75-76$.

${ }^{371}$ Ricardo Basbaum, Projeto NBP. Algumas pistas de um programa em processo, 2006, pp. 207-208.

372 Ricardo Basbaum, Renata Marquez et al., Conversa pública com Ricardo Basbaum, 2012, p. 91.

373 Ricardo Basbaum, Você gostaria de participar de uma experiência artística $(+N B P), 2008$, p. 117.

374 Ricardo Basbaum, Projeto NBP. Algumas pistas de um programa em processo, 2006, p. 220. 
ou em outras séries do artista, em diagramas criados e exibidos de forma isolada ou associados com outras obras e séries.

O objeto NBP é um dispositivo que dispara pesquisas específicas, experiências e experimentos realizados por participantes e colaboradores, de forma geral, ou por outros artistas, ao mesmo tempo que é também um dispositivo de investigação de RB. Você gostaria...?, parte de NBP, favorece e apresenta uma imagem da pesquisa, porque, no limite, compõe-se de elementos intelectuais e em proximidade com outros campos do conhecimento: a teoria de artista, o pensamento esquematizado e organizado em diagramas, a colocação de perguntas e problemas como um elo comum entre pesquisa científica e pesquisa artística, a criação de um pensamento coletivo. Um ambiente teórico é instalado com diagramas e textos na obra de arte, que agora se coloca em uma condição simultânea de produção artística e produção do entendimento de seu funcionamento. Segundo RB, em Você gostaria... "estão sendo investigados os limites do campo da arte - ou seja, a presença de gestos, espaços e atividades exteriores à arte tomados em articulação direta com ferramentas e conceitos específicos que envolvem a construção da obra contemporânea" 375 . Essas atividades, que são exteriores à arte, não fornecem uma imagem literal dos outros campos do conhecimento com os quais RB estabelece ligação, embora os diagramas apresentem uma visualidade e um funcionamento que são característicos das Ciências.

Nos e-mails em que JMB convida RB para participar em Projeto Matéria, trocados na época, descobre-se que os artistas começaram a frequentar o Programa de Pós-graduação em Artes Visuais da ECA no mesmo semestre, começo de 2004, o primeiro no mestrado, orientado pela artista Ana Maria Tavares, e o segundo no doutorado, orientado por Martin Grossmann. RB explica no e-mail o que ele pretendia desenvolver: "Meu projeto de doutorado é sobre/a partir daquele objeto NBP que você enterrou/desenterrou... O período do doutorado será aproveitado para reestruturar o projeto e organizar toda a documentação que já tenho...” ${ }^{376}$. Mas o primeiro contato entre os dois

375 Ricardo Basbaum, Você gostaria de participar de uma experiência artística, 2009, p. 62. 
aconteceu antes. RB visitou o ateliê de JMB em 2001 no momento em que RB pesquisava artistas para o $27^{\circ}$ Panorama de Arte Brasileira377. Em 2002, JMB participou do projeto Linha Imaginária 378 e soube por ali do anúncio de inscrição para o Você gostaria...? Daí o artista se inscreveu e recebeu o objeto em seu ateliê na época, um sítio na zona rural de Porto Alegre. Sua ideia então foi enterrá-lo por uma lunação, período em que são vistas as quatro fases da lua. $\mathrm{Na}$ série de fotografias dessa experiência, arquivadas no site do projeto, podemos ver o buraco sendo aberto, o objeto sendo colocado e depois já debaixo da terra. JMB diz que, com isso, ele queria alterar a escala do fluxo do objeto criado por RB, que até então, para ele, se dava com deslocamentos na superfície terrestre. "E no momento em que eu embuti ele dentro da terra é que ele começou a fazer parte de um fluxo que era planetário. Para pensar que o congelamento dele enquanto fluxo da superfície terrestre o coloca em um outro sistema de circulação"379. A abordagem de participação de JMB se dá através de uma visão diagramática, que faz com que pensemos no funcionamento dessa obra de arte não só através de linhas tracejadas sobre o Brasil e o mundo mas também de deslocamentos sobre outros espaços, compartilhando a mesma movimentação de translação e rotação dos corpos celestes.

Antes de JMB, o objeto já tinha sido motivo de outras 26 experiências, segundo podemos constatar no site do projeto380, um grande arquivo da história dessa obra de arte que, a todo momento, sugere um funcionamento complexo com esquematicidade em várias camadas e que demanda uma descrição do

$377 \mathrm{O} 27^{\circ}$ Panorama de Arte Brasileira do Museu de Arte Moderna de São Paulo (MAM), que teve a curadoria conjunta de RB, Paulo Reis e Ricardo Resende, foi a primeira edição do Panorama no século 21, no mesmo ano em que aconteceria o primeiro Fórum Social Mundial em Porto Alegre, e sinalizava uma nova produção artística que pesquisava temas sociais e políticos, com interesse em coletivos, coletividade e comunidades, cotidiano e espaço público, participação, colaboração, cocriação e discursividade. Participaram Artur Barrio, Paulo Bruscky, Carla Zaccagnini, Ducha, Jarbas Lopes, Mônica Nador, Raquel Garbelotti, Rosana Paulino, Rubens Mano, entre outros, e coletivos e espaços independentes como Linha Imaginária, Agora/Capacete, Alpendre e Torreão etc. Ricardo Basbaum et al., Panorama da Arte Brasileira 2001, 2001.

378 O Linha Imaginária foi um projeto de exposições e intercâmbios artísticos nacionais e internacionais realizado entre 1997 e 2010 e coordenado por Sidney Philocreon e Mônica Rubinho. JMB participou do projeto com a obra Minha Terra Sua Terra (MTST).

379 Ver conversa com JMB, no Anexo 3 desta tese.

380 Ricardo Basbaum, Would you like to participate in an artistic experience?, http://www .nbp.pro.br/ 
funcionamento, modo de fazer ou passo a passo da obra em tópicos, em conexão com os conceitos criados por RB. O artista diz, por exemplo, que o papel do objeto físico, um "elemento real e concreto", "é trazer para o primeiro plano certos conjuntos invisíveis de linhas e diagramas, relativos a diversos tipos de relações e dados sensoriais, tornando visíveis redes e estruturas de mediação" 381 . Assim, "os conjuntos de linhas e diagramas, trazidos ao primeiro plano a partir de sua utilização, são mais importantes que o objeto"382. As obras de arte de RB têm funcionamento, e isso fica claro em vários pontos da fala do artista, em entrevistas dadas por ele, nos textos ou artigos em que o artista fala de suas obras, sobretudo em sua tese de doutorado dedicada a Você gostaria... e a NBP, no momento em que um sistema conceitual é criado, ou quando são utilizados tópicos ou conceitos em listas -numeradas, com marcadores, em sequência, em tríades de conceitos e outros tipos de organização teórica ou que vem da pesquisa. Esse funcionamento às vezes é esquematizado pelo artista através do nome "estágios" 383.

Você gostaria...?, outras vezes, é esquematizado por meio de "fases" que se complexificam com a atualização e apresentação do diagrama relacionado a este projeto, como na documenta 12, quando houve uma mudança de escala da obra, em um número maior de objetos dispostos à participação, que impactou seu funcionamento, e assim o projeto rumou para uma nova fase. De 1994, ano do primeiro diagrama, até 2014 foram produzidos cinco diagramas diferentes, ou seja, o projeto encontra-se em sua quinta fase. Os diagramas acabam funcionando também como dispositivos que auxiliam na pesquisa artística de $\mathrm{RB}$, pois eles vão sofrendo alterações conforme os problemas são colocados, em um processo de complexificação que vai aumentando conforme acontecem experiências com a obra. Em muitos momentos, NBP e Você gostaria...? estão de tal forma entrelaçados que não dá para separar o que é do projeto de um e o

381 Você gostaria de participar de uma experiência artística, 2009, p. 61.

382 Ricardo Basbaum, Guia para participantes do projeto "Você gostaria de participar de uma experiência artística?”, 2014.

383 "(1) organização das participações; (2) realização das experiências pelos participantes; (3) disponibilização das novas experiências no website e viabilização da documentação dos participantes do início do projeto; (4) instalação-exposição”. Ricardo Basbaum, Você gostaria de participar de uma experiência artística?, 2007. 
que é de outro, sobretudo por conta da visibilidade e da complexidade que o último obteve, ou pelo fato de que a tese de doutorado de RB é também sobre NBP. Essa confusão se desfaz em muitos momentos na trajetória do artista, e pode ser vista no próprio diagrama, embaixo do desenho do famoso objeto que dispara as experiências de Você gostaria...?, onde está escrito "projeto NBP Novas Bases para a Personalidade". Assim, o diagrama que vem sendo alterado no tempo é um mapa que conta a história das fases de ambos os projetos, cuja “continuidade, através dos anos, só se fez possível na medida em que se transforma[m] e busca[m] sempre novas possibilidades; logo, um histórico de seu[s] percurso[s] indicará uma sequência de transformações" 384 . No diagrama encontram-se espacializadas algumas marcações - que podem ser, ao mesmo tempo, conceitos, obras e séries, frases ou nomes de textos de RB -, como "nbp $\mathrm{x}$ eu você", "jogos eu-você", "transatravessamento", "superpronome", "membranosa", "conjs.", "re-", "obs.", "sistema-cinema”, "conversas-coletivas", "pergunta dentro de pergunta". Também são marcados: "ensaio-ficção", "romance-crítico", "dinâmica de grupo", "pedagogia das vanguardas”, "museu dentro do museu", "deslocamentos rítmicos", "trauma”, "artista-etc", conceitos que RB constrói para dar conta de sua própria obra e que, em muitos casos, poderiam ser usados para ler obras feitas por outros artistas de agora. Também são encontrados no diagrama palavras e expressões como experiência, transformação, espectador, participante, imagem. É um diagrama complexo, cheio de camadas, que faz conexões entre séries, textos, obras de arte e conceitos, e pode ser considerado um mapa do projeto poético de RB.

O funcionamento complexo, a esquematicidade em várias camadas, as linhas e os diagramas, o sistema conceitual, os conceitos espacializados ou em listas e tríades de conceitos, os estágios, as fases são recursos para lidar com a obra no tempo, já que se trata de um "trabalho em curso" - a expressão aparece na tradução de 2005 realizada por JMB do texto de RB "Differences Between Us and Them", publicado primeiramente em inglês. No texto original foi utilizada a palavra "work-in-progress", mas o uso da expressão "trabalho em curso" seguiu

384 Ricardo Basbaum e Cecília Cotrim, Fluindo de diferença para diferença (Entrevista), 2007, p. 73 . 
a denominação "travail-en-cours" utilizada pela artista argentina Alejandra Ariera: "Trata-se de uma atualização do termo, mantendo a noção de um caráter contínuo da investigação artística, eliminando porém a noção de progresso, demasiadamente comprometida com a linearidade historicista e desenvolvimentista do modernismo" 385 .

O funcionamento pode aparecer também como instrução para o participante, como no texto do "Guia para participantes" de Você gostaria...?, nomeado por RB como "conjunto de protocolos indicativos"386. E, ainda, esse funcionamento aparece de forma muito complexa na tese de doutorado que o artista dedicou a essa obra, em que são feitas explicações, descrições e teorias a partir de oito "blocos de agregados conceituais". O artista diz que se tornou evidente que a maneira como ele problematizaria a pesquisa de doutorado seria a partir do próprio diagrama que vem sendo desenvolvido paralelo ao percurso de Você gostaria...?, onde foram destacados esses blocos, que são áreas tanto no diagrama quanto na tese, que funcionam, segundo o artista, como uma espécie de hipertexto, em um entrelaçamento entre diagrama e discurso, teoria de artista composta "de narrativas teórico-poéticas, através da utilização de escrita que inclua colagem e invenção"387. As oito "áreas de interesse”, encontradas dentro do diagrama, constituem uma "prospectiva de mapa-programa em aberto" 388 , programa mais amplo em que texto e obra se confundem, partindo de um interesse do artista em trabalhar "na construção de um sistema conceitual (...) ou da possibilidade de trabalhar com o discurso e a derivação desse discurso", também uma "vontade de trabalhar com um projeto, ou seja, de ter uma perspectiva de longo prazo"389, onde conceitos, objetos, estruturas, fluxos, conversas, todas essas peças têm a mesma importância em um plano. Não se pretende aqui fazer uma explicação que aumente a teoria de artista já

385 Ricardo Basbaum, Diferenças entre nós e eles, 2005. (Tradução do original em inglês por Jorge Menna Barreto.)

386 Ricardo Basbaum, Guia para participantes do projeto "Você gostaria de participar de uma experiência artística?”, 2014.

387 Ricardo Basbaum, Você gostaria de participar de uma experiência artística (+NBP), 2008, p. 74-79.

388 Ricardo Basbaum, Você gostaria de participar de uma experiência artística (+NBP), 2008, pp. 74-79. 
instituída por RB, parte de sua tese e dos diagramas associados a Você gostaria...? ou ao projeto mais geral de NBP, uma vez que o objetivo deste capítulo é tentar entender o funcionamento desses elementos e peças conceitos, dispositivos, objetos, pensamentos, conversas, diagramas etc. - sobre o plano da pesquisa artística.

\section{Funcionamento e exibição}

Um objeto é oferecido por RB à participação de pessoas ou grupos, artistas ou não, que são desafiados a realizar uma experiência artística a partir de um uso específico desse objeto específico. No "Guia para participantes" fica clara a liberdade que é dada ao participante, onde se lê que o objeto "pode ser usado de diferentes modos e você pode fazer qualquer coisa com ele: use-o como quiser, da maneira que achar melhor" 390 .

O objeto tem uma "forma específica": é octogonal, tem um furo no meio e “oferece área interna a ser preenchida - tal qual um contêiner" 391 ou uma forma de bolo. Segundo RB, o projeto foi se formalizando "tentando perceber a circulação desse objeto, como objeto doméstico que pudesse ser levado para casa e depois retirado" 392 . É um objeto grande, medindo 1,25 x 0,80 x 0,18 m, feito de aço esmaltado por processos industriais, todo branco mas com as bordas em azul-marinho. A chapa, depois de assumir a sua forma por pressão, é mergulhada em esmalte líquido e queimada em forno. A borda é pintada à mão. Assemelha-se a um objeto de uso doméstico, um utensílio. O material, comumente chamado de ágata no Brasil, é utilizado em pratos, canecas, penicos e banheiras antigas. O design clássico branco e azul é atribuído a Falcon Enamelware393, uma indústria britânica de utensílios de ágata que existe desde 1920. O artista diz que esta foi a sua inspiração: "Eu já havia feito uma peça em fórmica, uma peça em napa e espuma, uma peça em ferro. (...) Eu estava

390 Ricardo Basbaum, Guia para participantes do projeto "Você gostaria de participar de uma experiência artística?”, 2014.

${ }^{391}$ Ricardo Basbaum, Você gostaria de participar de uma experiência artística $(+N B P), 2008$, p. 87.

392 Ricardo Basbaum e Marina Fraga, Carbono Entrevista Ricardo Basbaum, 2013.

393 Falcon, Our Story, https://www.falconenamelware.com/pages/our-story. 
passando um período em Londres, com uma bolsa de estudos, e acabei fazendo essa nova peça na linha de objetos domésticos que você encontra por lá (...)394.

A conexão entre RB com o interessado pode se dar por inscrição, mas também por convite, com indicação de amigos ou instituições que estiverem abrigando o projeto, em determinado momento e em em diferentes partes do mundo. Segundo o artista, no começo havia um esforço da parte dele para que esses contatos se dessem. "Agora me encontro na situação interessante de conhecer pessoas através do objeto, o que é muito prazeroso em termos de acesso a outras pessoas e circuitos." $395 \mathrm{Na}$ documenta 12, a distribuição foi orientada por um setor da organização da mostra. Em outros momentos há uma apresentação pública, dependendo do contexto em que o projeto está inserido, como uma palestra feita por RB para disparar os contatos de participação.

Depois disso, o objeto é enviado, dentro de uma logística muito variável. No começo, havia uma movimentação menor e o artista geralmente pagava pelo transporte. O artista fala que talvez o objeto "tenha ido do Rio pra Vitória de caminhão (...). Aí ele volta para o Rio, depois foi pra Brasília. Quando ele foi pra Brasília eu lembro de ir no aeroporto botar em um avião" 396 . Então, o artista percebe que, a partir de determinado momento, as pessoas foram se organizando por si próprias para receber o objeto, sendo que no começo só existia um. De Brasília para Goiânia e de lá para Belo Horizonte; depois para Porto Alegre, Florianópolis e assim por diante. Por isso RB diz que o projeto passa para uma segunda fase, gerando um novo diagrama, já que o objeto começa a circular em uma rede, em um sistema. Depois, dentro do processo institucionalizado da documenta 12, houve dinheiro não só para o transporte dos objetos, via FedEx, como para a construção de mais novos objetos. A partir daí, todo o processo de envio acaba sendo, na maioria das vezes, custeado também pelas instituições que se interessam em recebê-lo, parte de uma exposição ou de um evento.

Há uma quantidade de objetos que circula: até hoje foram produzidos aproximadamente trinta objetos. Entre 1994 e 2005 um único objeto circulou.

394 Ricardo Basbaum e Marina Fraga, Carbono Entrevista Ricardo Basbaum, 2013.

395 Ricardo Basbaum, Diferenças entre nós e eles, 2005.

396 Entrevista concedida por RB, localizada no Anexo 2 desta tese. 
Segundo o artista, isso "se deveu apenas a fatores econômicos"397, já que ele é múltiplo e de tiragem aberta, "não há diferença entre primeira, segunda e terceira, todas são rigorosamente iguais" 398 . Com a documenta 12 foram fabricados dez objetos em Kassel e dez em Florianópolis, e foram distribuídos assim: seis em Kassel, um em Liverpool, um em Viena, um em Dakar, um em Liubliana na Eslovênia, um em Buenos Aires, um em Valparaíso no Chile, um na Cidade do México, um em Rio Branco, um em São Paulo, um no Rio de Janeiro, um em Curitiba e dois em Florianópolis.399

As pessoas e os grupos começam a participar, resultando em variados tipos de usos e atividades ${ }^{400}$. O objeto fica um mês, aproximadamente, com o participante. A ideia é que seja passado adiante, que circule. Algumas experiências acontecem nas casas das pessoas, em ambiente íntimo e particular. Outras ocorrem entre amigos ou no espaço público. Alguns usos são cotidianos, como atribuir sentido no ambiente familiar como mesa, cama, armário, banheira, reservatório de água, bebedouro para animais, aquário, forma de bolo. Outras experiências assumem a linguagem e a pesquisa artística do artista que está participando, dando origem a outros objetos de arte ou usos performáticos. Algumas propostas expuseram o limite do sentido da circulação do objeto e até o desacordo do artista em relação a elas. O objeto já foi clonado e passado adiante, sendo o original destruído pelos participantes. Em outra experiência, o objeto foi doado a um museu, mas RB resgatou-o de volta à circulação401.

$\mathrm{RB}$ confere a responsabilidade sobre a experiência artística às pessoas que estiverem de posse do objeto, que devem cuidar para que uma escolha aconteça, uma atividade seja feita e que haja registro. Ou seja, ao artista cabe articular e gerenciar o projeto. Segundo RB, o artista não desaparece mas torna-

\footnotetext{
397 Ricardo Basbaum e Soraia Vilela, Você gostaria de participar de uma experiência artística? (Entrevista), 2007.

398 Ricardo Basbaum e Marina Fraga, Carbono Entrevista Ricardo Basbaum, 2013.

399 Ricardo Basbaum, Só funciona nessa responsabilização do outro por uma ação não idealizada (Entrevista), 2013, p. 18.

400 Ver mais sobre as participações que aconteceram a partir de Você gostaria...?, por exemplo, em: Ricardo Basbaum, Ana Kiffer e Renato Rezende, Ricardo Basbaum (Entrevista), 2013; Ricardo Basbaum, Só funciona nessa responsabilização do outro por uma ação não idealizada (Entrevista), 2013; Guy Brett, Ricardo Basbaum. Arte no plural, 2009; Graziela Kunsch, R. x eu, 2007; Pablo Lafuente, Ricardo Basbaum, Or That Elusive Object of Emancipation, 2011.

${ }^{401}$ Ricardo Basbaum, Relatório de uma visita ao MASC no dia 13 de junho de 2005.
} 


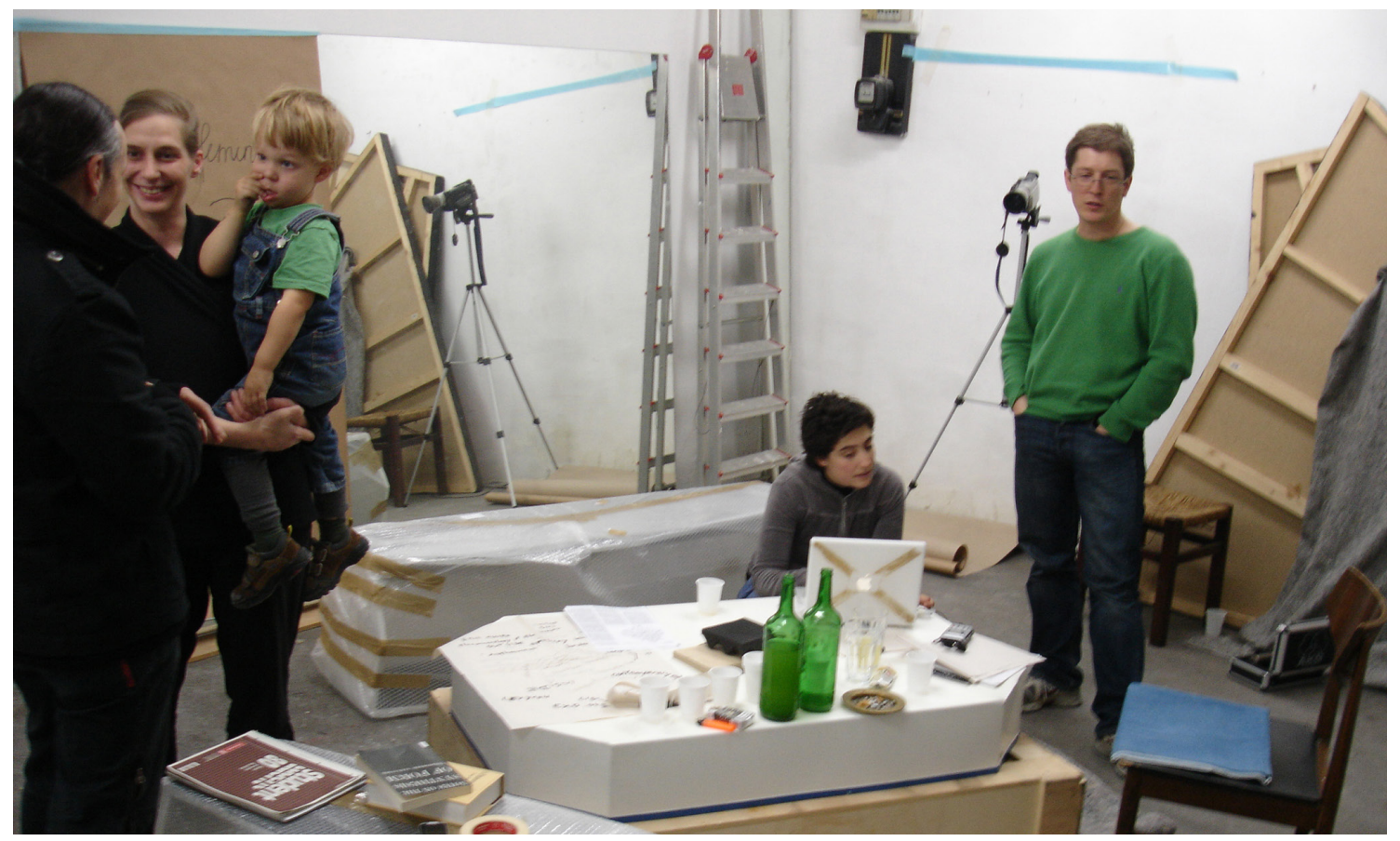

Ricardo Basbaum, Você gostaria de participar de uma experiência artística?, trabalho em progresso desde 1994. Em sentido horário, as participações de: FO/GO lab, Vienna, Austria, 2006; Dance Physics, Bruce Nockles, Ricardo Basbaum, [small operatic event], The Showroom Londres, UK, 2010; Éverton Almeida e Roberta Benevit, Palhoça, 2007; Casa das Artes da Mangueira, Rio de Janeiro, 2006.

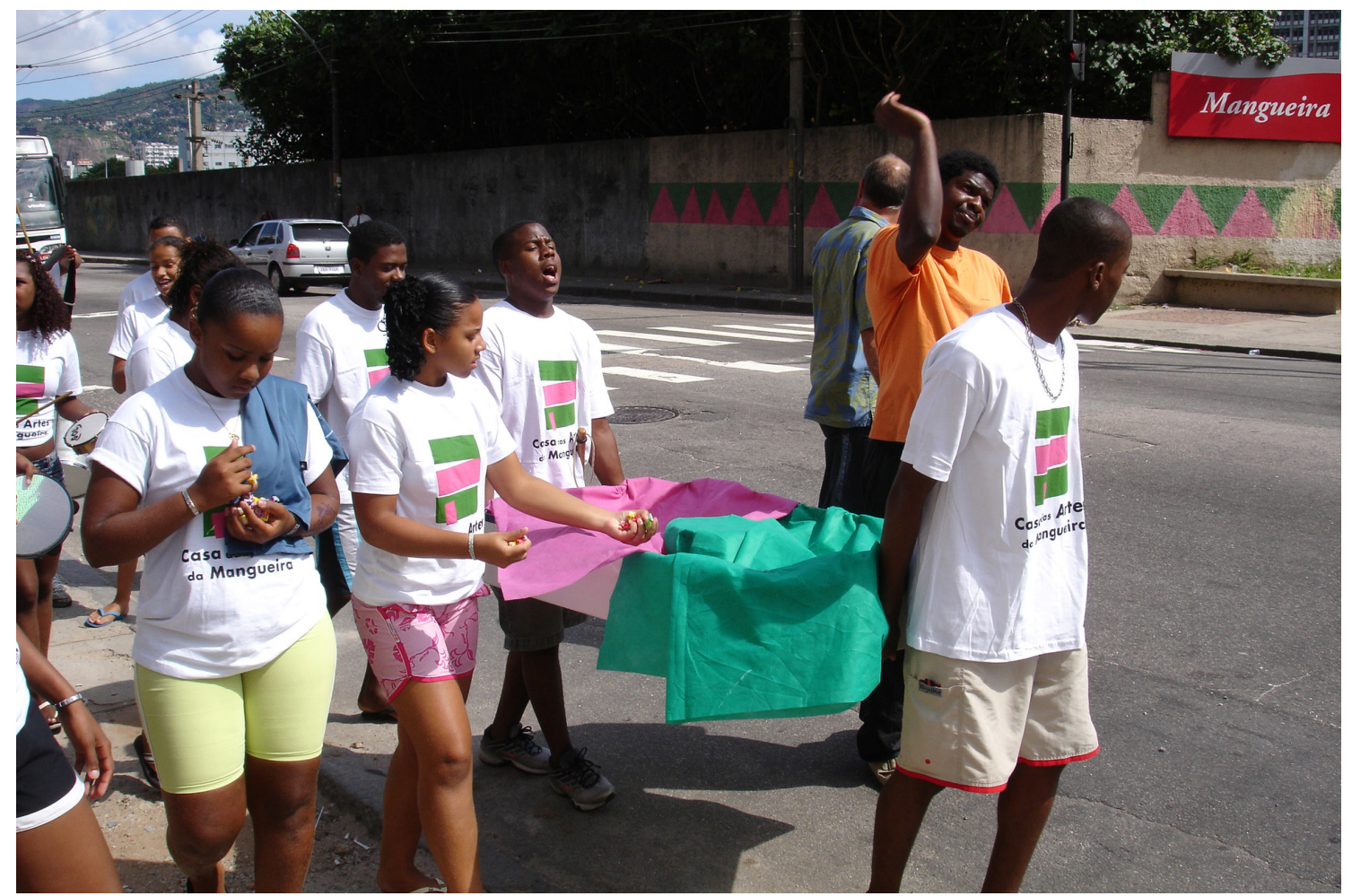



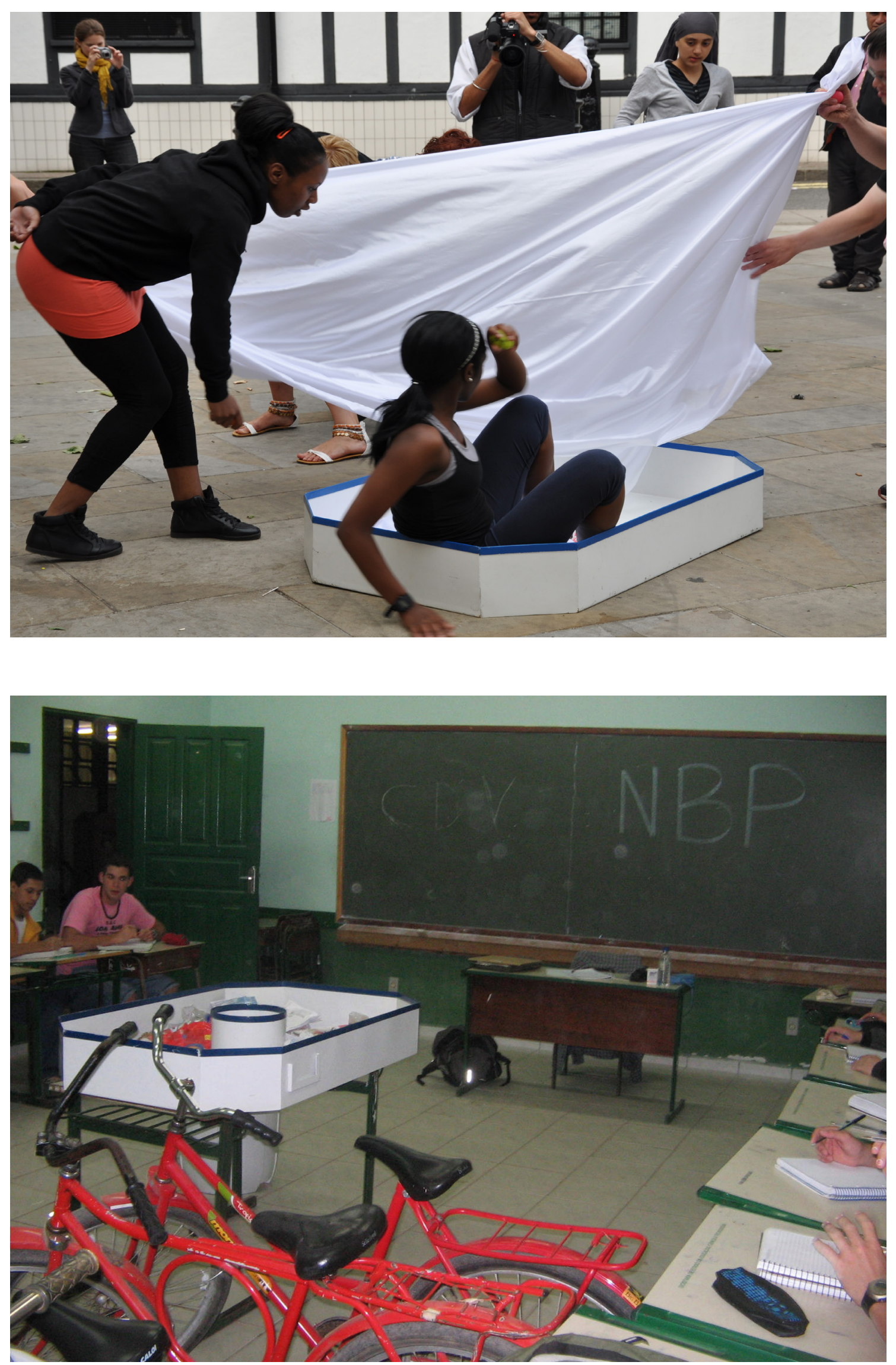
se um "administrador dos processos propostos, atuando a favor da construção e organização de algumas leituras possíveis e de sua publicação" 402 .

Uma das responsabilidades do participante é registrar a utilização do objeto, é produzir e postar uma documentação. Documenta-se a obra no site www.nbp.pro.br, que existe desde 2006, criado para a documenta de Kassel, e ajuda-se a automatizar esse processo de participação. Antes disso as negociações aconteciam com uma mediação maior do artista, em contato direto com as pessoas. No começo do projeto, que é anterior à popularização da internet, as respostas vinham sobretudo por correio, o que ajudava a elaboração de outros tipos de entregas, não só fotografias, mas incluía a elaboração e o envio de objetos artísticos feitos pelos participantes. É disponibilizada ao participante uma área logada no site com ferramentas para envio ou edição dos resultados de sua participação como textos, imagens, sons, vídeos. O site, segundo artista, é um banco de dados onde se pode ver a história de participações 403 .

Há o momento da experiência do participante e o momento da exibição da obra em uma exposição de arte. O objeto não foi feito para ser uma peça de museu, e o modo como o projeto é pensado dispensa galerias e museus para poder funcionar. "Além disso, o site do projeto já é uma estrutura de exibição"404, diz o artista. Mesmo assim, RB cria estratégias de exibição em bienais, museus, galerias ou centros culturais, com o uso de estruturas e dispositivos, além de colocar o objeto à participação. As estruturas arquitetônico-escultóricas contêm um compartimento embaixo das camas, no modelo das estruturas metálicas de RB, feito para guardar o objeto enquanto ele está fora do museu para experiências. $\mathrm{Na}$ exposição individual conjs., rebancos*: exercícios\&conversas que aconteceu em Belo Horizonte em 2012, um computador foi disponibilizado para o acesso ao site do projeto. Além disso um objeto que estava no Acre foi resgatado e logo colocado em uso. O projeto

402 Ricardo Basbaum, Você gostaria de participar de uma experiência artística, 2009, p. 60.

403 Ricardo Basbaum e Cecília Cotrim, Fluindo de diferença para diferença (Entrevista), 2007, p. 73.

404 Ricardo Basbaum e Modesta Di Paola, Entrevista com Ricardo Basbaum, 2010. (Tradução do autor.) 
começou a ser visto com mais regularidade, tanto no Brasil quanto no exterior, a partir da documenta 12, que teve a curadoria de Roger Buergel. Primeira tentativa de exibição dos resultados e da documentação gerada pelos participantes, a estrutura da obra, chamada por RB de estrutura arquitetônicoescultórica, estava presente no chamado Aue-Pavillon, um grande pavilhão temporário construído especificamente para a mostra daquele ano e localizado no gramado de frente à Orangerie, em Kassel. RB utilizou dispositivos, estruturas e módulos com que já vinha trabalhando, feitos de grades metálicas. A instalação foi composta de bancos, camas, corredores, passagens, com colchonetes e almofadas, e arquibancada voltada para a exposição. Monitores e computadores exibiam vídeos e fotografias em slideshow das experiências e o site do projeto como um grande arquivo. O diagrama era exibido em uma parede na parte externa da obra. Câmeras de vigilância filmavam o espaço da instalação, monitorando e gravando a vivência e participação do público da mostra dentro da estrutura, e essas imagens eram também exibidas em monitores. Segundo RB, a instalação funciona como uma membrana entre o projeto e a documenta 12, apresenta-se, deste modo, como “(...) uma estrutura arquitetônico-escultórica que se abre para a experiência sensível e propõe um espaço para ser assimilado como vivência"405. O artista pensa, desse modo, em estratégias de exibição para a compreensão de seu trabalho no contexto de uma mostra de grandes dimensões, que se dá com a criação de um lugar complexo de exibição e convívio, recurso utilizado por ele em outros momentos, criando o que ele chama de "museu dentro do museu" ou "arquitetura dentro da arquitetura", um lugar autônomo dentro da própria mostra. Estratégia conceitual que, segundo o artista, busca proteger a autonomia da obra, negociando sua presença dentro do evento406. Modos parecidos de exibição em escala menor foram vistos depois nas exposições coletivas Quase Líquido realizada no Itaú Cultural em 2008; A Rua (De Straat), que teve a curadoria de Dieter Roelstrate, ocorrida no Museu de Arte Contemporânea de Antuérpia

405 Ricardo Basbaum e Daniel Reyes León, Entrevista a Ricardo Basbaum, 2007. (Tradução do autor.)

406 Ricardo Basbaum e Daniel Reyes León, Entrevista a Ricardo Basbaum, 2007. (Tradução do autor.) 
(MHKA) em 2011; e Aberto Fechado: Caixa e Livro na Arte Brasileira, que aconteceu na Pinacoteca do Estado de São Paulo em 2012, com curadoria de Guy Brett. Outros exemplos de exibição e funcionamento do objeto correram, por exemplo, na $7^{\text {a }}$ Bienal do Mercosul, 2009, dentro do programa misto de curadoria educativa e residência artística chamado "artistas em disponibilidade"; relacionando-se com a tese de RB na exposição e simpósio sobre pesquisa artística chamado Nameless Science, que ocorreu no espaço apexart, de Nova York, organizado por Henk Slager em 2009; como participação e exibição de estrutura na mostra coletiva $A$ Singular Form, na Secession de Viena, em 2014, com curadoria de Pablo Lafuente; e como conversas na exposição El Contrato, parceria entre os espaços Bulegoa z/b e Azkuna Zentroa de Bilbao em 2014.

\section{Pesquisa artística em curso}

Você gostaria...? teve início em 1994, quando RB fazia um Master in Fine Art (MFA) na Goldsmiths, Universidade de Londres, e ainda está em curso. "Sua continuidade, através dos anos, só se fez possível na medida em que se transforma e busca sempre novas possibilidades; logo, um histórico de seu percurso indicará uma sequência de transformações"407, diz o artista.

Por essa época, o artista construiu o objeto e riscou o primeiro diagrama do projeto. O artista diz que foi na volta do Reino Unido "já tendo descoberto a questão do diagrama", que resolveu o problema que o levou ao mestrado: o "conflito entre a questão da escrita e o trabalho", sendo que o projeto NBP, segundo ele, "é exatamente sobre isso" 408 . A pesquisa de RB toma um caminho muito peculiar em direção à pesquisa e à teoria, independente do tipo de pesquisa artística que era feita nos programas que passou: "A minha ida à Inglaterra foi muito importante. $\mathrm{E}$, ao mesmo tempo que tive esse amadurecimento, tive também um conflito com o próprio curso" ${ }^{409}$. Ainda que

\footnotetext{
407 Ricardo Basbaum e Cecília Cotrim, Fluindo de diferença para diferença (Entrevista), 2007, p. 73 .

408 Entrevista concedida por RB, localizada no Anexo 2 desta tese.

409 Ricardo Basbaum, Ricardo Basbaum (Relato), 2008, p. 116.
} 
um mestrado em Arte tenha uma característica diferente do doutorado em Arte, principalmente no Reino Unido, RB adverte para a característica reflexiva de sua obra e de sua pesquisa: "Eu já me sentia maduro e já me sentia pesquisando algo que tinha a ver com o meu trabalho. Eu achei que a tônica do curso não era ver o trabalho do jovem ali dentro como pesquisa, mas como um espaço de produção e de ateliê" 410 .

De volta ao Brasil, RB fez o objeto circular pelo Brasil, começando no Espírito Santo, em conexões que se deram com a participação do artista no Festival de Arte de Nova Almeida411. Na edição de 1993, ele apresentou o projeto NBP e deu o curso "Propaganda da arte: conversas". Em 1995 expôs Projeto $N B P+4$ manifestos, e desenvolveu o curso "Objeto + conceito" ${ }^{12}$. Essas relações resultaram nas participações do coletivo SIM ou ZERO413, e também de Marcia Prezotti e depois de Mara Perpétua, ocorridas entre 1994 e 1996. Segundo a periodização de RB, o projeto encontra-se na fase 5. A fase 1 ocorreu de 1994 a 2000. Segundo o artista, essa fase inicial foi de "construção de interesse" para que começasse a acontecer uma circulação414. A fase 2 aconteceu de 2000 a 2004; a fase 3, de 2004 a 2008; a fase 4, de 2008 a 2014. E a fase 5 vem acontecendo desde 2014. A cada fase há uma atualização do diagrama, que atualmente é bastante complexo. A ideia de demarcação serve para lidar com o trabalho em curso, uma obra que dura no tempo, em que o artista gerencia os desdobramentos do trabalho e faz uma análise dos resultados, principalmente através de elaboração de conceitos e diagramas. Depois de Kassel, por exemplo, houve uma mudança de escala que impactou o funcionamento da obra. RB adicionou mais uma etapa ou peça, que é o website, que funciona tanto como um catalizador das participações quanto um arquivo.

Podemos fazer um paralelo do "trabalho em curso", de Você gostaria...? ou de todas as obras de RB que giram em torno de NBP, com o percurso e o

410 Entrevista concedida por RB, localizada no Anexo 2 desta tese.

${ }^{411}$ Ricardo Basbaum e Edison do Carmo Arcanjo. Os Festivais de Verão em Nova Almeida e o Projeto "Você Gostaria de Participar de uma Experiência Artística?", 2014.

412 Edison do Carmo Arcanjo, Amarelinho, 2013.

413 Coletivo formado na época por Alexandre Antunes, Edmilson Vasconcelos, Renato Coelho e Wagner Vasconcelos.

414 Ricardo Basbaum e Marina Fraga, Carbono Entrevista Ricardo Basbaum, 2013. 
significado amplo da ideia de pesquisa artística, pois esta não passa necessariamente somente pela pesquisa artística na universidade nem tem, necessariamente, um caminho institucional coerente. A complexa pesquisa artística de RB apresenta-se como um desvio, por não fazer um percurso retilíneo sobre os programas de pesquisa em arte ou por RB nunca ter sido um pesquisador que obteve uma constância de auxílios para pesquisa. Em entrevista para esta tese, RB diz: "Eu fui me constituindo como artista, realmente, aproveitando o espaço da universidade para construir o meu processo de trabalho, embora, paradoxalmente, nada disso você vai encontrar registrado em projetos encaminhados para as agências de fomento"415. Também é emblemático, nesse sentido de desvio da pesquisa artística, RB ter começado no departamento de História da Arte do Instituto de Artes da UERJ, ou seja, ele não estava inserido no lugar até então próprio para a pesquisa do artista na universidade, como "Poéticas Visuais" ou "Linguagens Visuais".

RB diz que desde muito jovem buscou uma relação com a universidade. Por volta de 1985, ele fez seu ingresso no curso de especialização da PUC-Rio416, um curso criado pelo artista Carlos Zilio. O artista diz que intuiu, pelo tipo de trabalho que desenvolvia, que seria muito difícil viver do mercado da arte, ainda mais nos anos 1980, porque ele "não estava naquele enclave de artistas que buscaram uma relação direta com o mercado, atendendo a uma demanda" 417. Dar aula de Artes era uma coisa que lhe interessava e poderia ser uma maneira de sobreviver como artista.

Hoje eu vejo que o meu trabalho também é sobre isso, sobre como a gente se inventa como artista num local qualquer, no meu caso em um local e um contexto específico que é o Brasil da abertura política dos anos 1980, início do neoliberalismo, enfim, o contexto de onde eu vim ${ }^{418}$.

\footnotetext{
415 Entrevista concedida por RB, localizada no Anexo 2 desta tese.

${ }_{416} \mathrm{RB}$ escreveu um texto sobre a arte dos anos 1980 como monografia para a sua especialização.

417 Entrevista concedida por RB, localizada no Anexo 2 desta tese.

${ }^{418}$ Entrevista concedida por RB, localizada no Anexo 2 desta tese.
} 
No começo dos anos 1990 o artista diz que tentou cursar um mestrado nas "Poéticas Visuais" da USP e no Multimeios da Unicamp - dois lugares pioneiros de programas próprios para o artista na universidade brasileira, tal como foi visto anteriormente -, mas acabou não sendo aceito em nenhum desses dois. Daí que o artista resolveu ficar no Rio mesmo, que já era o lugar de sua residência, e buscou uma aproximação com a ECO, a Escola de Comunicação da UFRJ, onde ingressou como mestrando em 1992. Durante o curso, entre 1993 e 1994, teve a experiência no Master in Fine Art, em Londres. Segundo o artista, a ECO era um lugar, na época, que um grupo de pesquisadores e professores estavam voltados para o pensamento contemporâneo. Ele diz que foi bem acolhido ali e que fez, por essa época, um texto que dialogava com seu processo artístico intitulado "Migração das palavras para a imagem”, que depois virou um capítulo de sua dissertação, hoje reproduzida no livro Além da pureza visual. RB também já percebia naquele momento que possuía um interesse não só pela aula mas também pela escrita, como lugar de expansão da prática do artista, para funções próximas do escritor, do pesquisador, do crítico. O artista diz que não queria representar esses papéis, mas se via antes como um artista que busca utilizar essas ferramentas419. Nessa época, RB foi protagonista de algumas ações artísticas que ajudaram a reafirmar essa imagem do artista que assume outros papéis e funções, inclusive a de artista-pesquisador, que culminará na ideia de artista-etc. Entre 1989 e 1994, ele fez parte de um grupo no Rio de Janeiro, chamado Visorama420, que começou como grupo de estudos, mas se tornou algo muito próximo do que hoje é entendido como um coletivo de artistas, promovendo ciclos de palestras em várias cidades. Pouco depois, ele será um dos editores da revista item, com os artistas Eduardo Coimbra e Raul Mourão, que teve seis edições entre 1995 e 2003. Entre 1999 e 2002, RB ajudou a manter o Espaço Agora/ Capacete, uma colaboração entre a agência Agora - Agência de Organismos Artísticos, mantida por ele e outros dois artistas-editores da revista item - e o Capacete 
Entretenimentos, de Helmut Batista. RB diz que, para seus participantes, Visorama "significou uma tomada de posição em relação ao circuito, investindo numa imagem do artista preocupado não apenas com os rumos de sua produção num ultrarrestrito mercado de arte, mas também com as conversas e comentários críticos que suas intervenções poderiam suscitar" ${ }^{21}$. A revista item, nesse sentido, foi para ele, "um passo além do Visorama, no sentido de poder fomentar o desenvolvimento de questões, proposições e ideias que trabalhassem em ressonância com nossa produção plástica" ${ }^{222}$. Proposições, ideias e produções que foram trabalhadas "sob o signo da transdisciplinaridade (cruzamento e superposição de vários campos do conhecimento) e Intermídia (livre trânsito entre diferentes meios de expressão, com a utilização de diversos materiais)" 423 . Essas ações transdisciplinares culminaram no estabelecimento da agência Agora e do espaço Agora/ Capacete, como lugares de promoção da produção, exibição, pesquisa e discussão artística. A pesquisa do artista e suas qualidades teóricas e de pensamento coletivo nunca estiveram restritas ao ambiente universitário. Esses ambientes de pesquisa acabam sendo deslocados para grupos, espaços e revistas independentes, que se utilizam de outros circuitos ou os criam, e essas atividades de pesquisa e reflexão são parte importante da trajetória e do projeto poético de RB.

A posição de RB sobre a pesquisa do artista em vários circuitos é a de uma pesquisa que tem em consideração a política da arte contra o preestabelecido do mercado de arte - que "corta muitas possibilidades e poéticas que não se adequam ao seu jogo"424. Por isso, RB considera também um possível e outro "mercado de arte", fora do circuito em torno das galerias e feiras, uma infinidade de atividades para as quais o artista acaba sendo pago, como organizar cursos e palestras, escrever e publicar livros e textos, percebendo o artista inserido dentro de uma produção cultural mais diversificada: "É parte do mercado de atuação do artista a realização de um seminário, uma palestra, a construção da escrita, junto à produção de uma obra

\footnotetext{
421 Ricardo Basbaum, E Agora?, 2002, p. 85.

422 Ricardo Basbaum, E Agora?, 2002, p. 88.

423 Revista item, 1995.

424 Ricardo Basbaum e Felipe Scovino, Ricardo Basbaum (Entrevista), 2009, p. 74.
} 
que pode ser vendável; ações educativas, por exemplo"425. O artista diz que construiu sua carreira procurando a todo momento modos de atuação que não fossem necessariamente atrelados a compra e venda de obras de arte, em um percurso de investigação e construção sobre o lugar em que ele, como artista, deveria ocupar. "É interessante que se perceba o artista para além do mero produtor de obras de arte" 426 , como alguém que também produz o lugar de produção da arte, como também o lugar do artista, ou seja, cria outros circuitos para a sua atuação, que podem ser independentes dos circuitos e das instituições tradicionais da arte. Dessa maneira, a universidade é hoje um lugar importante produzido pelo artista, para que ele possa trabalhar com liberdade reflexiva e de criação. Para RB, e para muitos outros artistas, a universidade é um lugar privilegiado onde a arte pode ser pensada e produzida. RB diz que, nos últimos tempos, "a universidade também passou a ser problematizada" por ele como um lugar que pode ser produtivo para a atuação do artista. $\mathrm{O}$ artista sempre pontua e está alerta para o fato de que o meio acadêmico tem modos próprios de legitimação, e não apresenta uma facilidade de mistura com o "mundo da arte". Levar um projeto artístico para dentro da universidade requer um trabalho de pensar estratégias para deixar as barreiras entre esses territórios menos rígidas, para que possa haver uma conversa mais dinâmica e produtiva. Assim, o artista pode trazer "o circuito para dentro da universidade" e levar "a universidade para fora", de um modo que ele não fique "preso em nenhum desses mundos" 427 .

A universidade pode ser entendida, mesmo com todos os seus protocolos e institucionalidades, como um lugar de "descanso" reflexivo - ou, nas palavras de JMB, "recuo crítico" - e um lugar onde o artista e a arte podem sobreviver (financeira mas também intelectualmente) não necessariamente atrelados ao mercado muito restrito, em direção a um pensamento coletivo e de troca de conhecimento. $\mathrm{E}$ isso pode ser verificado na situação brasileira atual, da pesquisa artística que está bem desenvolvida e espalhada por vários programas de pós-graduação pelo país. A pesquisa do artista que poderia ser realizada fora

425 Ricardo Basbaum, Mediações, 2014, p. 32.

426 Ricardo Basbaum, Mediações, 2014, pp. 32-33.

427 Ricardo Basbaum, Would you like to participate in an artistic experience?, 2009. 
da universidade acaba encontrando uma receptividade e um respaldo ali dentro, nesse lugar de "descanso", criando outra institucionalidade e outro circuito, em uma esperada conexão com outros lugares da arte como espaços, grupos e revistas independentes, por exemplo. E também porque não com o "mercado da arte”, centros culturais, museus. Uma vez que a todo momento RB está no embate entre pesquisa artística produzida dentro e fora da academia, a problematização também adentra a poética da obra de arte, em um questionamento sobre a diferença entre o lugar da arte e a própria obra de arte. Qual a diferença do escrito, teoria e livro de artista dentro ou fora da universidade? Assim como qual a diferença entre a aula ou a oficina que o artista ministra dentro da universidade daquela aula ou oficina que o artista diz ser parte integrante de sua obra de arte? Essas fronteiras não são respeitadas por RB, que não está interessado em se comprometer com apenas um lugar ou circuito. O artista aproveita-se dessa multiplicidade de lugares em que a pesquisa artística pode acontecer, pressupondo que cada artista é um pesquisador, cada um com sua trajetória, projeto poético e questionamentos próprios.

Eu acho que uma parte dos que formalizam a questão da pesquisa em artes não veem no meu trabalho pesquisa, porque eu não adentro o território plenamente, dos protocolos necessários para que aquilo seja identificável, mas eu vejo que essas questões estão na prática do meu trabalho, mais do que em outros artistas, porque o meu trabalho investe na produção de pensamento e porque ele reconhece, na sua metodologia, um passo anterior à formalização disso na aula, ou no que seja428.

A história "irregular" sobre a pesquisa artística na universidade abre-se para uma pesquisa artística consistente através dos circuitos já existentes e também dos que são criados pelos próprios artistas, assim como o circuito 
aberto dentro da própria universidade como um desvio e como uma maneira de sobreviver na adversidade artística (não só brasileira), do reducionismo da arte orientada apenas ao mercado. $\mathrm{O}$ artista não vai dar aulas ou pesquisar só por uma questão de necessidade de sobrevivência financeira, mas antes por perceber que o sistema da arte, tal como é configurado, não oferece muitas condições para a experimentação livre do artista, do artista interessado em um tipo de arte que não passa necessariamente pela venda. Além disso, são produções que se orientam pelo coletivo, participação, amizade429, convívio, público, entorno, comunidade, com acento político e ênfase crítica430. O tipo de arte feita por RB não se prende necessariamente a objetos e, em certos momentos, é contra qualquer tipo de cooptação ingênua desses objetos pelo mercado ou mesmo pelas instituições galeria de arte, museu, grandes exposições. RB representa, no contexto brasileiro, o artista preocupado com a reflexão e a criação de lugares para que essa reflexão seja feita, um grupo de pesquisas, uma revista, um coletivo, um espaço independente de pesquisas gerenciado por artistas 431 .

\section{Pesquisa artística como um problema coletivo}

\section{Uma discussão é feita neste capítulo sobre Você gostaria...? mais} próxima da linha poética relacionada aos processos de pesquisa, acadêmica e artística. Toda pesquisa nasce de um problema, de uma pergunta que a anima, que lhe dá hipóteses e que guia para a criação, através de uma resolução. Você

\footnotetext{
429 Em alguns momentos e textos, RB mostra-se interessado pela relação da amizade com a participação e a criação de circuitos, citando o livro do pesquisador espanhol Francisco Ortega, professor da UERJ no texto. Ver: Ricardo Basbaum, Circuito de Arte em Deslocamento, 2003; Francisco Ortega, Genealogia da amizade, 2002.

430 Nesse sentido, o trabalho de RB está conectado a uma série de artistas que começam a despontar no século 21, uma geração posterior a ele, como JMB, Graziela Kunsch, Vitor Cesar, Carla Zaccagnini, Traplev, Ducha, Raquel Garbelotti, Alexandre Vogler, Cristina Ribas, Diogo de Moraes, Fábio Tremonte, Claudio Bueno, Rosana Ricalde, Felipe Barbosa, Thiago Honório, por exemplo, e também a coletivos como Atrocidades Maravilhosas, Empreza, Frente 3 de Fevereiro, Contrafilé e Opavivará!.

${ }^{41}$ Ver algumas dissertações e teses brasileiras recentes que falam sobre comunidades, coletivos de artistas e espaços independentes: Fernanda Carvalho de Albuquerque, Troca, soma de esforços, atitude crítica e proposição, 2006; André Luiz Mesquita, Insurgências poéticas, 2008; Cláudia Paim, Coletivos e iniciativas coletivas, 2009; Bettina Rupp, Residências em arte contemporânea, 2017. Ver também: Marisa Flórido Cesar, Nós, o outro, o distante, 2014.
} 
gostaria...? nasce dessa dúvida, que recai sobre a própria arte e também sobre o modo como a obra se relaciona com as pessoas e vice-versa. Nesse caso, vemos também a pergunta como um convite para que a outra pessoa faça uma investigação, uma experiência livre sobre o campo da arte, ainda que, muitas vezes, essa experimentação ocorra em uma linha poética muito mais próxima da vida e do cotidiano. Vemos aí nessas perguntas uma sugestão de pesquisa, um convite à pesquisa artística, que pode ser feita por artistas ou não, dentro de uma ideia muito mais ampla de arte, e que é próxima da vida e de outros campos do conhecimento.

Projetos poéticos complexos como de JMB e RB exigem que se verifiquem as muitas linhas que funcionam nos planos de seus respectivos projetos poéticos, por isso se deve ficar atento para o fato de que apenas uma linha não dá conta de toda a poética desses artistas $4^{2}$. No caso de RB, pesquisadores, teóricos, críticos, curadores e artistas poderão explorar essa obra de arte, um trabalho em curso que se insere em um projeto poético mais amplo de RB, através de várias linhas poéticas, podendo ser da educação ou da mediação, da linha orgânica ou da escultura social, da performance ou da participação, do cotidiano ou do cinema, da arte postal ou do objeto técnico, do arquivo ou da história, da sociedade de controle ou da contaminação, da subjetividade ou do site-specificity, da comunicação ou da rede, entre outras, dadas a abertura e a complexidade de Você gostaria...?. Por outro lado, é colocado em relevo, contribuindo para o foco deste capítulo, as linhas poéticas relacionadas aos processos de pesquisa artística, dentro ou fora da academia. O objeto específico como um dispositivo para experimentações diversas é um instrumento de investigação por parte do artista gerenciador que dispara outras variadas pesquisas artísticas. No lugar do nome original da obra, partindo do contexto aqui colocado, pode-se perguntar também: Você gostaria de participar de uma pesquisa artística?

432 Ver outros tipos de discussões originais sobre Você gostaria...? em: Cecília Cotrim, Arte e deriva, 2008; Luiz Cláudio da Costa, O efeito-arquivo, 2009; Katia Maciel, Ricardo Basbaum: a geometria do conceito e a participação comunicacional, 2009; Brian Holmes, A personalidade potencial, 2011; Pablo Lafuente, Ricardo Basbaum, Or That Elusive Object of Emancipation, 2011. 
Depois de respondida a primeira pergunta - já que o "projeto é um ponto de interrogação, seu título é uma pergunta"433 -, é hora de responder a outro problema, como uma "pergunta dentro de uma pergunta" 434 , diz o artista. O que fazer com o objeto, em qual lugar, que tipo de resposta será dada? A decisão é de quem estiver com o objeto. Para RB, os participantes podem desenvolver experiências "a partir de temática ampla, tocando em questões em torno da arte e da vida, abordando o relacionamento entre o sujeito e o outro, conduzindo diretamente a processos de transformação" 435 . O lugar do artista é um lugar de produção do "poema", tal "como indica o próprio termo poiesis, um local de fabricação, de produção, de confecção" 436 , diz RB, para quem o poema ou obra de arte pode acontecer em variados circuitos, já que existem muitos modos de atuação do artista, pois "tanto o termo artista quanto o termo arte querem dizer muitas coisas"437. E a obra de arte, por sua vez, pode ser considerada um problema, pois o artista é "aquele que, em primeiro lugar, produz, fabrica (poiesis) e, em segundo lugar, produz/fabrica problemas, obstáculos" 438 . Nesse sentido, há uma aproximação da produção da obra de arte com a produção de experiências criadas pelo problema, ideia que é próxima do pensamento e da problematização coletiva sobre o corpo e sobre o espaço público. São problemas e são experiências, que apontam "para uma dimensão afetiva ou mesmo performativa" 439 .

Essa é uma obra de pesquisa artística empreendida tanto por RB quanto pelos participantes, como um "exercício coletivo de produção de pensamento sensível" ${ }^{40}$, um trabalho bastante conhecido não só por ter participado da documenta 12, mas pelo envolvimento de um número grande de artistas no Brasil: pessoas relacionadas a vários circuitos da arte, de programas de pósgraduação em Arte a coletivos e grupos em várias regiões do Brasil. Alguns

433 Ricardo Basbaum, Ana Kiffer e Renato Rezende, Ricardo Basbaum (Entrevista), 2013, p. 79. 434 “(?)? Pergunta dentro de pergunta" é o texto de uma palestra apresentada no Centro Cultural Oduvaldo Vianna Filho, no Rio de Janeiro, em janeiro de 1996, publicado em: Ricardo Basbaum, (?)? Pergunta dentro de pergunta, 2000.

435 Ricardo Basbaum, Você gostaria de participar de uma experiência artística, 2009, p. 61.

436 Ricardo Basbaum, Mediações, 2014, p. 28.

437 Ricardo Basbaum, Mediações, 2014, p. 27.

$43^{8}$ Ricardo Basbaum, Mediações, 2014, p. 28.

439 Ricardo Basbaum, Mediações, 2014, p. 29.

$4^{40}$ Ricardo Basbaum, Você gostaria de participar de uma experiência artística, 2009, p. 64. 
artistas e grupos de artistas brasileiros que fizeram experiências, além de Jorge Menna Barreto, foram Brígida Baltar, coletivo SIM ou ZERO, Grupo de Pesquisa Corpos Informáticos, Divino Sobral, Carla Zaccagnini, Cristina Ribas, Cristiano Lenhardt, Elaine Tedesco, Yiftah Pelled, Regina Melim, Teresa Riccardi, Jardim Miriam Arte Clube de Mônica Nador e a companhia teatral Ueinzz, entre outros. "Redes coletivas de produção de pensamento"441 são criadas para que as pesquisas artísticas de outros artistas entrem em colaboração com a pesquisa artística de RB. Quando RB convida alguém para participar de uma experiência artística, ele também está convidando a pesquisa daquela pessoa para adentrar a sua própria pesquisa. A partir disso, uma ideia de "produção coletiva do pensamento" é criada, pois todo participante "está efetivamente pensando o projeto, trazendo-o em direção a limites, testando possibilidades de seu funcionamento" 442 .

O artista está em busca de respostas para os problemas que ele endereça ao outro. Respostas que ele espera que venham dos participantes que são convidados a experienciar o objeto - "não somente com o objeto, mas também com os conceitos que vêm junto com o objeto" 443 , segundo ele. Ao conjunto de todas as respostas geradas pelas participações com o objeto no projeto Você gostaria..?, retornadas para o artista em forma de arquivos, o artista dá o nome de romance crítico, expressão que ele utiliza para nomear esse "grande conjunto de falas, também polifônico, um conjunto de investidas críticas em relação"444 a seu trabalho. O artista diz que a expressão, que foi incluída no diagrama de Você gostaria...?, surgiu em seu doutorado, porque ele foi percebendo que, nessa busca por "um jogo dialógico, de uma conversa coletiva", o projeto rumou para a constituição de um "pensamento coletivo". Além disso o artista percebeu que, sozinho, não conseguiria dar conta de todas as demandas e respostas dessas experiências, dadas a complexidade e a dimensão das conexões, e que faz parte da natureza deste projeto, que tem uma certa autonomia de funcionamento, a

${ }_{441}$ Ricardo Basbaum e Cecília Cotrim, Fluindo de diferença para diferença (Entrevista), 2007, p. 77.

442 Ricardo Basbaum, Você gostaria de participar de uma experiência artística $(+N B P), 2008$, p. 193.

443 Ricardo Basbaum e Duda Kuhnert, Sobre o et cetera (Entrevista), 2016.

444 Ricardo Basbaum e Duda Kuhnert, Sobre o et cetera (Entrevista), 2016. 
busca por "auxílio de outros colaboradores na construção de um discurso de múltiplas vozes" 445 . No momento em que o participante "manuseia esse objeto, testa os limites do projeto, responde às questões que eu coloco ali, pensa o projeto à sua maneira, produz formulações", ele acaba pensando sobre a arte e o próprio projeto. Este termo serve também para que a responsabilidade de leitura das participações não recaia totalmente sobre o artista, que passa a se configurar como um gerenciador das respostas trazidas pelos participantes. A função principal do artista nesta obra é ler e administrar o "romance-crítico", o conjunto de respostas "que jamais conduz a soluções de curto prazo, mas à lapidação do problema como joia preciosa de lento processamento"446. O objetivo final é que todos esses problemas e toda essa movimentação de experiências possam efetuar uma transformação na forma original de NBP.

A obra de arte nasce de "problemas e desafios" como uma investigação sobre os próprios "mecanismos de envolvimento do outro como participante", ou seja, investiga-se a participação "em um jogo de deciframento e produção de enigmas", objetivando a "produção de experiências" e experimentos com o objeto, para que "novos problemas, propostas" sejam também criados447. RB se vê como um autor paradoxal, um autor que está em busca de outros autores para que sua fala tenha sentido448, em uma associação muito próxima com a literatura, a música, o poema e a narrativa, e pode-se dizer aqui que destes campos em direção à pesquisa acadêmica e ao "discurso crítico e conceitual"449.

\section{Materialidade da pesquisa e da teoria}

Convergências e superposições entre texto e obra de arte, dissertação de RB para o mestrado da ECO da UFRJ, em 1996, sob a orientação de Rogério

445 Ricardo Basbaum e Cecília Cotrim, Fluindo de diferença para diferença (Entrevista), 2007, p. 73.

446 Ricardo Basbaum, Você gostaria de participar de uma experiência artística $(+N B P), 2008$, p. 184.

447 Ricardo Basbaum, Você gostaria de participar de uma experiência artística, 2009, p. 64.

448 Ricardo Basbaum e Edison do Carmo Arcanjo, Os Festivais de Verão em Nova Almeida e o Projeto "Você Gostaria de Participar de uma Experiência Artística?", 2014, p. 83.

449 Ricardo Basbaum, Você gostaria de participar de uma experiência artística $(+N B P), 2008$, pp. 189-190. 
Luz, está reproduzida na primeira parte do livro Além da pureza visual. Essa primeira parte é composta pelos capítulos “Migração das palavras para imagem” (publicado na revista Gávea em 1995), "Pensa com arte: o lado de fora da crítica", "Diagramas e processos de transformação" e "Ricas articulações", que falam sobre as relações entre texto e obra de arte, sobre os diagramas e também sobre o texto como obra de arte, fundamentado sobretudo pelas leituras de Michel Foucault (e sobre conceitos como enunciados e visibilidades, discurso, experiência, pensamento do lado de fora, ficção etc.450) e também de Gilles Deleuze e/ou Félix Guattari (e sobre conceitos como conceito, regimes de signos, pensamento como heterogênese, rizoma, multiplicidades, território, máquina abstrata, multiplicidade maquínica, diagrama etc.451). A dissertação aproxima-se: de artistas que trabalham a discursividade, a relação entre texto e imagem (ou diagrama), e o texto como obra de arte, como Marcel Duchamp, Joseph Kosuth, On Kawara, Paul Klee, René Magritte e o grupo Art \& Language; de experiências como o livro Aparelhos, colaboração entre o artista Waltercio Caldas e o crítico de arte Ronaldo Brito, uma "reflexão sobre a condição contemporânea da arte, envolvendo um pensamento sobre o funcionamento da obra, uma análise acerca do sistema de arte e seus limites"452; de Lygia Clark, por conta da ideia de "linha orgânica" e aproxima-se também de Hélio Oiticica, já que suas últimas obras têm um "sofisticado aparelho visual-conceitual"453. RB diz que todos os artistas que ele admira ou de quem procura se aproximar pensam na produção da obra de arte ao lado da produção discursiva. "Então, na medida em que sempre me interessou o uso da palavra, fui querendo aproximar esses campos em uma relação produtiva e estruturar o meu trabalho assim, para que eu não precisasse sair de um campo ou de outro." 454 RB não queria ser somente um crítico ou teórico, mas também um artista, para que a "poética da

450 Ricardo Basbaum, Migração das palavras para a imagem, 2007, pp. 22, 59-67, 92, 98.

${ }^{41}$ Ricardo Basbaum, Migração das palavras para a imagem, 2007, pp. 22, 25, 28, 33, 35, 51-54, 58-67, 70-71, 75-85, 100.

452 Ricardo Basbaum, Migração das palavras para a imagem, 2007, p. 102.

453 Ricardo Basbaum, Migração das palavras para a imagem, 2007, p. 102.

454 Ricardo Basbaum e Duda Kuhnert, Sobre o et cetera (Entrevista), 2016. 
obra" seja "também a poética da teoria e da crítica" 455 . Sobre o texto como obra de arte, RB discorre:

É a partir deste espaço intermediário, em que discurso e visualidade se entrelaçam, que textos podem ser pensados como "obra de arte" - não importa apenas que a frase seja tornada visual, plástica, com escala, textura, material, cor ou relevo, mas sim que sua presença se articule com a consciência da existência de interstícios e frestas, relações a serem agenciadas, dispositivos a construir 456 .

Teoria de artista, conceito elaborado na tese de RB, é um procedimento que envolve tanto produção de textos como obras de arte, "articulando teoria e prática a partir de um sistema de revezamentos plástico-discursivos" 457 , uma vez que texto e teoria se colocam, a todo momento, como obra de arte. $\mathrm{O}$ artista recriou esse conceito a partir da apropriação da expressão contida no texto “Reflection on/as Artists' Theories"458, publicado em 2006 pelo artistapesquisador alemão Michael Lingner, professor de História da Arte na Universidade de Ciências Aplicadas de Hamburgo. Segundo esse autor, desde o romantismo a teoria de artista vem sendo uma condição implícita da prática artística, sendo um dos elementos fundamentais para a produção artística de vanguarda. Suas análises se basearão nos escritos e nas teorias dos artistas Philipp Otto Runge, sobre a paisagem romântica; Adolf Hölzel, na passagem da Jugendstil para a arte abstrata; e Joseph Kosuth, na fronteira entre teoria e obra de arte. Fundamentado em Theodore Adorno, que alerta para a necessidade de consistência das teorias feitas pelos artistas, e Hans Belting, que fala sobre a

455 Ricardo Basbaum e Duda Kuhnert, Sobre o et cetera (Entrevista), 2016.

$45^{6}$ Ricardo Basbaum, Deslocamentos rítmicos: o artista como agenciador, como curador e como crítico, 2008, p. 72.

457 Ricardo Basbaum, Você gostaria de participar de uma experiência artística (+NBP), 2008, p. 4 .

${ }_{458}$ Michael Lingner, Reflections on/as Artists' Theories, 2006. 
necessidade de uma colaboração entre críticos, teóricos e artistas459, Lingner diz que a necessidade dos artistas em teorizar é um fator decisivo para a produção artística. A reflexão na teoria de artista pode ser subjetiva ou sistemática, o que não significa que essa teoria terá sempre um teor acadêmico. Ele também alerta para a necessidade dos padrões da pesquisa científica, em um jogo entre a subjetividade e racionalidade, de acordo com que ele chama de desenvolvimento histórico das ideias estéticas para que a teoria lançada pelo artista não seja arbitrária, historicamente inadequada. As teorias de artistas podem ser produzidas dentro da universidade, e mesmo que haja ambições científicas o caráter subjetivo e, às vezes, confessional não deve ser desconsiderado, fator que dispara embates e também reservas a respeito deste tipo de produção460. A teoria do artista criada na universidade transforma-se em um tipo de pesquisa artística, sendo que também pode originar um novo tipo de desenvolvimento artístico, sendo a teoria considerada obra de arte.

RB tem uma atividade intensa de criação de textos sobre a própria obra, criando um sistema conceitual que articula discursividade com a materialidade da produção artística. $\mathrm{O}$ artista nomeia seus escritos e suas teorias de artista por meio da ideia de ensaio-ficção, uma "escrita de invenção" 461 entre o ensaio e a ficção462, sendo que a expressão "ficção" entra para destacar a qualidade de "uma escrita que não abdica de um rigor qualquer, não abdica de uma produção conceitual, mas que quer se inscrever em um registro poético da reinvenção contínua"463. A expressão encontra-se no "bloco 1" tanto no diagrama do projeto Você gostaria...?, quanto na tese de doutorado de RB, próxima dos três conceitos chamados de tríade de NBP. A tríade de conceitos apareceu pela primeira vez no texto “O que é NBP?" e é composta das seguintes ideias: 1)

459 A esse respeito, Lingner diz que em 1985 junto com o artista Franz Erhard Walther lançou um livro em que essa cooperação entre o artista e o acadêmico da arte foi proposta, lembrando a parceria, aqui no Brasil, entre Ronaldo Brito e Waltercio Caldas. Ver: Ronaldo Brito e Waltercio Caldas, Aparelhos, 1979; Franz Erhard Walther e Michael Lingner, Zwischen Kern und Mantel, Klagenfurt, Kunsthalle Ritter, 1985.

460 Michael Lingner, Reflections on/as Artists' Theories, 2006.

${ }_{461}$ Ricardo Basbaum, Você gostaria de participar de uma experiência artística (+NBP), 2008, p. 101.

462 Ricardo Basbaum e Marina Fraga et al., Complexidade, metabiologia e criatividade (Conversa), 2014.

463 Entrevista concedida por RB, localizada no Anexo 2 desta tese. 
imaterialidade do corpo; 2) materialidade do pensamento; e 3) logos instantâneo. O segundo ítem dessa tríade é muito importante aqui porque fala sobre a relação entre o pensamento - originado da pesquisa, no entendimento buscado por este trabalho - e a visualidade ou materialidade da obra de arte. O artista desenvolve a ideia de materialidade do pensamento nestes termos:

O pensamento como algo que pode ser lançado, moldado, construído, acumulado, recolhido, contraído, expandido, amassado, jogado, corroído, revelado, ampliado, amplificado, estilhaçado, dissolvido, etc. O pensamento envolve as coisas, entre elas existe a atmosfera, com oxigênio, nitrogênio, gás carbônico, enxofre, chumbo, alumínio; mas também partículas de pensamento. Essas partículas desprendem-se dos nossos corpos e cérebros em fluxos além de nosso controle, aderindo aos objetos e a outros pensamentos; possuem campos gravitacionais e magnéticos potentes, e distorcem e alteram imagens, todas as imagens das coisas. O pensamento é, portanto, essencialmente carregado de potencialidade plástica 464 .

Além da materialidade do pensamento, RB fala sobre a materialidade da teoria, em conexão com a ideia de teoria de artista desenvolvida por ele em sua tese. A teoria de artista funciona como um "sistema de revezamentos plásticodiscursivos, admitindo a prática do artista funcionando nos termos de uma dupla-articulação visualidade/texto, acionando tanto a materialidade do conceito como a imaterialidade do visível"465. Teoria de artista que não está

464 O texto original de "O que é NBP?" apareceu pela primeira vez em uma performance no evento CEP 20000, ocorrido no Espaço Cultural Sérgio Porto, no Rio de Janeiro, em 1990. Esse texto é encontrado dentro de outros textos do artista, diagramado como um poema. A citação do trecho acima foi extraída da transcrição de uma conversa: Ricardo Basbaum e Marina Fraga et al., Complexidade, metabiologia e criatividade, 2014.

465 Ricardo Basbaum, Você gostaria de participar de uma experiência artística $(+N B P), 2008$, pp. 45-46. 
apartada da realidade, ela está no mundo e participa da obra de arte. Segundo $\mathrm{RB}$, a teoria de artista:

(...) não existe como construção independente da obra de arte - e, como tal, somente pode funcionar (isto é, produzir efeitos, constituir campo próprio) quando se conquista a possibilidade de construir tal encadeamento em modo perceptivo: a teoria de artista não se materializa enquanto objeto à parte; a teoria de artista é formada a partir do jogo duplo das idas e vindas entre obra de arte e discurso, resultando deste processo de busca e investigação, entrelaçamento e construção466.

Existe uma ligação entre a noção de ensaio-ficção proposta pelo artista e as ideias de materialidade tanto do pensamento quanto da teoria, em que a linguagem é tratada como "matéria flexível, massa informe a ser plasmada a partir de múltiplos recursos", tornando o "campo discursivo como matéria" 467 para a arte. RB diz que esse é um termo foucaultiano, porque "Foucault está em um embate com uma certa academia também, uma certa metodologia que impediria que ele colocasse o pensamento dele em um registro da urgência do presente”. Aqui o artista problematiza a questão dos protocolos da academia que poderiam atrapalhar o desenvolvimento pleno e livre das ideias elaboradas em uma pesquisa artística, determinados por protocolos que prejudicariam uma liberdade de trabalhar sobre a arte e as questões de agora. Por isso ele busca uma "escrita que fique, seja na academia, seja fora da academia, reivindicando um status do poético"468. E este escrito do artista também é a teoria que o artista faz sobre a sua própria obra. No caso de uma dissertação, tese ou qualquer outro tipo de resultado teórico proporcionado pela pesquisa artística, pode-se

466 Ricardo Basbaum, Você gostaria de participar de uma experiência artística $(+N B P), 2008$, pp. 62-63.

${ }_{467}$ Ricardo Basbaum, Você gostaria de participar de uma experiência artística $(+N B P), 2008$, p. 101.

468 Entrevista concedida por RB, localizada no Anexo 2 desta tese. 
imaginá-la também como um ensaio-ficção, uma "escrita que envolve os rigores do ensaio e as aventuras da ficção"469. O artista, com esse conceito, também conecta o campo textual, seja ele acadêmico, crítico ou teórico, com a obra de arte, pois trabalhar com ensaio-ficção, segundo o artista, "é desde logo assumir certas posições relacionadas à organização do campo discursivo como instrumento ou ferramenta de ação". ${ }^{470} \mathrm{O}$ artista imagina um entrelaçamento entre a questão material da obra ou o modo como ela é exibida com todos os processos discursivos que a atravessam, todas as camadas de textos, conversas, relações e participações, que são parte da obra de arte e não precisam necessariamente aparecer no espaço expositivo. Mas esse pensamento assume uma materialidade na obra, que não é somente aquela que é exibida, mas que se encontra espalhada e distribuída como partes de um sistema conceitual que o artista engendra através de diagramas e teorias de artista. $\mathrm{O}$ artista vai além, pois o pensamento que atravessa tanto o texto quanto a obra tem uma materialidade, um pensamento tratado como se fosse material artístico, podendo sofrer operações e alterações como construção, ampliação, estilhaçamento, contração, acúmulo, ou seja, o pensamento é colocado em um plano diagramático que extravasa para o ambiente da arte. No caso de uma pesquisa artística, pode-se dizer que esse pensamento extravasa para um ambiente de pesquisa, onde esta pode ser desenvolvida ou exibida.

\section{Obra de pesquisa espalhada}

$\mathrm{RB}$ trabalha séries e projetos que duram e se desenvolvem no tempo, como trabalhos em curso, como obras de pesquisa compondo o projeto poético, perfazendo um processo de pensamento artístico construído a longo prazo, assemelhando-se a um projeto de pesquisa acadêmica. Conversas-coletivas e re-projetando ${ }^{471}$ ampliam as perguntas colocadas por NBP e Você gostaria...?,

469 Entrevista concedida por RB, localizada no Anexo 2 desta tese.

470 Ricardo Basbaum, Você gostaria de participar de uma experiência artística $(+N B P), 2008$, p. 101.

471 re-projetando aconteceu pela primeira vez em 2002 em Porto Rico, e conversas-coletivas ocorreu primeiramente com o título escrituras-fala em 2010, no México e em Córdoba, na Argentina. 
com uma complexidade e combinatória maior, fazendo com que a obra de arte fique ainda mais espalhada, exibindo dispositivos visuais e discursivos de pesquisa espalhados e, dessa maneira, a percepção e experiência da obra ocorrem de forma mais esparsa, com participação ou cocriação menos identificável. Saber como a obra funciona, descrever seu funcionamento, nos mostra a complexidade dos jogos enredados criados pelos artistas, revela-nos as linhas poéticas ou as linhas de pesquisa, da pesquisa artística como obra de pesquisa, obra complexa e em rede, um diagrama-quadro propiciador de conexões e associações, pensamentos e sensações.

Baseando-se na explicação em três tópicos de RB sobre o funcionamento de conversas-coletivas ${ }^{472}$, pode-se dizer que os trabalhos começam com convites ou chamada pública para a formação de um grupo de pessoas que participará de uma oficina, com a orientação de RB. Pessoas específicas, convidadas ou selecionadas, começam a fazer parte da obra em torno de um tema proposto para discussão, que pode ser diferente de cidade para cidade473, e depende do contexto da exposição e do grupo formado. $\mathrm{O}$ artista diz que trabalha "com um grupo, na dimensão de um workshop ou de uma oficina", trazendo "algumas questões para deflagrar a conversa" 474 . Desse modo, depois de um tempo de encontros, há a redação e a formatação de um documento na forma de script, parecido com um roteiro de peça de teatro ou partitura musical,

472 Segundo RB, “(1) um documento é produzido, na forma de um script, contendo o texto da conversa e instruções de leitura; o documento pode ser publicado a qualquer momento; (2) uma leitura pública é realizada, sendo o script performado para uma audiência; a leitura se desdobra de acordo com uma dinâmica que inclui refrões, coros, diálogos, leituras paralelas e simultâneas, traduções, improvisações etc., seguindo as instruções do roteiro; (3) a leitura é gravada, o que resulta em uma peça sonora; o áudio pode retornar à instalação como uma camada sonora discursiva, que pode mediar o acesso futuro ao trabalho". Ver: Ricardo Basbaum, collective-conversations, 2012, p. 32. (Tradução do autor.)

473 conversas-coletivas vem acontecendo desde 2010 em variados momentos e cidades, tais como São Paulo (em 2016 na Casa Tomada, dentro do projeto Intervalo Escola de Claudio Bueno e Tainá Azeredo), Hamburgo (Stadtkuratorin, projeto de intervenção urbana), Estocolmo (Tensta Konsthall), Rio de Janeiro (Centro de Arte Hélio Oiticica e Festival Atos de Fala), Bienal de Kiev, Viena (Exposição Counter-Production e Academia de Belas-Artes de Viena), Santiago de Compostela (CGAC), Londres (The Showroom), Curitiba (Exposição Campo Neutral), Bienal de Busan, Guimarães (intervenção urbana no projeto Reakt - Olhares e Processos), Chicago (Logan Gallery da Universidade de Chicago) etc.

474 Ricardo Basbaum, Só funciona nessa responsabilização do outro por uma ação não idealizada

(Entrevista), 2013, p. 20. 
mas "um texto coletivo, de muitos autores" 475 . O texto é pensado e elaborado por todos do grupo, dentro das dinâmicas propostas nos encontros da oficina. O intuito da conversa-coletiva é ser uma leitura pública desse script, em certa proximidade com a performance e até com a palestra-performance (no caso, coletiva). RB inventa outro tipo de arte, próxima da orquestra de câmara ou da roda de samba, mas no lugar dos instrumentos musicais são utilizadas falas, pensamentos e ideias. Todos leem sentados, geralmente em círculo, cada um com um microfone. Utilizam-se, tal como instruído pelo script, recursos musicais e sonoros como refrões, coros, jograis, falas, diálogos, simultaneidade, barulhos e ruídos, palmas, improvisações. Conversas-coletivas, segundo RB, são uma maneira de "reconhecer na questão da escrita, quando lida, um mecanismo de produção de fala; reconhecer num endereçamento público da escrita o lugar da voz em público, que é um canto; e reconhecer os aspectos de sonoridade deste processo, da escrita, da leitura, da conversa" ${ }^{476}$. Ao final da experiência, resta a gravação da conversa, realizada no dia da leitura pública, muitas vezes disponibilizada ao público em um fone de ouvido no espaço da exposição.

Para o artista, a ação coletiva na forma de dinâmica de grupo, que vai resultar no script, dura enquanto o grupo está reunido, lendo, escrevendo, fazendo parte. "A aula formalizada está na escola e na universidade, mas a aula formalizada vem desse lugar, desse encontro. Antes de ter escola, ou universidade, tinha isso: as pessoas juntas conversando e tentando pensar, em um processo de escuta e fala" 477 . Há, assim, a abertura de um espaço que é "efêmero mas intenso" 478 . O resultado textual e sonoro é a produção desse roteiro ou partitura, que fica entre o poético, o teórico e a fala cotidiana, feita a partir de um coletivo de vozes criado como se fosse uma colagem de trechos de vários autores que, no limite, seriam citações, como as de um artigo científico, como uma colagem hipertextual de pensamentos. A imagem da oficina, nesse

\footnotetext{
475 Ricardo Basbaum, Só funciona nessa responsabilização do outro por uma ação não idealizada (Entrevista), 2013, p. 18.

476 Entrevista concedida por RB, localizada no Anexo 2 desta tese.

477 Entrevista concedida por RB, localizada no Anexo 2 desta tese.

478 Ricardo Basbaum, collective-conversations, 2012, p. 32.
} 
caso, é a imagem de um grupo de pesquisa a investigar um tema específico ou conjunto de temas, dependendo do interesse individual das pessoas que se propuseram a fazer parte e dentro de um breve período de tempo. Além disso, todos os desdobramentos de conversas-coletivas acontecem como processo de pesquisa do próprio artista sobre a discursividade do som e a musicalidade da fala.

Em 2012 RB fez uma conversa-coletiva na exposição Counterproduction na Generali Foundation de Viena, com curadoria de Ilse Lafer e Diana Baldon. A exposição desenvolveu-se através da ideia de contraprodução479 e foi composta de artistas480 cuja produção não é só de objetos mas também composta de textos, redes, ações, de questionamentos sociais e políticos, sendo que também se utilizam de diagramas e discursividade em suas obras. Uma das curadoras, Diana Baldon ${ }^{481}$, considera que as contraproduções artísticas dos artistas escolhidos falam sobre estratégias fora das convenções artísticas de produção, apresentação e comunicação, e partem de uma "tradição" que vem dos anos 1990, de uma arte que se articula com o pensamento social e político, relacionando-se com o ativismo, estratégias de colaboração e participação, e a diluição da Arte com outros campos. A oficina, a criação do script e a leitura pública aconteceram em torno de outros itens expostos por RB na mostra, nove vídeos da obra de pesquisa eu-você: coreografias, jogos e exercícios, e o diagrama Local/Global, de 2006. Discutiuse tópicos como geografia, corpo, globalização e memória. Ilse Lafer, que também fez parte da oficina, contou que, em um primeiro momento, os corpos dos doze participantes foram confrontados com o diagrama, formado de

479 Tal termo tem origem em Public Sphere and Experience, livro de 1972 do cineasta e escritor alemão Alexander Kluge e do filósofo Oskar Negt. É utilizado nessa exposição para demarcar alguns artistas que pensam estratégias artísticas para lidar ou se desviar do sistema da arte capitalista, utilizando-se desse mesmo sistema em um tipo de prática alternativa que intervém criticamente na esfera pública.

480 Além de Ricardo Basbaum, fizeram parte da exposição: Marion von Osten, Henrik Olesen, Seth Price, Josef Strau, Mary Ellen Carroll, Goldin+Senneby, Dexter Sinister, Marine Hugonnier, Johannes Porsch, Josephine Pryde e Lili Reynaud-Dewar. 
palavras e linhas, como se fosse um "aparato mecânico" que entra em contato com os corpos dos participantes criando diversas conexões 482 .

Re-projetando, obra de pesquisa que vem sendo realizada por RB desde 2002, tem por imagem principal a inscrição da "forma específica NBP" sobre o mapa de uma cidade determinada. A partir dessa justaposição são criados nós, e cada nó é um lugar qualquer e aleatório na cidade, que servirá de motivo para a realização de eventos e intervenções ou para investigações artísticas de leitura e exploração, conduzidas por outras pessoas ou coletivos. Segundo RB, reprojetando tem "clara proposição de viés curatorial", pois propõe o desenvolvimento de obras, ações, eventos e projetos sobre a cidade, de RB ou de outras pessoas, do campo da Arte ou de outros campos da cultura e também de pesquisa. "Então, de fato, o re-projetando foi caminhando nessa direção, de ser um projeto que fica no limite entre uma coisa curatorial e artística"483. A descrição dos detalhes do funcionamento de obras como as de RB é importante para o seu entendimento. Tanto é assim que o próprio artista costuma utilizar um texto em tópicos resumido sobre a obra, mostrando processos, associações e produções esperadas, e o faz como se fizesse a definição de um conceito. RB explica o funcionamento de re-projetando em quatro tópicos, e nomeia esse funcionamento em tópicos como "esquema geral de operações":

1) A forma NBP é projetada sobre um mapa, configurando uma proposta de intervenção/ 2) Os pontos em que os ângulos da forma NBP e seu círculo interno tocam o mapa são escolhidos como locais para ações, atividades, intervenções, palestras etc., relacionadas tanto a projetos de minha autoria quanto de convidados./ 3) Os locais selecionados funcionam como espaços para o desenvolvimento de propostas que atuam como interfaces entre as práticas contemporâneas (em arte mas também em outros campos e disciplinas), as áreas públicas ou

${ }^{482}$ Ilse Lafer, Counter-Production, 2012, p. 49.

483 Entrevista concedida por RB, localizada no Anexo 2 desta tese. 


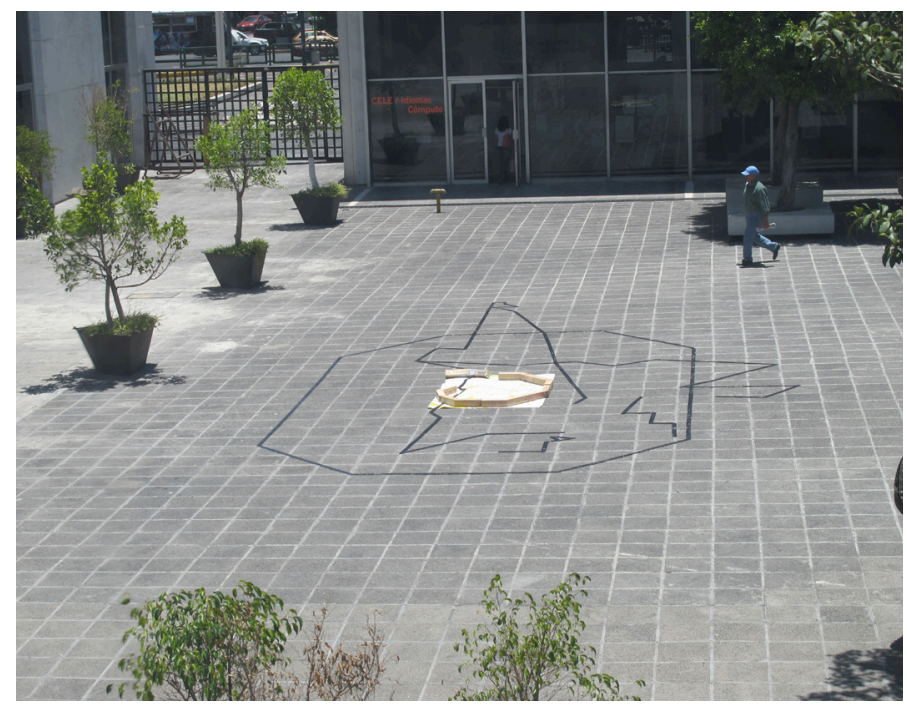

Ricardo Basbaum, re-proyectando (mexico), 2011. Oficina, ações urbanas, cartografia, dinâmica de grupo, áudio. Parte da programação do Taller de Medios Múltiples, ENAPUNAM, México DC.

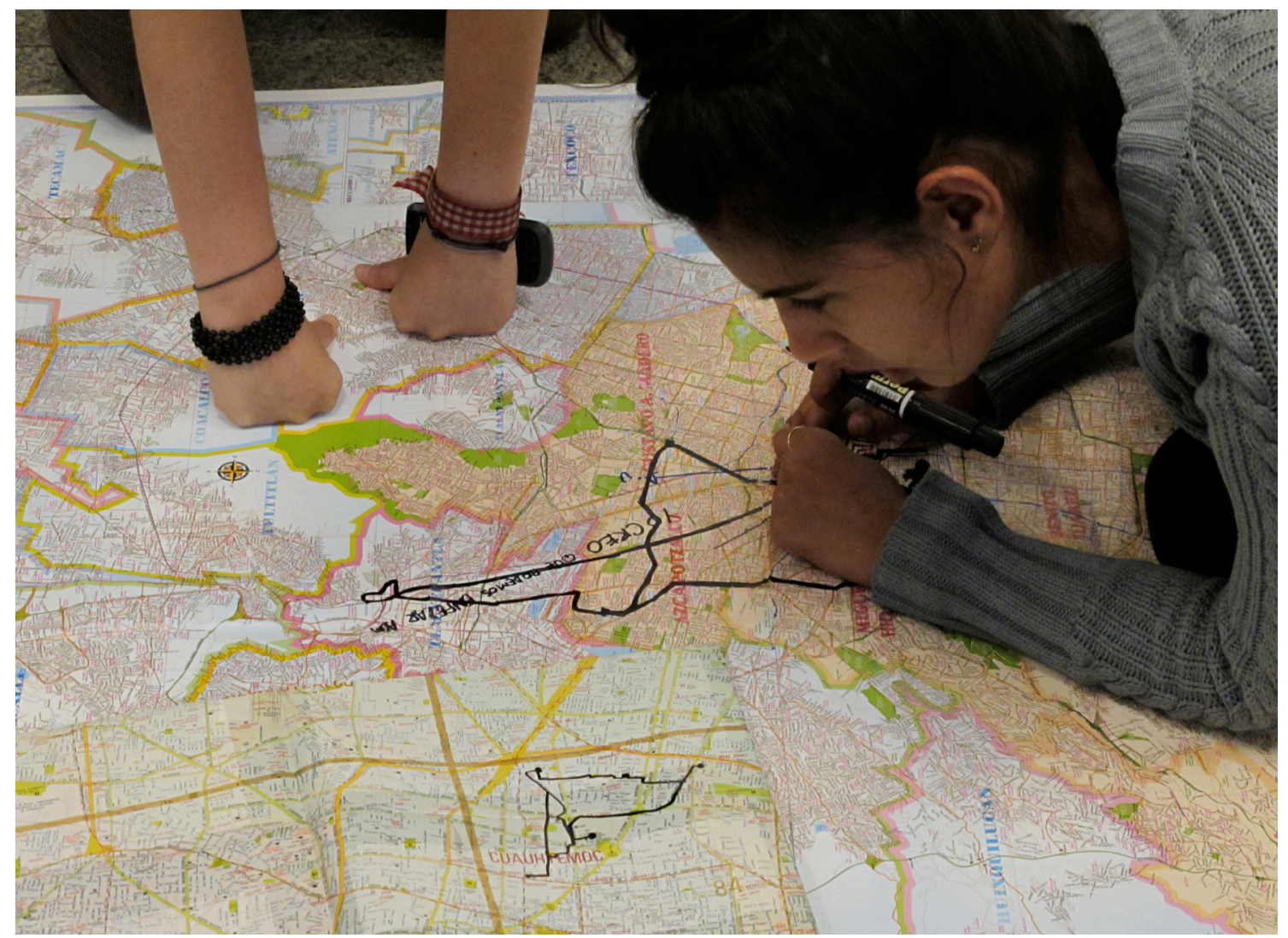



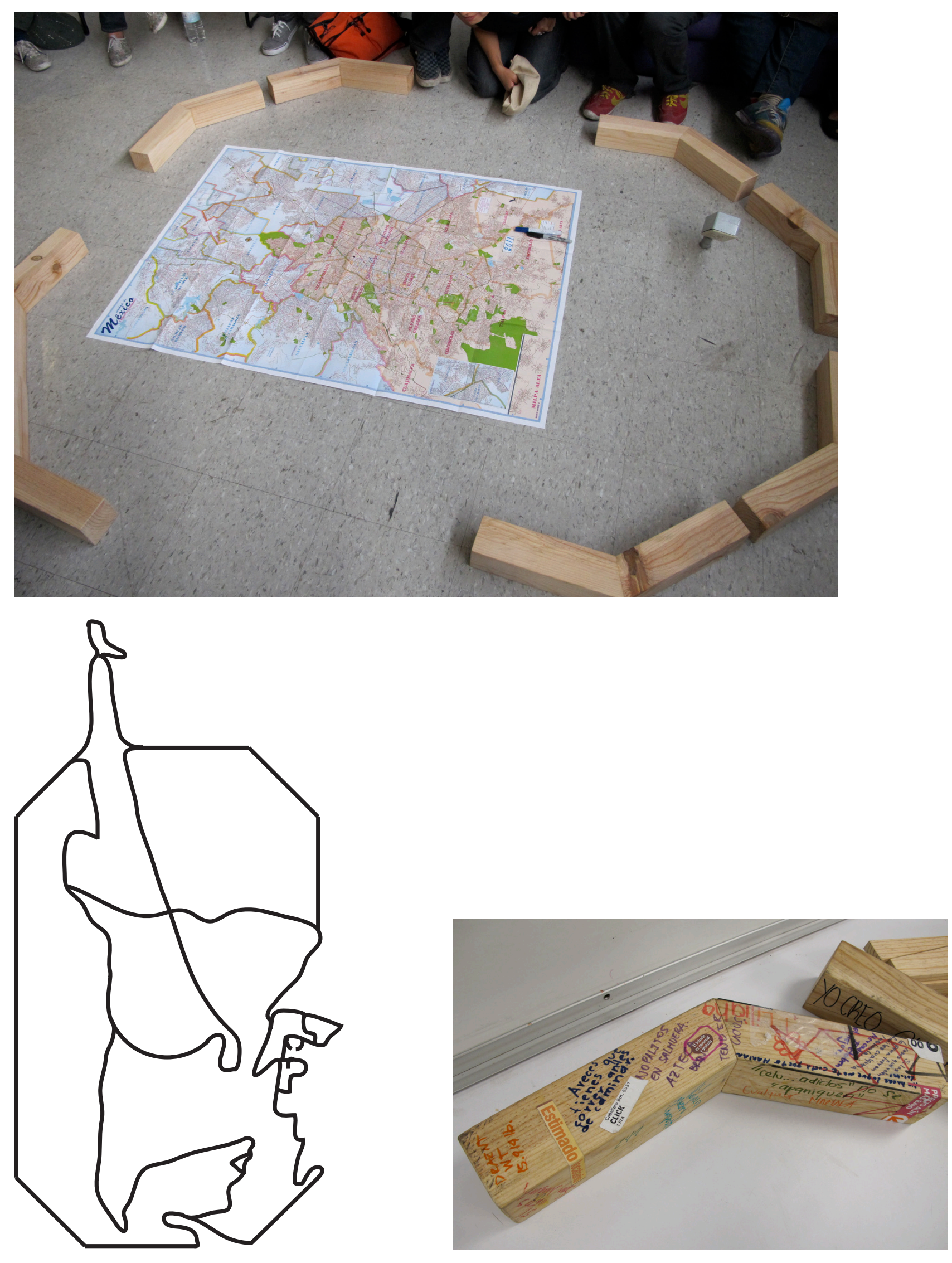
privadas e os indivíduos, grupos e comunidades que ali habitam ou trabalham./ 4) Espera-se a produção de uma tensão, caracterizada como conversação, negociação e provocação recíprocas 484 .

Outro objetivo de re-projetando é alterar a forma NBP, que começa a adquirir contornos diferentes, a partir da participação das pessoas que caminham na cidade. $\mathrm{O}$ artista diz que "quando o re-projetando foi aparecendo, antes do conversas-coletivas, ele foi tomando um rumo de um desenho coletivo", um desenho que se origina inspirado no percurso das pessoas envolvidas nesse projeto, que se estende na cidade em vários eventos. $\mathrm{O}$ artista diz que é como se ele pedisse ajuda para alterar a forma NPB, uma forma que o "persegue", pois sozinho ele não consegue fazer, como uma pergunta que ele sozinho não pode responder, por isso ele demanda "a um coletivo qualquer ajuda para trabalhar esse desenho". Então, re-projetando, "produz nessa projeção no mapa possibilidades de ações e eventos, que aos poucos foram gerando linhas e traços, gerando possibilidades de produção de um desenho coletivo que tem produzido alterações nessa forma" ${ }^{485}$.

Em 2008 aconteceu o re-projecting (utrecht), promovido por um instituto holandês de pesquisa artística chamado Casco486, e levado para nove lugares espalhados pela cidade de Utrecht, durante dez dias. A forma NBP foi desenhada com marcador sobre o mapa da cidade e os pontos de intersecção foram indicados com alfinetes coloridos. RB nos revela que antes de se determinarem o formato de cada evento proposto, atividades variadas com artistas, coletivos, pessoas da comunidade, pensadores e curadores, houve visita e pesquisa sobre cada local487. As especificidades do local determinaram o tipo de evento que aconteceria e sua duração. O evento 1 foi o "Word Play", uma

484 Ricardo Basbaum, re-projetando (utrecht), 2008.

485 Entrevista concedida por RB, localizada no Anexo 2 desta tese.

486 Casco é um instituto de arte em Utrecht na Holanda, fundado em 1990, que desenvolve e expõe obras e projetos experimentais ligados a pesquisas e teorias, do campo da arte e de outros campos, com forte acento social e político. Além de RB, obras de pesquisa de artistas como Martha Rosler (2010), Ei Arakawa (2010) e Stephen Willats (2008), por exemplo, ocuparam o local.

487 Ricardo Basbaum, re-projetando (utrecht), 2008. 
competição de tipo Poetry Slam, apresentações de poesia geralmente em tom performático, conduzida pelos poetas locais Casper Fioole, Bart Bleijerveld e Gijs ter Haar no playground público Bankaplein no bairro de Lombok. Participaram estudantes da Faculdade de Artes Visuais e Design de Utrecth (MaHKU) e do Instituto Holandês de Arte (DAI) de Arnhem. O evento também teve a colaboração do coletivo de pesquisa artística chamado Expodium, de Nikos Doulos, Friso Wiersum e Bart Witte. O evento 2 trouxe o projeto do artista holandês Mieke Van de Voort, chamado Generale Staten (Estados Gerais), que consiste em uma oficina com dinâmica de grupo seguida de uma performance-jogo. Os participantes são convidados a atuar como personagens em um jogo que parte de uma narrativa fictícia de uma ilha acometida por uma epidemia não identificável. O evento 3 se aproveitou do projeto colaborativo da dupla Iratxe Jaio + Klaas van Gorkum chamado Stay Inside - Close Windows and Doors ${ }^{488}$ que consistiu em envolver os moradores da região de Overvecht em um desfile de zumbis, o "Overvecht Zombiewalk", com aproximadamente 50 pessoas, pelas ruas do bairro até um shopping center. No evento 4 houve a intersecção de re-projetando com outra obra de pesquisa de $\mathrm{RB}$, eu-você: coreografias, jogos e exercícios (me-you: choreographies, games, and exercises). Nesse caso, além das dinâmicas de grupo com os participantes vestidos com camisetas "eu" ou "você", aconteceram duas palestras, uma da brasileira Cristiane de Morais Smith Lehner, professora da Universidade de Utrecht, sobre o uso do Diagrama na Física Teórica, focando em como equações complexas referentes a interação entre elétrons são expressas de forma mais simples através de diagramas. E outra palestra do brasileiro Mario Campanella489 sobre o movimento das pessoas no espaço público e sobre a importância desse fluxo de pedestres para o planejamento de áreas e edifícios de grande circulação. O tema dessas coreografias, jogos e exercícios, que aconteceram em uma praça próxima da rua Giraffedreef no bairro de Overvecht,

488 Foram realizadas oficinas para o estudo de filmes e do fenômeno desse tipo de caminhada. O trabalho foi refeito em Bilbao, no mesmo ano, o que resultou em uma publicação com imagens, textos e manifestos e na organização do Seminário Zombie.

489 O brasileiro Mario Campanella mora em Roterdã e é consultor de fluxo de pedestres, com vários projetos na área, principalmente de estações. Entre 2004 e 2006 fez parte do coletivo Stealth com Ana Dzokic e Marc Neelen. 
surgiu da união dos temas das duas palestras, em torno das ideias de evolução dos sistemas (de pessoas ou elétrons) no tempo. O evento 5 também aconteceu em torno da uma obra de pesquisa de RB, Você gostaria de participar de uma experiência artística?. O objeto NBP foi disponibilizado para a artista Marian Tang, que o colocou nos jardins de um parque comunitário chamado Tuinenpark Ons Buiten, no bairro de Voordorp, enchendo-o de água para o gato dela e colocando uma casa de passarinho bem acima do buraco do objeto. O evento 6 foi uma transmissão de rádio ao vivo chamada The Germ, do artista Steve Rushton, também professor no Instituto Piet Zwart de Roterdã, no entorno das ruas Pasteurstraat e Henriette Roland Holstraat. A peça de áudio fala sobre um encontro imaginário entre os fantasmas do cientista francês Louis Pasteur (1822-1895) e da poetisa e integrante do partido socialista holandês Henriette Roland Holst (1869-1952). O evento 7 foi uma conversa entre Simon Sheikh ${ }^{40}$ com o historiador Renger de Bruin, professor na Universidade de Utrecht, em torno de temas relacionados às esferas pública e privada. Aconteceu na sala da casa de Mariëtte Eijdems, moradora da Keukenstraat, uma rua localizada no centro da cidade. O evento 8 compôs-se de abertura da exposição e uma mesa-redonda com todos os participantes do re-projetando. E, por fim, o evento 9 encerrava o projeto com samba e churrasco em um complexo esportivo com quadras de futebol localizado justamente na rua Rio de Janeiro (ou Rio de Janeirodreef).

Em 2012 uma conversa-coletiva aconteceu como desdobramento de reprojetando na exposição individual de RB chamada conjs., re-bancos*: exercícios\&conversas ${ }^{491}$ realizada no Museu de Arte da Pampulha, em Belo

490 Simon Sheikh é curador e professor no Goldsmiths de Londres e possui artigos importantes para se pensar as relações da arte com educação, teoria e pesquisa.

491 Os conjs. e re-bancos são dispositivos estruturais que se conectam aos dispositivos discursivos e sonoros. Conjs. são conjuntos de metal e grades formando bancos, portais e obstáculos. Os re-bancos formam um círculo de bancos no mezanino do museu, algo como praça mas também sala para dinâmicas ou grupos de estudos. Os bancos foram desenhados para serem dispostos na forma octagonal NBP. Complementava a instalação microfones e dispositivos de gravação de áudio. Os conjs. apresentados no térreo do museu também continham fones de ouvido com uma peça de áudio lida por RB, com um texto sobre "atravessar os portais", "sentar nos bancos", "saltar os obstáculos". Segundo a curadora, "no Salão do térreo, os conjs. apresentam-se como uma espécie de parque de esportes e, no Mezanino, re-bancos conformam uma espécie de praça (...)”. Renata Marquez, Masterplan NBP, 2012, p. 8. 
Horizonte. Com curadoria de Renata Marquez492, a exposição fez parte do Projeto Arte Contemporânea, que tem por objetivo a ocupação artística do antigo cassino projetado em 1940 por Oscar Niemeyer. Sete artistas convidados foram instigados a trabalhar 493 sobre pontos demarcados no mapa, surgidos da intersecção com a forma NBP, de forma a mapear, ler e explorar poeticamente as regiões da cidade designadas para cada um. Alguns artistas fizeram leituras dos lugares, outros propuseram intervenções urbanas494. No texto do convite aos artistas podemos perceber a intenção do projeto de instaurar um grupo temporário de pesquisa: "Essa série propõe uma rede de investigações no âmbito das relações entre o espaço expositivo e seu entorno, envolvendo áreas da cidade e a colaboração de grupos locais" 495 . Aruan Mattos e Flavia Regaldo participaram fazendo recortes sonoros com a obra Cicloritmoscópio, projeto que é realizado a partir do movimento de um carrinho-máquina ambulante, misto de piano mecânico e brinquedo ótico, no bairro da Lagoinha. A atriz e professora de teatro Silvana Stein fez uma atuação silenciosa como um personagem sem nome, chamada Ação 5, pelas ruas do bairro Padre Eustáquio. Daniel Escobar, que tem um trabalho sobre cidades, mapas, guias de viagens e recortes, fez a sua pesquisa sobre o bairro Castelo. Os nós de re-projetando são "visualizados" no momento em que os participantes colocam suas falas nessa conversa. Breno Silva conversou com moradores da cidade, entre a Rodoviária de Belo Horizonte e o bairro da Concórdia, fez fotos e textos como uma espécie de cartografia subjetiva. A artista Brígida Campbell, por exemplo, revela no trecho do script dessa conversa-coletiva o traço burocrático, de segurança e vigilância da poética de $\mathrm{RB}$ em relação ao lugar visitado por ela: "caminho por entre grades ornamentadas e muros de vidro_alugo vagas para militares_a

492 Professora no curso de Arquitetura da UFMG, Renata Marquez é curadora e coeditora da revista Piseagrama. Sua tese Geografias portáteis trata de como a prática artística relaciona-se com os outros campos do conhecimento a partir da ideia e da imagem do mapa. Ver: Renata Moreia Marquez, Geografias portáteis, 2009.

493 Esse processo colaborativo aconteceu de 14 de dezembro de 2011 até a data da conversacoletiva, 4 de fevereiro de 2012, tal como podemos ver no blog utilizado para o processo de criação e que hoje serve de documentação. Ver: re-projetando $B H$, https://reprojetandobh .wordpress.com.

494 Ricardo Basbaum et. al., Conversa pública com Ricardo Basbaum, 2012, p. 85.

495 Ricardo Basbaum et. al., Roteiro conversa coletiva: re-projetando (belo horizonte), 2012, p. 27. 
propósito, o silêncio militar está por toda parte_ruas desertas_desertas de silêncio_ (...)" 496 . Fred Paulino, do coletivo Gambiologia, aproveitou para fazer a relação entre sua pesquisa artística e a de re-projetando, em um relato de como se deu sua experiência no bairro de Santa Terezinha. Suas deambulações pelo bairro se concentraram em três lugares: um ferro-velho, o Parque Ecológico da Pampulha e um dos "Toca da Raposa", centro de treinamento do time de futebol Cruzeiro. Nesses três lugares ele pode conversar e ouvir pessoas, ouvir a torcida cantando em um treino do Cruzeiro e perceber a musicalidade do sotaque mineiro. Por isso sua participação se deu como um "repente urbano".

Os artistas convidados trazem suas pesquisas artísticas para dentro do projeto de $\mathrm{RB}$, por isso o momento da conversa-coletiva é uma reflexão sobre a pesquisa tanto de RB quanto dos participantes, e isso fica evidente no texto do script produzido. $\mathrm{O}$ artista, entre as falas dos outros artistas pesquisadores, insere um texto seu que teoriza sobre o que são as conversas e re-projetando: "Os locais selecionados funcionarão como interfaces entre as práticas contemporâneas e as investigações ali conduzidas pelos colaboradores, apontando para a produção discursiva em suas dimensões de registro escrito e derivações sonora"497. Em outro trecho do script, o artista aproveita para fazer uma explicação sobre o que são as conversas-coletivas. RB diz que as conversas produzem nós e perspectivas através do "contato de vozes diversas" que fazem a "ocupação do espaço comum", com sonoridades e vibrações. As conversas são uma "abertura performativa que precisa ser experimentada, testada", já que são também "um modo das politizações e processos" 498 . Não é somente um laboratório de experimentações com as sonoridades do texto lido, mas pode-se pensar em um laboratório de pesquisas muito mais amplo de investigação (científica e artística) sobre as associações de pessoas, sobre os temas artísticos, sobre outros campos do conhecimento que os participantes estejam estudando. As muitas vozes das conversas-coletivas são como se fossem as vozes de uma

496 Ricardo Basbaum et. al., Roteiro conversa coletiva: re-projetando (belo horizonte), 2012, p. 30.

497 Ricardo Basbaum et. al., Roteiro conversa coletiva: re-projetando (belo horizonte), 2012, p. 33.

${ }_{498}$ Ricardo Basbaum et. al., Roteiro conversa coletiva: re-projetando (belo horizonte), 2012, p. 42. 
pesquisa acadêmica populada por autores e citações como contribuições à pesquisa em curso. RB agencia interesses de projetos que têm uma urgência e uma atualidade, por exemplo, em torno da cidade, da participação, da colaboração e de várias linhas poéticas que partem do social ou da política, ou de outros temas importantes para a arte contemporânea, em uma produção de pensamento que nasce da conversa, um "pensamento-voz"499. Foram escolhidos artistas que naquele momento tinham um "modo de pensar" e um engajamento sobre a exploração poética e política da cidade e que faziam sentido para a conversa. A pesquisa artística, com um receptáculo formatado por $\mathrm{RB}$, um componente agenciador, abre-se para as pesquisas específicas de seus convidados. Quando RB chama outros artistas, deste modo, ele acaba atuando como produtor cultural, curador e pesquisador da arte e da cultura contemporânea. Ele se coloca sobre o agora e a arte a partir de um projeto que pede a colaboração do outro. A conversa - também obra de performance e obra de peça sonora -, tal como lida no script, revela o funcionamento das camadas textuais do projeto que não ficam visíveis ou claros apenas com a participação no espaço expositivo, interagindo com as estruturas dos conjs. e dos re-bancos ou fazendo a leitura do diagrama. O funcionamento tampouco será apreendido somente com o catálogo, onde há o texto do artista, da curadora da mostra, dos acadêmicos chamados a ajudar na leitura crítica. O funcionamento da obra só é percebido em uma tentativa de reconstituição ou rearranjo, um esforço para que a maior parte das peças seja colocada sobre o plano, em uma leitura atenta que deve buscar refazer, repensar e reconectar os processos complexos sugeridos pela pesquisa artística, onde objetos, conversas, dispositivos, linhas poéticas e conceitos espalhados são lidos e conectados.

499 Tal como escrito no diagrama criado e exposto na exposição de Belo Horizonte, em uma parede do mezanino. 

CONSIDERAÇÓES FINAIS 

O fenômeno recente da pesquisa artística foi motivado pela transformação e incorporação, em alguns países europeus, das academias e escolas superiores de arte em universidades, que se ocupavam somente do ensino e da produção artística, até então. A pesquisa, que não estava institucionalizada e não era uma preocupação, tem no doutorado em Arte o seu momento inaugural, para aqueles que pretendem construir uma carreira acadêmica ou se veem obrigados a conquistar a titulação de doutor para ser professor na universidade. Por isso, uma das razões para que exista a pesquisa do artista na universidade, seja no Brasil, seja em outro país, vem dessa exigência institucional. Os cursos de mestrado e doutorado são momentos privilegiados da pesquisa artística, mas o percurso é maior, encontra-se além da tese e da dissertação, não se resume ao momento de formação, pois os artistas podem apostar em uma carreira na universidade, ao mesmo tempo como professores e pesquisadores, participando de congressos, publicando livros e artigos, engajando-se em grupos de pesquisa, orientando futuros artistas mestres e doutores, entre outras atividades. Portanto, para acontecer, a pesquisa artística na universidade precisa do reconhecimento manifestado pelo financiamento público constante, com auxílio para grupos de pesquisa e congressos, bolsas para os professores orientadores e demais pesquisadores, mestres e doutores dos programas de pós-graduação em Arte.

A distância histórica permite ver com mais clareza o notável desenvolvimento e a consistência que a pesquisa em arte, as "Poéticas Visuais", os mestrados e doutorados em Arte alcançaram no Brasil, em uma série de batalhas e também de fatos paradoxais - como ter seu início em pleno regime militar, contradição que se verifica também em uma série admirável de experiências e resistências artísticas do período -, e permite ainda observar como foram criadas as circunstâncias para que a pesquisa do artista na universidade fosse institucionalizada e colocada ao lado de outras áreas do conhecimento e modos de fazer pesquisa com mais tradição e história. Impressiona como esse foi um debate do qual fizeram parte também os próprios artistas, uma demanda que convergiu com as preocupações e interesses da cena da arte, em um trânsito que proporcionou o desenvolvimento e o 
direcionamento desse novo tipo de atividade, prática e produção para o artista. Faz parte dessa disposição a boa relação e convivência entre historiadores da arte, artistas e demais profissionais das Artes Visuais, compartilhando os mesmos circuitos, ambientes, revistas, livros, grupos de pesquisa, congressos.

A preocupação sobre o curso de doutorado, visto como uma novidade nos últimos anos em países como Holanda, Áustria, Suécia e Portugal, por exemplo, deve-se ao fato de que a pesquisa artística promovida na academia é ainda inicial nesses países. Olhando a trajetória de países como Inglaterra e Brasil, percebe-se a pesquisa artística em um estágio de maior complexidade, com um grande número de programas de pós-graduação estabelecidos e artistas doutores. Nesse sentido, uma das contribuições desta tese é ressaltar a importância do exemplo brasileiro, pois nas bibliografias europeia e americana sobre o tema o Brasil não é citado como um dos países pioneiros dos programas de pós-graduação em Arte. Ainda que as primeiras experiências realizadas aqui tenham sido exemplos corajosos de pesquisa artística de produção, são mencionadas apenas as experiências desenvolvidas no Reino Unido, Austrália, Japão e Finlândia. Fazer a relação entre pesquisa em arte no Brasil e o artistic research europeu é outra contribuição desta tese, proporcionando a associação da história de estabelecimento da pesquisa do artista nas universidades brasileiras em relação a essa movimentação mundial da Arte sobre a pesquisa e o conhecimento.

Na Europa, embora muitos artistas tenham participado das discussões sobre a pesquisa artística, estas se concentraram mais nos aspectos institucionais de sua validação e definição no meio acadêmico e pouco na ideia de pesquisa que incide nas obras dos artistas, uma das características principais da arte contemporânea. Ainda que muitos autores tenham tratado de métodos e de poética da pesquisa artística, pouco se falou das obras de arte e dos projetos poéticos ou, ainda, mesmo que os interesses institucionais não fossem os mesmos que os poéticos, ambos eram tratados sem diferenciação em muitos discursos, o que vem gerando ambiguidade, e às vezes desinteresse, sobre qual é o lugar da pesquisa artística, se é apenas um fenômeno que acontece na 
universidade ou um fenômeno mais extenso que vem da poética de muitos artistas.

Essa incerteza ocorre em razão do ineditismo dessas propostas em muitos países e da necessidade, no ambiente acadêmico, de equiparar-se às outras disciplinas, para ser reconhecida como um tipo de pesquisa válida, e se ver incorporada à universidade. Um dos entendimentos importantes que se deve ter sobre o fenômeno da pesquisa artística é que existe essa dupla movimentação: 1) a pesquisa do artista institucionalizada na universidade e 2) o interesse renovado dos artistas pela pesquisa, pela Ciência, pela reflexão teórica, pelo conhecimento e por diversas disciplinas, uma característica forte da arte contemporânea, um interesse colocado em relevo pelos artistas quando se encontram pesquisando na universidade.

Depois dessa fase de estabelecimento dos doutorados em Arte na Europa, e conforme mais artistas vão trabalhando sobre os processos e significados da pesquisa, percebe-se um direcionamento das discussões para a própria poética dos artistas - ainda que essas poéticas sejam repletas de discussões críticas sobre a institucionalidade -, pois são muitos os problemas a serem enfrentados pelos artistas interessados em desenvolver produções artísticas que se orientam à pesquisa, como a dificuldade de exibição e de recepção pelo público desse tipo de produção.

O modelo de doutorado de pesquisa de produção artística, tal como desenvolvido pela ECA-USP entre as décadas de 1970 e 1980, é o que vem sendo almejado pelas academias de arte europeias, em vista dos muitos debates que se sucederam em torno das relações entre "teoria" e "prática", da validação da pesquisa artística como "pesquisa baseada na prática”, e do argumento da produção artística como produto do conhecimento. $\mathrm{O}$ artista que se propõe pesquisador universitário tem que estar disposto a ler, criar textos, refletir de forma sistemática, ainda que poeticamente, a discursar sobre a obra de arte para torná-la pública. Percebe-se, a partir da experiência brasileira e dos artistas lidos nesta tese, que a ideia do que pode ser a pesquisa do artista na universidade é uma questão muito mais complexa que a dicotomia teoriaprática. Depois de um período de estabelecimento, adversidades e discussões, a 
pesquisa do artista pode ser entendida de uma maneira mais abrangente, compreendendo a pesquisa de produção artística, a pesquisa teórica e vários níveis de entrelaçamento entre esses estados, não importando a predominância conferida para determinada pesquisa ou outra. Dadas a abertura e a complexidade da arte contemporânea, o artista deve ser livre para colocar em relevo qualquer um dos estados da pesquisa artística sobre seu projeto poético ou sobre uma obra de pesquisa específica. Ao final, o que fica dessas relações e embates é a criação de um lugar próprio para o artista na universidade, delimitado por programas de pós-graduação em Arte.

A pesquisa artística assume diversos contornos e estilos, é realizada de um modo específico, dependendo da legislação e do sistema universitário de cada país, e vincula-se, caso seja poética da obra de arte, ao modo como cada artista trabalha e se propõe como pesquisador, e principalmente ao tipo de pesquisa que é trabalhado por ele. JMB e RB são professores da universidade pública, autores de textos importantes para a arte brasileira na forma de artigos, dissertações e teses, criam conceitos artísticos para lidar com suas próprias obras ou a de outros artistas, com intensa atividade de publicações em revistas e livros, criam aulas, oficinas, palestras e outras produções discursivas consideradas obra de arte; transitam de forma ativa em grandes exposições e bienais, bem como em variadas esferas e instituições; trazem a arte para perto do conhecimento e o pensamento, considerados em sua face coletiva e pública, em uma discussão teórica que pede a colaboração de outros artistas e profissionais da Arte, e também pesquisadores de outras áreas do conhecimento. São artistas importantes para a arte contemporânea brasileira, parte de uma geração que não faz distinção entre a pesquisa realizada na universidade e aquela que é feita em vários circuitos artísticos. É uma pesquisa que se dá de forma prospectiva, em que a reflexão sobre a obra de arte é feita para o futuro, estabelecendo teorias e conceitos que farão sentido no projeto poético, uma trajetória poética a longo prazo, em que todas as obras de arte e todos os conceitos, anteriores e futuros, são conectados. A linha poética da pesquisa atravessa seus projetos poéticos, porque eles incluem um questionamento sobre a pesquisa artística e a imagem do artista que é 
pesquisador em seus textos; consideram a produção artística vinculada ao universo discursivo e teórico, em que a criação dos conceitos está atrelada à obra de arte; utilizam conceitos e montam sistemas conceituais poéticos que parecem saídos de outro campo do conhecimento; pensam a arte e sua relação com a teoria, aquela que é feita por filósofos, pesquisadores e críticos mas também aquela que é feita pelos artistas; trazem o conhecimento e o pensamento para um ambiente de discussão pública e coletiva, desenvolvendo atividades participativas em torno de palestras, oficinas, aulas e conversas; aproximam-se da literatura e da poesia, não só da poesia visual mas a partir das imagens que surgem da leitura; utilizam diagramas como dispositivos de exibição da pesquisa e desenvolvem um pensamento diagramático; propõem obras de arte que podem ocorrer dentro de obras de arte de outros artistas, assim como outros artistas também acabam participando de suas obras; por fim, seus projetos poéticos extrapolam o espaço expositivo ou o tempo da exposição, espalhando-se em vários eventos e conversas, distribuídos por vários dispositivos, objetos, ações e vivências.

$\mathrm{O}$ artista se aproxima da pesquisa, pensa seu projeto poético orientado à pesquisa, cria obras de arte, de fato ou poeticamente, que incluem processos de pesquisa, motivados pela imagem e pelo ambiente da pesquisa e, além disso, fazem com que a obra se torne reflexiva, teórica e discursiva. Desse modo, pesquisa artística é uma expressão usada aqui amplamente para significar muitas coisas, a pesquisa do artista na universidade e a pesquisa inserida na obra de arte. Além de resolver uma questão institucional, de especificar e delimitar um lugar e uma condição para o artista, que agora se vê como pesquisador dentro do sistema universitário, envolvido com o ensino e a pesquisa, expressa uma particularidade da produção artística contemporânea, no momento em que a pesquisa se torna poética da obra, provoca relações transdisciplinares, associa-se a outros campos do conhecimento, colocando em crise a própria ideia de exibição. Nesse sentido, muitos artistas e grupos compartilham com JMB e RB as qualidades da linha poética da pesquisa, trilhadas nesta tese, criando obras de pesquisa que se apropriam de outros campos do conhecimento, ou se associam a eles, movendo-se de forma 
transdisciplinar, imaginando-se como artistas-pesquisadores, artistas como historiadores, artistas como etnógrafos, antropólogos, educadores, paleontólogos, mineralogistas, urbanistas, designers, biólogos, em muitos casos inseridos em debates políticos, independente de serem doutores ou estarem atrelados a programas de pós-graduação. Entre os brasileiros estão Maria Thereza Alves, Carla Zaccagnini, Mabe Bethônico, Jonathas de Andrade, Graziela Kunsch, Vitor Cesar, Tamar Guimarães, Beto Shwafaty, Leandro Cardoso Nerefuh, Cláudio Bueno, Ícaro Lira etc. Entre os estrangeiros, podem ser citados Thomas Hirschhorn, Hito Steyerl, Nikolaus Gansterer, Falke Pisano, Wendelien van Oldenborgh, Walid Raad, Goshka Macuga, Simon Fujiwara, Mariana Castillo Deball, Mark Dion, Christian Philipp Müller, Ursula Biemann, Andrea Fraser, Bik van der Pol, The Otolith Group, Raqs Media Collective, Forensic Architecture, entre outros. Ao mesmo tempo que há a transformação do artista-professor para o artista-pesquisador, acontece uma movimentação da pesquisa artística da universidade para outros circuitos artísticos, e vice-versa, pois o problema encontra-se na obra de arte, nos processos de pesquisa artística que resultam em obras de arte, ou no próprio processo de pesquisa que começa a ser considerado, exibido, publicado, apresentado e comunicado como obra de arte, utilizando vários meios e métodos, espalhado como pesquisa por diversos ambientes e circuitos. Além disso, os artistas trazem para dentro de seus projetos a participação de cientistas, filósofos, teóricos ou especialistas em algum assunto específico, onde vários tipos de pesquisadores são convidados a colaborar dentro de projetos de natureza discursiva, como palestras e oficinas, ou através de textos e livros considerados partes da obra de arte, disposta como um ambiente teórico, discursivo e de pesquisa.

Essas colaborações com outros campos do conhecimento vêm ocorrendo de forma mais variada do final do século 20 para cá, embora conversas entre a Arte e Ciência venham acontecendo com mais intensidade desde o final do século 19. São relações que estabelecem significados complexos, pois acompanham o desenvolvimento das outras disciplinas e o modo como o conhecimento vem sendo caracterizado através das épocas. A pesquisa do artista entendida aqui em sua relação com outros campos do conhecimento é 
uma arte que se aproveita do funcionamento teórico e diagramático que decorre de pesquisas efetuadas nas mais variadas disciplinas, e até sobre conhecimentos considerados não científicos. O que hoje é comumente nomeado como Artes Visuais sempre esteve em diálogo com outras disciplinas: de forma intrínseca e fundante com a Filosofia e, através dos tempos, em estreita relação com a Química, a Matemática, a Física e a Biologia. Está na raiz da Arte esta condição ambivalente e mutável, que fica entre a distinção e a indistinção com os outros saberes, princípio que pode ser rastreado em épocas em que muitas dessas disciplinas ainda não existiam, não estavam delimitadas por esses nomes ou, ainda, apresentavam-se em estado de indistinção com a arte, considerada no seu sentido primevo, como técnica ou representação (arte rupestre, domínio dos materiais, criação de artefatos). Através da história, a relação da arte com outros tipos de saber acontecerá de muitas formas, tanto por parte das disciplinas, que se serviram das técnicas de representação desenvolvidas de modo compartilhado com a arte, ou da arte, que se aprimorou tecnicamente no desenrolar dos estudos e das práticas sobre as substâncias e os pigmentos; a luz e a cor através da Ótica; o corpo humano e a Anatomia; os estudos racionais da forma, da proporção e da perspectiva, vistos com a Geometria.

"Pesquisa" é uma palavra-chave, assim como também são palavras-chave as palavras "educação", "conhecimento", "academia". Artistas e teóricos se afeiçoaram ou se afeiçoam a certas palavras dominantes, sendo que algumas também podem ser linhas poéticas, como "belas", "plásticas", "vanguarda", "ready-made”, "conceitual”, "contemporâneo", entre outras. Claro que não são só palavras mas denominações que ajudam a circunscrever um campo e entender determinados processos de criação, produção e exibição artística. Da mesma forma que anteriormente a arte se debruçava com mais ânimo sobre os significados das palavras "ciência" ou "tecnologia", hoje há um interesse maior dos artistas sobre os significados transdisciplinares da palavra "pesquisa", a pesquisa como um modo de trabalho, com um entendimento do processo de produção artística que se dá a partir da pesquisa e como pesquisa. Isso pode ser percebido no número de artistas que se reconhecem através da imagem do pesquisador, que se dizem pesquisadores. Porém, o interesse desta tese não é 
dirigido a qualquer processo de pesquisa realizado pelo artista, mas a um tipo que se desenvolve simultaneamente a outras pesquisas e preocupações urgentes da atualidade. Não é só um interesse pelas Ciências ou pela atitude científica, mas, antes, um interesse pelo conhecimento e pensamento novo, a partir de tópicos privilegiados do debate contemporâneo. A pesquisa artística, antes de ser uma disciplina, é um "estado de invenção" intelectual por parte do artista, que elabora um processo de pensamento associado a processos de outros campos.

A obra de pesquisa é uma obra de arte espalhada e distribuída, complexa e sistêmica, aberta e instável, diagramática e esquemática, composta de várias partes espalhadas e distribuídas no espaço e no tempo, criada e exibida em vários lugares, artísticos e não artísticos, guarda a imagem dos outros campos do conhecimento, dos quais se apropria ou com os quais se associa, constituindo-se de diversos dispositivos, inclusive tradicionais, e apresentando um funcionamento próximo ao da pesquisa e da teoria, enquanto projeto poético transdisciplinar e colaborativo, onde podem participar o público e diversos artistas, grupos e pesquisadores, não sendo restrita ao projeto de um único artista. A obra de arte, além de não manter as qualidades estáticas da pintura, da escultura e de outras categorias artísticas particularizadas de forma tradicional, é composta por todas as partes integrantes de um trabalho em curso, num processo que se estabelece a partir da rede, onde não só a autoria é diluída em decorrência da colaboração entre artistas e pesquisadores das mais diversas áreas, mas a própria obra de arte passa a não ser mais considerada como um produto indivisível e, no limite, como aquilo que é exibido em uma exposição de arte, no momento em que a obra de pesquisa passa a se localizar em vários pontos, compondo-se de muitas atividades, experiências, ações, vivências, estratégias, processos, dispositivos, objetos, em direção às discussões mais urgentes.

A pesquisa artística, como uma das manifestações mais consistentes da arte de agora, é preocupação de curadores, museus, educativos de museus e exposições, embora tenha qualidades que permitem às obras de pesquisa apresentarem-se desvencilhadas da ideia de exibição. Um dos problemas da arte 
do século 21 já não é mais saber se "isto" é ou não arte, mas antes um questionamento sobre as formas estabelecidas de criação e exibição de obras. Em primeiro lugar, a criação de obras sofre uma mudança significativa porque é feita cada vez mais a partir da pesquisa, de processos investigativos sobre assuntos, materiais, métodos, acontecimentos, livros, pessoas e lugares específicos. A obra de pesquisa não é o resultado da pesquisa artística que se destina a produzir objetos cuja única finalidade é a exibição, mas uma arte que coloca o problema da exibição da complexidade, da imaterialidade, da discursividade e da temporalidade dos processos de pesquisa.

A obra de pesquisa também pode ser considerada uma obra de resistência ao mercado, à institucionalização e à preponderância dos pensamentos instituídos e dominantes, aproximando-se dos debates e das pesquisas políticas e sociais, em variados tópicos trabalhados de forma intensa nos últimos anos. JMB e RB representam uma geração de artistas que encontrou na universidade pública brasileira um lugar para a produção, a reflexão e a conversa, em torno de questões como a discursividade, a participação, o convívio, o lugar, o público. A pesquisa artística é uma conquista para a área de Artes no momento em que é considerada uma área de pesquisa acadêmica, reconhecida pelas agências de fomento, e a obra de arte ou projeto artístico é, então, reconhecida e entendida em relação a outros produtos e objetos de pesquisa. Por outro lado, a pesquisa artística se move de modo independente em vários circuitos artísticos, com acesso a outros espaços de pensamento e distribuição. O funcionamento da obra de pesquisa, como um atributo poético, é um elogio à própria pesquisa e ao conhecimento, à universidade pública no Brasil e às conquistas da pós-graduação dos últimos anos para cá, principalmente sobre a criação de um lugar próprio do artista no meio acadêmico. Porém, implícitas neste estudo, também estão a preocupação e a resistência aos ataques que insistem em incorrer sobre a pesquisa e a universidade. 



\section{ANEXO 1 \\ ARTISTAS-PESQUISADORES \\ SOBRE \\ A PESQUISA DO ARTISTA \\ NA UNIVERSIDADE}



Dez importantes artistas brasileiros que são pesquisadores universitários, inseridos em programas de pós-graduação próprios para o artista - Bia Medeiros (UnB), Gilbertto Prado (USP), Hélio Fervenza (UFRGS), José Spaniol (Unesp), Livia Flores (UFRJ), Mabe Bethônico (UFMG), Milton Machado (UFRJ), Milton Sogabe (Unesp), Raquel Stolf (Udesc) e Sylvia Furegatti (Unicamp) -, foram chamados a ajudar a esclarecer algumas questões feitas nesta tese sobre a pesquisa do artista na universidade, tais como a relação entre produção artística e produção de texto, e a movimentação do artista-pesquisador em vários circuitos. Foi pedido aos artistas que assinalassem as afirmações que estivessem mais próximas de seu contexto acadêmico, por regra ou tradição do programa de pós-graduação em que eles atuam ou por preferência dos próprios artistas-pesquisadores (mestrandos, doutorandos, pesquisadores de pós-doc, orientadores, grupos de pesquisa etc.). Cada uma das 15 afirmações também podiam ser comentadas, em caso de concordância ou não. O resultado segue abaixo, compondo um mapa valioso de como a pesquisa do artista acontece hoje nas universidades brasileiras, num panorama que ainda está por ser feito, pois o que se esboça aqui é apenas o início de uma necessária pesquisa. Primeiro são apresentadas as 15 afirmações enviadas e, na sequência, a participação de cada um dos artistas, mantendo apenas os pontos assinalados ou comentados.

$\underline{\text { Pesquisa do artista na universidade brasileira }}$

$\rightarrow$ PARTE 1 - Averiguação sobre a relação entre produção artística e produção de texto nas pesquisas artísticas desenvolvidas no programa de pós-graduação que você atua.

( ) 1 - Não são aceitas pesquisas ou defesas de produções artísticas (exposições, obras de arte, criações, trajetórias, projetos artísticos etc.)

( ) 2 - Privilegia-se o texto escrito (documentação, reflexão escrita). A produção artística, se fizer parte da pesquisa, tem importância menor.

( ) 3 - Os métodos da pesquisa artística/ em arte são próximos ou semelhantes aos utilizados pela História da Arte ou por outras disciplinas que fazem leitura da obra de arte, como Filosofia, Sociologia, Estudos Culturais etc.

( ) 4 - As pesquisas, dissertações e/ou teses giram em torno de conceitos ou reflexões sobre a trajetória do próprio artista.

( ) 5 - As pesquisas, dissertações e/ou teses propõem conceitos ou reflexões para obras futuras.

( ) 6 - As pesquisas, dissertações e/ou teses não fazem diferenciação entre produção artística e produção teórica: ambas têm a mesma importância.

( ) 7 - As pesquisas resultam em produções artísticas, acompanhadas de documentação ou reflexão escrita, relacionadas com o processo de produção. 
( ) 8 - As pesquisas, dissertações e/ou teses são constituídas apenas de produção artística, apresentadas sem parte escrita ou documentação.

( ) 9 - A pesquisa artística/ em arte possui o status de obra de arte.

( ) 10 - Existem outros tipos de pesquisa, dissertação e/ou tese de artista que não foram mencionados anteriormente.

$\rightarrow$ PARTE 2 - Averiguação sobre o artista-pesquisador através dos circuitos

( ) 11 - Os artistas na universidade são mais artistas-professores do que artistas-pesquisadores.

( ) 12 - A pesquisa do artista na universidade não precisa acontecer necessariamente em um programa de pós-graduação próprio para ele, podendo ocorrer em programas como História da Arte, Arquitetura, Comunicação, Estudos Culturais etc.

( ) 13 - A pesquisa artística/ em arte extravasa a universidade para outros circuitos (galerias de arte, museus, espaços e revistas independentes etc.).

( ) 14 - O artista-pesquisador não é necessariamente um pesquisador universitário.

( ) 15 - O artista-pesquisador sempre está interessado em outros campos do conhecimento.

\section{$\underline{\text { Resposta da artista-pesquisadora Bia Medeiros }}$}

(X) 4 - As pesquisas, dissertações e/ou teses giram em torno de conceitos ou reflexões sobre a trajetória do próprio artista.

(X) 10 - Existem outros tipos de pesquisa, dissertação e/ou tese de artista que não foram mencionados anteriormente.

Tipo misto: teoria e prática

(X) 11 - Os artistas na universidade são mais artistas-professores do que artistas-pesquisadores.

Nas linhas ligadas à produção artística.

(X) 13 - A pesquisa artística/ em arte extravasa a universidade para outros circuitos (galerias de arte, museus, espaços e revistas independentes etc.).

Nas linhas ligadas à produção artística.

(X) 14 - O artista-pesquisador não é necessariamente um pesquisador universitário. 
(X) 15 - O artista-pesquisador sempre está interessado em outros campos do conhecimento.

Muitas vezes

\section{$\underline{\text { Resposta do artista-pesquisador Gilbertto Prado }}$}

(X) 4 - As pesquisas, dissertações e/ou teses giram em torno de conceitos ou reflexões sobre a trajetória do próprio artista.

(X) 5 - As pesquisas, dissertações e/ou teses propõem conceitos ou reflexões para obras futuras.

(X) 7 - As pesquisas resultam em produções artísticas, acompanhadas de documentação ou reflexão escrita, relacionadas com o processo de produção.

(X) 13 - A pesquisa artística/ em arte extravasa a universidade para outros circuitos (galerias de arte, museus, espaços e revistas independentes etc.).

(X) 15 - O artista-pesquisador sempre está interessado em outros campos do conhecimento.

Aqui acho que faltou uma questão a respeito dos grupos de pesquisa. Em alguns campos das artes (artemídia, videoarte, arte e tecnologia etc.), os grupos de pesquisa, pela própria natureza multidisciplinar, são bastante frequentes. A pesquisa é mais relatada como uma atividade de grupo, de partilha de diversos conhecimentos e pessoas; além do aprofundamento da pesquisa individual (também necessária) de uma determinada questão.

\section{$\underline{\text { Resposta do artista-pesquisador Hélio Fervenza }}$}

(X) 4 - As pesquisas, dissertações e/ou teses giram em torno de conceitos ou reflexões sobre a trajetória do próprio artista.

Mais exatamente, no caso do nosso PPGAV, o mais pertinente seria afirmar que "as pesquisas, dissertações e/ou teses giram em torno de conceitos ou reflexões que surgem a partir da produção artística do próprio artista”. É esta produção/reflexão que vai articulando os saberes de outras áreas. O Programa de Pós-Graduação em Artes Visuais da UFRGS - PPGAV é o programa no qual atuo como professor e orientador (mestrado e doutorado). Ele possui duas áreas: História, Teoria e Crítica da Arte e Poéticas Visuais. Oriento em Poéticas Visuais, mas já orientei também dois trabalhos em História, Teoria e Crítica da Arte.

( ) 5 - As pesquisas, dissertações e/ou teses propõem conceitos ou reflexões para obras futuras.

Isso pode ocorrer também numa dissertação ou tese, ou pode estar implícito no tipo de trabalho desenvolvido, mas não é o objetivo. 
(X) 6 - As pesquisas, dissertações e/ou teses não fazem diferenciação entre produção artística e produção teórica: ambas têm a mesma importância.

Numa tese ou dissertação em Poéticas Visuais, a exposição ou exibição pública da produção artística realizada durante o curso é obrigatória no momento da banca final, junto com o trabalho escrito.

(X) 7 - As pesquisas resultam em produções artísticas, acompanhadas de documentação ou reflexão escrita, relacionadas com o processo de produção.

Uma dissertação ou tese em Poéticas Visuais implica uma produção artística e um trabalho escrito. O conjunto deve dar conta da pesquisa desenvolvida na totalidade do processo de trabalho. O termo Poéticas Visuais diz respeito a um estudo sobre a constituição de linguagem artística, e não a um "conteúdo" poético das produções artísticas. A partir do que é produzido regularmente no nosso programa, posso definir então o trabalho escrito como um estudo teórico sobre a constituição da linguagem artística utilizada na produção (seus processos de realização, métodos, a problemática de sua formalização, seus conceitos intrínsecos, suas especificidades e diferenças com outras produções no campo da arte e da cultura visual, suas possíveis relações com outras áreas do saber, ou o uso que faz destas).

\section{( ) 9 - A pesquisa artística/ em arte possui o status de obra de arte.}

No caso das Poéticas Visuais, a atribuição desse status para o conjunto dos trabalhos implicados na pesquisa não é necessária e não é um objetivo. Por um lado, uma parte da pesquisa se encontra nas próprias obras de arte produzidas. Aí, então, pesquisa e arte se confundem. Por outro lado, temos o trabalho escrito, que também poderá eventualmente desenvolver-se como um trabalho artístico, desde que contenha um estudo e uma clara reflexão sobre o processo de constituição das linguagens artísticas utilizadas. Esta possibilidade do texto-obra constitui-se num exercício muito mais difícil de realizar.

\section{(X) 11 - Os artistas na universidade são mais artistas-professores do que} artistas-pesquisadores.

(X) 12 - A pesquisa do artista na universidade não precisa acontecer necessariamente em um programa de pós-graduação próprio para ele, podendo ocorrer em programas como História da Arte, Arquitetura, Comunicação, Estudos Culturais etc.

Pela experiência que tenho, o fato de um artista na universidade procurar outro programa de pós-graduação, na maior parte das vezes, ocorre por motivos mais pragmáticos, e menos pelas necessidades de desenvolvimento próprias à sua produção artística, como: ausência de curso de pós-graduação em Artes Visuais em sua cidade, dificuldade em teorizar a partir da própria obra, dificuldade em fazer um projeto de pesquisa em arte, dificuldade em organizar um portfólio com um conjunto coerente de obras, dificuldade em ingressar no curso devido ao pequeno número de vagas e de orientadores disponíveis, dificuldade em encontrar um orientador que tenha afinidades com o projeto, incompatibilidade com possíveis orientadores. Todos esses exemplos vieram de fatos concretos, de pessoas que conheci. Mas há exceções, é claro, nessa 
opção pela pesquisa em outros programas. Alguns problemas que ocorrem nesse processo é que os outros programas têm também suas especificidades, seus métodos, sua grade de disciplinas e aquilo que eles valorizam ou não, aquilo que eles aceitam ou não como pesquisa e como trabalho final de tese ou dissertação. Alguns programas nem sequer têm disciplinas que tratem especificamente de Arte, dos saberes produzidos por ela, e muito provavelmente não será obrigatória a apresentação da produção artística como trabalho final de tese ou dissertação. Nesse sentido, outro problema que ocorre com frequência diz respeito a teses ou dissertações feitas por artistas em outros programas, que tratam com profundidade algum assunto relacionado à sua produção artística, mas onde não é analisado ou esclarecido como esse assunto se articula ou se encontra na produção artística, que formas ele adquire ou como ele é desenvolvido pelas criações. Assim, tende-se a discutir mais o assunto de forma isolada, a partir do foco da área no qual o trabalho está sendo apresentado, mas sem trazê-lo junto com as obras ou propostas, sem discuti-lo na singularidade de sua manifestação nas obras ou propostas. São pesquisas nas quais o assunto não é desenvolvido de forma intrínseca ao processo de criação.

\section{(X) 13 - A pesquisa artística/ em arte extravasa a universidade para outros circuitos (galerias de arte, museus, espaços e revistas independentes etc.).}

(É fundamental aqui definir de que circuitos se tratam, e quais concepções e práticas são ali relacionadas).

O contrário também pode ser dito. Historicamente, os saberes acumulados pela pesquisa e prática artística fora da universidade extravasaram para dentro dela. Um exemplo disso são os escritos de artista, sobretudo no que há neles de discussão a respeito da sua própria prática. Em relação a isso, a universidade chegou por último. Por outro lado, existem pesquisas em arte muito importantes que ocorrem na universidade, e que no contexto brasileiro possivelmente só poderiam ocorrer ali. Isso é devido, em parte, ao fato de que são propostas que se mostram incompatíveis ou dificilmente conectáveis com as condições de produção e apresentação existentes nas galerias-museus-exposições. A universidade em diferentes momentos acaba então apoiando ou produzindo outros espaços e situações, acaba expandindo sua atuação em arte, em espaços que não são aqueles onde a arte é geralmente apresentada tais como os citados acima. De outra parte, há também pesquisas importantes que poderiam ser vistas nos locais e eventos destinados à arte, mas são dificílimas as possibilidades de acesso às pouquíssimas galerias, museus, centros ou institutos culturais com boas condições de produção e apresentação. No contexto brasileiro, estes poucos lugares e eventos constituem um circuito mainstream e dominante. Para uma população de mais de 200 milhões de pessoas como a nossa, é minúsculo esse espaço de circulação, e para a maioria dos artistas não há acesso. Vemos aqui se reproduzirem os mesmos problemas socioeconômicos, a mesma enorme concentração de renda e poder que encontramos no país como um todo.

\section{(X) 14 - O artista-pesquisador não é necessariamente um pesquisador universitário.}

\section{(X) 15 - O artista-pesquisador sempre está interessado em outros campos do conhecimento.}

Não é uma especificidade do artista. Qualquer conhecimento na área de Humanas 
necessita do conhecimento de outras disciplinas. E provavelmente nas outras áreas ocorra o mesmo.

$\underline{\text { Resposta do artista-pesquisador José Spaniol }}$

(X) 7 - As pesquisas resultam em produções artísticas, acompanhadas de documentação ou reflexão escrita, relacionadas com o processo de produção.

(X) 10 - Existem outros tipos de pesquisa, dissertação e/ou tese de artista que não foram mencionados anteriormente.

Pensava no chamado trabalho equivalente, onde o foco está no trabalho prático, resultando em exposições que exploram meios expressivos diversos, entre eles instalações, obras em site-specific, livros de artista etc. Nesses casos, com frequência o texto é apresentado sob a forma de um memorial circunstanciado, criando analogias entre processo criativo, o trabalho executado e a história da arte.

(X) 13 - A pesquisa artística/ em arte extravasa a universidade para outros circuitos (galerias de arte, museus, espaços e revistas independentes etc.).

(X) 14 - O artista-pesquisador não é necessariamente um pesquisador universitário.

(X) 15 - O artista-pesquisador sempre está interessado em outros campos do conhecimento.

Resposta da artista-pesquisadora Livia Flores

(X) 2 - Privilegia-se o texto escrito (documentação, reflexão escrita). A produção artística, se fizer parte da pesquisa, tem importância menor.

( ) 4 - As pesquisas, dissertações e/ou teses giram em torno de conceitos ou reflexões sobre a trajetória do próprio artista.

Diria: As pesquisas, dissertações e/ou teses trabalham com conceitos ou reflexões e referências artísticas em diálogo com a produção artística do pesquisador.

(X) 5 - As pesquisas, dissertações e/ou teses propõem conceitos ou reflexões para obras futuras.

(X) 6 - As pesquisas, dissertações e/ou teses não fazem diferenciação entre produção artística e produção teórica: ambas têm a mesma importância.

Diria: idealmente ambas têm a mesma importância, embora sejam pesquisas de natureza diversa. 
(X) 7 - As pesquisas resultam em produções artísticas, acompanhadas de documentação ou reflexão escrita, relacionadas com o processo de produção.

(X) 12 - A pesquisa do artista na universidade não precisa acontecer necessariamente em um programa de pós-graduação próprio para ele, podendo ocorrer em programas como História da Arte, Arquitetura, Comunicação, Estudos Culturais etc.

(X) 13 - A pesquisa artística/ em arte extravasa a universidade para outros circuitos (galerias de arte, museus, espaços e revistas independentes etc.).

(X) 14 - O artista-pesquisador não é necessariamente um pesquisador universitário.

(X) 15 - O artista-pesquisador sempre está interessado em outros campos do conhecimento.

Resposta da artista-pesquisadora Mabe Bethônico

( ) 1 - Não são aceitas pesquisas ou defesas de produções artísticas (exposições, obras de arte, criações, trajetórias, projetos artísticos etc.)

Essas produções são parte do processo e resultado do trabalho, de modo indissociável.

(X) 6 - As pesquisas, dissertações e/ou teses não fazem diferenciação entre produção artística e produção teórica: ambas têm a mesma importância.

(X) 7 - As pesquisas resultam em produções artísticas, acompanhadas de documentação ou reflexão escrita, relacionadas com o processo de produção.

Esse formato de trabalho é possível, mas nem todos os projetos se configuram dessa maneira.

( ) 9 - A pesquisa artística/ em arte possui o status de obra de arte.

Uma pesquisa não é uma obra, mas pode ser, dependendo da proposta.

(X) 10 - Existem outros tipos de pesquisa, dissertação e/ou tese de artista que não foram mencionados anteriormente.

(X) 12 - A pesquisa do artista na universidade não precisa acontecer necessariamente em um programa de pós-graduação próprio para ele, podendo ocorrer em programas como História da Arte, Arquitetura, Comunicação, Estudos Culturais etc.

(X) 13 - A pesquisa artística/ em arte extravasa a universidade para outros circuitos (galerias de arte, museus, espaços e revistas independentes etc.).

Pode ser que sim. 
(X) 14 - O artista-pesquisador não é necessariamente um pesquisador universitário.

\section{( ) 15 - O artista-pesquisador sempre está interessado em outros campos do conhecimento.}

Nem todos estão (infelizmente).

$\underline{\text { Resposta do artista-pesquisador Milton Machado }}$

(Preferi fazer comentários abaixo de cada item, de modo a dar espaço para alguma modulação).

\section{( ) 1 - Não são aceitas pesquisas ou defesas de produções artísticas (exposições, obras de arte, criações, trajetórias, projetos artísticos etc.)}

Pesquisa é produção, trabalho em progresso; defesa é finalização e, na melhor das hipóteses, provisória, parcial. A pesquisa não termina com a defesa, tampouco a trajetória profissional de um artista. Na linha em que atuo (Linguagens Visuais, PPGAV-EBA-UFRJ), cada orientador decide como e quais pesquisas orientar. Pessoalmente, evito orientar pesquisas com foco principal no trabalho de produção de objetos de autoria do candidato, embora tal produção deva fazer parte da investigação. Obras, projetos etc. são examinados e discutidos ao longo de todo o curso, de mestrado e doutorado; por exemplo, nos Seminários de Pesquisa em Andamento, que coordenei por cerca de 14 anos, o candidato submete seu trabalho - de produção de objetos e de textos, e com igual peso - ao coletivo.

\section{( ) 2 - Privilegia-se o texto escrito (documentação, reflexão escrita). A produção artística, se fizer parte da pesquisa, tem importância menor.}

A tese ou dissertação é complementada pelo trabalho produzido em ateliê, em geral com uma exposição no âmbito do curso, ou externa. Na defesa de viva-voz, a banca costuma examinar com atenção especial o texto escrito, já que se trata de tese ou dissertação, com exploração, pelo candidato, dos devidos marcos teóricos. Não se trata de avaliar a "qualidade" do "trabalho artístico" do candidato. Não creio que um programa de pós-graduação em Arte deva pretender "qualificar" esta ou aquela produção de artistas pesquisadores, já que se trata de um programa acadêmico, cujas avaliações são de outra natureza. Cursos de mestrado ou doutorado não são lugares para se avaliar produções artísticas visando certificados de conclusão ou diplomas. Em um ambiente de pesquisa em arte, o que se procura é a produção de discursos poéticos, seja por meio de textos ou trabalhos de estúdio. Como essa prática é coletiva e como acontece em um fórum, pode-se dizer que se trata de uma política.

( ) 3 - Os métodos da pesquisa artística/ em arte são próximos ou semelhantes aos utilizados pela História da Arte ou por outras disciplinas que fazem leitura da obra de arte, como Filosofia, Sociologia, Estudos Culturais etc. 
A pesquisa em arte implica a elaboração de métodos particulares, próprios à natureza de cada trabalho. Como não existe (não mais), a meu ver, o que se poderia chamar de uma "natureza da arte" (ou uma sua ontologia, já que não existe nada que seja "próprio" da arte, com exclusividade), cada trabalho (significativo) é um propositor de metodologias. A pesquisa em arte - embora isso possa se aplicar a outros campos demanda uma certa plasticidade: uma metodologia flexível, macia, assistemática, adaptativa, que admita e encoraje a incorporação de quaisquer disciplinas. E de indisciplinas, daquelas que produzem sombras, monstros, máscaras, passos em falso, tropeços. A pesquisa em arte envolve processos de importação e exportação, muitas vezes escusos. Daí a importância dos contrabandos e da violação das fronteiras. As identidades da arte, assim como seus passaportes, são - por sua "imprópria natureza" - inevitavelmente forjadas, falsificadas.

( ) 4 - As pesquisas, dissertações e/ou teses giram em torno de conceitos ou reflexões sobre a trajetória do próprio artista.

Ver comentários acima, perguntas 1 e 2.

\section{( ) 5 - As pesquisas, dissertações e/ou teses propõem conceitos ou reflexões para obras futuras.}

Obras futuras, assim como obras passadas, se alimentam de obras futuras, e vice-versa. Las Meninas, de Velázquez (século XVII), se alimenta de "Las Meninas", de Foucault (século XX), e vice-versa. Le Déjeuner sur l'Herbe, de Manet (século XVIII), se alimenta do Concerto pastoral, de Giorgione (século XVI), e vice-versa. Uns conceituam os outros, outros refletem os uns. São, propriamente, obras, acionando o que chamo de "trabalho do trabalho". Talvez isso se aplique a alguns casos de boas pesquisas acadêmicas, que, diferentemente dos vampiros, produzam reflexões no espelho.

\section{( ) 6 - As pesquisas, dissertações e/ou teses não fazem diferenciação entre produção artística e produção teórica: ambas têm a mesma importância.}

De quais pesquisas, dissertações e/ou teses estamos falando? Em qual instituição, em qual programa? PPGAV? Não há diferença - a não ser como modulações, como intervalos - entre produção artística e produção teórica. Ambas são Produção. Ambas são Trabalho.

O que mais importa é fazer com que a diferenciação produza a diferença, que é o que produz o movimento.

( ) 7 - As pesquisas resultam em produções artísticas, acompanhadas de documentação ou reflexão escrita, relacionadas com o processo de produção.

Não compreendi bem a questão. De qualquer modo, talvez já a tenha respondido.

( ) 8 - As pesquisas, dissertações e/ou teses são constituídas apenas de produção artística, apresentadas sem parte escrita ou documentação.

Idem. 


\section{( ) 9 - A pesquisa artística/em arte possui o status de obra de arte.}

O que seria "status de obra de arte"? Também não estamos bem certos ainda sobre o que seria a "pesquisa artística". Por isso este questionário. Arthur Danto arrisca afirmar, ou reivindicar, que seus livros de crítica de arte constituiriam obras de arte. Nós também: em tempos de Copa do Mundo, todo mundo se arvora em treinador.

( ) 10 - Existem outros tipos de pesquisa, dissertação e/ou tese de artista que não foram mencionados anteriormente.

( ) 11 - Os artistas na universidade são mais artistas-professores do que artistas-pesquisadores.

O que mais importa é fazer com que a diferenciação produza a diferença, que é o que produz o movimento. "Basta que seja interessante” (Donald Judd). Não basta, mas já é um bom começo.

( ) 12 - A pesquisa do artista na universidade não precisa acontecer necessariamente em um programa de pós-graduação próprio para ele, podendo ocorrer em programas como História da Arte, Arquitetura, Comunicação, Estudos Culturais etc.

A universidade é uma espécie de site-specific. A pesquisa do artista não é uma produção site-specific. Site-specific é uma noção do século XX. Situação = sítio + ação. Todo e qualquer lugar pode ser um lugar para arte. Mesmo uma tese ou dissertação. Sim, as múltiplas e variadas trajetórias do artista contemporâneo (sítios) fazem com que ele pegue várias conduções (ações), muitas vezes embarcando em canoas que o levam a um lugar-nenhum. Tudo bem: mesmo uma ilha deserta pode ser um lugar para arte, desde que se pretenda, o quanto antes, habitá-la.

( ) 13 - A pesquisa artística/ em arte extravasa a universidade para outros circuitos (galerias de arte, museus, espaços e revistas independentes etc.).

O próprio termo universidade já denota um extravasamento.

( ) 14 - O artista-pesquisador não é necessariamente um pesquisador universitário.

Se o pesquisador universitário for um artista e se a universidade for uma necessidade...

( ) 15 - O artista-pesquisador sempre está interessado em outros campos do conhecimento.

Onde está Wally?

\section{$\underline{\text { Resposta do artista-pesquisador Milton Sogabe }}$}

( ) 1 - Não são aceitas pesquisas ou defesas de produções artísticas 
Há uma linha de pesquisa denominada "Processos e Procedimentos Artísticos", que envolve pesquisa prático-teórica.

( ) 2 - Privilegia-se o texto escrito (documentação, reflexão escrita). A produção artística, se fizer parte da pesquisa, tem importância menor.

Nessa linha de pesquisa, ambos são complementares, mas há exigência de pesquisa teórica e não apenas memorial descritivo, pois a pós-graduação stricto sensu forma um pesquisador e possível orientador de pesquisas teóricas e teórico-práticas.

( ) 3 - Os métodos da pesquisa artística/ em arte são próximos ou semelhantes aos utilizados pela História da Arte ou por outras disciplinas que fazem leitura da obra de arte, como Filosofia, Sociologia, Estudos Culturais etc.

A pós-graduação em Artes no Brasil tem origem na História. Os métodos de pesquisas científicas são "próximos e semelhantes" em todas as áreas de conhecimento. Com certeza cada área tem suas especificidades. Muitas vezes diferenciam "pesquisa em arte" de "pesquisa sobre arte". A Arte não é a única área de conhecimento que desenvolve "trabalhos práticos".

( ) 4 - As pesquisas, dissertações e/ou teses giram em torno de conceitos ou reflexões sobre a trajetória do próprio artista.

Depende do que se entende por "trajetória do próprio artista". Uma pesquisa envolve conhecimento da reflexão produzida sobre um determinado tema, buscando contribuição para a continuidade do desenvolvimento e construção do conhecimento. $\mathrm{O}$ artista que tem como objeto de estudo sua própria produção, ou sua trajetória, deve saber contextualizar historicamente e conceitualmente, através das conexões de sua produção com o conhecimento existente na área, seja através da História da Arte, das Teorias e Críticas de Arte e de outras produções semelhantes.

\section{( ) 5 - As pesquisas, dissertações e/ou teses propõem conceitos ou reflexões para obras futuras.}

Se uma pesquisa não possibilitar reflexões e uma maior complexificação de visão de mundo, gerando obras mais interessantes, não se configura como pesquisa.

( ) 6 - As pesquisas, dissertações e/ou teses não fazem diferenciação entre produção artística e produção teórica: ambas têm a mesma importância.

Idem questão 2.

( ) 7 - As pesquisas resultam em produções artísticas, acompanhadas de documentação ou reflexão escrita, relacionados com o processo de produção.

Idem questão 1 e 2. Na linha de pesquisa "Processos e Procedimentos Artísticos" são constituídas de obra e reflexão teórica. Necessariamente não está relacionada ao processo de produção, dependendo do objetivo da pesquisa. 


\section{( ) 8 - As pesquisas, dissertações e/ou teses são constituídas apenas de produção artística, que são apresentadas sem parte escrita ou documentação.}

Não há conhecimento de programa de pós-graduação apenas com apresentação de obra. Mesmo os mestrados profissionais solicitam parte teórica. Mesmo um trabalho de conclusão de curso de graduação solicita um texto como parte da pesquisa.

\section{( ) 9 - A pesquisa artística/ em arte possui o status de obra de arte.}

Pesquisa stricto sensu situa-se no campo científico. Obra de arte situa-se no campo poético. Arte e Ciência têm semelhanças e diferenças. Mas arte não é ciência e viceversa. Na produção de obra de arte, fora do contexto acadêmico, podemos dizer que há pesquisa artística, através de materiais e referências conceituais, mas não tem o objetivo e o rigor de uma pesquisa científica.

\section{( ) 10 - Existem outros tipos de pesquisa, dissertação e/ou tese de artista que não foram mencionados anteriormente.}

Considero que há três tipos de pesquisas: teórica, teórico-prática (objeto é um conceito e a obra é um dos elementos constituintes) e prático-teórica (objeto é a própria obra, buscando uma contextualização histórica e conceitual).

\section{( ) 11 - Os artistas na universidade são mais artistas-professores do que artistas-pesquisadores.}

Penso que leu meu texto sobre isso. A história do ensino de arte no Brasil passou por diversas fases. Com o surgimento da pós-graduação em Artes, surgiram outros tipos de professores/artistas. Um curso não contrata artistas, mas sim professores e em cada área de conhecimento, pessoas formadas nessas áreas. As instituições de ensino contratam professores de Matemática, História, Física e Artes entre outros. Professores que atuam na pós-graduação precisam ser, em primeiro lugar, pesquisadores, seja qual for o curso de pós-graduação. Porém sabemos que na academia há artistas que não assumem "profissionalmente" (com formação continuada e atuação) a função de professor ou de pesquisador. É mais que sabido que professor que não pesquisa ministra o mesmo conteúdo o resto da vida, não acompanhando as transformações e reflexões contemporâneas num contexto interdisciplinar.

\section{( ) 12 - A pesquisa do artista na universidade não precisa acontecer necessariamente em um programa de pós-graduação próprio para ele, podendo ocorrer em programas como História da Arte, Arquitetura, Comunicação, Estudos Culturais etc.}

Como mencionado acima, o contexto que vivemos é o interdisciplinar, e da visão sistêmica, onde a área Interdisciplinar na CAPES surge e cresce de forma exponencial. Assim temos não só artistas em todas as áreas, como profissionais de outras áreas nos programas de arte.

( ) 13 - A pesquisa artística/ em arte extravasa a universidade para outros circuitos (galerias de arte, museus, espaços e revistas independentes etc.). 
Depende das formas de extravasamento "para esses outros circuitos". Uma pesquisa, dependendo do objeto de estudo e dos objetivos, com certeza envolve todo o sistema de arte.

\section{( ) 14 - O artista-pesquisador não é necessariamente um pesquisador universitário.}

A definição de pesquisador é ampla em diversos contextos. Um artista que pesquisa materiais e processos é um pesquisador. Nesse sentido todo artista é pesquisador. Temos vários autodidatas em diversas áreas do conhecimento. Porém o termo "artistapesquisador" precisa ser contextualizado para se entender o porquê dessa denominação.

\section{( ) 15 - O artista-pesquisador sempre está interessado em outros campos do conhecimento.}

No mundo atual é impossível um pesquisador, seja da área que for, não fazer conexões com outros campos do conhecimento.

\section{$\underline{\text { Resposta da artista-pesquisadora Raquel Stolf }}$}

\section{( ) 1 - Não são aceitas pesquisas ou defesas de produções artísticas (exposições, obras de arte, criações, trajetórias, projetos artísticos etc.)}

Vide item 6 e 8.

\section{( ) 2 - Privilegia-se o texto escrito (documentação, reflexão escrita). A produção artística, se fizer parte da pesquisa, tem importância menor.}

No PPGAV-UDESC (na Linha de Processos Artísticos Contemporâneos, nas pesquisas por mim orientadas), a pesquisa em Arte só acontece se ocorrer/for desenvolvida alguma produção artística durante o período de pós-graduação (levando-se em conta que se pode pensar/propor a própria tese/dissertação como trabalho de arte).

(X) 4 - As pesquisas, dissertações e/ou teses giram em torno de conceitos ou reflexões sobre a trajetória do próprio artista.

Sim, elas podem incluir também essas possibilidades.

(X) 5 - As pesquisas, dissertações e/ou teses propõem conceitos ou reflexões para obras futuras.

Sim, elas podem incluir também essas possibilidades.

(X) 6 - As pesquisas, dissertações e/ou teses não fazem diferenciação entre produção artística e produção teórica: ambas têm a mesma importância.

No PPGAV-UDESC (na Linha de Processos Artísticos Contemporâneos) propõe-se uma intersecção e interdependência entre produção artística e produção teórica, em que também se pode pensar/propor a própria tese/dissertação como trabalho/projeto artístico. 
(X) 7 - As pesquisas resultam em produções artísticas, acompanhadas de documentação ou reflexão escrita, relacionadas com o processo de produção.

Sim, elas podem incluir também essas possibilidades.

(*) 8 - As pesquisas, dissertações e/ou teses são constituídas apenas de produção artística, apresentadas sem parte escrita ou documentação.

Levando-se em conta que se pode pensar/propor a própria tese/dissertação como trabalho/projeto artístico (no PPGAV-UDESC, na Linha de Processos Artísticos Contemporâneos), em que a "parte escrita ou documentação" pode vir a constituir um trabalho artístico, eu poderia assinalar/incluir também esse item.

(X) 9 - A pesquisa artística/em arte possui o status de obra de arte.

Sim, ela pode possuir o "status de obra de arte".

\section{( ) 11 - Os artistas na universidade são mais artistas-professores do que artistas-pesquisadores.}

Penso que são ambos, em que cada uma dessas atuações retroalimenta e catalisa a outra: artista-pesquisador-professor.

(X) 12 - A pesquisa do artista na universidade não precisa acontecer necessariamente em um programa de pós-graduação próprio para ele, podendo ocorrer em programas como História da Arte, Arquitetura, Comunicação, Estudos Culturais etc.

Penso que essa opção pode ser possível, de muitas maneiras e com muitas possibilidades de intersecção, com seus desafios, embates, debates e situações a atravessar. Lembro de uma pesquisa muito instigante, intitulada "Antão, o insone: estudo sobre as relações dialógicas entre a visão e a cegueira", desenvolvida pelo artista-pesquisador-professor Marcelo Coutinho ${ }^{1}$. Lembro de conversarmos e que Marcelo (que foi meu colega de turma de doutorado, na UFRGS, entre 2007 e 2011) apontou algumas dificuldades no processo desta pesquisa, pelo contexto em que a desenvolveu e pela proposta instigante de seu processo de escrita, ao pensar uma mistura entre "dissertação e literatura", numa "fronteira tênue entre ciência e arte", como escreve Marcelo no resumo da dissertação. Seu trabalho foi publicado (numa edição revista) posteriormente (2008) pela Editora Zouk, de Porto Alegre, tendo como autor "Tomé Cravan", com a seguinte sinopse (em sites de livrarias): Publicado originalmente em Portugal apenas em Braille, esta primeira edição brasileira traz a perspicaz e elegante análise de Marcelo Coutinho, estabelecendo um rico diálogo entre obra e crítica. Misto de diário confessional, novela ficcional e ensaio epistemológico sobre as possibilidades de troca entre emissor e receptor. No desenrolar das memórias de Cravan, revelam-se não somente a experiência de convívio que teve entre cegos de nascença, mas, sobretudo, suas indagações sobre a própria cegueira.

${ }^{1}$ Marcelo Farias Coutinho, Antão, o insone: estudo sobre as relações dialógicas entre a visão e a cegueira, Dissertação (Mestrado em Comunicação), Comunicação Social, Universidade Federal de Pernambuco, Recife, 2003. 
(X) 13 - A pesquisa artística/ em arte extravasa a universidade para outros circuitos (galerias de arte, museus, espaços e revistas independentes etc.).

(X) 14 - O artista-pesquisador não é necessariamente um pesquisador universitário.

(X) 15 - O artista-pesquisador sempre está interessado em outros campos do conhecimento.

Resposta da artista-pesquisadora Sylvia Furegatti

(X) 4 - As pesquisas, dissertações e/ou teses giram em torno de conceitos ou reflexões sobre a trajetória do próprio artista.

(X) 5 - As pesquisas, dissertações e/ou teses propõem conceitos ou reflexões para obras futuras.

(X) 7 - As pesquisas resultam em produções artísticas, acompanhadas de documentação ou reflexão escrita, relacionados com o processo de produção.

(X) 9 - A pesquisa artística/ em arte possui o status de obra de arte.

As alternativas assinaladas contextualizam elementos das diferentes linhas do Programa de Pós-graduação em Artes Visuais do IA Unicamp, que define e distingue (atendendo às determinações de área da CAPES) teoria de prática. Assim, é possível afirmar que, uma e outra pesquisa (a teórica, voltada e ou vinculada à História da Arte e suas Teorias, tanto quanto a prática, voltada para o trabalho artístico em curso e ou recente, de autoria própria do candidato) estabelecem-se a partir da importância de sua área e que, ambas, refletem no texto seus processos de conhecimento. Um dos importantes aconselhamentos que é dado aos orientandos da linha da prática artística é para que trabalhe seu texto como se este fosse um de seus trabalhos práticos, ou seja, sem dor ou sofrimento, mas com a mesma responsabilidade e paixão que faz em sua produção. Para tanto, a seleção prevê um cuidado para que os candidatos demonstrem certa maturidade poética e teórica, que bem os qualifique para esta difícil tarefa.

(X) 13 - A pesquisa artística/ em arte extravasa a universidade para outros circuitos (galerias de arte, museus, espaços e revistas independentes etc.).

(X) 14 - O artista-pesquisador não é necessariamente um pesquisador universitário.

A figura do artista-pesquisador é uma realidade nas universidades públicas brasileiras. Entendo que esta distinção imposta nas últimas décadas entre circuito e academia já é datada. Pessoalmente desenvolvo projetos e grupos de pesquisa dedicados a trabalhar e recombinar essa métrica entre escola e circuito. Um deles, sob minha coordenação e vinculado ao $\mathrm{CNPq}$, intitula-se Propostas Artísticas Contemporâneas. Tenho também um artigo, publicado há algum tempo, no qual discuto este ponto em meio a outras 
reflexões sobre a produção e o circuito artístico contemporâneo². Para além da atenção dispensada com as pesquisas de orientandos na pós-graduação, como professora das disciplinas de graduação: Metodologia de Pesquisa em Artes Visuais e Orientação de Projeto Final de Graduação, posso também atestar que a pesquisa artística tem seu discurso próprio, visa à construção de um texto que é bastante distinto da revisão bibliográfica e se insere num tipo de conhecimento tácito. Para tanto nos baseamos nos trabalhos de Ricardo Basbaum ${ }^{3}$ e nos estudos de Jorge Vieira sobre as aproximações entre Arte e Ciência 4 . Não posso atestar que TODO artista pesquisador está SEMPRE interessado em outros campos de conhecimento, mas posso te afirmar que esta é CERTAMENTE minha perspectiva de trabalho.

${ }^{2}$ Sylvia Furegatti, Territorialidades da produção artística contemporânea. In: José Cirillo et at. (org.) Poéticas da criação, E.S. 2012, São Paulo, Intermeios, 2012.

3 Ricardo Basbaum, Além da pureza visual, 2007.

4 Jorge de Albuquerque Vieira, Sobre Arte e Ciência, Youtube, 25 mai. 2012. Disponível em:

<https://www.youtube.com/watch?v=VowU5wr2INo>. Acesso em: 29 ago. 2018. 
251 

ANEXO 2

RB SOBRE A PESQUISA ARTÍSTICA:

NA UNIVERSIDADE,

EM VÁRIOS CIRCUITOS, ASSOCIADA A OUTROS CAMPOS 

Conversa realizada em São Paulo no dia 12 de maio de 2018.

\section{Pesquisa do artista na Universidade}

[VG] A partir dos anos 2000, em alguns países europeus, aumentaram os debates em torno da pesquisa artística, por causa da incorporação das academias de arte no sistema universitário. De forma pioneira, em países como Brasil, Reino Unido e Austrália, entre os anos 1970 e 1980, começou a ser criado um lugar próprio para a pesquisa do artista na universidade. E a história brasileira é muito expressiva. A respeito da sua experiência tanto de artista-professor quanto de artista-pesquisador, como você vê sua própria trajetória em relação a esse contexto maior, já que pode ser incluído nessa movimentação da Arte sobre o conhecimento, a educação e a pesquisa.

[RB] Essa é uma questão importante, que passa meio batido nas discussões gerais. Todo mundo reconhece a importância da universidade, mas não tem uma reflexão mais cuidadosa sobre o que é isso. De fato, acho que a gente vive um momento com muitos artistas trabalhando na universidade, no Brasil inteiro. Você pode mapear e ver que tem assim: Recife, Salvador, João Pessoa, Brasília, Porto Alegre, Curitiba. Quando eu era jovem, era um outro percurso o do jovem artista. Hoje em dia o jovem artista já entra na universidade para fazer mestrado e de repente faz doutorado. É uma iniciação pela universidade. Antigamente não era tanto, isso foi mudando. No Rio [de Janeiro], por exemplo, os artistas todos passavam pelo Parque Lage e não necessariamente pela universidade. De fato, muito jovem, eu fui buscar uma relação com a universidade. Eu já tinha um trabalho como artista, começando nos anos 1980. A partir de 1981, eu já trabalhava com o Alexandre da Costa na Dupla Especializada, já começava meu trabalho individual. Em 1985 resolvi ingressar na especialização lá da PUC [-Rio], no curso do Carlos Zilio. Eu sabia que eu não viveria do mercado de arte. Entendia que, naquela configuração que estava sendo feita, eu não ia ter retorno a curto prazo, porque não estava naquele enclave de artistas que buscaram uma relação direta com o mercado, atendendo a uma demanda, com uma certa aceitação do modo de trabalhar, que era basicamente a questão da pintura. Então, naquele momento - como eu me via enquanto jovem artista e o que eu estava fazendo ali -, eu vi que não ia ter uma recepção, uma relação direta e simples e, portanto, eu tinha que procurar uma maneira de sobreviver. Dar aula de Artes era uma coisa que me interessava. Eu tinha feito Biologia e portanto não poderia fazer nada na universidade se eu não me formasse na área de Artes. Então eu procurei o curso da PUC e fiz a especialização. Era um curso interessante. Você deve saber, o Carlos Zilio é um artista que volta da França com o seu doutorado e quer fazer um curso de formação, o primeiro curso de universidade de História da Arte no Brasil, e são preocupações que a gente vê na geração dele. Quer dizer, nos textos que a gente lê do Ronaldo Brito, do Zilio, do Paulo Sérgio, do Waltercio Caldas, textos do final dos anos 1970, a gente vê uma preocupação que eles têm de construir um circuito de arte público e construir uma história da arte que tenha uma materialidade - do modo como está lá no texto do Paulo Venâncio -, de que não seja uma história da arte meramente psicológica e portanto possa permitir que se pense o trabalho de arte contemporânea sem mistificações, para poder atribuir o correto valor, sem atender aos caprichos do mercado, que acaba distorcendo essas coisas. O Carlos Zilio depois sai da PUC e vai criar a pós-graduação para artistas da EBA. Até então a EBA, escola de Belas Artes, escola de tradição acadêmica, só foi se renovando muito recentemente, a partir de meados dos anos 1990, quando o Zilio entra lá. Ou seja, ele fez isso como um dever, com seu passado de militante político. Ele tem até hoje uma bala na cabeça. Não sei se você sabe, ele foi guerrilheiro, levou um tiro, ficou no hospital. Depois foi para a França. Então, foi quase como uma tarefa a ser executada, 
que é fazer uma formação universitária e compreender isso. E aí achei que ali [na especialização da PUC] tinha um espaço. Eu era muito jovem, 1985, 24 anos, começando o trabalho, mas achei que ali tinha algo a fazer e que era um lugar para complementar a minha formação. Eu já percebia que eu tinha um interesse na escrita, mas ainda não tinha isso muito maturado. Mas, de alguma maneira, intuí que ali era um lugar que eu poderia expandir a minha prática e, uma vez lá dentro, de fato foi um lugar de formação, porque eu me vi com a demanda de escrever e elaborar uma reflexão. Daí fiz um trabalho de especialização sobre a arte dos anos 1980. Eu achei que tinha que falar da minha experiência naquele momento e acho que é um trabalho que tem um certo pioneirismo, porque até hoje a historiografia da arte brasileira não lidou com o período de maneira correta. Tudo isso serviu para ter certeza de que eu tinha que falar sobre o circuito de arte brasileiro, sobre a minha vivência naquele momento, sobre o que legitimava o trabalho dos jovens artistas. Na verdade o trabalho é sobre isso, uma espécie de comentário e de recepção crítica. Foi muito bom ter feito a especialização porque eu acabei decidindo fazer um trabalho que tinha a sua camada de reflexão sobre o próprio processo e sobre como eu me produzia como artista, questões que eu fui ter consciência de modo mais pragmático e metodológico bem mais recentemente. Hoje eu vejo que o meu trabalho também é sobre isso, sobre como a gente se inventa como artista em um local qualquer, no meu caso em um local e um contexto específico, que é o Brasil da abertura política dos anos 1980, início do neoliberalismo, enfim, o contexto de onde eu vim. Eu terminei a especialização em 1988, aí demorei uns três anos. Em 1990, eu acho, comecei a procurar o mestrado. Tentei na USP e não fui aprovado, nem pela Regina Silveira nem pela Carmela Gross, nada contra, mas não me aceitaram lá (risos). Fui tentar na Unicamp, em Multimeios, e também não fui aceito. No Rio não tinha um curso legal de Artes, eu fui buscar a ECO, a Escola de Comunicação [da UFRJ], pois tinha um grupo lá muito interessante, de pensamento contemporâneo. Eu trabalhava no Parque Lage, como organizador de umas palestras, e a gente organizou um ciclo de jovens filósofos, com Henrique Antoun, James Arêas, Ivana Bentes, e com outros que eu não estou lembrando nesse momento. Daí tinha uma coisa deleuziana que eu achei incrível e me senti seduzido, e ali entrei. Fui superbem acolhido. Fiz um texto, que mais uma vez dialogava com o meu processo, e que depois virou um capítulo da minha dissertação, chamado "Migração das palavras para a imagem", e que hoje está naquele livro Além da pureza visual. A gente tinha um grupo chamado Visorama e o pessoal reagiu bem ao texto, sentiu uma ressonância em uma questão que interessava também aos artistas e dialogava com o meu interesse da escrita. Eu já me sentia assediado com a demanda de exercer um papel como escritor ou como crítico - e eu não queria representar esse papel, porque eu me via como artista querendo usar essa ferramenta -, então esse texto tentava dar conta disso. Também era um texto que incorporava algumas primeiras leituras do [Gilles] Deleuze - porque eu cheguei a fazer um grupo de estudos, muito breve, com o Márcio Doctors e a Lygia Pape, para ler o livro de Deleuze sobre o [Michel] Foucault. Eu já tinha ficado bem contente de que o texto da minha monografia da especialização tinha sido publicado na revista Gávea. Depois a Gávea me pediu um segundo texto, e eu mandei esse "Migração das palavras", que foi o texto para entrar no mestrado da ECO. Eu lembro que no comitê de seleção tinha o André Parente e o Rogério Luz, que acolheram superbem o texto, e aí eu entrei. Não era uma pós-graduação em Arte, mas...

[VG] Mas tinha artistas lá?

[RB] Não, nem na PUC tinha artistas. Eu acho que fui um dos primeiros artistas a fazer o curso da PUC, depois outros passaram por lá, mas quando eu fiz não tinha muitos, porque era um curso de História da Arte e Arquitetura no Brasil, embora tivesse o Zilio 
como professor, o Ronaldo Brito como professor, assisti a algumas aulas com o Paulo Sérgio Duarte também, Thomaz Brum, enfim...

[VG] Mas então não existia um lugar específico para artista no Rio de Janeiro como já havia em São Paulo?

[RB] Não, não havia. Eu acho que não havia. A Escola de Belas Artes tinha, eu acho, uma pós-graduação em Arte e Antropologia. Se alguns artistas passaram por ali eu não sei, mas não é o que a gente reconhece hoje como pesquisa em arte. Podia ter até alguns casos ali, mas não era, de fato. O Zilio, quando vai para a Escola de Belas Artes, vai criar isso lá no Rio.

[VG] E aí você teve uma experiência fora do Brasil...

[RB] Pois é, foi engraçado, porque eu entrei na ECO em 1992, estava lá fazendo mestrado e apareceu uma bolsa do British Council para artistas. Me inscrevi para um ano, passei e aí tranquei o curso da ECO, e já tinha feito os créditos todos. Fui para Londres, fiquei um ano, fiz o que eles chamam MA full time. Eu escrevi um texto para esse MA, um texto sobre diagramas, que também tinha tido uma boa acolhida lá...

[VG] É o mesmo que está no livro Além da pureza visual?

[RB] Exato, é um capítulo. Aí, quando eu voltei, traduzi e incorporei esse texto, escrevi talvez mais dois capítulos e fechei a dissertação.

[VG] Em Londres existia um ambiente de pesquisa artística ou pesquisa em arte?

[RB] Eu entrei no curso do Goldsmiths, que naquele momento estava um pouco na moda, porque tinham passado por ali Damien Hirst, os YBAs [Young British Artists], vindo da graduação. Então minha experiência foi muito curiosa e, por outro lado, muito decepcionante, porque eu já tinha noção do que era um mestrado no Brasil, que ainda era de quatro anos. Eu já me sentia maduro e já pesquisando algo que tinha a ver com o meu trabalho. Achei que a tônica do curso não era ver o trabalho como pesquisa, mas como um espaço de produção e de ateliê. O trabalho seria criticado por mentores, e isso seria uma plataforma de inserção no circuito. Como era a época dos YBAs, isso significava um assédio muito grande do mercado, porque era o período do neoliberalismo inglês com tudo, e aí os jovens artistas eram mercadoria ali tinindo. $\mathrm{O}$ que se dizia é que o [Charles] Saatchi podia entrar no seu ateliê a qualquer momento e comprar tudo, havia esse mito. Os mentores, os professores que organizavam as studios visit, exigiam que você produzisse, e eles não entendiam a minha posição, que eu não produzia como meus colegas. E eu já não via o meu trabalho causando esse apetite todo para o mercado. Então eu conheci o Guy Brett - que me acolheu bem -, e tentou me inserir um pouco nessa tradição brasileira daqueles que têm obras participativas. $O$ Guy Brett simboliza para mim a sua relação com o Hélio [Oiticica] e a Lygia [Clark]. Todas as observações que os mentores faziam sobre o meu trabalho eram totalmente tolas, nada aproveitável - inclusive eu entrei em pequenos conflitos lá, nada muito grande -, e foi quando entendi que o curso era uma coisa meio boba de criar uma pressão para que você mudasse o seu trabalho e ficasse produzindo. Daí eu pensei: "Não, isso aí é ridículo, não tem pesquisa nenhuma, não tem compreensão de pesquisa”. Naquele momento estavam começando os PhD por lá, e o Milton Machado, por minha influência ou porque ele me conhecia, acaba indo para lá. No ano que eu ainda estava lá, 1994, ele chega para começar um doutorado no Goldsmiths. 
[VG] Mas com uma característica mais de ateliê ou mais teórica?

[RB] Eu acho que eram as duas coisas, mas o Milton, pelo feedback que ele me dava, sofria muito, pelo que ele via também como uma certa incompreensão. Aí eu já não sei se é... só você falando com ele para entender o que ele quer dizer com isso. Mas eu acho que havia sim um espaço de estúdio, já era uma tentativa de abrir um espaço de estúdio, e eu sei que na Europa isso é uma coisa tardia comparada com o Brasil, porque não viam a razão de um artista fazer doutorado, em geral. Achavam que o doutorado não era para artista, que o doutorado não sei o quê... enfim, realmente o Brasil é pioneiro nesse aspecto. Mas, então, quando eu volto do Goldsmiths, eu volto já tendo descoberto a questão do diagrama, que vem resolver o meu dilema, que me levou ao mestrado, que é esse conflito entre a escrita e o trabalho. E o que eu chamo projeto NBP é exatamente sobre isso. Eu lembro que um colega, na época, comentava brincando: "Não, esse seu mestrado é uma espécie de caixa verde [do Marcel Duchamp]". Ele via a relação daquilo com o meu trabalho como se fosse o grande vidro e a caixa verde, o que eu acho que ainda é o paradigma da pesquisa em arte hoje. De fato, o que eu entendo como projeto NBP, tal como é formalizado no meu mestrado, muito influenciado pelo Deleuze e Foucault, pela teoria dos enunciados de Foucault, pela arte conceitual, é esse trabalho duplo sobre como articular a questão da escrita e a questão plástica. De modo que a questão plástica não fique submissa à autoridade do logos, vamos dizer assim, e que caminhe junto com a questão plástica. Eu vejo que essa é, até hoje, a minha questão. Eu fui me constituindo como artista, realmente, aproveitando o espaço da universidade para construir o meu processo de trabalho, embora, paradoxalmente, nada disso você vai encontrar registrado em projetos encaminhados para as agências de fomento. Até hoje eu não formulei a minha prática como um projeto de pesquisa modelo, de um formato a ser submetido a um fomento. Porque eu também tenho muito receio - eu como um professor, funcionário da universidade, dezoito anos na UERJ e agora na UFF -, um receio de ser devorado pela burocracia da universidade. Então, é o tempo inteiro um jogo de estar dentro e fora. É uma loucura, porque eu vejo isso como um exercício de fato constante, de difícil conjugação...

[VG] Você nunca teve um apoio de pesquisa?

[RB] Bom, no mestrado tive uma bolsa da CAPES, mas...

[VG] Eu digo na universidade, como um professor-pesquisador.

[RB] Não, nunca pedi. Não sou pesquisador do CNPq.

[VG] De produtividade...

[RB] Não estou na ANPAP. Já andei pela ANPAP. Há três anos eu falei: "Eu quero entrar na ANPAP", e pediram tanto material para me candidatar que desisti. Enfim, mas o que acontece é um paradoxo. Toda a minha pesquisa na universidade, que eu doo à universidade, que eu considero que está lá, mas que a universidade não vê, porque não está mapeado, tudo isso foi construído com verbas que eu mesmo consegui. Para as minhas viagens ao exterior, eu busquei as passagens com as instituições que me apoiaram. De modo geral, produzi o trabalho com verbas das instituições que me convidaram. 
[VG] Para a universidade você era só um artista-professor?

[RB] Ou até um professor, porque na UERJ eu entrei no departamento de História da Arte. Eu era um artista do departamento de História da Arte, nem estava no departamento de Linguagens Artísticas, que é onde estão os artistas. Hoje o jovem artista sai da graduação para o mestrado e já faz doutorado, às vezes termina com 30, 30 e poucos anos já com doutorado, vai fazer um concurso. Eu não, eu adquiri o valor do meu trabalho através do circuito. Acho que as agências de fomento têm que compreender casos como o meu, e já nos lançarem numa plataforma de pesquisadores de artes com certo percurso. Mas se eu entrar nesse processo, vão me considerar um pesquisador inicial. Isso às vezes me dá uma preguiça. Mas agora que eu entrei na UFF, estou pensando em experimentar isso, encarar esse mundo dos editais, tentar virar pesquisador do CNPq - sei lá para quê, mas talvez possa ser interessante. Mas há um déficit aí, esse mundo... é o que eu escrevo naquele texto "O artista como pesquisador". São dois mundos, o mundo da arte e o da universidade, cada um é um universo, com seus sistemas de avaliação e valoração. O sistema da universidade de valoração passa pela produção, pelas agências de fomento, currículo Lattes. Se você for ver o meu projeto de pesquisa cadastrado na universidade, na pós-graduação, é um projeto de pesquisa guarda-chuva, que me permite fazer tudo o que eu faço, me permite fazer o meu trabalho como artista, me permite fazer crítica institucional, me permite tudo, mas eu acho que a qualquer momento vou ter que pegar um dos meus projetos, Você gostaria de participar de uma pesquisa artística?, por exemplo, e redigir um projeto CNPq com esse nome. Mas sei lá, são mundos que não se comunicam tão facilmente.

[VG] No texto "O artista como pesquisador", de 2006, você via um "momento favorável para a área de artes na universidade", imaginando uma "ação possível - e potente" para os artistas contemporâneos a partir da universidade. Para você, qual é a situação dos artistas-pesquisadores hoje?

[RB] Então, eu percebi melhoras. Por exemplo, na UERJ, quando eu era professor, o Instituto de Artes atuou para que os mecanismos de valoração interna da pesquisa incluíssem exposições, incluíssem e reconhecessem a atuação do artista, para que uma exposição individual tivesse tanto peso quanto um livro. Então, isso tudo foi melhorado, e reconheço que houve melhoras por atuação nossa e de outras pessoas. A FAPERJ, lá no Rio, abriu um edital específico para Artes, durante vários anos seguidos. Agora, talvez tenha uma questão aí que é diferente da Europa e dos EUA, uma questão muito básica. Vivemos em um país com a economia difícil, em geral, e o mercado de arte é muito atrelado à economia real de cada país. No Brasil, toda essa distorção de distribuição de renda incide também no mercado de artes. Então, é uma economia da arte muito limitada, não tem instituições com verbas para adquirir obras, para fazer acervos públicos. Só existe, praticamente, diálogo com o colecionismo privado. O fato de muitos artistas do Brasil irem para a universidade é porque não tem outro modo de viver que não seja entrando na universidade. Lá é um lugar que pode ter uma acolhida, de fato. Eu acho que a área da pesquisa em arte no Brasil melhorou muito. Os artistas vão para a universidade e vão procurando melhorar aquele ambiente. Eu posso nomear pessoas que eu conheço, fora as que eu não conheço, e universidades nesses lugares todos... eu conheço gente em Rondônia, no Amapá, em João Pessoa, Recife, Salvador, Vitória, Rio de Janeiro, Belo Horizonte, Brasília, Curitiba, Florianópolis, Porto Alegre, artistas atuantes. Isso deve querer dizer alguma coisa. 


\section{Sobre Projeto Matéria}

[VG] Na minha tese, eu utilizo Projeto Matéria de Jorge Menna Barreto para fazer a passagem do artista-professor para o artista-pesquisador, porque é uma obra de arte que transforma o espaço expositivo em sala de aula e foi desenvolvida durante a pesquisa de mestrado dele. Queria que você me contasse um pouco sobre a sua participação.

[RB] O que me chamou atenção ali - quer dizer, eu lembro menos do que foi a minha aula, mas lembro do que eu gostei e de que me senti acolhido - foi que ele fez uma coisa que eu chamo de generosa, que foi exatamente incorporar no espaço da exposição esse modo de atuação. É como se eu não precisasse mais ficar tão dividido entre o mundo do trabalho como professor na universidade e o mundo do circuito. É como se ele tivesse feito com menos conflitos. Eu percebi que ali eu não precisava sair de um papel para o outro, porque eu vi que ele tinha uma clareza sobre esse deslocamento e talvez menos conflitos sobre esses dois papéis. E abriu um espaço ali que eu me senti imediatamente acolhido e me identifiquei. Essa é a minha sensação aberta, digo ampla. Que ano foi?

[VG] Foi 2004.

[RB] Então... aí eu propus o artista-professor, porque escrevi aquele texto "O artista etc." em 2003. Foi o momento em que eu tomei um pouco mais de consciência sobre esse processo de autoprodução como artista. Eu propus esse tema porque estava mergulhado nesse problema, de como a gente se pensa como artista.

[VG] Eu imagino que tinha a ver também com a própria proposição do Projeto Matéria, de ser uma sala de aula dentro da área expositiva do Centro Cultural São Paulo.

[RB] Claro. Exatamente. Olha só, tem uma coisa muito importante que eu penso a partir da minha prática e que fui me dar conta recentemente, quando tive que fazer um memorial para um concurso em 2015, um memorial de toda a vida, aquela loucura que você faz. Antes de entrar na universidade, eu dei aulas no Parque Lage e dei muitas aulas nos chamados festivais, que eram muito populares naquele momento [anos 1990] no Brasil, como o Festival de Inverno de Ouro Preto, Festival de Verão de Nova Almeida, Festival de Diamantina, de Goiânia, Brasília, Porto Alegre. Em um certo momento foram muito importantes para mim esses festivais, porque aconteciam as oficinas. O que é uma oficina? É você estar com um grupo ali e pensar uma atividade conjunta. Eu desenvolvi uma metodologia para desenvolver obras a partir das oficinas, que são os tais dos jogos "eu-você" [eu-você: coreografias, jogos e exercícios]. Eu fiz, por exemplo, com o Jorge um desses jogos na EXO [espaço EXO Experimental Org, como umas das aulas de Projeto Matéria], e me chamou. Fiz também no Festival de Nova Almeida. Um projeto que eu faço atualmente, das conversas-coletivas, passa por essas oficinas. Eu nem preciso usar esse nome "conversas-coletivas"; eu uso porque é como é identificado, mas é isso, um workshop, uma oficina. E aí eu percebo que o meu trabalho depende de uma situação e de um método, que é alguma coisa anterior à aula. O meu entendimento de aula é anterior a essa aula formalizada. Ou seja, estar junto, conversando, pensando junto, fazendo alguma coisa junto, discutindo um texto, ouvindo e falando, que é a situação da oficina ou workshop. A aula formalizada está na escola e na universidade, mas a aula formalizada vem desse lugar, desse encontro. Antes de ter escola, ou universidade, tinha isso: as pessoas juntas conversando e tentando pensar, em um processo de escuta e fala. Então eu percebo que, quando estou em sala de aula, estou em um lugar extremamente formalizado, [com] vários protocolos 
da instituição, para fazer alguma coisa que eu faço na oficina, que é estar junto, conversando, trocando.

[VG] Mas existe alguma diferença entre os dois momentos, fora os protocolos?

[RB] A principal diferença, eu diria, são os protocolos. Se eu estou desenvolvendo um curso na universidade, aquilo vai ter que durar quatro meses, tem lista de presença, tem nota, avaliação, trabalho e não sei mais o quê.

[VG] Mas a conversa em si pode ser a mesma?

[RB] A conversa, eu tento que seja a mesma. É claro que não é a mesma, por conta dessas demandas todas.

[VG] Também têm os protocolos que você mesmo criou para as conversas-coletivas.

[RB] Claro, sem dúvida. Porque evidentemente tudo é atravessado por protocolos, mas pode haver o desejo de construção de um território saudável. Mas eu me vejo muito sensível aos protocolos institucionais. Pode ter a ver com o meu momento de formação, de ser adolescente na ditadura, e com as escolas que eu passei, não sei. Mas eu me vejo muito sensível a qualquer desses procedimentos. "Começa", "fecha a porta", "está atrasado", "não entra", "entra”, "chamar a lista de presença”, "você não veio ontem", "veio hoje", entendeu? São coisas que me assombram até hoje. Quer dizer, evidentemente eu já tenho uma prática de que isso não vai me atrapalhar, mas eu sempre penso: "Poxa, tem que olhar essa lista aqui...”. É claro que eu sei que para os alunos ficarem quietos na sala tenho que fazer uma chamada, essas coisas que você sabe. Da mesma maneira que eu acho que o meu trabalho, em relação ao circuito, me orienta via crítica institucional, para uma sensibilidade em relação à instituição, ao cubo branco, à fala do curador, enfim à expografia, tudo isso que a gente sabe que nos envolve na constituição de um trabalho. Se eu estou na Bienal, eu sei perfeitamente que existe ali um protocolo grande; se eu estou em um espaço independente, é outra coisa. Mas também na universidade eu me vejo muito sensível a isso tudo, à reunião de departamento, a tudo isso, você sabe...

\section{Fenômeno da Pesquisa Artística em vários circuitos}

[VG] Lá fora você publicou no maHKUzine, no Art\&Research e no Afterall. Você participou de exposições coletivas como Counter-Production, ocorrida na Generali Foundation, em Viena, em 2012, ao lado de Henrik Olesen, Marion von Osten, Seth Price, entre outros, e também na exposição Nameless Science, em 2008, que teve a curadoria de Henk Slager, um dos curadores que tentam expandir a ideia de pesquisa artística para além da universidade. Você criou projetos dentro de espaços independentes de pesquisa artística como CASCO de Utrecht em 2008, no Bulegoa z/b de Bilbao em 2014; duas vezes no The Showroom de Londres, em 2013 com o reprojecting (london), e em 2010 dentro do projeto Communal Knowledge de Emily Pethick, entre outros espaços. Queria saber se você se imagina fazendo parte de um fenômeno recente da pesquisa artística (não só na universidade, mas a partir do projeto poético do artista também). Como isso era falado ou pensado nos lugares por onde você expunha ou publicava?

[RB] Você mencionou muitas coisas, que têm suas diferenças. Claro, o Henk Slager, de fato, me chamou primeiro para a Bienal de Xangai e depois para a Nameless Science. 
Essa Nameless Science foi muito interessante porque foi uma pequena exposição em Nova York sobre essa questão do PhD em Arte. Tinha lá alguns artistas que ainda estavam terminando seus doutorados, e eu tinha acabado de finalizar. Depois teve um pequeno simpósio na Cooper Union, com pessoas de vários programas, nos EUA e outros da Europa, com uma discussão sobre isso. Eu lembro que fiz um comentário que era assim, no debate: "Quando será que a Tate vai comprar a primeira tese de artista?". Porque o doutorado de artista acaba se encaminhando para que a tese seja obra, uma obra-tese, para que não se esgote na brochura encadernada. Ao mesmo tempo, eu vejo uma peculiaridade na minha relação com isso, para o bem e para o mal, vamos dizer assim. Eu desenvolvi uma relação com esses universos do circuito de arte da universidade, porque me interessa a questão da produção de pensamento. Essa é uma expressão que eu uso no meu trabalho, desde o início do projeto NBP: a questão da produção de pensamento. O trabalho tem que ter essa questão, esse engajamento. Então eu fui desenvolvendo a minha poética a partir de questões como essas, manejando com cuidado: a construção da linguagem, a maneira como eu desenvolvo os projetos, como vou desenvolvendo a metodologia do trabalho. Mas isso atrelado à poética do trabalho, sem fazer concessão aos protocolos da universidade, mais diretamente falando. Só o Henk Slager pode falar isso para você, mas a minha impressão é que ele queria ter visto no meu trabalho mais protocolos da questão da pesquisa em arte, do modo como ele vê a pesquisa em arte. Tudo que eu estou falando pode ser uma construção subjetiva, mas é a minha impressão. Eu acho que ele não viu elementos suficientes para satisfazê-lo, reconhecer no meu trabalho de fato uma pesquisa em arte, embora eu tenha participado desses eventos todos. Mas depois não mantive um contato com ele, eu não sei, eu tenho essa dúvida. Será? Tudo isso eu coloco como pergunta. Por outro lado, eu via que alguns artistas não tinham essas questões tão claras em suas obras, mas tinham essas questões claras na maneira como costuram sua relação com a universidade. Ou seja, trabalhos que, de fato, desenvolvem um projeto de pesquisa, com os protocolos mais reconhecidamente identificados como pesquisa em arte. Por causa dessa falta de elaboração do meu trabalho junto aos protocolos da pesquisa acadêmica, porque meu trabalho não está elaborado nessa demanda da agência de fomento, e porque não sou um pesquisador formalmente reconhecido como tal, sou apenas um artista na universidade. Uma parte dos que formalizam a questão da pesquisa em arte não vê no meu trabalho pesquisa, porque eu não adentro o território, plenamente, dos protocolos necessários para que aquilo seja identificável. Mas eu vejo essas questões na prática do meu trabalho, mais do que em outros artistas, porque o meu trabalho investe na produção de pensamento e porque ele reconhece, na sua metodologia, um passo anterior à formalização disso na aula, ou no que seja. Claro que isso me dá um lastro para perfeitamente amanhã fazer um projeto qualquer e apresentar, mas não fiz até hoje. Veja só, essa fala é para tentar mostrar um ponto imponderável. Porque, a rigor, eu acredito que a pesquisa em arte na universidade é produção de problema, e que a universidade não é o lugar da arte, o lugar da arte é na sociedade. A universidade pode desenvolver um aparelho de pensamento e reflexão sobre aquilo. $\mathrm{O}$ trabalho tem que ter um enfrentamento com tudo isso, ele sempre vai guardar uma resistência à formalização, em termos do projeto de pesquisa. Então você citou aí uma série de situações, por exemplo, o CASCO e o The Showroom. Quando eu fiz os projetos nesses lugares foi sob a direção de Emily Pethick, que por acaso acabou de ir para a Rijksakademie, em Amsterdã. Então, de fato, ela é alguém que tem um interesse na questão da educação, no sentido aberto da palavra, que entende a obra de arte não como produção de mercadoria, que entende o circuito de arte no seu sentido mais aberto e entende a obra como pesquisa, em alguma medida. Então não é uma coincidência eu ter trabalhado com ela, nesses dois lugares. O Henk tem um interesse específico na pesquisa em arte. Mas esses encontros não são casuais. 
Eu acho que reconhecem no meu trabalho esse lugar, não só da pesquisa, da relação da arte com o campo da educação, um lugar em que muitas vezes sou colocado. Muitas exposições em que eu participei fui convidado mais pelo chamado educativo do que pela curadoria. E aí, nesses casos, eu me revoltei um pouco. Porque eu acho que é uma divisão falsa ou errada, esse antagonismo não existe. Eu não quero que meu trabalho seja colocado no nicho educativo, eu acho que não deve existir esse nicho. Para mim essas questões da educação ou da pesquisa, eu tento, na medida do possível, trazê-las para dentro da construção de linguagem, do dispositivo que é o meu trabalho. Que a poética tenha essas questões, que não sejam questões que eu tenha que pegar a poética do trabalho e "agora vamos fazer dela um trabalho de pesquisa na universidade". Porque eu vejo isso acontecendo com muitos artistas. E claro que, para qualquer artista, a obra é pesquisa, sempre será pesquisa. Investigação é pesquisa, mas para alguns artistas, quando isso dialoga com o campo da pesquisa universitária, ou com o campo da educação, é como se ele tivesse que sair do trabalho, entender essas questões da pesquisa e da educação, e ver como o trabalho pode conversar com isso e resolver o projeto. O meu esforço é para que essas questões façam parte da minha poética, que o objeto Você gostaria...?, por exemplo, faça a pessoa falar, e que essa fala seja tida como produção de pensamento. Isso está no registro da poética do trabalho e não do projeto de pesquisa. Claro que eu não quero reduzir, nem quero generalizar de uma maneira simplista, ou simplória, no sentido de "desidentificar" todas as nuances que essas questões trazem e as muitas abordagens e enfoques que esses dois pontos podem ter com os diversos métodos, com os diversos artistas e suas diversas poéticas. Aí, então, por exemplo, como eu te disse, eu já participei de alguns projetos: na Bienal do Mercosul, um projeto em Córdoba, na Argentina, chamado Afuera! Arte en espacio público, e também de um workshop no MoMA, em que fui convidado pelos respectivos setores educativos. E não fiquei satisfeito. Porque eu vi que, no cômputo institucional de cada um dos eventos, o educativo é visto como menor, em uma outra região de valor. Como se o que se produz ali não fosse o trabalho, não tivesse o status da obra, tivesse o status de uma outra coisa, que portanto não merecia ser acolhida pela exposição. Eu já vivenciei três situações em que esse conflito aconteceu. Mas eu vejo o meu trabalho como obra que desperta interesse do setor educativo, porque dentro da metodologia do trabalho essas questões estão envolvidas.

\section{Sobre o funcionamento de Você gostaria de participar de uma experiência artística?}

[VG] Eu queria fazer uma pergunta prática sobre o próprio objeto de Você gostaria...? Lá no começo, qual era a logística para o objeto ser enviado? Eu imagino que antes da documenta 12 havia uma logística, e depois outra. De forma bem objetiva, como se dá? Correio?

[RB] É variável. Tem realmente um aspecto prático, tem que ser pragmático. Não tem um fundo de capital nesse projeto que me permita amanhã colocar numa caixa e botar em um avião e mandar para a Coreia, não tem esse dinheiro. Quando ele começa, começa em uma movimentação pequena. Talvez ele tenha ido do Rio para Vitória de caminhão, em uma caixa, eu acho, não lembro mais, ou em um avião... pode ter sido um avião...

[VG] Ou uma transportadora...

[RB] Ou uma transportadora. E eu paguei, provavelmente. Aí ele volta para o Rio, depois foi para Brasília. Quando ele foi para Brasília, eu lembro de ir no aeroporto 
botar em um avião. Foi para essa exposição em Brasília, e aí ele fica por lá, vai para Goiânia, e de Goiânia já vai para Belo Horizonte. E eu vim saber [disso] depois, aí percebi: "Bom, já estamos em um outro momento do projeto". As pessoas foram se organizando por si próprias. De Belo Horizonte foi para Porto Alegre, depois Florianópolis...

[VG] Você nem sabe como foi levado?

[RB] Não sei, porque aí eu percebi a fase dois, ou seja, ele está entrando em redes que já existem. Sendo prático, aconteceu isso. Com a documenta [12] havia dinheiro de transporte... a documenta tinha uma conta de FedEx. Depois Nova York.

[VG] Instituições...

[RB] Instituições, exatamente. Aparece um convite de Nova York, de uma instituição. "Vocês podem pagar o transporte Londres-Nova York?" É feita uma cotação: "Podemos!", e é assim que vai. Eu tenho que aproveitar esses eventos institucionais. O projeto vai parar no Canadá, como? Ele estava em Nova York, alguém colocou no carro e levou para Chicago. De Chicago a Audain Gallery pagou o transporte para Vancouver, e depois pagou para o México.

[VG] E você sabe qual o paradeiro hoje?

[RB] Então... por que eu não tenho o paradeiro? Às vezes eu tenho, às vezes não tenho. É uma opção. Qual opção? O Você gostaria...? tem muita demanda. Eu poderia me dedicar só a esse projeto e não fazer mais nada, mas eu não quero fazer isso. Várias demandas. Demandas de colocar material no site, escrever para a pessoa que não mandou as fotos para o site... Ver onde está esse objeto, mover esse objeto. "Ó, tem um em Joinville que está parado, onde é que a gente vai... para onde vou mandar? Vou escrever a tal pessoa... você quer receber?” Eu poderia fazer só isso na minha vida, organizar arquivo, transcrever entrevista, entrevistar tal pessoa. Tem muito material, entrevista. Poderia só fazer isso, ou seja, gerenciar o projeto. É um trabalho que poderia ser full time, mas eu nunca quis fazer isso full time porque mudaria completamente a natureza do projeto. Eu teria que criar uma empresa, uma equipe, ter assistentes. Isso poderia ganhar uma cara, eventualmente, de eficiência que eu não queria. Tem momentos em que eu não posso me dedicar ou não tenho tempo. Também cai naqueles momentos em que eu não tenho aquele interesse todo. Isso faz com que tenha uma temporalidade muito variável. Tem vazios imensos, mas tem momentos que eu volto a ativar o projeto. Bom, de 1994 para cá tem várias fases, o projeto vai se institucionalizando, vai gerando arquivo, vai demandando um interesse institucional. Em 2010 eu comecei a desenhar um contrato, para me relacionar com instituições. Fiz uma minuta, com uma advogada, começo a perceber a necessidade de encontrar um local.

[VG] Mas esse contrato é para quê?

[RB] Porque eu começo a perceber que, embora minha saúde seja perfeita no momento, o tempo de vida do artista não é infinito. Eu sempre falo desse projeto como podendo acontecer daqui a cem anos, porque é um múltiplo, que é feito da mesma maneira toda vez, e sei lá se em 2080 um grupo de jovens artistas, ou não tão jovens, queira fazer aquele objeto, ou um museu, ou um pesquisador, sei lá. E também o que eu vou fazer com esse banco de dados, com essa memória... 
[VG] E nem tudo está exposto...

[RB] Não, está numa caixa, tem muito material. Como eu protejo para a comercialização, eu não quero que isso seja vendido para um colecionador privado ou para um museu x ou museu y, não quero que isso aconteça. Mas eu aceito que esse museu tenha o direito de mexer com isso durante certo tempo. Houve um momento, em 2010, que o MAR [Museu de Arte do Rio] pediu o objeto. Eles ficaram [com ele] cerca de dois anos, fizeram coisas, fizeram educativo. Antes disso, eu já estava ciente dessa necessidade. $\mathrm{O}$ que eu faço se determinado museu me convidar, o que eu vou fazer com isso? Eu não quero que aquele objeto fique parado ali e intocado. Ele tem que sair, tem que entrar. Alguém [pode], se quiser, cortar ao meio, amassar, entendeu? Não pode a museografia dizer: "Não toque, não toque". Então como eu garanto isso?

[VG] Mesmo para aqueles que não são originais, entre aspas?

[RB] Não tem original. Eu posso fazer uma peça nova amanhã, ela é igual à de ontem.

[VG] Mas os que circularam nesse período...

[RB] Estão circulando né? Alguns...

[VG] Os que estão circulando, que foram feitos por você...

[RB] Não tem diferença. A priori não tem diferença, é um múltiplo. Eles são feitos com o mesmo material. Evidentemente tudo pode ser fetichizado, tudo pode. Então, sabendo disso, eu começo a pensar no contrato. Não para o participante, porque a relação com o participante é uma relação de confiança, é de apertar a mão, e eu não posso botar um contrato no meio do caminho porque um contrato acaba com a confiança. Contrato é um instrumento que serve só quando você não tem confiança. E eu não confio no diretor do museu. Mas por que eu não confio? Porque ele trabalha quatro anos, sai e muda a direção do museu, muda a política do museu, eu não sei para onde vai. Então você não tem como confiar no CNPJ, vamos dizer assim... Eu não posso me sujeitar a que outro diretor fale: "Não, agora ninguém mexe mais nesse objeto, isso é intocável”, não posso. Então, seguindo a tradição dos contratos de artistas, comecei a desenhar um contrato em que a instituição entraria como participante, mas com regras, do tipo: "São dois anos no máximo que esse objeto fica aí", "o museu não é dono de nenhum material que é produzido, ele não é dono do objeto". Aliás, tudo ficaria sempre como propriedade do projeto Você gostaria...? Se há uma dúvida, a gente faria uma reunião em que teria um membro do museu e dois membros do projeto Você gostaria...?, ou seja, estaria em maioria para dirimir uma dúvida... coisas desse tipo. Então comecei a desenhar o contrato. Também há um histórico de adequação entre obras e instituições. A obra nunca cabe na instituição. $O$ famoso exemplo é o trabalho do Joseph Kosuth, Uma e três cadeiras. Quando chega no MoMA, a cadeira vai para o departamento de escultura, a fotografia vai para o departamento de fotografia, e cadê o trabalho? Então, a gente fica pensando como o trabalho vai se encaixar na instituição. Por que a gente não poderia começar a pensar em uma instituição a partir do trabalho? Isso está lá no diagrama: vamos desenhar a instituição que você gostaria, como seria essa instituição? São questões que o trabalho começa a abrir. Ontem eu tive uma reunião para a atualização do site, finalmente vou conseguir renovar o site, porque ele já está arcaico em termos de linguagem de programação. É um site duro, é um site que não responde mais, então a gente vai fazer isso. Na documenta tinha uma estrutura [de 
metal], com uma porta trancada com cadeado, onde ficava o objeto e ninguém podia tirar. Porque a minha ideia era que ficasse um contraste muito claro entre o objeto preso dentro da exposição e os outros objetos andando pelo mundo. Aquela estrutura era a maneira que eu encontrei de mediar a minha relação com a documenta. Eu não poderia só montar uma documentação ali, eu tinha que ter algo que fosse o meu gesto de mediação com a documenta. É um aparato expográfico: lá dentro tinha três monitores de cada lado, um com slideshow, documentação fotográfica, outro com acesso ao site e outro com um circuito fechado. Depois uma versão menor foi feita aqui no Itaú Cultural. A versão da documenta foi destruída; a do Itaú Cultural foi destruída. Não dá para guardar, são negócios gigantes, e depois podem ser reconstruídos. No Europalia eu fiz uma outra estrutura, que tinha um basculante que guardava a peça dentro. Não sei se você viu na Pinacoteca em 2012, em uma exposição do Guy Brett. Na verdade é uma estrutura dessas que eu faço, e debaixo de uma das camas tem um basculante, em que esse objeto entra. Então a exposição inaugura, e o objeto está lá. No dia seguinte, a portinha abre, o objeto sai do museu e vai circular. As fotos vão entrando nas paredes da sala, a partir de um diagrama desenhado especialmente para isso, e vai sendo completado. Depois, na semana seguinte, o objeto volta para o museu. Fica ali guardado... sai de novo. Seria uma maneira de mediar a relação com o museu, o objeto entra e sai. Não tinha como guardar, acabei doando essa estrutura para o museu Dragão do Mar, em Fortaleza. Em janeiro [de 2018] o diretor de lá, o Bitu Cassundé, disse "Quero mostrar, em março". Estava lá, acabou de fechar a exposição.

\section{Interesse dos artistas associado a outros campos do conhecimento}

[VG] Eu percebi que, no desenvolvimento do seu projeto poético, parece haver uma transformação de interesse em relação aos campos do conhecimento. No começo, havia um interesse maior sobre os campos da comunicação, da semiótica e das teorias da linguagem, e isso vai se complexificando através da pesquisa para um interesse a respeito dos estudos do corpo, da subjetividade e de outros saberes. Eu gostaria que você falasse sobre essa percepção.

[RB] Acho que, dos campos que você citou, de fato, o meu trabalho possui um diálogo [com eles]. Talvez, no período de formação, eu tenha me relacionado mais com o campo dos estudos propriamente artísticos: História da Arte, Crítica, Teoria da Arte. Mas à medida que o trabalho vai ganhando mais corpo, isso se torna insuficiente. Você tem que abrir regiões de contato com outros campos, é quase que imperativo. Eu acho que o campo da Arte não dá conta, só ele. A gente pode trazer todos os prefixos: pósdisciplinar, interdisciplinar, transdisciplinar, extradisciplinar. Mas o campo da Arte garante que aquele objeto a que você diz "é uma obra" tenha uma atenção através de uma apropriação por outras disciplinas. Aquilo vira um trabalho, em um gesto duchampiano. Isso aqui é um objeto e não é utilitário, não se esgota na utilidade, não se esgota no uso, não é só um objeto de culto ou de ritual, tem uma economia própria. Mas isso não é suficiente, você tem que fazer conexões com outros campos. Então, de fato, em um primeiro momento eu reconheci meu trabalho conversando com o campo da Comunicação; formulo o projeto NBP numa conversa com o campo da Comunicação. Isso para mim era assumido: "Bom, isso tem que entrar no ritmo da percepção da sociedade de consumo". Ou "tem que entrar no ritmo das imagens, da pósmodernidade", como diria [Jean] Baudrillard naquele momento. Aquilo é um objeto de rápida percepção, aquelas ferramentas das avenidas da comunicação. Ou reconhecer a questão dos corpos. Reconhecer o lugar na filosofia, via Deleuze, [Félix] Guattari, Foucault. É muito frutífero para qualquer artista. Porque se ficar só no âmbito da discussão do campo da Arte, tem um limite aí. Recentemente comecei a querer voltar 
um pouco para esses textos que eu abandonei um pouco. Isso é até uma questão que eu uso nos meus cursos. Eu acho que o artista tem uma licença - o artista ou o pensador, porque eu vejo essa chave do artista como um intelectual, um pensador - , da mesma maneira que a gente pode falar que o poeta tem uma licença de escrita, ele pode quebrar as regras da gramática etc., as normas no campo literário. O artista tem uma licença de leitura, podendo ler qualquer coisa, os textos dos mais diversos campos. Mas tem que saber como se apropriar de certas questões e fazer com que sejam desenvolvidas metodologias para lidar com esses conceitos dos outros campos. O meu trabalho conversa com questões da Biologia também, a questão do vírus. Questões de percepções, talvez. A questão dos corpos, claro, o meu trabalho tem uma marca da performance também, isso é uma questão da obra de arte contemporânea. Acho que você não resolve as questões que o trabalho coloca se ficar só no âmbito da disciplina do campo da Arte. Tem que conversar com outros saberes, mas com um questionamento de como fazer. Porque a arte não pode se tornar um objeto de estudo desses outros saberes, apenas, tem que guardar uma opacidade, a arte tem que provocar esses outros saberes. Enquanto você falava, eu lembrei de uma passagem de um livro do Deleuze e do Guattari, $O$ que é a filosofia?, onde eles tentam fazer aquele modelo de relação dos três saberes, da Filosofia, da Ciência e do campo da Arte, mantendo os três saberes, cada um autônomo em relação ao outro. Eles se colocam no campo da Filosofia, é claro, mas dizem: "Eu preciso da Ciência e da Arte". Deleuze em outro momento fala que alguém como [Jean-Luc] Godard pensa através do cinema, faz filosofia através do cinema. Quando eu fiz uma exposição em 2014 na Laura Alvim, lá no Rio, a Ana Linnemann, uma artista com quem eu tenho uma conversa, falou: "Ah, engraçado, vendo o seu trabalho eu me lembro do Godard". Quer dizer, não estou comparando meu trabalho ao Godard, mas quando o Deleuze fala isso do Godard, eu me identifico com isso, quer dizer, eu penso através do meu trabalho. A meu ver, as disciplinas são disciplinas em rede, em uma situação de conexão rizomática, ou o que seja, com o campo da Arte olhando para o campo de fora. Então eu me interesso muito. As minhas leituras são mais fora do campo da Arte, porque eu acho que o artista tem essa metodologia de leitura. Evidentemente não é só o artista; qualquer pensador, quando está com o seu método de trabalho, consegue se mover pelos outros campos, consegue buscar interesse em outras áreas. Mas eu falo do lugar do artista: então eu me vejo em diálogo com autores diversos, onde a leitura me interessa, e o meu trabalho tentando desenvolver contatos com outros campos, mas sem se tornar um objeto subserviente àquele outro saber. É mais uma questão da inter-relação e da conversa.

\section{Sobre o funcionamento de re-projetando e conversas-coletivas}

[VG] Parece que conversas-coletivas e re-projetando ampliam as questões colocadas por NBP e Você gostaria...? (já bem definidas pelos diagramas e pela tese). A obra de arte fica ainda mais pulverizada, os dispositivos visuais e discursivos da pesquisa ficam mais espalhados, agindo de forma combinatória. Há uma complexidade maior, a percepção e experiência da obra se dão de forma mais esparsa, ocasionando uma participação ou cocriação menos identificável. Elas acentuam, a meu ver e dentro do propósito da minha tese, a questão da pesquisa artística como uma das linhas do seu projeto poético.

[RB] Agradeço a sua acuidade de pergunta. Sério, não estou brincando, não. Porque aonde essa pergunta me leva é de fato um momento muito mais recente da minha prática. São projetos de longa duração. Por exemplo, Você gostaria...? é um projeto que vigora desde 1994, o NBP começou em 1990, 1991. E aí, como eu relaciono essas séries? A maneira como me interessa mais te responder é assim: tentando indicar esse 
movimento interno do método ou do trabalho e como eu me situo ali também - eu poderia responder de uma maneira mais exterior a essas coisas, mas eu respondo mais me vendo do lado de dentro, para pontuar de forma mais particular. NBP começa com um texto, que é uma pergunta: “O que é NBP?”. E Você gostaria...? também é uma pergunta: "Você gostaria de participar de uma experiência artística?”. Eu fiz um texto que se chama "Pergunta dentro de pergunta", em 1996. E também tem uma pergunta que se encontra no diagrama, sobre a suposta transformação possível do objeto, que é assim: "Mas o que vai acontecer com o espectador?", "o que vai acontecer com o artista?”, “o que vai acontecer com o projeto NBP, pode terminar?”. Quando eu comecei a fazer o Você gostaria...?, em 1994, eu pensava: "Bom, esse objeto vai andar, vai acontecer uma experiência, a transformação...”. Então tem também essa pergunta: “O que vai acontecer?”. Quando o re-projetando foi aparecendo, antes do conversascoletivas, ele foi tomando um rumo de um desenho coletivo. Isso eu não tornei muito público, talvez você nem tenha percebido. Foi acontecendo a partir de um reprojetando que eu fiz no México, que eu fiz em Portugal, que eu fiz em Londres, e depois no Rio de Janeiro, lá no [Museu] Bispo do Rosário. Envolve uma maneira de redesenhar aquela forma. Aquela forma vai ganhando outros contornos.

[VG] A forma de NBP vai se alterando?

[RB] O que é o re-projetando? Eu pego essa forma [NBP] e projeto em um mapa. [A partir desse ponto, o artista começa a mostrar imagens de re-projetando em seu celular]. Bom, na experiência do México, em um workshop, eu materializei os ângulos, oito ângulos como peças de madeira. Os jovens participantes do workshop andaram pela cidade com esse desenho, com esse ângulo [de madeira]. Quando a gente foi colocar no mapa o percurso das pessoas, gerou um outro desenho. Quando eu juntei as duas coisas, gerou outro desenho. Em Portugal, igualmente. Em Guimarães, eu propus uma caminhada entre dois lugares. Eu pousei a forma na sala de exposição e no parque, só que é impossível fazer uma linha reta. Não existe esse percurso reto na cidade. Então, na verdade, para vir daqui até aqui a gente teve que fazer assim [o artista mostra o mapa com o NBP projetado], porque tinha uma ponte, uma curva, então esse desenho acabou gerando uma alteração na forma. No re-projetando que eu fiz em Londres, também havia uns ângulos e havia umas caminhadas que os grupos fizeram, que geraram também um outro desenho.

[VG] Eu achei incríveis essas imagens do México, porque eu não conhecia esse objeto [os ângulos de madeira utilizados nas oficinas de re-projetando].

[RB] É, ele nunca... como outras coisas do meu trabalho não chegam exatamente no espaço expositivo muito rápido. Tem artistas [dos quais] todo trabalho acontece nesse lugar. Isso apareceu no nosso workshop no México. Em Londres, no re-projetando, esse ângulo andava pelo Showroom; algumas pessoas usaram e teve umas situações... mas não era um objeto de fato expositivo. Então, por eu ter desenvolvido uma relação, que eu considero, tardia com o mercado de arte, nem todos os meus processos passam pela questão do mercado. Aí eu tenho que ser cuidadoso, porque tenho que ver como isso encontra diálogo com as situações comerciais, e ao mesmo tempo alguns processos tenho que de alguma maneira proteger. Em Você gostaria...?, por exemplo, nada ali é comercializável. Outras questões do meu trabalho são comercializáveis, mas nesse caso eu tenho que ter cuidado. México, Guimarães, Londres... [voltando às imagens do celular]. No México, o desenho dos ângulos gerou uma forma. Em Guimarães, a caminhada gerou um percurso. Em Londres, esses ângulos geraram isso. É claro que eu dou o final desses desenhos, junto com o mapa, mas eu vejo isso como se fosse um 
desenvolvimento de um método, através do re-projetando, de desenho coletivo. Através das ações das pessoas, elas me trouxeram linhas que aí me ajudam a desfazer essa forma [NBP]. Então, como você perguntou, de maneira bem precisa, é claro que o re-projetando já é um processo que se instala na minha prática a posteriori, e quando eu digo: “O que é NBP?", e faço disso uma pergunta, eu estou demandando a um coletivo qualquer ajuda para trabalhar esse desenho.

[VG] Isso é novo, isso nunca foi exibido [desenhos da forma NBP modificada pelo trajeto dos participantes]?

[RB] Não, eu nunca mostrei. Quer dizer, eu fiz uma gravura, talvez, que nunca vendeu, eu acho, que estava na [Galeria] Gentil Carioca. Mas o fato é que nunca houve...

[VG] Mas esses desenhos são de quando?

[RB] Isso aqui surgiu no México, foi em 2010, se eu não me engano. No final do workshop, a gente instalou o desenho em uma área aberta de um edifício, um centro cultural, com fitas adesivas no chão, em que as duas imagens estão superpostas. E daí esse desenho é produzido. Em Guimarães, também, a forma foi acrescentada ao mapa, conectando tanto o Centro Cultural quanto o Parque. Eu coloquei essa linha [do trajeto da ação] no desenho. Em Londres também... havia o diagrama na parede, os ângulos estavam em vermelho, então, depois de duas semanas do projeto, eu disse: "Eu já posso mudar esses ângulos de posição". Fotografei, e aí com os outros mapas que eu fui recebendo, de algumas caminhadas que foram feitas por ali, que me forneceram outras linhas, eu saquei esse desenho. Pode-se dizer que está tudo sob o meu controle? Sim, mas, ao mesmo tempo, é o retorno que eu tive que me permitiu produzir esses novos desenhos. E tem um quarto desenho que foi feito a partir do [Museu] Bispo do Rosário. Só para te mostrar, não sei se você viu essa imagem, de Guimarães [o artista mostra as imagens desses desenhos no celular]. Então, havia esse mapa, e aí depois a gente se deslocou de um lugar para o outro. Na verdade, esse percurso foi feito um pouco a pé, um pouco de carro, tinha chuva, aquelas coisas. Mas um ângulo [da forma NBP, traçado no mapa] estava na sala de exposições, um ângulo estava no ar livre. É claro que tem uma questão de urbanismo aí. Se eu conecto os dois pontos, vou ter uma linha reta. Evidente que essa linha reta não existe atravessando a cidade. Se eu quiser voltar para o hotel em que eu estou, em linha reta, eu vou ter que furar um edifício, é inviável. A gente faz um percurso. Então, é claro que há uma discussão sobre o espaço planejado, o espaço real. Uma certa idealização do que seria a forma, quando ela pousa ali, e a sua desidealização, quando ela toca o solo de fato. É uma discussão que até tem a ver com a própria arquitetura moderna, porque o arquiteto moderno muitas vezes teve essa pretensão de, de fato, destruir tudo isso e trazer essa linha reta. Veja os projetos do Le Corbusier no Rio de Janeiro. São assustadores. Viadutos que ele quer que compitam com as montanhas da cidade. Aquilo é de uma violência brutal. Então isso aqui serve um pouco para essa discussão, de qualquer maneira. Entre essa forma chegando ali, mas sendo desconstruída, quer dizer, perdendo a sua autoridade. Então eu fui percebendo que o re-projetando era uma maneira de ter ações com grupos que implicavam uma desconstrução da forma, que eu sozinho não consigo fazer. Por isso que o que estou te dizendo, voltando um passo atrás, é: “O que é NBP”, uma pergunta, "Você gostaria...", uma pergunta. Ou seja, essas ações todas, na medida em que elas se configuram como perguntas, são maneiras de endereçar ao outro uma pergunta que eu não posso responder sozinho. Eu estou demandando, para a recepção, uma pergunta: "E aí?", "não sei, me ajuda”. Então eu desenvolvo todo esse método de trabalho para que me respondam uma coisa que eu não sei. Ou seja, eu estou atrás do outro para uma 
conversa, “coletiva?”, por exemplo. Eu estou atrás do outro para me ajudar a redesenhar isso aqui. Sozinho eu não consigo me livrar desse desenho, como se esse desenho me obcecasse de alguma maneira, e sozinho eu não vou conseguir nenhuma alteração. Então, de fato, o re-projetando foi caminhando nessa direção, de ser um projeto que fica no limite entre uma coisa curatorial e artística. Ele produz, nessa projeção no mapa, possibilidades de ações e eventos, que aos poucos foram gerando linhas e traços, gerando possibilidades de produção de um desenho coletivo que tem produzido alterações nessa forma. Eu já mapeei quatro modificações. De fato, em reprojetando, eu consigo reconhecer nessa busca de encontro com a recepção, com o público, com o outro, respostas para essas questões. Não são respostas, evidentemente. Mas uma contraposição à pergunta, qualquer. A resposta qualquer. Uma conversa. Daí é que eu vejo a conversa-coletiva como um microcosmos das relações do circuito de arte. O que um artista em geral não tem de conversa com a sua recepção - na medida em que coloca o seu trabalho na exposição e vai embora, e a interlocução se faz a duras penas com o discurso crítico, histórico -, eu junto um grupo e posso ter uma conversa.

\section{[VG] Qualquer conversa?}

[RB] Qualquer conversa. É claro que atravessada pelas questões do meu trabalho, mas não é de uma maneira dura, ou autoritária, ou dominante, mas uma das maneiras de se começar a conversa é trazer questões. "Se a gente está na Bienal, estamos aqui, tem o diagrama, tem esse trabalho...”. Aí começa, mas não para aí. Sobretudo na experiência da Bienal [30 ${ }^{\mathrm{a}}$ Bienal de São Paulo, de 2012], isso ficou muito claro. Foi quando eu tive mais consciência disso. Porque você ouvia aquela conversa-coletiva, parecia o som de quando você andava pela Bienal e ia ouvindo as conversas das pessoas em torno de você, falando da exposição, falando várias coisas da exposição, desde falar sobre as obras a comentários quaisquer. Então, de fato, é também uma maneira, que eu poderia dizer privilegiada, de ter uma conversa direta com uma recepção do meu trabalho. Conversar mesmo, trocar, dialogar, conflitar, falar junto. O trabalho foi mobilizado, foi configurando, foi identificando. Eu gosto de pensar esses dois processos assim. O reprojetando foi se deslocando para esse momento de produção de um desenho coletivo. $\mathrm{E}$ as conversas-coletivas são uma maneira de responder a uma demanda musical que eu tenho no meu trabalho, rítmico-musical: reconhecer na questão da escrita, quando lida, um mecanismo de produção de fala; reconhecer num endereçamento público da escrita o lugar da voz em público, que é um canto; e reconhecer os aspectos de sonoridade deste processo, da escrita, da leitura, da conversa.

[VG] Conversas-coletivas vem desde 2012...

$[\mathrm{RB}]$ Antes.

[VG] Antes? Talvez não com esse nome.

[RB] Não com esse nome, o nome era escritura-fala, mas eu não gostava, então depois eu abandonei. Os dois primeiros foram no México e em Córdoba. Mas no México, por exemplo, o que eu fiz foi gravar em um estúdio textos variados, também ações de cada um, cada um fez o que queria no estúdio. Eu fiz uma colagem, gerou uma coisa longa, de uma hora, um programa de rádio. E em Córdoba eu fiz um livro e um $\mathrm{CD}$, e uma apresentação pública que aconteceu por lá. Mas eu também considero, em virtude do que eu fiz depois, uma situação ainda protótipo, nem é o que mais me agrada. Mas eu fiz, está lá, tem coisas interessantes... Mas, enfim, se eu exercer um juízo meu ali eu 
penso “não, isso não é tão legal quanto os outros”, mas está lá, publicado, trabalho realizado.

\section{Ensaio-ficção e romance-crítico}

[VG] Por último, gostaria de fazer uma pergunta específica sobre dois conceitos que eu encontrei em alguns textos seus, mas que são utilizados em momentos diferentes, até então. Qual a diferença entre o romance-crítico e o ensaio-ficção?

[RB] O ensaio-ficção é um termo que surgiu quando eu estava configurando as tais das tríades do projeto NBP. É um termo foucaultiano. Eu entendo como uma coisa que eu via no Foucault, exatamente para criar um registro da minha escrita que fique, seja na academia, seja fora da academia, reivindicando um status do poético. O ensaio-ficção me permitiria uma escrita que envolve os rigores do ensaio e as aventuras da ficção, vamos dizer assim. Como leitor do Foucault, quando ele fala "tudo que eu fiz nada mais são do que ficções”, e a gente entende porque ele escreve isso, né? Quer dizer, ele está em um embate com uma certa academia também, uma certa metodologia que impediria que ele colocasse o pensamento dele em um registro da urgência do presente. Então ele sabe que, quando se coloca nesse lugar, também está se inventando como sujeito o tempo inteiro, não se deixando capturar. Então, é um termo foucaultiano. O "ficção" está ali para combinar uma escrita que não abdica de um rigor qualquer, não abdica de uma produção conceitual, mas que quer se inscrever em um registro poético da reinvenção contínua. Ele vem em uma dessas tríades, para tentar dar conta do tipo de escrita que eu estou querendo produzir. E o romance-crítico é um termo que surge com o doutorado, surge como um termo para inscrição, que acaba reivindicando um campo no diagrama do Você gostaria...? É um termo bakhtiniano, quando eu fui vendo que o Você gostaria...? é um projeto de pensamento coletivo, um pouco na linha do que eu te disse anteriormente, de ir atrás das pessoas para que elas me tragam. Ou seja, na medida em que eu não estou buscando respostas, evidentemente. Eu estou buscando uma situação dialógica, um jogo dialógico, de uma conversa coletiva. E aí reconhecer que o Você gostaria...?, na escala que ele já está, produz esses comentários e também uma maneira de pensar o projeto. Quer dizer, cada participante pensa o projeto. Não é meramente um participante; esse termo não dá conta, eu não sei qual o termo ainda, participante é uma certa acomodação minha. Mas cada um desses colaboradores, sei lá, tenho que chamar de participantes, mas que é um termo insuficiente, na medida em que manuseia esse objeto, testa os limites do projeto, responde às questões que eu coloco ali, pensa o projeto à sua maneira, produz formulações. Então o que eu teria, nessa constelação de participações, de experiências, seria uma fala coletiva, uma escrita coletiva, daí vem esse romance crítico, na medida em que cada participante aportaria comentários, reflexões, reações ao Você gostaria...? Se a gente olhar o "Diagrama 1", eu me atribuo um papel lá: o papel do artista seria reagir às ações, às experiências, e produzir eventualmente novos trabalhos a partir disso, e ser transformado por isso. $\mathrm{Na}$ medida em que isso se acumula, digo, na medida em que esse projeto vai ganhando um funcionamento, e as experiências vão se seguindo, e que vão se acumulando, eu comecei a me ver como um gerenciador desse projeto, que o meu papel era mantê-lo em aberto, e não fechá-lo. Não dizer "bom, agora tenho respostas", e fechou, acabou. Não. Eu quero manter ainda funcionando, eu quero manter circulando, eu quero manter ele em aberto. E fui vendo que o papel de entender o que eram as respostas não era mais meu. Era desse qualquer expectador. Também o papel da recepção, que vai me olhar ali e vai olhar as respostas e ver em cada uma dessas ações também o trabalho desses realizadores, que também são artistas por si. Eu vi que eu não posso pretender e nem quero mais pretender entender todas essas respostas e lê-las, em busca do que elas 
querem me dizer. Eu comecei a entender que elas não são uma fala mais só comigo. São também perguntas que são devolvidas para mim. Fui esperando outros interesses de leitura disso tudo, me deslocando dessa responsabilidade e me querendo ver organizador desse romance crítico. Alguém que está aí tentando organizar toda essa constelação em uma conversa, que também é coletiva, que é um pensamento coletivo. Esse termo me interessou: romance crítico. A gente pode fazer um paralelo com o ensaio-ficção, romance é a ficção, o crítico é o ensaio, em mais uma chave bakhtiniana, talvez. 
273 

ANEXO 3

JMB SOBRE RESTAURO

AGROECOLÓGICO,

AMIZADE E

PESQUISA ARTÍSTICA 

Conversa realizada em São Paulo no dia 6 de janeiro de 2017.

\section{Pós-doc na Udesc sobre ecologia e site-specific}

[VG] Você fez um pós-doc na Udesc sobre agroecologia e site-specifity. Vasculhei bastante sobre você e esse ponto, mas realmente não achei muita coisa.

[JMB] O pós-doc não precisa resultar em texto, não tem banca. Como estava num departamento de artes, a ideia de finalização está ligada especialmente à minha produção naquele ano, que foi bem vasta. Participei de muitas exposições e também fiz o projeto educativo da Trienal de Sorocaba .

[VG] Foi nessa mesma época?

[JMB] No mesmo ano, 2014. Fiz palestras e publiquei um texto bem descritivo em uma revista. Acho que durante esse ano houve diversos momentos de publicação daquilo que eu vinha pensando, seja a partir de um workshop, de projetos artísticos, ou mesmo do texto. Eu e a Regina Melim, que era responsável por mim no pós-doc, consideramos o Café Educativo, que eu apresentei com a dupla de artistas Bik Van der Pol na Bienal de São Paulo de 2014, como sendo o projeto que sintetizava, digamos, de maneira mais abrangente o que eu vinha pesquisando. Agora me fugiu o subtítulo dele...

\section{[VG] Paladar Cego?}

[JMB] Paladar Cego, é. (risos) Estou de férias ainda... E daí, ali dentro havia a possibilidade de intervenção em um restaurante e de palestras que foram organizadas, nessa integração com o projeto do Bik Van der Pol . Eu acho que ali as coisas ganharam uma maturidade, de anunciação. Então, considero esse projeto como não só uma primeira síntese do que foi o pós-doc, mas também a base do que virou o Restauro mais adiante. Eu acho que o Restauro começa dentro do projeto de pós-doc, e me vejo ainda dentro das mesmas questões, ampliando as questões que surgiram a partir do pós-doc. E o pós-doc era para ter durado dois anos, e acabou sendo abreviado por conta do concurso que eu fiz no Rio em 2015. Então, acabei ficando um ano só. Mudei para o Rio e, enfim, descontinuou. Esse segundo ano seria para fazer uma publicação das coisas que eu pesquisei no pós-doc. Então, acabou não acontecendo esse segundo momento, mas...

[VG] E 2014, a meu ver, foi um ano bem intenso de atividades...

[JMB] Foi. Superintenso.

[VG] Então, esse foi o resultado desse momento do pós-doc.

[JMB] Exato.

[VG] Você pretende fechar?

[JMB] Eu queria fazer uma publicação agora que fosse uma publicação do Restauro. Não seria uma publicação do pós-doc, mas seria uma tentativa de trazer essa dimensão mais textual, reflexiva ou discursiva para um formato que me interessa, isso na minha prática. Um pouco mais desacelerado, talvez, de abordagem. Partir de um processo que seja de leitura mesmo e de um tempo mais dilatado com a obra. Porque eu acho que no 
Restauro abdiquei dessa dimensão, inicialmente. E o que foi uma novidade para mim. Não tinha uma preocupação de inserir a obra a partir de um discurso que ficasse explícito e evidente naquele momento. Então, as pessoas vinham tomar um café, iam embora e não sabiam, ou não ficavam sabendo, que aquilo era uma obra. Acho que, sim, existe um outro tipo de participação, que chamei de participação celular. Então, sim, o corpo dela [da pessoa] participa, seja pelo que esse café tem de informação.

[VG] Ela não precisa saber que está participando.

[JMB] É. E isso para mim é uma novidade na minha trajetória. É isso que eu tenho chamado de participação celular ou mediação celular; o que, eu acho, era coerente no Restauro, com a ideia que eu queria trazer do alimento como protagonista da relação. Entendendo que o alimento é melhor lido pelas células do que de forma discursiva. Mas essa dimensão discursiva da obra é muito grande, tem muita pesquisa envolvida naquele trabalho que não emergiu dali despropositadamente. E entendo que o Restauro, de uma certa maneira, é uma extensão do pós-doc.

[VG] Mas daí o processo de pesquisa de Restauro já não estava mais dentro da academia?

[JMB] Não, não estava na academia.

[VG] Institucionalmente?

[JMB] Não, muito pouco.

[VG] Mas já começou como Restauro?

[JMB] Não, não. Ele ganhou esse nome. A própria ideia de escultura ambiental também nasce a partir do Restauro. Então, eu tenho esse desejo de dar mais visibilidade para essa segunda camada aí que estrutura o Restauro, mas que propositadamente não estava visível na Bienal. Muito pouco era visível. A gente optou por não ter texto, por não ter fotos, foi uma opção mesmo: não nesse momento, nesse projeto, não é esse o momento. E até respeitando um pouco a vocação do lugar, que é um lugar de intervalo dentro da Bienal. Então, não é um lugar de mais estímulo. Estou com isso entalado, eu estou louco para falar sobre isso também. Então, agora, como isso vai se espacializar em uma publicação, ainda não sei.

\section{Sucos Específicos, agroecologia e ser vegano}

[VG] Sucos específicos foi o primeiro projeto que você fez a respeito de agroecologia?

[JMB] Isso, foi a primeira coisa que eu fiz. Na verdade, aconteceu no Café Educativo de 2013, no Museu da Gravura, em Curitiba . Foi a primeira vez, de maneira um pouco acidental, digamos. O museu ficava do lado de uma feirinha orgânica, e eu já tinha esse interesse; então, envolvi a feirinha como fornecedora do Café Educativo. Fazia parte também desse projeto uma oficina, que tinha o título "A Relação entre as práticas sitespecific e a agroecologia”. Isso foi em 2013; e dei essa oficina, por sugestão do Felipe Prando, que era o curador, em uma agrofloresta no norte do Paraná, a Cooperafloresta . Foi o meu primeiro contato... daí pirei com a ideia sobre o que é uma agrofloresta. Isso tudo resultou no pós-doutorado também. Então, tem esse antecedente; não estava superclaro ainda o que era... 
[VG] E o que era antes? O que você tinha feito antes da proposta de agroecologia? Antes disso era o Desleituras?

[JMB] É, no doutorado...

[VG] O último ponto antes dessa participação sua no Campo Neutral foi o Desleituras?

[JMB] É, eu acho que foi. Em 2012 fiz a exposição na Bolsa de Arte, que era dos tapetes, que forraram todo o chão da galeria. Eu acho que sim... Foi no doutorado que surgiram essas questões da agroecologia e de alimentação, que até então eram uma questão pessoal, e fui me interessando. Costumo brincar que eu escrevia com a mão esquerda o doutorado e com a mão direita pesquisava sobre agroecologia, achando que eram coisas separadas.

[VG] Você já era vegano?

[JMB] Eu me tornei em 2011. Foi durante o doutorado, durante a pesquisa. E eu achava que era uma questão minha, uma questão biográfica, e não algo que tivesse relação com o trabalho. É engraçado quando tu escreves o doutorado porque... - e isso para mim é algo que não era o foco da minha pesquisa, não era o meu objeto de pesquisa, mas fazia parte da minha relação com a escrita - eu estava em uma crise muito grande. Entrando nos dados biográficos, eu estava em uma crise muito grande durante o doutorado, querendo largar; estava desanimado, como é frequente. A gente tem os períodos de desânimo. Um amigo me recomendou consultar com uma nutricionista; ao invés de ir ao psiquiatra, fui à nutricionista. E ali começou um processo de auto-observação, de começar a perceber e sair do período de desânimo. Entrei em um período de transformação do corpo, do jeito de entender o alimento. Isso começou dentro do doutorado. Essa solidão profunda que a gente vive no doutorado, no momento da escrita... - especialmente quando eu fui para Porto Alegre escrever, fiquei nove meses em Porto Alegre escrevendo - então, tudo o que você come, tudo o que você faz, acaba impactando a tua produção. É um momento de autoanálise também, grande, o doutorado. Você tira o foco do seu objeto de análise, mas o modo analítico permanece contigo para tudo. Mas eu achei, inicialmente, quando estava escrevendo, que aquilo era mais uma questão pessoal que não vazou para dentro do doutorado como assunto. Assim que eu terminei o doutorado foi para isso que me direcionei. Só que daí, quando caiu a ficha de que o alimento é um dos mediadores principais da relação sociedadeambiente, me dei conta que não estava distante de algo que me interessa, que são as questões da terra, do território, de ocupação de espaço, de uso dos lugares, uso da terra. Daí comecei a encontrar alguns aliados para pensar sobre isso, tanto dentro da discussão sobre agroecologia como em arte também. Por exemplo, revisitando os projetos de Land Art, de intervenção na paisagem; um livro que foi importante também para eu entender isso foi o Undermining, da Lucy Lippard, último livro dela, que eu pesquisei durante o pós-doc. É um pouco sobre pensar as intervenções ambientais como parte de um sistema não só de intervenção intencional na paisagem, mas dos nossos hábitos enquanto sociedade. Eu acho que isso soluciona a questão que ela traz: como o nosso modo de viver, de estar, cria um impacto ambiental e modela a paisagem; então, essa ideia eu trago dela, só que partindo do processo digestivo, da relação com o alimento. 


\section{Sobre artivismo e o coletivo Laranjas}

[VG] Você está falando dessas questões que adentram um campo político. Eu acho que a sua obra antes estava pautada pelo político ou pelo ativismo, mas de forma um pouco mais branda. Talvez agora tenha ficado um pouco mais forte. Os anos 2000 foram de ativismo muito intenso, a partir do Fórum Social de 2001, em Porto Alegre , e um número grande de artistas brasileiros começou a trabalhar sobre questões sociais ou políticas, e você faz parte desse momento. Queria que você contasse um pouco desse percurso dentro do seu trabalho e também da ação feita no Fórum Mundial, em que você tapou buracos, porque não encontrei muita coisa a respeito disso. Nem sei se você considera como uma obra ou se dentro do seu percurso. E como seria essa ponte política até agora?

[JMB] Ah, legal, legal resgatar isso. Eu fazia parte de um coletivo que se chamava Laranjas . Ali, no início da década passada [década de 200o], foi um momento de coletivização, não só em Porto Alegre onde eu morava, mas também em vários lugares do Brasil. Os artistas estavam se juntando para fazer coisas, e que não dependessem necessariamente de um amparo institucional. Um artigo da Juliana Monachesi, que saiu na Folha, buscou mapear alguns desses coletivos ; talvez tenha sido a primeira vez que vi a palavra artivismo. Ela junta arte com ativismo e busca pensar a relação desses coletivos com o âmbito institucional também, e eu também contribuo para esse artigo. Isso foi muito próximo da minha saída de Porto Alegre; comecei a fazer o movimento de sair de Porto Alegre para fazer o mestrado aqui em São Paulo, em 2002. Foi quando eu comecei a fazer umas disciplinas como ouvinte com a Sônia Salzstein. Eu já vinha de uma reflexão, desde a minha graduação, sobre as práticas site-specific. A graduação eu terminei em 1997; então, o trabalho Minha Terra, Sua Terra, por exemplo, que é de 1999, já tinha uma reflexão e uma ideia sobre o lugar, sobre a terra, sobre o chão, a partir de uma condição nômade, uma condição que não é fixa, que eu fui analisar só mais adiante, lá no mestrado . Essa ação no Fórum Mundial foi noturna, onde busquei alguns buracos no trajeto entre a minha casa e onde o Fórum acontecia. Eu fiz uma mistura com gesso cor de laranja...

[VG] Mas junto com os Laranjas?

[JMB] Foi uma ação minha, mas impregnado pelos Laranjas. Foi uma questão que a gente discutiu, o quanto o estado Laranja é um estado molecular. A gente não precisava estar em grupo pra atuar como um Laranja; é a própria ideia de coletivo... Tem um texto que escrevi sobre isso, de 2008, uma reflexão sobre uma exposição na qual os Laranjas participaram no Maria Antônia . Uma ação coletiva reside em um agrupamento de pessoas que são propositoras, mas pode residir também como metodologia de trabalho, com várias pessoas envolvidas. E um trabalho que considero coletivo, apesar de ser feito muitas vezes sozinho, e que uso no texto, é justamente um trabalho da Carla Zaccagnini.

[VG] Que inclusive se chama Restauro.

[JMB] Sim, exatamente. O trabalho do CCSP.

[VG] Não tem nenhuma relação?

[JMB] Com o Restauro da Bienal? É um trabalho que me interessa muito, ele me ocupou; conversei com a Carla a respeito do Restauro. É um trabalho que me habita. 
[VG] Mas não foi uma homenagem direta ou...

[JMB] Não, é um outro jeito de chegar no título... Eu acho que tem algo da relação com a história de ser um restaurante. Tem uma coisa que talvez tenha sido mencionada na banca [de defesa do mestrado de Carla Zaccagnini ] sobre o artista como aquele que faz uma benfeitoria na instituição, uma crítica institucional que vem como uma ajuda, quase, como uma melhoria. Não são palavras adequadas as que estou usando, mas ali tem uma ideia de restauro, que não é da obra Cabeça, do Almeida Junior, mas que é de um restauro do CCSP; é uma prática restaurativa. Eu acho que aí sim tem uma conexão, porque eu entendo que o Restauro presta serviço institucional, ao mesmo tempo que se coloca de maneira crítica ou aponta que ali tem um espaço que está adormecido, que não tem sido pensado dentro, que se constitui como fora, mesmo estando tão dentro arquitetonicamente, espacialmente; mas que também inclui os educadores. Pela primeira vez os educadores e os funcionários da Bienal têm um lugar para comer, porque era algo que não acontecia nos restaurantes anteriores, pelo preço, pela qualidade da comida.

\section{A criação de um restaurante}

[VG] O valor era baixo. Pelo valor do almoço que é cobrado aqui em São Paulo... Isso era subsidiado? Se sustentou?

[JMB] Não era subsidiado, parte da nossa ideia era de que o restaurante fosse sustentável. Era muito importante. Sustentou e até deu um excedente, que a gente pretende usar para fazer a publicação. Tinha umas estratégias; a gente tinha uma economista na equipe. Ela nos ajudou a pensar algumas questões a partir dessa ideia da economia solidária, que era um pouco de poder optar pelo preço. Mesmo o preço mais alto era um preço barato, mesmo 15 reais era barato. A gente tinha, por exemplo, a água, que era 5 reais... o refresco também. Então, a gente tinha produtos que subsidiavam o almoço. Quem tinha grana só para almoçar não entrava nos excedentes. Tinha gente que chegava lá e dizia "ah eu quero tudo" e gastava... sei lá, gastava mais. Então essas pessoas acabavam sustentando ou possibilitando a participação de todo mundo. Não foi um excedente grande; não era um projeto orientado por lucro.

[VG] Você achou delicado fazer um trabalho que tratasse de lucro, de empresa?

[JMB] Achei superdelicado, achei superdifícil isso. É uma novidade total para mim. Pensar em uma participação que envolva economia. E pessoas trabalhando, contratadas. Todos tinham salário; sobre o salário a gente também chegou a uma decisão de que existia uma isonomia, todo mundo era pago com a mesma quantidade, mesma quantia. Era um salário baixo, mas todos ganhavam o mesmo valor, independente do que faziam.

[VG] E como foi essa negociação com a Bienal ou com o curador para que esse comércio acontecesse, porque acabou acontecendo uma obra como comércio.

[JMB] A Bienal nunca colocou isso como um problema. Foi tratado com uma naturalidade que eu até estranhei. A preocupação era mais minha.

[VG] Porque talvez eles teriam que contratar esse trabalho de qualquer jeito, seria feito por alguém. 
[JMB] Sim, seria feito por alguém. Se eu não tivesse reivindicado aquele espaço, aquilo teria sido como sempre foi; vai alguém que não é um artista, que não é uma proposta. $O$ que eu digo é que foi tratada com uma naturalidade mas não é que não tenha sido endereçada. Foi endereçada, mas com muito menos conflito do que eu imaginei. Até porque eu acho que tinha algo que sustentava essa ideia de optar por... em determinado momento eu tive que optar: "será que eu vou fazer um quiosque vegano no terceiro andar, independente do restaurante?”, e daí ser uma opção para a pessoa ir, participar e trabalhar em uma escala outra, em uma escala artesanal, com horários que a gente definiria de atendimento e de cair dentro de uma situação que é mais simbólica, talvez, do que de impacto real. Ou se a gente vai de fato ter uma intervenção, que ela é, no sistema estrutural da Bienal, em um esqueleto da própria fundação, no seu modo de funcionamento, e reverter isso para uma chave que seja de um impacto ambiental positivo. E, logo de saída, a gente se deu conta de que se quisesse trabalhar com insumos agroflorestais e, de fato, ter um impacto importante e significativo nessas redes com quem a gente gostaria de trabalhar, não poderia ir a esses assentamentos e pedir um saco de tomate... A escala também foi ditada pelo tipo de impacto e incentivo que a gente queria nesses nossos fornecedores. E também a dimensão econômica; pensar a dimensão econômica como impacto ambiental. Porque logo nas nossas primeiras visitas às agroflorestas, ficou claro que a forma de impacto que a gente teria nessas famílias seria via economia, via aquisição de produtos. Logo que me convidaram eu manifestei meu desejo de trabalho com a agrofloresta, mas não sabia como.

[VG] Até então você não tinha a ideia de ocupar o espaço do mezanino?

[JMB] Não, isso veio depois. Então, eu fiquei pensando muito no [Robert] Smithson, na ideia de site e non-site, pensando agrofloresta como um lugar remoto e de como trazer isso para Bienal. Então, pensei nas linguagens mais familiares à arte e ao próprio Smithson; em filme, pensei em gravação da paisagem sonora; pensei em texto, pensei em uma publicação. Até que cheguei nessa ideia do alimento como mediador dessa relação. Mais do que pensar em uma ideia de representação da floresta dentro do pavilhão, pensei que o alimento poderia dar conta dessa extensão. De pensar a Bienal como uma extensão da floresta e como parte de um sistema que tanto a agrofloresta alimenta a Bienal, como a Bienal, a partir de uma dimensão econômica, retroalimenta essas famílias que foram as fornecedoras. Então, a dimensão econômica se faz presente por uma necessidade de alimentar esse sistema.

[VG] Algumas coisas tiveram que ser criadas, ou vocês pegaram modelos, de um restaurante vegano, por exemplo?

[JMB] Não, foi tudo criado do zero. Essa rede de agrofloresteiros não existe.

[VG] Esse modelo de negócio. (risos)

[JMB] Não, isso era um desafio até para a escola de ecogastronomia, que era uma das colaboradoras. Elas queriam de fato ter um modelo de negócio que pudesse inspirar outros restaurantes; provar que é viável e próspero. Então, isso era um objetivo delas.

[VG] E tem restaurantes que têm esse mesmo modelo?

[JMB] Não, essa rede de abastecimento não estava pronta, ela foi construída do zero, com todas as dificuldades possíveis de escala, de negociação econômica. Foi todo um processo inaugural; até porque, se for pensar a lógica de uma agrofloresta, não é uma 
lógica de abastecimento de um restaurante. A lógica de abastecimento de restaurante é mais próxima da monocultura do que da agrofloresta.

[VG] Mesmo esses restaurantes que só trabalham com orgânicos?

[JMB] Sim, sim. Eles estão ligados ao Box da Luciana no Ceagesp ; a um tipo de estruturação e uso da terra, que é determinado por receita, por exemplo. Então, essa ideia de que a gente pode ter um restaurante que não tem uma receita fixa, que o alimento é determinado pelo produtor, já que a ideia de agrofloresta é muito mais para autossustentação. Então, a ideia não é de produção em escala. $\mathrm{O}$ alimento produzido é para a família que cultiva ou para o grupo que cultiva aquele espaço; o excedente é trocado com os vizinhos ou comercializado, não é uma prática de escala. E isso para nós foi resolvido - e a gente queria e insistiu que tivesse essa ênfase na agrofloresta -, quando a gente trabalhou com cooperativas. Então, era pego um pouco de cada família para constituir um montante que era necessário para o restaurante.

[VG] Desculpa eu te cortar para falar de uma educadora. No dia em que eu fui almoçar no Restauro, não sei se era proposital ou não, ela veio conversar com uma naturalidade... Ela, na verdade, não veio conversar comigo, especificamente. Tinha mais gente na mesa, e ela abordou as pessoas em uma conversa muito natural. De repente ela começou a falar, e eu fui percebendo que era a mediadora. Achei até que ela estava almoçando junto. Então, imagino que deve ser proposital esse tipo de abordagem.

[JMB] É, foi um trabalho bem intenso para a gente entender qual era a posição desses educadores. A gente tinha duas formas de entender esse trabalho deles. A ideia de ter os educadores no salão foi muito a partir do Café Educativo, então é uma herança do Café Educativo . No Restauro especificamente, a gente pensava que esses educadores eram como enzimas digestivas do processo de elaboração que acontecia ali. Não só uma enzima digestiva do Restauro mas também da exposição. Então, eles fizeram o curso de formação, o que os tornava aptos a conversar sobre a Bienal, entendendo que o restaurante é também um lugar de digestão da Bienal como um todo, e não só das questões propostas pelo Restauro. Então, é um lugar de metabolização do que acontece. Eu acho que isso é uma coisa enfatizada no Café Educativo, o de pensar esse momento do cafezinho como um momento de elaboração daquilo que foi visto ou de metabolização. E, outra, a gente conversava muito sobre isso, não havia algo que o público deveria sair sabendo dali. A obra não precisava ser completada pelo discurso do educador. Se a pessoa saísse sem saber que era uma obra, só quis tomar um café, como exemplo que eu dei, está tudo certo.

[VG] Eu percebi que não tinha educador em todas as mesas. Acho que tive a sorte de cair em um momento em que aconteceu uma mediação.

[JMB] Não tinha uma regra; por conta disso, é um pouco aleatória a atuação deles, e eles também trabalhavam com a recepção das escolas que visitavam. Por isso também eram pagos pela Bienal, porque isso foi uma questão que a gente não completou. As degustações para as escolas eram pagas pela Bienal e fornecidas pelo Restauro. Então, havia, sim, um subsídio pra ter esse acesso das pessoas que ou não podiam fazer uma refeição, porque não podiam pagar nem os 15 [reais] - apesar de ser barato, tem gente que não pode - ou pelo tempo também restrito só ficavam 10, 15 minutos ali. Então, a gente tinha degustações públicas para as escolas. E daí os educadores ajudavam com isso; mas também com público espontâneo. Algo que pautava também a atuação deles, 
algo que a gente conversou, era tentar perceber qual a era fome das pessoas que estavam por ali. A fome foi uma palavra que a gente usou, mas qual era a biodisponibilidade de cada um para uma abordagem mais discursiva? E aí era muito da sensibilidade de cada educador, de chegar e ver o quanto cabe uma conversa e o quanto não cabe, o quanto há de interesse com quem eles estão conversando e quanto que não há. Mas isso era bem importante, de não ter esse conteúdo preparado para delivery.

\section{Sobre a incompreensão da Pesquisa Artística na $32^{\mathbf{a}}$ Bienal de São Paulo}

[VG] Tem uma questão dessa última Bienal [32 ${ }^{\mathrm{a}}$ Bienal de São Paulo] - acho que é uma questão bem complexa, imagine, até de a gente imaginar agora - que foi a incompreensão daqueles trabalhos pelos críticos Aracy Amaral, Sheila Leirner, Rodrigo Naves, geralmente publicadas pelo Estadão. Nessa Bienal ficou muito forte e muito presente a Pesquisa Artística . E ao meu ver essa incompreensão é uma incompreensão também do fenômeno da Pesquisa Artística hoje. Parece que houve uma simplificação dessas novas práticas artísticas e uma visão desses críticos muito reducionista, muito simplista, querendo fazer uma associação dessas práticas novas com as dos anos 1960 e 1970. Queria saber como você vê essa incompreensão. É algo que sempre aconteceu, mas o nome (principalmente na Europa) está sendo definido agora. No Brasil bem antes. O modo como acontece hoje é bem específico, tem um modo diferente.

[JMB] Superlegal essa tua observação, eu não tinha pensado a partir dessa perspectiva da Pesquisa Artística. Acho que coloca alguns desafios para o formato expositivo, mesmo. O que o formato expositivo pode ser? Quais são as qualidades do formato expositivo que dão conta de uma Pesquisa Artística? Considerando que muitos desses trabalhos demandam um tempo de leitura e de aproximação que, às vezes, o formato expositivo não oferece. $\mathrm{O}$ conforto ou o tempo mais dilatado de permanência com a obra. Eu posso te responder, mas a partir do meu caso. Adoraria revisitar agora a Bienal a partir dessa perspectiva que tu colocas. Mas eu acho que ali no caso do Restauro tem essa vantagem, entre aspas, de ser um espaço de permanência. Por mais que as refeições sejam feitas de maneira mais rápida, 15 ou 20 minutos, em uma obra é bastante. Se a gente for pensar que o hábito de visita de uma obra é muito menor, o tempo de permanência em um determinado trabalho, acho que ali no Restauro tinha essa dilatação do tempo que é positiva para entrar em contato com o trabalho que demanda mesmo um pouco mais de envolvimento; para que você acesse o que ali tem de pesquisa. Também pensando nos desafios de expor uma pesquisa. O Restauro começou no pós-doc e a pesquisa é algo contínuo. Na Bienal anterior, teve um recorte possível, que foi o Sucos Específicos e agora tem o Restauro. Como se desse fluxo de rio a gente fizesse um recorte, tirasse isso e trouxesse para uma dimensão de exposição; esse fluxo de rio é constante. A exposição não necessariamente é o objetivo da pesquisa; ela é um momento de visibilidade daquela pesquisa. Então, eu também entendendo que uma publicação seria quase uma itinerância do Restauro para um ambiente impresso, como se a gente fosse itinerar mesmo a obra. Não é uma obra sobre o Restauro.

[VG] Não é uma documentação?

[JMB] Não. Não como eu estou pensando agora. Não gostaria que fosse algo documental, mas algo como uma extensão mesmo. Pensar que isso faz parte de um sistema mais complexo que envolve todos esses agentes: pós-doc, Restauro, os Sucos Específicos etc. A possibilidade de olhar para isso de uma maneira sistêmica; daí se você entende que as pesquisas também são sistêmicas, cada pesquisa de cada artista envolvido, isso demanda também um repertório sobre cada artista, sobre a forma de 
expor e sobre os assuntos traçados. Só a mediação, o catálogo e o ambiente expositivo não dão conta.

[VG] Mas mesmo para um crítico de arte?

[JMB] É, eu acho que é criticável, não é? A Paula Braga faz uma crítica da crítica . Eu tendo a trazer para uma autocrítica também, de pensar: "poxa, mas como criar". A Bienal é um ambiente que dita um tipo de visitação; quer dizer, imagina quantas Bienais a Aracy Amaral já não viu. E tudo isso que ela viu dita a forma como ela vai ver essa Bienal e o que se espera também de uma Bienal; então, eu acho que faz parte de um hábito que a gente adota. Fazer a exposição dentro do pavilhão da Bienal... a gente necessariamente tem que lidar com tudo isso que está construído naquele espaço, que está determinado por aquele espaço, por aquele hábito. Eu acho que o bacana é a gente fazer uma reflexão sobre isso, sobre essas limitações do prédio, as limitações do formato expositivo, fazer uma crítica das estratégias curatoriais e educativas.

\section{Metodologia da amizade}

[VG] Em muitos momentos, a participação que você propõe é de amizade. Às vezes até de amizade eletiva, de afinidades eletivas, de pessoas que possam travar um vínculo de amizade, um vínculo artístico, uma amizade nova ou uma amizade que já vem há muito tempo, se desdobrado no tempo; ou a amizade que acontece só no momento da participação mesmo. Como é essa questão da amizade dentro do seu projeto poético?

[JMB] Eu não sei se eu... Teria que pensar mais sobre isso, eu acho.

[VG] Se você quiser falar alguns pontos onde isso... Ou se isso aconteceu. Talvez seja uma coisa que eu tenha verificado, mas...

[JMB] Sim, sim... É, eu acho que tem algo; tem uma dimensão afetiva. E daí entendendo a ideia de afeto não dessa ideia do emocional, mas da possibilidade de afetar e ser afetado, da possibilidade de estabelecimento de um território de afetações, de troca de afetos que eu acho que é muito talvez da maneira como eu entenda a participação mesmo. Eu acho que existem questões que passam por motivação. Como motivar alguém para participar? Como convocar? Ou seduzir também? Ou capturar? Então, eu entendo isso a partir do campo de afetos; mas uma reflexão que para mim não é algo completamente que eu aplique de forma direta. É um texto do Francisco Ortega, que até foi o [Ricardo] Basbaum que me passou. Ele fala da amizade como uma construção desse campo político que não é o campo familiar. Amizade como possibilidade de manutenção de um campo que é político. A amizade que te daria o distanciamento necessário que é suprimido pelas relações familiares ou pela familiarização das relações: isso de a gente tratar o amigo como um irmão e de, às vezes, suprimir essa distância. Então, ele fala dessa distância que existe na amizade como sendo algo a ser cultivado. Essa dosagem por vezes eu encontro de forma melhor e outras de forma mais... Acho que nem sempre eu consigo que esse território da amizade seja mantido como um território político. Acho que é uma eterna tentativa de estabelecer... Mas que por vezes depende da temporalidade de cada um. No Restauro, foram muitas as respostas que a gente teve do público. Porque eu estava ali atendendo quase que o tempo todo; foi um momento de muita observação, de ver como cada um se relacionava com a proposta. Teve gente que vinha encantada pela comida e dizia assim: "nossa, é verdade, isso aqui é uma obra de arte". Daí olhava para o prato e pensava que a visualidade do prato era o que justificava aquilo ser uma obra. Ou por 
causa da bandejinha, sabe? Tinha esses lances de design e de apelo visual do trabalho que, por vezes, confundiam o público, de trazê-lo para uma dimensão que é mais reconhecível a partir do design ou da gastronomia como arte. Então, isso foi um risco que a gente sentiu, na forma como a gente abordou, e isso foi uma questão que o Jochen [Volz, curador da $32^{\mathrm{a}}$ Bienal] trouxe no início, quando a gente estava pensando nos móveis e em como espacializar isso tudo. Ele falou para a gente ter cuidado para que isso não virasse a arte do trabalho. Então, como que a gente pode ser econômico e enxuto e seco suficiente para que a obra esteja nesse outro lugar que a gente gostaria que ela estivesse? Mas eu acho que isso diz respeito a estratégias de vinculação à obra. $\mathrm{E}$, ali, por ser um restaurante que acolhe todos os públicos, eu achei que era importante a gente lançar mão dessas estratégias, de uma captura que também partisse desse sensorial mais imediato, de ter um prato bem bacana, bem construído. Não acho que tenha sido excessivo nesse sentido, não acho que tenha sido um ambiente artistificado. Mas de não abdicar dessa questão, como já abdiquei em outros trabalhos.

[VG] O design era d'O Grupo Inteiro ? Todo o design?

[JMB] Não, só os móveis. O design foi da própria equipe de design da Bienal.

[VG] Ah é? Que planejou as caixas...

[JMB] É, tudo em colaboração comigo. Meu namorado, que é designer, participou também. A caixinha, o logo, o cartãozinho... tudo foi ideia nossa, que a gente lançou e eles resolviam isso a partir das ferramentas do design. Então, foi um processo de cocriação.

[VG] Esse processo de cocriação... em vários momentos tem vários amigos, que eu imagino que sejam amigos seus, colaborando no trabalho. Sejam amigos novos, que talvez você tenha feito, por exemplo, com as questões da agroecologia e mesmo os artistas que te acompanham desde os Laranjas, por exemplo, desde a época da faculdade, pessoas que desde aquela época duram na sua trajetória como artista também . Eu queria saber se você considera o que eu estou chamando de amizade um método de trabalho artístico. Quando você colabora ou quando outros artistas colaboram com você.

[JMB] Sim... Eu acho bonita essa ideia da amizade. Eu gosto muito de pensar a amizade e também interespécies ou interingredientes. Quando o Smithson, fala aquela frase célebre, e sempre volto para ela, quando ele se refere ao Spiral Jet, dizendo: "Naquele momento, eu ainda não tinha certeza a respeito da forma que meu trabalho iria tomar. Eu pensei em fazer uma ilha com a ajuda de barcos e barcas, mas no final eu deixaria que o site determinasse o que eu construiria" . Então, para mim, nessa frase tem o coração do que são as práticas site-specific, que é essa possibilidade de você retirar o outro - seja o outro quem for, nesse caso era o lago, era um espaço físico - de uma condição de suporte para criar um estado em que ele é colaborativo. Eu passo a colaborar com o espaço. E com isso também eu me coloco em uma posição que é de escuta, que é anterior a minha ação, a minha fala. Eu acho que o bacana nessa tua pergunta, tentando imaginar que talvez essa ideia de metodologia de trabalho passe pela amizade, é entender a amizade dentro de uma perspectiva sobre-humana. No Restauro, por exemplo: uma amizade, um comer em aliança com a natureza ou em aliança com as plantas. Pensar um tipo de uso da terra que é também mais amigável com todas as espécies que ali habitam. Nessa possibilidade de criação de uma rede de afinidades que é baseada na escuta. Eu acho que talvez essa seja uma chave para juntar 
o meu mestrado e o meu doutorado. Se, de uma certa maneira, no doutorado, atualizo o que eu chamei de uma metodologia site-specific para pensar outros autores, de como eu me relaciono com João Cabral [de Melo Neto], de como que me relaciono com Felix Gonzalez-Torres, de como que eu me relaciono com [Hélio] Oiticica, ou com a Lina [Bo Bardi]. Talvez o que se mantenha seja isso, seja uma metodologia de trabalho baseada em vínculos de amizade. No doutorado, eu coloco isso de maneira bem clara, que não são vínculos de adesão à poética alheia, mas que envolvem também confrontos, envolvem fricções, envolvem negociações e até desamizades, se a gente for fazer uma atualização da ideia de Desleituras. Mas eu acho que isso também pode ser uma possibilidade de leitura desse método, pode ser um método de leitura, de ler aqueles que constelam junto comigo... uma geração. Acho que o Rumos foi muito importante para me inserir em uma rede de pessoas. O Rumos foi bem importante; foi onde eu conheci a Graziela Kunsch, o Marcelo Cidade, o Alexandre Vogler, o Ducha, a Cristina Freire, o Fernando Cocchiarale. Eu não criei obras novas, fiz uma extensão do Massa que eu tinha feito em Havana. Então itinerei com o Massa para Fortaleza, Belo Horizonte, São Paulo; a cada cidade, eu somava também os pesos, eu retomava do peso que eu tinha deixado na cidade anterior. O Minha Terra, Sua Terra, na curadoria da Marisa Flórido, eu refiz em Belo Horizonte.

[VG] Esse Rumos 2 especificamente teve uma liberdade muito grande...

[JMB] Muito, muito grande. Trabalho muito próximo de amizade dessas pessoas, tanto dos curadores quanto dos artistas. A gente era enquadrado, e os curadores definiam em quais núcleos que a gente participaria. Então, eu participei do núcleo da Cristina Freire, que era "Arte: sistema e redes". E dentro desse núcleo tinha outros artistas; acho que eram vinte e tantos artistas nesse núcleo. E um núcleo menor, que era o "Sobre(A)ssaltos", da Marisa Flórido. Aí eu estava com a Graziela Kunsch, o Marcelo Cidade, o Vogler, o Ducha e a Carla Linhares.

[VG] Mas você estava falando da amizade que isso foi...

[JMB] É, eu acho que isso foi bem importante. Eu acho que o meu trabalho como educador e como professor passa por aí também. Assim, como construção de contexto, um contexto de atuação, seja pelo fortalecimento das instituições, seja das relações. Eu acho que tenho como referência a minha irmã, a Lia Menna Barreto, que é da década de 1980. Nessa época tinha um tipo de atuação que era mais baseada na figura autoral, com uma assinatura de artista. Para um processo de atuação visto na década de 1990 e 2000, uma geração seguinte, de artistas que já operam em bandos.

[VG] A própria obra acaba sendo feita com a colaboração de outras pessoas...

[JMB] Sim, sim. Sendo que tem exceções. Porque a Ana Tavares, por exemplo, que é da [geração da] década de 1980, também tem uma atuação que é muito "coletivizada". Mas de uma outra maneira, também.

\section{Enterrar o NBP e a amizade com Ricardo Basbaum}

[VG] E você participou também do trabalho do Ricardo Basbaum, enterrando o objeto do NBP . Queria que você contasse um pouco. Acho que foi em 2002; você já tinha amizade com o Ricardo Basbaum. Como se deu essa conexão? 
[JMB] Foi o meu primeiro contato com ele. Ele era curador do Panorama de 2001 e daí visitou o meu ateliê, quando ele estava fazendo pesquisa de curador. E a partir dali eu participava também de um projeto que se chamava "Linha Imaginária”, que também era um coletivo de artistas para o qual desenhei o Minha Terra, Sua Terra. Foi desenhado para participar desse projeto, e acho que foi ali que fizeram esse anúncio do Ricardo, que eu fiquei sabendo do NBP e me inscrevi.

[VG] Ah, era por inscrição...

[JMB] É, era assim: "olha tenho o interesse de receber". E daí apareceu aquele trambolho em casa... (risos)

[VG] E aí você tinha alguma história específica para ter enterrado...

[JMB] É, eu acho que tinha uma vontade de... O meu ateliê em Porto Alegre era em um sítio; era em um lugar rural. Então eu tinha essa proximidade com a terra ali, com o verde. Eu tinha espaço para fazer esse tipo de intervenção. Eu queria fazer um salto de escala na possibilidade de fluxo do NBP. Eu entendia que o NBP fazia um movimento que era na superfície terrestre, digamos, com deslocamentos. E no momento em que eu embuti ele dentro da terra é que ele começou a fazer parte de um fluxo que era planetário. Para pensar que o congelamento dele enquanto fluxo da superfície terrestre o coloca em um outro sistema de circulação. Daí isso era enfatizado pelo fato de terem sido 28 dias que ele ficou enterrado, que é um ciclo lunar. Fazer esse salto de escala em uma ideia de circulação.

[VG] O que me deixou curioso é que é um dos usos mais inusitados do objeto. Lógico que teve algumas coisas bem inusitadas, mas acho que enterrar acaba eliminando o uso...

[JMB] E suspende.

[VG] E suspende e enterra mesmo, como se enterra um morto, por exemplo.

[JMB] É, eu acho que isso é possibilitado também pelo fato de o ateliê ser em um sítio.

[VG] Não somente um morto. Não tem só uma visão negativa; poderia ser uma semente...

[JMB] É, um plantio...

[VG] Um plantio. Poderia crescer alguma coisa daí.

[JMB] É, acho que sim. Quando eu recebi o objeto, não sabia o que ia fazer. E quando eu recebi, tive essa sensação "nossa, esse objeto está cansado", já aconteceu de tudo com ele. E daí tinha um pouco uma coisa de deixa ele descansar, sabe? (risos)

[VG] Muito bom.

[JMB] Engraçado retomar essa imagem. Legal essas tuas perguntas que vão para trabalhos também que não são para mim tão estruturais, tipo esse do Fórum Mundial ou do Basbaum. 
[VG] Que acaba sendo uma obra também.

[JMB] Sim, sim. Para mim são mais periféricos. Nenhum deles é um capítulo da minha dissertação ou da minha tese. Eu acho isso legal.

\section{Artista e ao mesmo tempo pesquisador, teórico, professor}

[VG] Ser um pesquisador no Brasil é extremamente difícil. Falta financiamento adequado à Pesquisa, o processo de o pós-graduando chegar a ser professor universitário é longo e desgastante. De onde vem esse interesse de percorrer a carreira acadêmica? Um doutorado é um acontecimento. São quatro anos; é penoso, envolve questões psicológicas que a gente pode até resolver não necessariamente no psiquiatra (risos)...

[JMB] Na nutricionista...

$[\mathrm{VG}] \mathrm{Na}$ nutricionista...

[JMB] Eu acho que isso diz respeito ao meu entendimento de arte. Acho que essa dimensão que eu chamo de metabólica, ou reflexiva, ela é tão constituinte quanto os outros aspectos estruturais da arte, seja do museu, da sala de exposição, seja da obra material. É a possibilidade de leitura, de deglutição, que se encontra na sala de aula, na universidade ou na biblioteca. São ambientes privilegiados para que você exerça esse momento metabólico. Seja de leitura de outros autores, dos seus pares, seja da história da arte, seja da sua própria produção. É uma coisa que eu ainda não elaborei muito a esse respeito. Me interessa, é algo que me passou já pela cabeça. Eu gosto muito de usar essas metáforas do sistema digestivo, da metabolização, ou elaboração ou reflexivo, como isso que acontece para além do que está visível. No momento em que você engole algo, já não está mais operando no campo da visibilidade, mas de uma outra temporalidade que demora horas e horas para você digerir, para você descompactar aquilo que come, que é um processo de desconstrução e de penetração em uma esfera molecular. Então, se você vir uma maçã e imaginar o que acontece com uma maçã dentro do seu organismo, ela é completamente desmembrada e aberta. Então, eu acho que o processo digestivo é um processo analítico. No momento em que ele parece que desconstrói cada célula, cada organização, cada estrutura, para gerar uma outra coisa e dali extrai energia. E isso já acontece na minha graduação, existem insights importantes, existem construções abstratas ou concretas; me dou conta da fertilidade desse momento educativo, que acontece na universidade, passo a me interessar por isso. E daí quando começo a atuar como artista, em 1997, 1998, é a minha primeira exposição Con-fio, e de repente me dou conta de que eu me torno uma espécie de repetidor de uma metodologia de trabalho que eu aprendo na graduação, que o formato expositivo não me fornece as ferramentas necessárias para que eu questione o próprio método. E eu me dou conta de que um mestrado pode ser, justamente, uma volta para a academia, pode ser justamente um recuo crítico em relação a essa temporalidade louca que é a das exposições, em que você é convidado com três meses, no máximo um ano de antecedência, o quão pouco reflexivo é isso. $\mathrm{E}$, de repente, no mestrado eu tive três anos, quatro se for incluir o meu ano como aluno especial, para pensar um assunto. Em qual outro momento do sistema da arte que a gente tem o privilégio de se dedicar a uma questão por tanto tempo? E descompactar isso. E pensar, e estender, e estirar e... Para mim, esse excesso de metáforas que eu uso do campo digestivo tem uma relação com a antropofagia, com uma forma brasileira ou indígena de construção da identidade. Ela passa pelo sistema digestivo mais do que por uma abordagem 
logocêntrica, de construção dessa identidade. Então, embora isso não seja declarado, para mim é algo que, de uma certa maneira, é como eu também me sinto brasileiro nesse entendimento do processo antropofágico, um processo digestivo. Seja como metáfora, seja como algo concreto. E acho que, sim, esse ambiente acadêmico, para mim, é esse lugar de um recuo crítico, de um recuo digestivo. E, paradoxalmente, é um ambiente muito logocêntrico. Então, não é que eu vou fazer um retiro em algum lugar, que seja de suspensão somente das minhas atividades. Envolve um método - no caso de poéticas, é bem mais flexível - que então possibilita que eu pense um objeto como esse. Eu acho que ele não tem a sua centralidade, acho que ele se utiliza da palavra para pensar, mas eu acho que não é logocêntrico com L maiúsculo. Assim, acho que ele não coloca uma centralidade no discurso. Não como eu sinto. Então, eu acho um privilégio poder ter feito um mestrado, um doutorado, um pós-doc.

[VG] Você acha que o seu trabalho existiria sem?

[JMB] Não, de forma alguma, de forma alguma. Eu não teria conseguido elaborar. Pelo tempo, pelos autores e pelas discussões. Eu acho que tem algo que me dei conta no mestrado, é como a sala de aula se torna o teu ateliê e teu processo se torna público. Então, você passa a incluir todos esses outros discursos de autores, de orientador que lê o seu texto e dos colegas que estão participando junto com você em uma disciplina de metodologia; de repente tu tens uma complexidade de vozes que te traz um estado de presentidade, porque daí você está no mundo mesmo, você está ali trazendo as suas questões íntimas para uma esfera que é pública, de discussão pública. É como eu vejo a sala de aula, uma estância pública.

[VG] Mesmo a pesquisa? Ela é mais solitária...

[JMB] Eu acho que a pesquisa é muito populada pelos autores que você traz. Ela pode ser solitária nesse sentido concreto; a gente está sozinho, mas a gente está o tempo inteiro em diálogo com diversos autores. E o orientador, a princípio, também, é alguém que está com você o tempo inteiro, por mais que, às vezes, não tanto quanto a gente gostaria. Sempre tem uma carência de orientação dos pós-graduandos. Isso me entusiasma, essa energia desse lugar me entusiasma e me preocupa que a gente esteja diante.... às vezes, eu tenho uma sensação de que é um ambiente ameaçado, atualmente, por tantas instâncias e por tantas questões que a gente tem vivido a ponto de eu questionar se é um lugar que eu vá ficar.

[VG] Como terminar a carreira de artista na universidade?

[JMB] É, me pergunto se isso de fato é possível no Brasil hoje, se isso é viável diante de todo o cenário que a gente está. Agora, lá na UERJ, por exemplo, eu ainda não recebi o meu salário de novembro [de 2016]. O Rio está em uma crise absurda. A universidade pública está muito estranha. Então, às vezes eu tenho uma sensação, poxa, de repente, também sou parte de uma geração que teve uma proximidade, uma geração de artistas que teve uma proximidade com a academia, mas eu não sei se isso é um lugar que vá se manter. Tenho essa dúvida, se a gente não está vendo também o nascimento de outras formas de produção, que daí também não têm mais a ver com a minha geração.

[VG] E que passam pela pesquisa?

[JMB] Não acadêmica. Não necessariamente acadêmica. 
[VG] Pode acontecer a pesquisa mas não necessariamente acadêmica?

[JMB] É. Não tão rente à academia. Eu acho que eu tenho, mesmo a Carla, e tantos outros artistas que fizeram mestrado, doutorado... Eu acho que faz parte de uma geração que incluiu a academia de maneira muito determinante nas suas pesquisas. Eu acho fascinante a gente poder ter essa matéria-prima na teoria, nos autores, a forma como se teoriza sobre a aula também.

\section{Projeto Matéria}

[VG]: Só para fechar, acho até que para fechar bem... eu queria voltar um pouco no Projeto Matéria . Você tem capítulos escritos sobre essa obra, tanto na dissertação quanto na tese, mas eu queria fazer algumas perguntas específicas, alguns pontos históricos ou de acontecimento, porque é o tipo de trabalho transitório, em que muitas camadas acabam ficando escondidas. Você diz que se relacionar com o ambiente acadêmico do mestrado foi um dos motivos que te levaram a pensá-lo.

[JMB]: Sim, sim, ele coincide com a minha entrada no mestrado.

[VG]: Queria saber se, fora tudo o que acabamos de conversar sobre o ambiente acadêmico, existem outros pensamentos iniciais, outras motivações, referências mesmo, outros artistas que acabaram acrescentando para o Projeto Matéria.

[JMB]: Eu estava morando com a Grazi [Graziela Kunsch] nessa época. E a Grazi tinha uma prática muito performática; ela vem do teatro, foi professora de teatro, inclusive. Eu não lembro qual foi a exposição que ela fez, uma palestra que era uma aula. Eu não me lembro de detalhes, mas.... Foi alguma ação que ela fez e que me atentou a esse lado performático e uma possível leitura estética da sala de aula. O momento da sala de aula como um acontecimento estético. E aquilo ficou comigo, acho que de uma certa maneira. E, talvez, até mais na aula que a Regina Melin propõe, a sala de aula como espaço de performação, busco trazer isso. A Grazi dá a última aula, a oitava: "Registro, documentação e responsabilidade".

[VG]: As aulas eram dadas por você ou pelos participantes?

[JMB]: As aulas eram dadas pelos participantes.

[VG]: E a sua participação na aula?

[JMB]: Era como facilitador, mediador, dependia da pessoa. A aula do Basbaum foi mais participativa; a aula da Cristina Freire foi mais acadêmica, aí eu simplesmente ouvi. Para a aula da Grazi, a gente pensou juntos. Dependia muito da personalidade de cada um. Eu propus os temas.

[VG]: Para cada um?

[JMB]: Para cada um. Então, fiz essa demanda: "Olha, eu quero uma aula sobre isso".

[VG]: E esses planos de ensino?

[JMB]: Qual tu dizes? 
[VG]: É porque tem uma hora que você fala no texto [da dissertação Lugares moles] que os seus planos de ensino eram afixados na parede...

[JMB]: Ah tá. É que no sistema do CCSP tem uma primeira exposição coletiva, e participam todos os que foram selecionados para aquele ano. Foi na segunda exposição, que seria a exposição individual, que o Projeto Matéria aconteceu. Quando eu propus uma oficina, pensei: o que eu vou expor na primeira, na coletiva? Vou aproveitar para divulgar o curso que vai rolar daqui a não sei quanto tempo. E o que fiz? Foi uma coleção de planos de ensino de artistas que atuam como professores. Então, entrei em contato com uma série de pessoas.

[VG]: Você tem isso ainda?

[JMB]: Eu não sei se eu tenho...

[VG]: Professores?

[JMB]: Artistas-professores, artistas que me interessam pela sua atuação.

[VG]: Você se lembra dos nomes?

[JMB]: Lembro, lembro... Eu lembro da Elida Tessler, da Raquel Garbelotti. Que pena que não botei no mestrado o nome das pessoas que participaram dessa coleção, que responderam à demanda. Mas eu devo ter esses planos de ensino em algum lugar. A Elaine Tedesco... Eu fiz uma chamada aberta e daí apareceram vários. Planos de ensino reais, de disciplinas dadas por artistas, de graduação e pós-graduação.

[VG]: Foram duas exposições?

[JMB]: A primeira é quando eles anunciam todos os artistas que foram selecionados, então tem uma exposição grande, coletiva, é uma espécie de apresentação, "olha, essa é a nossa seleção".

[VG]: Depois tem as individuais...

[JMB]: Durante o ano são três individuais, eu acho. O Projeto Matéria rolou mesmo. Mas na coletiva o que eu apresentei foi essa coleção de planos de ensino, e divulguei o flyer, chamando os alunos, entendeu? Usei essa situação como divulgação do curso que ia ser dado mais adiante, porque já sabia o que ia ser o trabalho.

[VG]: Os alunos, quem eram?

[JMB]: Os alunos se inscreveram...

[VG]: Não eram amigos? Eram pessoas do CCSP?

[JMB]: Não, eram pessoas que se inscreveram por chamada pública.

[VG]: Mas foram pessoas conhecidas participar da aula, que você já conhecia? 
[JMB]: Eu acho que, de conhecido, só a Grazi. Ela também deu uma aula, mas participou de todas. Tinha o Wallace Masuko, a Gabriela Leirias, que depois virou amiga...

[VG]: Ah, você lembra dos nomes.

[JMB]: É, lembro. Agora eu não vou lembrar de todos, mas... Acho que foram em torno de dezoito alunos.

[VG]: E teve a leitura, o acompanhamento crítico da Carla Zaccagnini?

[JMB]: É, teve um certo atrito com a Carla. Eu tinha escrito o texto do trabalho dela no Torreão [Centro Cultural e Residência Artística que funcionou em Porto Alegre entre 1993 e 2009], e quando a gente conversou sobre o Projeto Matéria, ela fazia parte do grupo de críticos; coloquei ela à vontade para fazer um texto crítico de fato, não texto de apresentação. Quando chegou o texto crítico, achei que fazia um desserviço para o trabalho, sabe? Fiz uma contraproposta: "Carla, quem sabe, em vez de a gente escrever esse texto antes do trabalho acontecer, a gente escrevesse depois do trabalho acontecer?”. Em vez de ser um texto de apresentação, ser um texto... O que senti no texto da Carla - também o quanto eu lembro dele - é que estava sendo injusto...

[VG]: Lendo hoje você acha injusto?

[JMB]: Não, hoje não. Eu acho que hoje é uma perspectiva. É uma perspectiva... Um dos desafios do Projeto Matéria é trazer a questão da especificidade de lugar para uma especificidade de público. Uma das críticas que a Carla fazia no texto era ser um trabalho restritivo, em que as pessoas não poderiam participar; que não era para o grande público. Era isso que ela trazia como um julgamento, que para mim feria o cerne do trabalho, porque era justamente sobre isso que eu estava falando. Não é o fato de ele trabalhar a partir de uma perspectiva não quantitativa de público, mas específica, que ele é excludente. E que o fato de a pessoa chegar a uma sala de aula que está montada, por mais que não aconteça a aula no momento em que ela visita a exposição, que isso não deixa de ser uma espécie de participação. Então o texto dela, para mim, feria esses dois momentos: entender que aquelas pessoas eram mais especiais do que um público em geral e que a sala de aula vazia não era uma instalação, não era algo que se pudesse construir algum sentido a partir daquilo. Acho que eu, talvez pelo excesso de admiração que tenho pela Carla, acabei dando um peso maior para o texto, na hora que ele chegou; e, também por estar inseguro em relação ao que eu estava fazendo, dei um peso maior do que ele tinha. Acho que hoje eu deixaria. Se isso acontecesse, se eu pudesse voltar no tempo, acho que não teria entendido que o texto dela precisaria aderir. Especialmente porque eu abri essa possibilidade para ela, de escrever um texto crítico. 

BIBLIOGRAFIA 



\section{Dissertações e Teses}

ALBUQUERQUE, Fernanda Carvalho de. Troca, soma de esforços, atitude crítica e proposição: uma reflexão sobre os coletivos de artistas no Brasil (1995 a 2005). Dissertação (Mestrado em Artes Visuais) - Instituto de Artes da Universidade Federal do Rio Grande do Sul, 2006.

. Práticas artísticas orientadas ao contexto e crítica em âmbito institucional. Tese (Doutorado em Artes Visuais) - Instituto de Artes da Universidade Federal do Rio Grande do Sul, 2015.

ALMEIDA, Catarina. After Artistic Research: What Follows the Establishment and the Realization of the Establishment of the Phenomenon. Tese (Doutorado em Educação Artística) - Faculdade de Belas Artes da Universidade do Porto, 2015.

ALMEIDA, Eduardo Augusto Alves de. Aspectos da estruturação do Self de Lygia Clark: perspectivas críticas. Dissertação (Mestrado em Estética e História da Arte) - Interunidades, Universidade de São Paulo, 2013.

ARCANJO, Edison do Carmo. Amarelinho: uma experiência com arquivos dos Festivais de Verão em Nova Almeida. Dissertação (Mestrado em Artes) - Centro de Artes, Universidade Federal do Espírito Santo, 2013.

BAHIA, Dora Longo. Marcelo do Campo 1969-1975. Dissertação (Mestrado em Poéticas Visuais) - Escola de Comunicações e Artes, Universidade de São Paulo, 2003.

. Do Campo a Cidade. Tese (Doutorado em Poéticas Visuais) - Escola de Comunicações e Artes, Universidade de São Paulo, 2010.

BARRETO, Jorge Menna. Lugares moles. Dissertação (Mestrado em Poéticas Visuais)

- Escola de Comunicações e Artes, Universidade de São Paulo, 2007.

- Exercícios de leitoria. Tese (Doutorado em Poéticas Visuais) - Escola de Comunicações e Artes, Universidade de São Paulo, 2012.

BAUSBAUM, Ricardo. Você gostaria de participar de uma experiência artística $(+N B P)$. Tese (Doutorado em Poéticas Visuais) - Escola de Comunicações e Artes, Universidade de São Paulo, 2008.

BORG, Erik. The Experience of Writing a Practice-based Thesis in Fine Art and Design. Tese (Doutorado em Educação) - Escola de Educação, Universidade de Leeds, 2009.

BUENO, Cláudio. Campos de invisibilidade. Tese (Doutorado em Poéticas Visuais) Escola de Comunicações e Artes, Universidade de São Paulo, 2015. 
CAIXETA, Viviane Ferreira. A institucionalização do fomento à pesquisa em Artes no CNPq: O Programa Básico de Artes. Dissertação (Mestrado em Desenvolvimento Sustentável) - Universidade de Brasília, 2007.

CESAR, Vitor. Artista é público. Dissertação (Mestrado em Poéticas Visuais). Escola de Comunicações e Artes, Universidade de São Paulo, 2009.

DARDOT, Marilá. A de arte: a coleção Duda Miranda. Dissertação (Mestrado em Linguagens Visuais) - Escola de Belas Artes, Universidade Federal do Rio de Janeiro, 2003.

DWEK, Zizette Lagnado. Hélio Oiticica: o mapa do programa ambiental. Tese (Doutorado em Filosofia) - Faculdade de Filosofia, Letras e Ciências Humanas da Universidade de São Paulo, 2003.

GARBELOTTI, Raquel. In(audíveis): audiência e reflexividade para uma estéticapolítica. Tese (Doutorado em Poéticas Visuais) - Escola de Comunicações e Artes, Universidade de São Paulo, 2011.

GODÓI, Vagner. Máquinas que se exibem + máquinas funcionando. Dissertação (Mestrado em Estética e História da Arte) - Programa de Pós-Graduação Interunidades em Estética e História da Arte, Universidade de São Paulo, 2008.

GONÇALVES, Mônica Hoff. A virada educacional nas práticas artísticas e curatoriais contemporâneas e o contexto de arte brasileiro. Dissertação (Mestrado em Artes Visuais) - Instituto de Artes, Universidade Federal do Rio Grande do Sul, 2014.

HONORATO, Cayo. A formação do artista: conjunções e disjunções entre arte e Educação. Tese (Doutorado em Educação) - Faculdade de Educação, Universidade de São Paulo, 2011.

KUNSCH, Graziela. Projeto Mutirão. Dissertação (Mestrado em Poéticas Visuais) Escola de Comunicações e Artes, Universidade de São Paulo, 2008.

. Não caber + Início da pesquisa Estou na frente da câmera mas a minha cabeça está atrás dela ou A performance da diretora ou A performance da crítica. Tese (Doutorado em Meios e Processos Audiovisuais) - Escola de Comunicações e Artes, Universidade de São Paulo, 2016.

LUCAS, Renata. Visto de dentro, visto de fora. Tese (Doutorado em Poéticas Visuais) Escola de Comunicações e Artes, Universidade de São Paulo, 2008.

MARQUEZ, Renata Moreira. Geografias portáteis: arte e conhecimento espacial. Tese (Doutorado em Geografia) - Instituto de Geociências da Universidade de Minas Gerais, Belo Horizonte, 2009. 
MESQUITA, André Luiz. Insurgências poéticas: arte ativista e ação coletiva (19902000). Dissertação (Mestrado em História Social) - Faculdade de Filosofia, Letras e Ciências Humanas da Universidade de São Paulo, 2008.

. Mapas dissidentes: proposições sobre um mundo em crise (1960-2010). Tese (Doutorado em História Social) - Faculdade de Filosofia, Letras e Ciências Humanas da Universidade de São Paulo, 2013.

MORAES, Diogo de. Públicos em emergência: modos de usar ofertas institucionais e práticas artísticas. Dissertação (Mestrado em Poéticas Visuais) - Escola de Comunicações e Artes, Universidade de São Paulo, 2017.

MYRRHA, Lais. Sobre as possibilidades da impermanência: fotografia e monumento. Dissertação (Mestrado em Artes) - Escola de Belas Artes, Universidade Federal de Minas Gerais, 2007.

NELUND, Sidsel. Acts of Research: Knowledge Production in Contemporary Art between Knowledge Economy and Critical Practice. Tese (Doutorado em Artes e Estudos Culturais) - Instituto de Artes e Estudos Culturais, Universidade de Copenhague, 2014.

PAIM, Cláudia. Espaços de arte, espaços da arte: perguntas e respostas de iniciativas coletivas de artistas em Porto Alegre, anos 90. Dissertação (Mestrado em Artes Visuais) - Instituto de Artes da Universidade Federal do Rio Grande do Sul, 2004.

- Coletivos e iniciativas coletivas. Modos de fazer na América Latina contemporânea. Tese (Doutorado em Artes Visuais) - Instituto de Artes da Universidade Federal do Rio Grande do Sul, 2009.

PELED, Yiftah. DTEEP: dinâmicas e trocas entre estados de performance. Tese (Doutorado em Poéticas Visuais) - Escola de Comunicações e Artes, Universidade de São Paulo, 2013.

PRANDO, Felipe Cardoso de Mello. Campo neutral: limites e tensões entre práticas artísticas, curatoriais e instituições de arte. Tese (Doutorado em Poéticas Visuais) Escola de Comunicações e Artes, Universidade de São Paulo, 2016.

RAMIRO, Mario. O gabinê fluidificado e a fotografia dos espíritos no Brasil. Tese (Doutorado em Poéticas Visuais) - Escola de Comunicações e Artes, Universidade de São Paulo, 2008.

REDIN, Mayana. Das cosmologias: intervalo e infinito nas ficções do artista. Dissertação (Mestrado em Linguagens Visuais) - Escola de Belas Artes, Universidade Federal do Rio de Janeiro, 2013. 
RIBAS, Cristina Thorstenberg. Arquivo/desarquivo: condições, movimento, monotipia. Dissertação (Mestrado em Artes) - Instituto de Artes da Universidade do Estado do Rio de Janeiro, 2008.

RUPP, Bettina. Residências em arte contemporânea: espaço, tempo e interlocução. Tese (Doutorado em Artes Visuais) - Instituto de Artes da Universidade Federal do Rio Grande do Sul, 2017.

SCHULTZ, Vanessa. Lugar publicação: artistas e revistas. Dissertação (Mestrado em Artes Visuais) - Centro de Artes da Universidade do Estado de Santa Catarina, 2008.

SEVERO, André. Deriva de sentidos. Dissertação (Mestrado em Artes Visuais) Instituto de Artes, Universidade Federal do Rio Grande do Sul, 2007.

SILVEIRA, Regina. Anamorfas. Texto descritivo e apresentação. Dissertação (Mestrado em Poéticas Visuais) - Escola de Comunicações e Artes, Universidade de São Paulo, 1980.

- Simulacros. Tese (Doutorado em Poéticas Visuais) - Escola de Comunicações e Artes, Universidade de São Paulo, 1984.

SPRICIGO, Vinicius Pontes. Relato de outra modernidade: contribuições para uma reflexão crítica sobre a mediação da arte no contexto da globalização cultural. Tese (Doutorado em Poéticas Visuais) - Escola de Comunicações e Artes da Universidade de São Paulo, 2010.

STOLF, Raquel. Entre a palavra pênsil e a escuta porosa: [investigações sob proposições sonoras]. Tese (Doutorado em Artes Visuais) - Instituto de Artes, Universidade Federal do Rio Grande do Sul, 2011.

TAVARES, Ana Maria. Armadilhas para os sentidos: uma experiência no espaçotempo da arte. Tese (Doutorado em Poéticas Visuais) - Escola de Comunicações e Artes, Universidade de São Paulo, 2000.

TRAPLEV (Roberto Moreira Junior). Recibo 5/7. Práticas artísticas contemporâneas: articulação entre as diferentes esferas do circuito. Dissertação (Mestrado em Artes Visuais) - Centro de Artes da Universidade do Estado de Santa Catarina, 2007.

VISCONTI, Jacopo Crivelli. Novas derivas. Tese (Doutorado em Arquitetura em Urbanismo) - Faculdade de Arquitetura em Urbanismo da Universidade de São Paulo, 2012.

ZACCAGNINI, Carla. Dissertação: a obra como lugar do texto, o texto em lugar da obra. Dissertação (Mestrado em Poéticas Visuais) - Escola de Comunicações e Artes, Universidade de São Paulo, 2004. 
ZÓZIMO, Michel. Fluxorama: a edição de materiais de divulgação científica em outros fluxos. Tese (Doutorado em Artes Visuais) - Instituto de Artes, Universidade Federal do Rio Grande do Sul, 2014.

\section{Livros e Catálogos de Exposição}

AGUILAR, Gonzalo; CÁMARA, Mario. A máquina performática: a literatura no campo experimental. Rio de Janeiro: Rocco, 2017.

BISHOP, Claire. Artificial Hells: Participatory Art and the Politics of Spectatorship. Londres: Verso, 2012.

BASBAUM, Ricardo; REIS, Paulo; REZENDE, Ricardo. Panorama da Arte Brasileira 2001. Catálogo de exposição. São Paulo: Museu de Arte Moderna de São Paulo, 2001.

BASBAUM, Ricardo; HOLDER, Will; PETHICK, Emily. Diagrams, 1994 - ongoing. Catálogo de exposição. Berlim: Errant Bodies Press, 2016.

BAUDELAIRE, Charles. Sobre a modernidade/ O pintor da vida moderna. Rio de Janeiro: Paz e Terra, 1996.

BOURDIEU, Pierre. As regras da arte: gênese e estrutura do campo literário. São Paulo: Martins Fontes, 1992.

BOURRIAUD, Nicolas. Estética relacional. São Paulo: Martins Fontes, 2009.

. Pós-produção: como a arte reprograma o mundo contemporâneo. São Paulo: Martins Fontes, 2009.

BRITO, Ronaldo. $O$ moderno e o contemporâneo (o novo e o outro novo). Arte Brasileira Contemporânea - Caderno de Textos 1. Rio de Janeiro: Funarte, 1980.

CALDAS, Waltercio; BRITO, Ronaldo. Aparelhos. Rio de Janeiro: GBM Editora, 1979.

CAMPOS. Haroldo de. A arte no horizonte do provável: e outros ensaios. São Paulo: Perspectiva, 2010.

CANCLINI, Néstor García. A sociedade sem relato: Antropologia e Estética da Iminência. São Paulo: Edusp, 2012.

CAUQUELIN, Anne. Arte contemporânea: uma introdução. São Paulo: Martins, 2005. . Teorias da arte. São Paulo: Martins Fontes, 2005.

CLARK, Lygia. Livro-obra. Rio de Janeiro: s/ed., 1983.

CORRIGAN, Timothy. O filme-ensaio: desde Montaigne e depois de Marker. Campinas: Papirus, 2015. 
DANTO, Arthur C. O descredenciamento filosófico da arte. Belo Horizonte: Autêntica, 2014.

DELEUZE, Gilles. Foucault. São Paulo: Brasiliense, 2005.

. Conversações. São Paulo: Editora 34, 2010.

DELEUZE, Gilles; GUATTARI, Félix. O que é a filosofia? São Paulo: Editora 34, 1997.

. Mil Platôs: capitalismo e esquizofrenia. v. 1. São Paulo: Editora 34, 1995.

. Mil Platôs: capitalismo e esquizofrenia. v. 5. São Paulo: Editora 34, 1997.

CAMP, Marc-Antoine; Šiška, Blanka. Research Funding in the Arts. A Survey for Switzerland 2010/11 (Report). Berna: Swiss Science and Technology Council, 2011, p. 32. Disponível em: <https://www.swir.ch/images/stories/pdf/en/kunstbericht e.pdf>. Acesso em: 20 fev. 2018.

CAMPOS, Haroldo. Metalinguagem e outras metas: ensaios de teoria e crítica literária. São Paulo: Perspectiva, 1992.

CAZEAUX, Clive. Art, Research, Philosophy. Nova York: Routledge, 2017. (e-book Kindle).

CESAR, Marisa Flórido. Nós, o outro, o distante - na arte contemporânea brasileira. Rio de Janeiro: Editora Circuito, 2014.

CUNHA, Luiz Antonio. A universidade reformada: o golpe de 1964 e a modernização do ensino superior. Rio de Janeiro: Francisco Alves, 1988.

FILLIOU, Robert. Teaching and Learning as Performing Arts. Nova York: Kasper König, 1970.

FOUCAULT, Michel. As palavras e as coisas. São Paulo: Martins Fontes, 2000. . A arqueologia do saber. Rio de Janeiro: Forense Universitária, 2008.

FOSTER, Hal. O retorno do real. São Paulo: Cosac Naify, 2014.

FREIRE, Cristina. Poéticas do processo: arte conceitual no museu. São Paulo: Iluminuras, 1999.

. Arte conceitual. Rio de Janeiro: Zahar, 2006.

GELL, Alfred. Arte e agência. São Paulo: Ubu, 2018.

GINZBURG, Carlo. A micro-história e outros ensaios. Lisboa/Rio de Janeiro: DIFEL/Bertrand Brasil, 1991.

GUATTARI, Félix. As três ecologias. Campinas: Papirus, 2012

GIBBONS, Michael et al. The New Production of Knowledge: The Dynamics of Science and Research into Contemporary Societies. Londres: Sage, 1994.

JAKOBSON, Roman. Lingüística e comunicação. São Paulo: Cultrix, 2005. 
KESTER, Grant. Conversation Pieces: Community + Communication in Modern Art. Berkeley: University of California Press, 2004.

KRAUSS, Rosalind. A Voyage on the North Sea: Art in the Age of the Post-Medium Condition. Nova York: Thames \& Hudson, 2000.

KWON, Miwon. One Place After Another: Site-specific Art and Locational Identity. Cambridge: MIT Press, 2002.

LADDAGA, Reinaldo. Estética da emergência: a formação de outra cultura das artes. São Paulo: Martins Fontes, 2012.

. Estética de laboratório: estratégias das artes do presente. São Paulo: Martins Fontes, 2013.

LATOUR, Bruno. Reagregando o social: uma introdução à Teoria do Ator-Rede. Salvador/Bauru: Edufba/Edusc, 2012.

LYOTARD, Jean-François; CHAPUT, Thierry. Les immatériaux, v. 2: Album et Inventaire. Catálogo de exposição. Paris: Éditions du Centre G. Pompidou, 1985.

LIPPARD, Lucy. Undermining: A Wild Ride Through Land Use, Politics, and Art in the Changing West. Nova York: The New Press, 2014.

MACHADO, Arlindo. Máquina e imaginário: o desafio das poéticas tecnológicas. São Paulo, Edusp, 1996.

McSHINE, Kynaston (ed.). Information. Catálogo de exposição. Nova York: The Museum of Modern Art, 1970.

MELIM, Regina. Performance nas artes visuais. Rio de Janeiro: Zahar, 2008.

MELTZER, Eve. Systems We Have Loved: Conceptual Art, Affect, and the Antihumanist Turn. Chicago: University of Chicago Press, 2013.

MILLET, Catherine. A arte contemporânea. Lisboa: Instituto Piaget, 2000.

MORIN, Edgar. Introdução ao pensamento complexo. Porto Alegre: Sulina, 2005.

MOTTA, Rodrigo Patto Sá. As universidades e o regime militar: cultura política brasileira e modernização autoritária. Rio de Janeiro: Zahar, 2014.

NUNES, Kamilla. Espaços autônomos de arte contemporânea. Rio de Janeiro: Circuito, 2013.

OECD. Frascati Manual 2015: Guidelines for Collecting and Reporting Data on Research and Experimental Development, The Measurement of Scientific, Technological and Innovation Activities. Paris: OECD Publishing, 2015. Disponível em: <https://doi.org/10.1787/9789264239012-en>. Acesso em: 30 jan 2018.

OITICICA, Hélio. Conglomerado Newyorkaises. Organização de César Oiticica Filho e Frederico Coelho. Rio de Janeiro: Beco do Azougue, 2013. 
ORTEGA, Francisco. Genealogia da amizade. São Paulo: Iluminuras, 2002.

OSBORNE, Peter. Conceptual Art. Londres: Phaidon, 2002.

. Anywhere or Not At All: Philosophy of Contemporary Art. Londres: Verso Books, 2013.

. The Postconceptual Condition: Critical Essays. Londres: Verso Books, 2018. (ebook Kindle).

PEVSNER, Nikolaus. Academias de arte: passado e presente. São Paulo: Companhia das Letras, 2005.

PLAZA, Julio. Poéticas visuais. Catálogo de exposição. São Paulo: MAC USP, 1977. . Tradução intersemiótica. São Paulo: Perspectiva, 2003.

PRICE, Seth. Dispersion. 2002. Disponível em: <http://www.distributedhistory.com/ Dispersion2016.pdf>. Acesso em: 25 jan. 2016.

RANCIÈRE, Jacques. O espectador emancipado. São Paulo: WMF Martins Fontes, 2012.

SVENUNGSSON, Jan. An Artist's Text Book. Helsinque: Finnish Academy of Fine Arts, 2007.

ZAMBONI, Silvio. A pesquisa em arte: um paralelo entre arte e ciência. Campinas, SP: Editora Autores Associados, 1998.

\section{Coletâneas de Textos (Livros, Revistas ou Websites)}

AMARAL, Aracy Abreu (org). Projeto construtivo brasileiro na arte (1950-1962). São Paulo: Pinacoteca do Estado, 2015.

Art \& Research, v. 2, $\mathrm{n}^{\mathrm{O}}$ 2, "A Gathering of Artistic Research: From New Science to Nameless Science", Glasgow School of Art, 2009.

ALBERRO, Alexander, STIMSON, Blake (eds.). Institutional Critique: an anthology of artists' writings. Cambridge: MIT Press, 2009.

AMBROZIC, Mara; VETTESE, Angela (ed.). Art as a Thinking Process: Visual Forms of Knowledge Production. Berlim, Nova York: Sternberg Press, 2013.

BALKEMA, Annette; SLAGER, Henk (eds.). Artistic Research. Lier en Boog (L\&B), Series of Philosophy of Art and Art Theory, v. 18. Amsterdã: Rodopi, 2004.

BARCELlOS, Vera Chaves (org.). Julio Plaza Poetica/Política. Porto Alegre: Fundação Vera Chaves Barcellos, 2013. 
BASBAUM, Ricardo (org.). Arte contemporânea brasileira: texturas, dicções, ficções, estratégias. Rio de Janeiro: ContraCapa, 2001. . Além da pureza visual. Porto Alegre: Zouk, 2007.

BORGDORFF, Henk. The Conflict of the Faculties: Perspectives on Artistic Research and Academia. Leiden: Leiden University Press, 2012.

BRITES, Blanca; TESSLER, Elida (orgs). O meio como ponto zero: metodologia da pesquisa em artes plásticas. Porto Alegre: Editora da UFRGS, 2002.

BUSCH, Kathrin; LESAGE, Dieter (eds.). A Portrait of the Artist as Researcher: the Academy and the Bologna Process. Antuérpia: MUHKA, 2007.

CADUFF, Corina et al. (ed.). Art and Artistic Research. Zurique: Scheidegger \& Spiess, 2009.

CAMPOS, Augusto de; PIGNATARI, Décio; CAMPOS, Haroldo de. Teoria da poesia concreta. Textos críticos e manifestos 1950-1960. Cotia, SP: Ateliê Editorial, 2006.

Ciência e Cultura, v, 66, nº4, "Núcleo Temático: Universidade na Ditadura”, São Paulo, out.-dez. 2014.

DOMBOIS, Florian et al. (eds). Intellectual Birdhouse: Artistic Practice as Research. Londres: Koenig, 2012.

DRONSFIELD, Jonathan Lahey (ed.). Materiality of Theory. Birmingham: Article Press, 2011.

e-flux journal, $\mathrm{n}^{0} 3$, fev. 2009. Disponível em: <https://www.e-flux.com/journal/o3>. Acesso em: 9 jan. 2016.

, no ${ }^{0}$, mar. 2009. Disponível em: <https://www.e-flux.com/journal/o4>. Acesso em: 14 jan. 2016.

ELKINS, James (ed.) Artists with PhDs: On the New Doctoral Degree in Studio Art. Washington DC: New Academia Publishing, 2014.

FERREIRA, Glória; COTRIM, Cecília (orgs.). Escritos de artistas: anos 60/70, Rio de Janeiro: Zahar, 2006.

HARRISON, Charles; WOOD, Paul (eds.). Art in Theory, 1900-2000: An Anthology of Changing Ideas. Oxford: Blackwell, 2004.

HOFFMAN, Jens (ed). The Next Documenta Should Be Curated By An Artist. e-flux Projects. 2004. Disponível em: <http://projects.e-flux.com/next_doc>. Acesso em: 23 jan. 2016.

KAILA, Jan; SLAGER, Henk. Doing Research. Writings from the Finnish Academy of Fine Arts $-\mathrm{n}^{0} 3$. Helsinque: The Finnish Academy of Fine Arts, 2012. 
KAPROW, Allan. Essays on the Blurring of Art and Life. Organização de Jeff Kelley. Los Angeles: University of California Press, 1993.

LIESE, Jennifer (ed.). Social Medium: Artists Writing, 2000-2015. Nova York: Paper Monument, 2016.

MACHADO, Arlindo Machado (org.). Made in Brasil: três décadas do vídeo brasileiro. São Paulo: Iluminuras/ Itaú Cultural, 2007.

MADOFF, Steven Henry (ed.). Art School: Propositions for the 21st Century. Massachusetts: MIT Press, 2009.

maHKUzine - Journal of Artistic Research, no 7, "Nameless Science", Escola de Artes de Utrecht (HKU), Summer 2009. , no 8, "Epistemic Encounters”, Escola de Artes de Utrecht (HKU), Winter 2010. , “As the Academy Turns”, Escola de Artes de Utrecht (HKU), Summer 2011.

MOREIRA, Maria Carla Guarinello de Araujo (org.). Arte em pesquisa. Londrina: EDUEL, 2005.

NELSON, Robin (ed.) Practice as Research in the Arts: Principles, Protocols, Pedagogies, Resistances. Basingstoke: Palgrave Macmillan, 2013.

O’NEILL, Paul; WILSON, Mick (eds.). Curating and the Educational Turn. Londres: Open Editions, 2010. . Curating Research. Londres: Open Editions, 2015.

PILLAR, Analice et al. (org.). Pesquisa em artes plásticas. Porto Alegre: UFRGS/ANPAP, 1993.

PRADO, Gilbertto; TAVARES, Monica; Tavares; ARANTES, Priscila (orgs.) Diálogos transdisciplinares: arte e pesquisa. São Paulo: ECA/USP, 2016.

QUARESMA, José; DIAS, Fernando Rosa. Investigação em artes: a oscilação dos métodos. Lisboa: Centro de Filosofia - Faculdade de Letras da Universidade de Lisboa, 2015.

Revista ítem, $\mathrm{n}^{0}$ 1. Textos de Artistas. Rio de Janeiro, jun. 1995.

SLAGER, Henk (ed.). Temporary Autonomous Research. Catálogo do Pavilhão de Amsterdã na 9a Bienal de Xangai. Utrecht: Metropolis M Books, 2012. . (ed.) Experimental Aesthetics - Taipei Biennal. Utrecht: Metropolis M Books, 2014.

. The Pleasure of Research. Berlim: Hatje Cantz, 2015.

SMITHSON, Robert. The Collected Writings. Berkeley: University of California Press, 1996. 
STILES, Kristine; SELZ, Peter (eds.). Theories and Documents of Contemporary Art: a Source Book of Artist's Writings. Los Angeles: University of California Press, 1996. SCHWAB, Michael; BORGDORFF, Henk (eds.). The Exposition of Artistic Research: Publishing Art in Academia. Amsterdã: Leiden University Press, 2014.

Texte zur Kunst, no 82, “Artistic Research”, Berlim, jun. 2011.

VIDOKLE, Anton. Exhibition as School in a Divided City. In: VIDOKLE, Anton; WALDVOGEL, Florian; EL-DAHAB, Mai Abu (ed.). Notes for an Art School Manifesta 6. 2006. Disponível em: <http://manifesta.org/wordpress/wp-content/ uploads/2010/o7/NotesForAnArtSchool.pdf>. Acesso em: 4 jan. 2016.

WESSELING, Janneke (ed.). See It Again, Say It Again: The Artist as Researcher (Antennae Series). Amsterdã: Valiz, 2011.

\section{Artigos e Capítulos}

ACTE... Un peu d'histoire. 2014. Disponível em: <http://www.institut-acte.cnrs.fr/ blog/bienvenue-sur-le-site-de-acte>. Acesso em: 12 mar. 2018.

AGAMBEN, Giorgio. O que é um dispositivo? In: O que é o contemporâneo? E outros ensaios. Chapecó: Argos, 2009, pp. 25-51.

ALBUQUERQUE, Fernanda Carvalho de. Lugares moles. MAPA - Memória Paço das Artes. Temporada de Projetos 2007. Disponível em: <http://mapa.pacodasartes .org.br/page.php?name=criticos\&op=detalhe\&ida=153\&idc=87>. Acesso em: 2 fev. 2017.

ALMEIDA, Catarina. The Problem of Artistic Research. Sisyphus - Journal of Education, v. 3, $\mathrm{n}^{\mathrm{o}}$ 1, Universidade de Lisboa, 2015, pp. 136-171. Disponível em: <http://revistas.rcaap.pt/sisyphus/article/view/7723>. Acesso em: 13 out. 2016, pp. 146-150.

ARLANDER, Annette. Artistic research in a Nordic context. In: Nelson Robin. (ed.) Practice as Research in the Arts. Principles, Protocols, Pedagogies, Resistances. Londres: Palgrave Macmillan, 2013, pp. 152-162.

ARCHEY, Karen. Performance and Pedagogy: All Talk, Some Action. MAP Magazine, $\mathrm{n}^{0}$ 20, Winter 2009. Disponível em: <http://mapmagazine.co.uk/8967/ performance-and-pedagogy-all>. Acesso em: 3 fev. 2016.

BALKEMA, Annette; SLAGER, Henk. Prologue. In: (ed.). Artistic Research. Lier en Boog (L\&B), Series of Philosophy of Art and Art Theory, v. 18. Amsterdã: Rodopi, 2004, pp. 9-10. 
BALKEMA, Annette et al. Discussion. In: BALKEMA, Annette; SLAGER, Henk (ed.). Artistic Research. Lier en Boog (L\&B), Series of Philosophy of Art and Art Theory, v. 18. Amsterdã: Rodopi, 2004, pp. 158-179.

BAKER, $\mathrm{Su}$ et al. CreativeArtsPhD: Future Proofing the Creative Arts in Higher Education (Report). Melbourne: University of Melbourne, 2009. Disponível em: <https://acuads.com.au/wp-content/uploads/2014/11/ALTC_Report_Final.pdf>. Acesso em: 15 fev. 2018.

BARBOSA, Ana Mae. Educação Artística. Estudos Avançados, v. 8, nº 22, pp. 491-494, São Paulo, 1994. Disponível em: <http://www.scielo.br/pdf/ea/v8n22/71.pdf>. Acesso em: 25 jan. 2018.

BADIOU, Alain. Arte e filosofia. In: . Pequeno manual de inestética. São Paulo: Estação Liberdade, 2002.

BALDON, Diana. Rehabilitating Counter-Production. In: BALDON, Diana; LAFER, Ilse. Counter-Production - Part 1. Catálogo de exposição. Viena: Generali Foundation, 2012, pp. 9-18.

BARRETO, Jorge Menna. Anotações sobre uma certa inclinação educativa de em uma trajetória (supostamente) artística. Urbânia, n. 5, São Paulo, 2014, pp. 214-223.

. Manual para um Café Educativo: guia para realização da obra. In: PRANDO, Felipe (ed.). Campo neutral. Catálogo de exposição. Curitiba: Museu da Gravura, 2014. Disponível em: <https://issuu.com/felipeprando/docs/campo_neutral_ miolo_10-12-2014_b>.Acesso em: 2 out. 2017.

. Deixe que o lugar determine. In: MARINHO, Claudia; CAETANO, Patrícia; RIBEIRO, Walmeri. Das artes e seus percursos sensíveis. São Paulo: Intermeios, 2016, pp. 201-206.

BARRETO, Jorge Menna; BATISTA, Helmut. Em revisão [diálogo em curso]. In: BATISTA, Helmut et al. (org.). Livro para responder. Rio de Janeiro: CAPACETE Entretenimentos, 2012.

BARRETO, Jorge Menna; GARBELOTTI, Raquel. Especificidade e (in)tradutibilidade. In: MANESCHY, Orlando; LIMA, Ana Paula Felicíssimo de Camargo. Já! Emergências contemporâneas. Belém: EDUFPA/ Mirante - Território Móvel, 2008, pp. 119-127.

BASBAUM, Ricardo. O que é NBP? Rio de Janeiro: Espaço Cultural Sérgio Porto, 1993. Folder. Disponível em: <http://www.nbp.pro.br/nbp.php>. Acesso em: 13 out. 2017. 
. (?)? Pergunta dentro de pergunta. Arte \& Ensaios, no 7, PPGAV/ EBA/ UFRJ, Rio de Janeiro, 2000.

. O papel do artista como agenciador de eventos e fomentador de produções frente à dinâmica do circuito da arte. In: $O$ visível e o invisível na arte atual. Belo Horizonte: CEIA - Centro de Experimentação e Informação de Arte, 2002, pp. 96119.

. Circuito de Arte em Deslocamento. Painel Investigações Contemporâneas. 2003. Disponível em: <http://site.videobrasil.org.br/pt/festival/arquivo/festival/progra ma/1402271>. Acesso em: 3 fev. 2017.

. E agora? Arte \& Ensaios, nº9, pp. 84-93, EBA/UFRJ, Rio de Janeiro, 2002. Disponível em: <https://www.ppgav.eba.ufrj.br/wp-content/uploads/2012/o1/Eagora-Ricardo-Basbaum.pdf>. Acesso em: 2 fev. 2017.

- Diferenças entre nós e eles. Entre lugares: arte e pensamento. Colóquio do Programa de Pós-Graduação em Ciência da Literatura da UFRJ, 2005. Disponível em: <http://www.ciencialit.letras.ufrj.br/entrelugares/diferencasentrenoseeles_f_ 2_.pdf>. Acesso em: 12 out. 2017.

. Relatório de uma visita ao MASC no dia 13 de junho de 2005. Disponível em: <http://www.nbp.pro.br/doc/relatorio_masc_1178.pdf>. Acesso em: 6 fev. 2017.

. Projeto NBP. Algumas pistas de um programa em processo. In: NAZARIO, Luiz; FRANCA, Patrícia. Concepções contemporâneas de arte. Belo Horizonte: Editora UFMG, 2006.

- Migração das palavras para a imagem. In: - Além da pureza visual. Porto Alegre: Zouk, 2007, pp. 27-47.

. Você gostaria de participar de uma experiência artística? Fórum Permanente, 2007. Disponível em: <http://www.forumpermanente.org/rede/nbp>. Acesso em: 17 fev. 2017.

. Deslocamentos rítmicos: o artista como agenciador, como curador e como crítico. In: LAGNADO, Lisette; PEDROSA, Adriano; VOLZ, Jochen (orgs.). $27^{a}$ Bienal de São Paulo: Seminários. Rio de Janeiro: Cobogó, 2008, pp. 57-74.

. Re-projetando (utrecht). ARS, v. 6, $\mathrm{n}^{0}{ }^{0} 11$, São Paulo, 2008. Disponível em: <http://www.scielo.br/pdf/ars/v6n11/o9.pdf>. Acesso em: 2 fev. 2017.

. Ricardo Basbaum (Relato). Uma gentil invenção. Catálogo de exposição. Rio de Janeiro: SESC, 2008.

. Você gostaria de participar de uma experiência artística. In: DE CARO, Marina (org.). Micropolis experimentais: traduções da arte para a educação (Projeto 
Pedagógico da $7^{\mathrm{a}}$ Bienal do Mercosul). Porto Alegre: Fundação Bienal do Mercosul, 2009.

. Would You Like to Participate in An Artistic Experience? Art \& Research, v. 2, $\mathrm{n}^{\circ} 2$, Glasgow School of Art, 2009. Disponível em: <http://www.artandresearch .org.uk/v2n2/pdfs/basbaum.pdf>. Acesso em: 2 fev. 2016.

. Em torno do "vírus de grupo". Lugar Comum, v. 1, nº 30 , UFRJ, Rio de Janeiro, 2010, pp. 135-146.

. collective-conversations. In: BALDON, Diana; LAFER, Ilse. Counter-Production

Part 3. Viena: Generali Foundation, 2012.

. Amo os artistas etc. In: Manual do artista-etc. Rio de Janeiro: Beco do Azougue, 2013, pp. 167-170.

. collective-conversations. In: BALDON, Diana; LAFER, Ilse (ed.). CounterProduction - Part 3. Catálogo de exposição. Viena: Generali Foundation, 2012, pp. $32-42$.

. O artista como pesquisador. In: . Manual do artista-etc. Rio de Janeiro: Beco do Azougue, 2013, pp. 193-201.

- Guia para participantes do projeto "Você gostaria de participar de uma experiência artística?”, 2014. Disponível em: <http://www.nbp.pro.br/doc/guia_ 2014_port_1407.pdf>.Acesso em: 2 fev. 2017.

. Mediações. In: FERNANDES, Mariana Queiroz (org.). Longitudes: a formação do artista contemporâneo no Brasil. São Paulo: Casa do Povo / Anamauê, 2014, pp. 24-33.

BASBAUM, Ricardo et al. Roteiro conversa coletiva: re-projetando (belo horizonte). In: BASBAUM, Ricardo; MARQUEZ, Renata (org.). conjs., re-bancos*: exercícios\&conversas. Catálogo de exposição. Belo Horizonte: Museu de Arte da Pampulha, 2012, pp. 30-51.

BENJAMIN, Walter. O autor como produtor. In: - Magia e Técnica, arte e política: ensaios sobre a literatura e história da cultura. Obras escolhidas, volume I. São Paulo: Brasiliense, 2017, posição 1769-2050 (e-book Kindle). . Sobre o conceito da história. In: - Magia e Técnica, arte e política: ensaios sobre a literatura e história da cultura. Obras escolhidas, volume I. São Paulo: Brasiliense, 2017, posição 3422-3572 (e-book Kindle).

BERARDI, Franco. Cognitarian Subjectivation. e-flux journal, $\mathrm{n}^{\mathrm{o}}$ 20, nov. 2010. Disponível em: <https://www.e-flux.com/journal/20/67633/cognitarian-subjecti vation>. Acesso em: 29 abr. 2016. 
BEUYS, Joseph. I Am Searching for Field Character. In: KUONI, Carin (org.). Energy Plan for the Western Man: Writings by and Interviews with the Artist: Joseph Beuys in America. Nova York: Four Walls Eight Windows, 1990, pp. 21-23. . A revolução somos nós. In: FERREIRA, Glória; COTRIM, Cecília (org). Escritos de Artistas. Anos 60/ 70. Rio de Janeiro: Zahar, 2009, pp. 300-324.

BEUYS, Joseph; BÖLL, Heinrich. Manifesto on the Foundation of a "Free International School for Creativity and Interdisciplinary Research”. In: TISDALL, Caroline. Art into Society, Society into Art: Seven German Artists. Londres: Institute of Contemporary Art, 1974, pp. 49-50.

BIGGS, Michael. Editorial: The Problem of Interpretation in Research in the Visual and Performing Arts. In: Working Papers in Art \& Design, $\mathrm{n}^{\mathrm{o}} 5$, University of Hertfordshire, 2008. Disponível em: <http://uhra.herts.ac.uk/bitstream/handle/2 299/7330/903920.pdf?sequence=1>. Acesso em: 17 out. 2017.

BISHOP, Claire. Antagonism and Relational Aesthetics. October, $\mathrm{n}^{\mathrm{o}}$ 110, pp. 51-79, Fall 2004.

BOLLE, Willi. Um painel com milhares de lâmpadas - metrópole e mega-cidade. In.: BENJAMIN, Walter. Passagens. Belo Horizonte/ São Paulo: Editora UFMG/ Imprensa Oficial, 2007, pp. 1.141-1.167.

BORGDORFF, Henk. The Conflict of the Faculties. On Theory, Practice and Research in Professional Arts Academies. In: __ . The Conflict of the Faculties: Perspectives on Artistic Research and Academia. Leiden: Leiden University Press, 2012, pp. 1426.

. The Debate on Research in the Arts. In: . The Conflict of the Faculties: Perspectives on Artistic Research and Academia. Leiden: Leiden University Press, 2012, pp. 28-55.

. Artistic Research and Academia: An Uneasy Relationship. In: . The Conflict of the Faculties: Perspectives on Artistic Research and Academia. Leiden: Leiden University Press, 2012, pp. 56-73

. Where Are We Today? The State of the Art in Artistic Research. In: . The Conflict of the Faculties: Perspectives on Artistic Research and Academia. Leiden: Leiden University Press, 2012, pp. 104-126.

. The Production of Knowledge in Artistic Research. In: The Conflict of the Faculties: Perspectives on Artistic Research and Academia. Leiden: Leiden University Press, 2012, pp. 140-173. 
- Artistic Practices and Epistemic Things. In: - The Conflict of the Faculties:

Perspectives on Artistic Research and Academia. Leiden: Leiden University Press, 2012, pp. 184-198.

BRETT, Guy. Ricardo Basbaum. Arte no plural. In: Brasil experimental: arte/vida, proposições e paradoxos. Rio de Janeiro: Contra Capa Livraria, 2009.

BRITO, Ronaldo. Análise do circuito. Malasartes, $\mathrm{n}^{0}$ 1, pp.5-6, Rio de Janeiro, set.-out. 1975.

BUCHLOH, Benjamin H. D. Conceptual Art 1962-1969: From the Aesthetic of Administration to the Critique of Institutions. October, $\mathrm{n}^{0} 55$, pp. 105-143, Winter 1990.

BULHÕES, Maria Amélia. A pós-graduação e a pesquisa em artes plásticas no Brasil. In: PILLAR, Analice et al. (org.). Pesquisa em artes plásticas. Porto Alegre: UFRGS/ANPAP, 1993, pp. 93-100.

BURGIN, Victor. Reflexões sobre "pesquisas" de doutorado em artes visuais. Arte \& Ensaios, $\mathrm{n}^{\circ}{ }_{25}$, pp. 184-195, EBA/UFRJ, Rio de Janeiro, 2013. Disponível em: <http://www.ppgav.eba.ufrj.br/wp-content/uploads/2013/12/ae25_victor.pdf>. Acesso em: 22 maio 2017, pp. 184-195.

BURNHAM, Jack. System Esthetics. Artforum, nº 7, pp. 30-35, set. 1968.

BUSCH, Kathrin. Artistic Research and the Poetics of Knowledge. Art \& Research, v. 2, $\mathrm{n}^{\mathrm{O}} 2$, Glasgow School of Art, 2009. Disponível em: <http://www.artandresearch .org.uk/v2n2/busch.html>. Acesso em: 2 fev. 2016.

BUTI, Marco. A arte na universidade, a universidade na arte. $A R S$, v. $7, \mathrm{n}^{0} 14, \mathrm{pp} .112-$ 129, São Paulo, 2009. Disponível em: <http://www.scielo.br/pdf/ars/v7n14/ v7n14a09.pdf> . Acesso em: 23 maio 2017.

CAMPOS, Haroldo de. Depoimento sobre arte e tecnologia: o espaço intersemiótico. In: DOMINGUES, Diana (org). A Arte no século XXI: a humanização das tecnologias. São Paulo: Editora Unesp, 1997, pp. 207-205.

COSTA, Luiz Cláudio da. O efeito-arquivo: a transversalidade como espaço discursivo. In: Anais do $18^{\circ}$ Encontro Nacional da ANPAP, Transversalidades nas Artes Visuais. Salvador: ANPAP, EDUFBA, 2009, pp. 2.157-2.171.

COTRIM, Cecilia. Arte e deriva: a escrita como processo-invenção. Arte \& Ensaio, ano 15, $\mathrm{n}^{0} 17$, PPGAV/ EBA/ UFRJ, Rio de Janeiro, 2008, pp. 64-73.

DARRAS, Bernard. Pesquisa em arte por ocasião dos doutorados baseados na prática. Um estudo do caso da Universidade de Paris 1 Sorbonne. $A R S$, v. 10, $\mathrm{n}^{0} 20, \mathrm{pp}$. 
108-127, São Paulo, nov. 2012. Disponível em: <http://www.revistas.usp.br/ars/ article/view/64427>. Acesso em: 23 mai. 2017.

DELEUZE, Gilles. O que é um dispositivo? Escola Nômade. 2016. Disponível em: $<$ http://escolanomade.org/2016/02/24/deleuze-o-que-e-um-dispositivo>. Acesso em: 30 mai. 2017.

DROMSFIELD, Jonathan Lahey. Theory as Art Practice: Notes for Discipline. Art \& Research, v. 2, $\mathrm{n}^{0}{ }_{2}$, Glasgow School of Art, 2009. Disponível em: <http://www .artandresearch.org.uk/v2n2/dronsfield.html>. Acesso em: 13 jan. 2016.

. Writing as Practice: Notes on Materiality of Theory for Practice-Based PhDs. In: ELKINS, James (ed.) Artists with PhDs: On the New Doctoral Degree in Studio Art. 2. ed. Washington DC: New Academia Publishing, 2014, pp. 325-338.

ELKINS, James. On Beyond Research and New Knowledge. In: . Artists with PhDs:

On the New Doctoral Degree in Studio Art. 1. ed. Washington DC: New Academia Publishing, 2009, pp. 111-133.

. Seven Questions on Arts as Research. An e-mail Interview with James Elkins. Texte Zur Kunst, $\mathrm{n}^{\circ}$ 82, Artistic Research, pp. 86-89, Berlim, jun. 2011.

. Introduction. In: (ed.) Artists with PhDs: On the New Doctoral Degree in Studio Art. 2. ed. Washington DC: New Academia Publishing, 2014, pp. xi-xxi. . Six Cultures of the PhD Around the World. In: . Artists with PhDs: On the New Doctoral Degree in Studio Art. 2. ed. Washington DC: New Academia Publishing, 2014, pp. 3-16.

. List of PhD Programs Around the World. In: Artists with PhDs: On the New Doctoral Degree in Studio Art. 2. ed. Washington DC: New Academia Publishing, 2014, pp. 17-32.

. Positive Ideas for PhD Programs. In: Artists with PhDs: On the New Doctoral Degree in Studio Art. 2. ed. Washington DC: New Academia Publishing, 2014, pp. 303-324.

ENWEZOR, Okwui. The Artist as Producer in Times of Crisis. In: MCQUIRE, Scott; PAPASTERGIADIS, Nikos Empires (ed.). Ruins + Networks: The Transcultural Agenda in Art. Melbourne: Melbourne University Press, 2005, pp. 11-51.

FABRIS, Annateresa. A pesquisa em artes visuais. Porto Arte, $\mathrm{n}^{\circ} 4$, pp. 12-19, UFRGS, Porto Alegre, 1991.

FÁVERO, Maria de Lourdes de Albuquerque. A universidade no Brasil: das origens à Reforma Universitária de 1968. Educar em Revista, nº28, pp. 17-36, dez. 2006. 
Disponível em: < http://www.scielo.br/pdf/er/n28/a03n28.pdf>. Acesso em: 19 fev. 2018.

FERVENZA, Hélio. Formas da apresentação: experiência, autonomia, escritos de artistas. In: COCCHIARALE, Fernando; SEVERO, André; PANITZ, Marília. Artes Visuais. Rio de Janeiro: Funarte, 2017, pp. 101-111. (Ensaios Brasileiros Contemporâneos).

FORTIN, Sylvie; GOSSELIN, Pierre. Considerações metodológicas para a pesquisa em arte no meio acadêmico. ARJ - Art Research Journal, v. 1, $\mathrm{n}^{\mathrm{0}} 1$, pp. 1-17, UFRN, maio 2014. Disponível em: <https://periodicos.ufrn.br/artresearchjournal/article/ view/5256>. Acesso em: 19 fev. 2018.

FOSTER, Hal. An Archival Impulse. October, v. 110, pp. 3-22, Cambridge, Fall 2004.

FRANK, Rike. When Form Starts Talking: On Lecture-Performances. Afterall Journal, n. 33, 2013. Disponível em: <https://www.afterall.org/journal/issue.33/whenform-starts-talking-on-lecture-performances.1>. Acesso em: 3 fev. 2016.

FRASER, Andrea. What's Intangible, Transitory, Mediating, Participatory, and Rendered in the Public Sphere? October, v. 80, pp. 111-116, Massachusetts, Spring 1997.

. Como prover um serviço artístico. Revista Carbono, n⿳0 4, Rio de Janeiro, 2013. Disponível em: <http://www.revistacarbono.com/wp-content/uploads/2013/o9/ Como-prover-um-servi\%C3\%A70-art\%C3\%ADstico-uma-introdu\%C3\%A7\%C3\% A30-Andrea-Fraser.pdf>. Acesso em: 20 fev. 2017.

FRAYLING, Christopher. Research in Art and Design. Royal College of Art Research Papers, v. 1, $\mathrm{n}^{0}{ }^{1}$. Londres: Royal College of Art, 1993. Disponível em: <http:// researchonline.rca.ac.uk/384/3/frayling_research_in_art_and_design_1993.pdf> . Acesso em: 27 dez. 2017.

FRIELING, Rudolf. The Archive, the Media, the Map and the Text. Media Art Net, 2004. Disponível em: <http://www.medienkunstnetz.de/themes/mapping_and _text/archive_map>.Acesso em: 26 jan. 2016.

GODFREY, Mark. The Artist as Historian. October, v. 120, pp. 140-172, Cambridge, Spring 2007.

GRAY, Carole. Inquiry Through Practice: Developing Appropriate Research Strategies, 1996. Disponível em: <http://carolegray.net/Papers\%20PDFs/ngnm .pdf>. Acesso em: 12 mar. 2018. 
GROYS, Boris. On Art Activism. e-flux journal, $\mathrm{n}^{0} 56$, jun. 2014. Disponível em: <https://www.e-flux.com/journal/56/60343/on-art-activism>. Acesso em: 22 jan. 2016.

GREFF, Jean-Pierre et al. Les défis de la recherche en art et en design en Suisse. Un cas d'école: la HEAD - Genève. Hermès, v. 72, $\mathrm{n}^{\mathrm{0}} 2$, pp. 75-84, Paris, 2015. Disponível em: <https://www.cairn.info/revue-hermes-la-revue-2015-2-page-75.htm>. Acesso em: 24 fev. 2018.

HOLERT, Tom. Art in the Knowledge-based Polis. e-flux journal, $\mathrm{n}^{\mathrm{0}} 3$, fev. 2009. Disponível em: <https://www.e-flux.com/journal/o3/68537/art-in-the-knowledge -based-polis>. Acesso em: 9 jan. 2016.

. Artistic Research: Anatomy of an Ascent. Texte Zur Kunst, no 82, pp. 38-63, jun. 2011.

HOLMES, Brian. Investigações extradisciplinares. Para uma nova crítica das instituições. Concinnitas, v. 1, $\mathrm{n}^{\mathrm{0}}$ 12, ano 9, pp. 6-13, jul. 2008. Disponível em: <http://www.e-publicacoes.uerj.br/index.php/concinnitas/article/view/2281 o/16272>. Acesso em: 25 jan. 2018.

- A personalidade potencial. Trans-Subjetividade na Sociedade de Controle. Cadernos de Subjetividade, ano 8, $\mathrm{n}^{\mathrm{0}}{ }_{13}$, Núcleo de Estudos e Pesquisas da Subjetividade, PUC-SP, São Paulo, 2011.

JAREMTCHUK, Dária. MAC do Zanini: o museu crítico do museu. In: OLIVEIRA, Emerson Dionísio Gomes de; COUTO, Maria de Fátima Morethy (orgs.). Instituições da arte. Porto Alegre: Zouk, 2012, pp. 69-86.

JONES, Timothy Emlyn. The PhD in Studio Art Revisited. In: ELKINS, James (ed.). Artists with PhDs: On the New Doctoral Degree in Studio Art. Washington DC: New Academia Publishing, 2014, pp. 97-127.

. The Studio Art Doctorate in America. In: ELKINS, James (ed.). Artists with PhDs: On the New Doctoral Degree in Studio Art. Washington DC: New Academia Publishing, 2014, pp. 169-177.

KÄLVEMARK, Torsten. University Politics and Practice-based Research. In: BIGGS, Michael; KARLSSON, Henrik (ed.). The Routledge Companion to Research in the Arts. Abingdon: Routledge, 2010, pp. 3-23.

KAPROW, Allan. A educação do an-artista II. Concinnitas, ano 5, no 6, p. 167-181, 2004.

KRAUSS, Rosalind. A escultura no campo ampliado. Arte \& Ensaios, no 17, pp. 128-137, EBA/ UFRJ, Rio de Janeiro, 2008. Disponível em: <https://www.ppgav.eba.ufrj.br 
/wp-content/uploads/2012/01/ae17_Rosalind_Krauss.pdf>. Acesso em: 26 jan. 2016.

KUNSCH, Graziela. R. x eu. (Relato). Evento Triplo com Ricardo Basbaum no Paço das Artes. Fórum Permanente, 2007. Disponível em: <www.forumpermanente.org/ revista/event_pres/mesas/basbaum/r-x-eu>. Acesso em: 4 maio 2016.

KUNSCH, Margarida Maria Krohling. Escola de Comunicações e Artes - ECA. In: GOLDEMBERG, José (org.). USP 80 anos. São Paulo: Edusp, 2015, pp. 25-38.

KWON, Miwon. Um lugar após o outro: anotações sobre site-specificity. Arte \& Ensaios, n. 17, pp. 166-187, EBA/UFRJ, Rio de Janeiro, 2008. Disponível em: $<$ https://www.ppgav.eba.ufrj.br/wp-content/uploads/2012/o1/ae17_Miwon_ Kwon.pdf $>$. Acesso em: 25 jan. 2016.

LAFER, Ilse. Counter-Production. In: BALDON, Diana; LAFER, Ilse (ed.). CounterProduction - Part 3. Catálogo de exposição. Viena: Generali Foundation, 2012, pp. 43-57.

LAFUENTE, Pablo. Ricardo Basbaum, Or That Elusive Object of Emancipation. Afterall, $\mathrm{n}^{0}$ 28, pp. 78-89, Autumn/Winter, 2011.

LATOUR, Bruno. From the World of Science to the World of Research? Science, v. 280, $\mathrm{n}^{\mathrm{o}}$ 5.361, pp. 208-209, 10 abr. 1998. Disponível em: <http://science.sciencemag .org/content/280/5361/208>. Acesso em: 23 jan. 2018.

. Como terminar uma tese de sociologia: pequeno diálogo entre um aluno e seu professor (um tanto socrático). Cadernos de Campo, $\mathrm{n}^{0} 14 / 15$, pp. 341-352, dez. 2006. Disponível em: <https://www.revistas.usp.br/cadernosdecampo/article/ view/50121/54239>. Acesso em: 1 maio 2018.

LEÃO, Lucia. Memória e método: complexidades da pesquisa acadêmica em processos de criação. In: VENTURELLI, Suzete; ROCHA, Cleomar (orgs.). Anais do \#15.ART. Mutações, confluências e experimentações na Arte e Tecnologia. Brasília: UNB, 2016, pp. 118-127.

LESAGE, Dieter. The Academy is Back: On Education, the Bologna Process, and the Doctorate in the Arts. e-flux journal, $\mathrm{n}^{\circ} 4$, mar. 2009. Disponível em: $<$ https://www.e-flux.com/journal/o4/68577/the-academy-is-back-on-educationthe-bologna-process-and-the-doctorate-in-the-arts >. Acesso em: 22 jan. 2016. . Who's Afraid of Artistic Research? On Measuring Artistic Research Output. Art \& Research, v. 2, $\mathrm{n}^{0}$, Glasgow School of Art, 2009. Disponível em: <http://www.art andresearch.org.uk/v2n2/lesage.html>. Acesso em: 2 fev. 2016. 
LINGNER, Michael. Reflections on/as Artists' Theories, 2006. Disponível em: <http:// archiv.ask23.de/draft/archiv/ml_publikationen/kto6-3ae.html>. Acesso em: 26 jun. 2016.

LILJA, Efva. The Development of Artistic Research in Sweden 200o-2012, 2013. Disponível em: <http://www.efvalilja.se/pdf/Artistic-research-in-Sweden-20oo2012.pdf>. Acesso em: 20 fev. 2017.

MACHADO, Arlindo. A pesquisa em arte em três atos. PRADO, Gilbertto; TAVARES, Monica; Tavares; ARANTES, Priscila (orgs.). Diálogos transdisciplinares: arte e pesquisa. São Paulo: ECA-USP, 2016, pp. 44-52.

MAHARAJ, Sarat. Unfinishable Sketch of 'An Unknown Object In 4D': Scenes of Artistic Research. In: BALKEMA, Annette; SLAGER, Henk (eds.). Artistic Research. Amsterdã: Rodopi, 2004, pp. 39-58.

. Know-how and No-how: Stopgap Notes on "Method" in Visual Art as Knowledge Production. Art \& Research, v. 2, $\mathrm{n}^{\mathrm{0}} 2$, Glasgow School of Art, 2009. Disponível em: <http://www.artandresearch.org.uk/v2n2/maharaj.html>. Acesso em: 2 fev. 2016.

MACIEL, Katia. Ricardo Basbaum: a geometria do conceito e a participação comunicacional. In: Luiz Cláudio da Costa (org.). Dispositivos de registro na arte contemporânea. Rio de Janeiro: Contracapa, 2009.

MARQUEZ, Renata. Masterplan NBP. In: BASBAUM, Ricardo; MARQUEZ, Renata (orgs.). conjs., re-bancos*: exercícios\&conversas. Catálogo de exposição. Belo Horizonte: Museu de Arte da Pampulha, 2012, pp. 6-17.

MEDEIROS, Maria Beatriz. 2001-2004, uma longa e divertida jornada de doação, isto é, de "experiência de liberdade”. In: OLIVEIRA, Sandra e MAKOWIECKY, Sandra (org.). Uma história da Associação Nacional de Pesquisadores em Artes Plásticas, 2008, pp. 80-84.

MEIRELES, Cildo. Quem se desloca recebe, quem pede tem preferência. Malasartes, $\mathrm{n}^{0} 1$, pp. 14-19, Rio de Janeiro, set.- out. 1975.

MELIM, Regina. Formas distendidas de performance. Arte em pesquisa: especificidades. Anais do $13^{\circ}$ Encontro Nacional da ANPAP. Brasília: ANPAP, UnB, 2004, pp. 422-426.

MILDER, Patricia. Teaching as Art: The Contemporary Lecture-Performance. PAJ: A Journal of Performance and Art, v. 33, $\mathrm{n}^{\mathrm{0}} 1$, pp. 13-27, 2010.

MONACHESI, Juliana e FERRAZ, Tatiana. Arte e universidade - novas estratégias de reflexão. Revista Número, $\mathrm{n}^{0} 3$, São Paulo, 2003. Disponível em: 
<http://www.forumpermanente.org/rede/numero/rev-numero3/tresjulianaetati ferraz>. Acesso em: 7 out. 2014.

NAVARRO, Santiago García. Formas de pensar. 2004. E-nformes do Canal Contemporâneo, 19 de fevereiro de 2004. Disponível em: <http://www.canal contemporaneo.art.br/e-nformes.php?codigo=510>. Acesso em: 16 jun. 2018.

NEVES, Galciane. Fragmento da palavra como lugar: escrituras, desleituras e leitorias de Jorge Menna Barreto. Arte \& Ensaios, no 16, pp. 36-41, EBA/UFRJ, Rio de Janeiro, 2008. Disponível em: <http://www.ppgav.eba.ufrj.br/wp-content/ uploads/2015/03/dossie-galciani.pdf >. Acesso em: 5 out. 2017.

NOYA PINTO, Virgílio. Escola de Comunicações e Artes. Estudos Avançados, v. 8, no 22, pp. 503-506, São Paulo, 1994. Disponível em: <http://www.scielo.br/pdf/ ea/v8n22/74.pdf >. Acesso em: 25 jan. 2018.

PLAZA, Julio. Arte, ciência, pesquisa: relações. Trilhas, nº6, pp. 21-32, Campinas, jul.dez. 1997.

. Arte/ciência: uma consciência. ARS, v. 1, $\mathrm{n}^{0} 1$, São Paulo, 2003, pp. 36-47. Disponível em: <http://www.scielo.br/pdf/ars/vın1/o4.pdf>. Acesso em: 27 set. 2017.

PASSERON, René. Da estética à poiética. Porto Arte, v. $8, \mathrm{n}^{0}{ }^{\mathrm{1}}$, pp. 103-116, Porto Alegre, 1997.

PECCININI, Daisy. Crônica dos primeiros tempos da ANPAP (1985 - 1991 2017). 25 set. 2017. Disponível em: <http://www.anpap.org.br/wp-content/uploads/2017/ 09/História-da-ANPAP-Crônica-dos-Primeiros-Tempos-DAISY.pdf>. Acesso em: 5 out. 2017.

PELED, Yiftah. Metodologias em poéticas visuais. Porto Arte, v. 19, nº 33, pp. 115-132, UFRGS, Porto Alegre, dez. 2013. Disponível em: <http://seer.ufrgs.br/PortoArte/ article/view/44073/27686>. Acesso em: 4 jul. 2016.

PISANO, Falke. A Sculpture Turning into a Conversation (Part one: description), 2006. Disponível em: <http://falkepisano.info/sculpture-turning-conversationtext>. Acesso em: 13 out. 2017.

PRADO, Gilbertto. Breve relato da Pós-Graduação em Artes Visuais da ECA-USP. ARS, v. 7, $\mathrm{n}^{0}{ }_{13}$, pp. 98-101, São Paulo, 2009. Disponível em: <www.scielo.br/pdf/ars/ v7n13/arsv7n13a6.pdf >. Acesso em: 13 jan. 2018.

PRADO, Gilbertto; SOGABE, Milton Sogabe; GUASQUE, Yara. Breve História Artistic Research in Brazil. JAR - Journal for Artistic Research, 2018. Disponível 
em: <jar-online.net/breve-historia-artistic-research-brazil>. Acesso em: 28 jun. 2018.

PRATES, Katia Maria Kariya. O texto imaginado: observações sobre escritos de Jorge Menna Barreto. Gama, Lisboa, $\mathrm{n}^{\mathrm{0}} 1$, Faculdade de Belas-Artes da Universidade de Lisboa, pp. 156-160, 2013.

RESENDE, José. Formação do artista no Brasil. ARS, v. 3, $\mathrm{n}^{\mathrm{0}} 5$, pp. 22-29, São Paulo, jan. 2005. Disponível em: <http://www.scielo.br/pdf/ars/v3n5/o2.pdf>. Acesso em: 23 maio 2017.

REY, Sandra. Da prática à teoria: três instâncias metodológicas sobre a pesquisa em artes visuais. Porto Arte, nº 13, v. 7, pp. 81-95, Porto Alegre, 1996.

. A dimensão crítica dos escritos de artistas na arte contemporânea. Pós:, v. 1, $\mathrm{n}^{\mathrm{0}}{ }_{1}$, pp. 8-15, UFMG, Belo Horizonte, maio 2008. Disponível em: < https://www.eba .ufmg.br/revistapos/index.php/pos/article/view/2/1>. Acesso em: 16 set. 2016.

ROELSTRAETE, Dieter. The Way of the Shovel: On the Archeological Imaginary in Art. e-flux journal, $\mathrm{n}^{\circ} 4$, mar. 2009. Disponível em: <https://www.e-flux.com/journal/ 04/68582/the-way-of-the-shovel-on-the-archeological-imaginary-in-art>. Acesso em: 14 jan. 2016.

. Critical Mess: On the Ruins of The Museum's Research Departments. Mousse Magazine, $\mathrm{n}^{\circ}$ 26, Milão, 2010. Disponível em: <http://moussemagazine.it/dieterroelstraete-art-schools-2010>. Acesso em: 17 jun. 2017.

ROGOFF, Irit. Practicing Research: Singularising Knowledge. MaHKUzine: Journal of Artistic Research, $\mathrm{n}^{\circ}$ 9, Summer, Utrecht, 2010, pp. 37-42.

. Turning. In: O’NEILL, Paul; WILSON, Mick (eds.). Curating and the Educational Turn. Londres: Open Editions, 2010, pp. 32-46.

ROSENTHAL, Dália. Joseph Beuys: o elemento material como agente social. ARS, v. 9, n. 18, pp. 110-133, São Paulo, 2011. Disponível em: <http://www.scielo.br/pdf/ars /v9n18/v9n18ao8.pdf>. Acesso em: 26 jan. 2016.

SANTAELLA, Lucia. Transcriar, transluzir, transluciferar: a teoria da tradução de Haroldo de Campos. In: MOTTA, Leda Tenório da. Céu acima: para um "tombeau" de Haroldo de Campos. São Paulo: Perspectiva, 2005, pp. 221-232.

SANTIAGO, Debora Maria. Aproximações entre arte, educação e agroecologia em projetos artísticos. Art\&Sensorium, v. 4, $\mathrm{n}^{0} 1$, pp. 27-39, jun. 2017. Disponível em: <http://periodicos.unespar.edu.br/index.php/sensorium/article/view/1704/1049 $>$. Acesso em: 8 set. 2017. 
SANTOS, Cássio Miranda dos. Tradições e contradições da pós-graduação no Brasil. Educação \& Sociedade, v. 24, n83, pp. 627-641, Unicamp, Campinas, ago. 2003. SCHWAB, Michael; BORGDORFF, Henk. Introduction. In: The Exposition of Artistic Research: Publishing Art in Academia. Leiden: Leiden University Press, 2014.

SHEIKH, Simon. Letter to Jane (Investigation of a Function). In: O’NEILL, Paul e Wilson, Mick (ed.). Curating and the Educational Turn. Londres: Open Editions, 2010, pp. 61-75.

SLAGER, Henk. Temporary Autonomous Research. In: The Pleasure of Research. Berlim: Hatje Cantz, 2015, pp. 7-14.

SOGABE, Milton. Arte e Pesquisa na Academia. In: RIBEIRO, Walmeri e ROCHA, Thereza (eds.). Das artes e seus territórios sensíveis. São Paulo: Intermeios, 2014, pp. 21-32.

. O ensino de artes e a formação do artista na academia. Marcelina, v. 4, pp. 29-38, FASM, São Paulo, 2010.

STEYERL, Hito. Estética da resistência? Pesquisa artística como disciplina e conflito. Concinnitas, ano 17, v. 1, n. 28, pp. 459-469, set. 2016. Disponível em: <http://www.e-publicacoes.uerj.br/index.php/concinnitas/article/view/25932/18 611>. Acesso em: 4 jun. 2017.

SUCUPIRA, Newton. Antecedentes e primórdios da pós-graduação. Forum Educacional, v. 4, $\mathrm{n}^{\mathrm{o}} 4$, pp. 3-18, out. 1980. Disponível em: <http://biblioteca digital.fgv.br/ojs/index.php/fe/article/view/60545/58792>. Acesso em: 14 fev. 2018.

TELLES, Martha; TORRES, Fernanda. A relação entre crítica e produção na formação de um pensamento contemporâneo de arte no Brasil na década de 1970. ARS, v. 15, n. 29, pp. 174-199, ECA-USP, São Paulo jun. 2017. Disponível em: <http://www .scielo.br/pdf/ars/v15n29/2178-0447-ars-15-29-0174.pdf>. Acesso em: 11 jul. 2018.

VIDOKLE, Anton. From Exhibition to School. Notes from unitednationsplaza. In: MADOFF, Steven Henry (ed.). Art School: Propositions for the 21st Century. Massachusetts: MIT Press, 2009, pp. 189-200.

WISNIOSKI, Matthew; TECH, Virginia. Why MIT Institutionalized the Avant-Garde: Negotiating Aesthetic Virtue in the Postwar Defense Institute. Configurations, v. 21, $\mathrm{n}^{\mathrm{0}} 1$, Winter 2013, pp. 85-116. 
ZAMBONI, Silvio. Situação atual da pesquisa em/sobre arte. In: MOREIRA, Maria Carla Guarinello de Araújo (org.). Arte em pesquisa. Londrina: EDUEL, 2005, pp. 189-204.

. Alguns fragmentos da história das Artes Plásticas no Brasil (1993-1995). In: RAMALHO E OLIVEIRA, Sandra Regina; MAKOWIECKY, Sandra (orgs.). Uma história da Associação Nacional de Pesquisadores em Artes Plásticas. Florianópolis: UDESC, 2008, pp. 54-63.

ZANINI, Walter. Elementos sobre a pesquisa em Artes Plásticas no Brasil e ANPAP (1987-1989). In: RAMALHO E OLIVEIRA, Sandra; MAKOWIECKY, Sandra (orgs.). Uma história da Associação Nacional de Pesquisadores em Artes Plásticas. Florianópolis: UDESC, 2008, pp. 33-38.

. Arte e história da arte. Estudos Avançados, v. 8, $\mathrm{n}^{\mathrm{0}} 22$, pp. 487-489, São Paulo, 1994. Disponível em: <http://www.scielo.br/pdf/ea/v8n22/70.pdf>. Acesso em: 17 jan. 2018.

ZILIO, Carlos. Formação do artista plástico no Brasil: o caso da Escola de Belas Artes. Arte \& Ensaios, v. 1, nº1, pp. 25-32, EBA/ UFRJ, Rio de Janeiro, 1994.

\section{Entrevistas e Conversas}

BARRETO, Jorge Menna; MIRAGAIA, Marília. Entrevista concedida à jornalista Marília Miragaia em agosto 2016. Disponível em: <http://cargocollective.com /jorgemennabarreto/32-Bienal-SP-Restauro>. Acesso em: 3 out. 2017.

BASBAUM, Ricardo; COTRIM, Cecília. Fluindo de diferença para diferença. Cultura e Pensamento, $\mathrm{n}^{\mathrm{O}}$ 2, 2007, pp. 70-77.

BASBAUM, Ricardo; LEÓN, Daniel Reyes. Entrevista a Ricardo Basbaum. Arte y Crítica. Relatos Críticos de Arte, 2007. Disponível em: <antiguo.arteycritica.org/ default_077.html>.Acesso em: $17 \mathrm{fev.} 2017$.

BASBAUM, Ricardo; VILELA, Soraia. Você gostaria de participar de uma experiência artística? Deutch Welle World, 2007. Disponível em: <https://p.dw.com/p/AL $\mathrm{NH}>$. Acesso em: 6 jan 2017.

BASBAUM, Ricardo; SCOVINO, Felipe. Ricardo Basbaum. In: SCOVINO, Felipe (org). Arquivo contemporâneo. Rio de Janeiro: 7Letras, 2009, pp. 71-93.

BASBAUM, Ricardo; PAOLA, Modesta di. Entrevista com Ricardo Basbaum. Interartive: A Platform for Contemporary Art and Thought, 2010. Disponível em: 
$<$ https://interartive.org/2010/o1/ricardo-basbaum-entrevista >. Acesso em: 23 fev. 2017.

BASBAUM, Ricardo; MARQUEZ, Renata et al., Conversa pública com Ricardo Basbaum. In: BASBAUM, Ricardo; MARQUEZ, Renata (orgs.). conjs., re-bancos*: exercícios\&conversas. Catálogo de exposição. Belo Horizonte: Museu de Arte da Pampulha, 2012, pp. 84-96.

BASBAUM, Ricardo. Só funciona nessa responsabilização do outro por uma ação não idealizada. Arte \& Ensaio, v. 25, pp. 7-33, UFRJ, Rio de Janeiro, 2013.

BASBAUM, Ricardo; FRAGA, Marina. Carbono entrevista Ricardo Basbaum. Revista Carbono, $\mathrm{n}^{0}$ 2, Rio de Janeiro, 2013. Disponível em: <http://revistacarbono.com/ artigos/o2carbono-entrevista-ricardo-basbaum>. Acesso em: 23 out. 2016.

BASBAUM, Ricardo; KIFFER, Ana; REZENDE, Renato. Ricardo Basbaum. In: KIFFER, Ana; REZENDE, Renato; BIDENT, Christophe (orgs.). Experiência e arte contemporânea. Rio de Janeiro: Circuito, 2013, pp. 68-84.

BASBAUM, Ricardo; ARCANJO, Edison do Carmo. Os Festivais de Verão em Nova Almeida e o Projeto "Você Gostaria de Participar de uma Experiência Artística?", Revista-Valise, Porto Alegre, v. 4, n ${ }^{\circ} 7$, pp. 29-38, Porto Alegre, 2014.

BASBAUM, Ricardo; FRAGA, Marina et al. Complexidade, metabiologia e criatividade. Conversa com Gregory Chaitin, Ricardo Basbaum e Virginia Chaitin. Revista Carbono, $\mathrm{n}^{\mathrm{0}}$ 7, Rio de Janeiro, 2014. Disponível em: <http://revistacarbono.com /artigos/o7complexidade-metabiologia>. Acesso em: 3 fev. 2017.

BASBAUM, Ricardo. Sobre o et cetera. Entrevista concedida a Duda Kuhnert. Revista Beira, $\quad 2^{\text {a }}$ edição - Trabalho, 9 out. 2016. Disponível em: $<$ https://medium.com/revista-beira/entrevista-com-ricardo-basbaum-85bbb4foce a9>. Acesso em: 15 out. 2016.

FRANKE, Anselm; CANELA, Juan. An "Undisciplined" Form of Knowledge. Mousse Magazine, 2017. Disponível em: <moussemagazine.it/undisciplined-form-know ledge-anselm-franke>. Acesso em: 18 jun. 2017.

LATOUR, Bruno; FRANKE, Anselm. Angels Without Wings. In: FRANKE, Anselm. Animism, v. I, Berlim: Sternberg Press, 2010.

NADOR, Mônica; BARRETO, Jorge Menna. As paredes pinturas de Mônica Nador. Conversa entre Mônica Nador e Jorge Menna Barreto sobre territórios e sentidos na arte. In: CANTON, Katia; PESSOA, Fernando (orgs.). Sentidos na/da arte contemporânea. Vila Velha/Rio de Janeiro: Associação Museu Ferroviário Vale do Rio Doce, 2007. 
OITICICA, Hélio; CARDOSO, Ivan. Depoimento concedido a Ivan Cardoso para o filme H.O. [jan. 1979]. In: FILHO, Cesar Oiticica e VIEIRA, Ingrid (orgs.). Hélio Oiticica. Rio de Janeiro: Beco do Azougue, 2009, pp. 226-243. (Encontros).

ZANINI, Walter; BALDINI, Isis et al. Walter Zanini e a formação de um sistema de arte contemporânea no Brasil. Estudos Avançados, v. 32, no 93, pp. 307-329, 2018. Disponível em: <http://www.scielo.br/pdf/ea/v32n93/o103-4014-ea-32-93-0307 .pdf>. Acesso em: 29 ago. 2018.

ZILIO, Carlos; TORRES, Fernanda Lopes; TELLES, Martha. A formação de um pensamento contemporâneo de arte no Brasil dos anos 1970: depoimento de Carlos Zilio. Concinnitas, v. 1, $\mathrm{n}^{\mathrm{0}} 24$, jul. 2014. Disponível em: <http://www.epublicacoes .uerj.br/index.php/concinnitas/article/view/13266/10 165>. Acesso em: 18 dez. 2017.

\section{Vídeos}

\#32bienal (Ativação de obra) Jorge Menna Barreto: Restauro. Youtube, 29 nov. 2016. Disponível em: <https://youtu.be/IXvj_xoqs7U>. Acesso em: 28 ago. 2017.

Julio Plaza, o poético e o político. Youtube, 13 jun. 2013 Disponível em: <https://youtu .be/bOhsAjTBhBM>. Acesso em: 10 nov. 2016.

ZAMBONI, Silvio. Entrevista com Silvio Zamboni - Parte 1. Entrevista concedida a Ana Beatriz Barroso. Youtube, 7 set. 2011. Disponível em: <https://youtu.be/jSc1IIt4w Og>. Acesso em: 27 jan. 2016.

\section{Websites}

BASBAUM, Ricardo. Would you like to participate in an artistic experience? (Site do projeto). Disponível em: <http://www.nbp.pro.br>. Acesso em: 16 dez. 2015.

CAPES - COORDENAÇÃO DE APERFEIÇOAMENTO DE PESSOAL DE NÍVEL. Resultado da Avaliação Quadrienal 2017. Disponível em: < http://avaliacao quadrienal.capes.gov.br/resultado-da-avaliacao-quadrienal-2017-2>. Acesso em: 11 jun. 2018.

ELKINS, James. Artists with PhDs. Disponível em: <http://www.jameselkins.com /yy>. Acesso em: 10 jan. 2018. 
FALCON. Our Story. Disponível em: <https://www.falconenamelware.com/pages/ourstory >. Acesso em: 4 ago. 2018.

JORGE MENNA BARRETO (Portfólio do artista). Disponível em: < http://cargo collective.com/jorgemennabarreto >. Acesso em: 16 dez. 2015.

PLATAFORMA SUCUPIRA. Cursos avaliados e reconhecidos - Artes. Disponível em: <https://sucupira.capes.gov.br/sucupira/public/consultas/coleta/programa/quan titativos/quantitativoAreaConhecimento.jsf?areaAvaliacao=11>. Acesso em: 4 ago. 2018.

REPROJETANDO-BH. Disponível em: <https://reprojetandobh.wordpress.com>. Acesso em: 12 nov. 2017. 
325 
OBRA DE RESISTÊNCIA 